\title{
De geinfecteerde abdominale vaatprothese : een inventarisatie
}

Citation for published version (APA):

Barwegen, M. G. M. H. (1998). De geinfecteerde abdominale vaatprothese : een inventarisatie. [Doctoral Thesis, Maastricht University]. Universiteit Maastricht. https://doi.org/10.26481/dis.19980924mb

Document status and date:

Published: 01/01/1998

DOI:

10.26481/dis.19980924mb

Document Version:

Publisher's PDF, also known as Version of record

\section{Please check the document version of this publication:}

- A submitted manuscript is the version of the article upon submission and before peer-review. There can be important differences between the submitted version and the official published version of record.

People interested in the research are advised to contact the author for the final version of the publication, or visit the DOI to the publisher's website.

- The final author version and the galley proof are versions of the publication after peer review.

- The final published version features the final layout of the paper including the volume, issue and page numbers.

Link to publication

\footnotetext{
General rights rights.

- You may freely distribute the URL identifying the publication in the public portal. please follow below link for the End User Agreement:

www.umlib.nl/taverne-license

Take down policy

If you believe that this document breaches copyright please contact us at:

repository@maastrichtuniversity.nl

providing details and we will investigate your claim.
}

Copyright and moral rights for the publications made accessible in the public portal are retained by the authors and/or other copyright owners and it is a condition of accessing publications that users recognise and abide by the legal requirements associated with these

- Users may download and print one copy of any publication from the public portal for the purpose of private study or research.

- You may not further distribute the material or use it for any profit-making activity or commercial gain

If the publication is distributed under the terms of Article $25 \mathrm{fa}$ of the Dutch Copyright Act, indicated by the "Taverne" license above, 
De Geïnfecteerde Abdominale Vaatprothese 
O M.G.M.H. Barwegen, Marastricht 1998, Nederland ISBN $90-9011966-3$

onslag: Zebra fotosudio's B.V. Venlo wormgeving en druk: Datawyse / Universitaire Pers Malastricht 


\title{
De Geïnfecteerde Abdominale Vaatprothese
}

\author{
Een inventarisatie
}

\section{PROEFSCHRIFT}

ter verkrijging van de graad van doctor aan de Universiteit Maastricht, op gezag van de Rector Magnificus, Prof. dr. A.C. Nieuwenhuizen Kruseman, volgens her besluit van her College van Decanen in het openbaar te verdedigen op donderdag 24 september 1998 om 16.00 uur door M.G.M.H. Barwegen 
Promotor

Prof.dr. P.J.E.H.M Kitslaar

Beoordelingscommissie

Profdr. J.M.A. wan Engelshowen

Prof.dr. J.H. van Bockel (Rijksuniversiteir Leiden)

Prof.dr. C.A. Bruggeman

Prof.dr. R.W. Stockbrigger 


\section{Inhoudsopgave}

1 INLEIDING EN VRAAGSTELLING 11

1.1. Inleiding 11

1.2 Vragstelling 11

2. LITERATUURONDERZOEK 13

2.1 Systematiek wan het literatuuronderzoek 13

2.1.1 Definities 15

2.1.2 Patiëntenselectie in de literatuur 16

$\begin{array}{ll}2.1 .3 \quad \text { Historisch literatumoverzicht } & 17\end{array}$

$\begin{array}{lll}2.1 .4 & \text { Recente literatuuranalyse } & 18\end{array}$

2.2 Incidentie van prothese-infecties 20

2.3 Pathogenese 21

2.3.1 Deprothese 22

2.3.2 Interactie tussen gastheer en prothese $\quad 22$

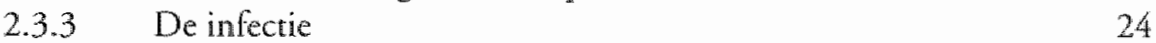

2.3.4 Micro-organismen 25

2.3.5 Antibiotische profylaxe 27

2.4 Risicofactoren voor prothese-infectie 28

2.4.1 De inhoud van het aneurysma 28

2.4.2 De arteriele waatwand 30

2.4.3 De liesdissectie 31

2.4.4 Re-operaties $\quad 33$

2.4.5 Hostile abdomen 33

2.4.6 Urgentie $\quad 34$

2.4.7 Additionele operaties 34

2.4.8 Andere peri- en peroperatieve problemen 36

2.4.9 Naadaneurysma"s 37

$2.5 \quad K$ Klinische presentatie 38

2.5.1 Tijdstip van presentatic 38

2.5.2 Symptomatologie 39

2.6 Diagnostiek 40

2.6.1 Anaromische beeldvorming 41

2.6.2 Funktionele beeldvorming 43

2.6.3 Endoscopie 44

2.6.4 Chirurgische exploratie 45

2.7 Behandeling 45

2.7.1 Behandelingsprincipes 45

2.7.2 Patiëntenselectie en behandeling 47 
2.7.3 Radicale behandeling $\quad 50$

2.7.4 Niet radicale behandeling 51

2.7.5 Autologe behandeling 53

2.7.6 'In situ' behandeling 55

2.7.7 sluiten van de aorta 57

$\begin{array}{lll}2.7 .8 & \text { Revascularisatie } & 57\end{array}$

2.7.8.1-Geen revascularisatie $\quad 58$

2.7.8.2 - Autologe revascularisatie $\quad 58$

2.7 .8 .3 - "In situ' revascularisatie 58

2.7.8.4 - Extra-anatomische revascularisatie $\quad 58$

2.7.8.5 - Timing van de revascularisatie 59

2.8 Resultaten van de behandeling 60

2.8.1 Vroege resultaten 61

2.8.1.1 - Operatiemortaliteit 61

2.8 .1 .2 - peri-operatieve amputaties $\quad 62$

2.8.1.3 -peri-operatieve aortastompinsuffaciëntie 62

2.8.2 Late resultaten $\quad 63$

2.8.2.1 - Mortaliteit 63

2.8.2.2 -Insufficièntie van de aortastomp 64

2.8.2.3 - Amputaties 64

2.8.2.4 - thrombose van de extra-anatomische bypass 65

2.8.2.5 - Infectie van de extra-anatomische bypass 65

2.8.2.6 - Cumulatieve lange termijn morbiditeit 65

2.8.2.7 - Persisteren van de infecrie na niet radicale behavdeling 66

3 MATERIAAL EN METHODEN 67

$\begin{array}{lll}3.1 & \text { Patiënten } & 67\end{array}$

3.2 Verzameling van de gegevens 68

3.3 De onderzochte variabelen $\quad 69$

3.3.1 De primaire operatie 69

$\begin{array}{lll}3.3 .1 .1 & \text { Voorgescbiedenis } & 70\end{array}$

3.3.1.2 - Indicatie $\quad 70$

$\begin{array}{ll}3.3 .1 .3-\text { De operatie } & 70\end{array}$

3.3.1.4 - Additionele operaties $\quad 71$

3.3.1.5 - Peri-operatieve complicaties 71

$\begin{array}{lll}3.3 .1 .6-\text { Microbiologie } & 71\end{array}$

$\begin{array}{lll}3.3 .2 & \text { Het interval } & 71\end{array}$

3.3.2.1 - Postoperatieve infecties $\quad 72$

$\begin{array}{lll}3.3 .2 .2-R e i n t e r v e n t i e s & 73\end{array}$

3.3.3 De infecrie van de abdominale vaatprothese 74

3.3.3.1 - Klinische presentatie $\quad 74$

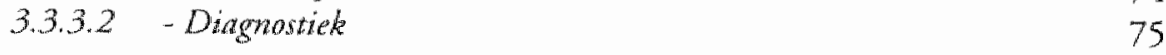


$\begin{array}{lll}\text { 3.3.4 Behandeling van de infectie } & 77\end{array}$

$\begin{array}{lll}3.3 .4 .1 & \text { - Urgentie } & 77\end{array}$

$\begin{array}{lll}3.3 .4 .2 & - \text { Bevindingen bij operatie } & 77\end{array}$

$\begin{array}{lll}3.3 .4 .3 & \text { - Protheseverwijdering } & 78\end{array}$

3.3.4.4 - Behandeling van de aorta $\quad 78$

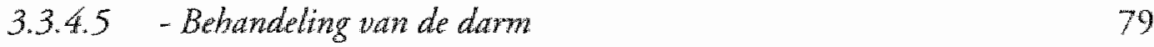

$\begin{array}{lll}3.3 .4 .6-R e v a s c u l a r i s a t i e & 79\end{array}$

3.3.4.7 - Micrabiologie $\quad 80$

$\begin{array}{lll}3.3 .5 & \text { Resultaten } & 80\end{array}$

3.3.5.1 - Classificatie $\quad 80$

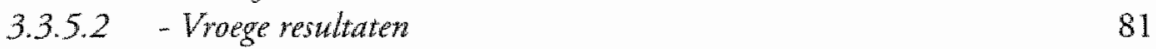

3.3.5.3 - Late resultaten $\quad 82$

$\begin{array}{lll}3.4 & \text { Data analyse } & 82\end{array}$

4 UITKOMSTEN VAN HET ONDERZOEK 83

4.1 De primaire operatie 83

4.1.1 voorgeschiedenis $\quad 83$

4.1.1.1 - Comorbiditeit

4.1.1.2 - Voorafgaande vaatoperaties 83

4.1.1.3 - Recente abdominale operaties $\quad 84$

4.1.2 Indicatie $\quad 84$

4.1.3 De operatie 84

4.1.3.1 - Antibiotische profylaxe 84

4.1.3.2 - Heparinisatie $\quad 85$

4.1.3.3 - De prothese $\quad 85$

4.1.3.4 - Prothesebedekking $\quad 86$

4.1.3.5 - Drains 86

4.1.3.6 - Duur van de operatie $\quad 86$

4.1.4 Additionele operaties 86

$\begin{array}{lll}4.1 .5 & \text { Complicaties } & 87\end{array}$

$\begin{array}{ll}\text { 4.1.6 Microbiologie } & 88\end{array}$

4.2 Het interval 88

4.2.1 Vroege septische complicaties $\quad 88$

4.2.1.1 - Wondinfecties na de primaire operatie 88

4.2.1.2 - Andere post-operatieve infecties na de primative operatie $\quad 89$

4.2.2 Vroege reïnterventies 91

4.2.2.1 - De vroege reïnterventies wegens infectieuze complicaties 91

4.2.2.2 - Microbiologisch onderzoek bij de vroege septische complicaties 92

4.2.2.3 - De vroege reinterventies wegens bloedingscomplicaties 92

4.2.2.4 - De vroege reinterventies wegens sischemische complicaties 93

4.2.2.5 - De vroege amputaties 93 
4.2.2.6 - De wroege reïnterventies wegens aandoeningen van de tractus digestivus

4.2.2.7 - De troege reinterventies wegens adndoeningen van de tractus mrogenitalis

4.2.2.8 - De vroege reinterventies wegens adndoeningen van de tractus respiratorizus

4.2.2.9 - De vraege rë̈nterventies wegens andere aandoeningens 94

4.2.3 De reinterventies in her interval 96

4.2.3.1 - De reinterventies wegens infectienze complicaties in bet interval 96

4.2.3.2 - De reinterventies wegens bloedingscomplicaties in het interval 98

4.2.3.3 - De reinterventies wegens ischemische complicaties in bet interval

4.2.3.4 - De amputaties in het interval

4.2.3.5 - De reinterventies wegens adandoeningen wan de tractus digestivus in het interval

4.2.3.6 - De reinterventies wegens aandoeningen van de tractus urogenitalis in het interval

4.2.3.7 - De reinterventies wegens maligne aandoeningen in bet interval $\quad 100$

4.2.3.8 - De reinterventies wegens diverse aandoeningen

$\begin{array}{ll}4.3 & \text { De infectie van de abdominale vaatprothese } \\ 4.302\end{array}$

4.3.1 Duur van het interval

102

4.3.2 Klinische presentatie

$\begin{array}{ll}4.3 .3 & \text { Overige symptomatologie } \\ 4.3 .1 & 105\end{array}$

4.3.3.1 - Malaiseklachten

$\begin{array}{lll}\text { 4.3.3.2 - Lichaamstemperatur } & 106\end{array}$

4.3.3.3-Sepsis

106

4.3.3.4 - Septische embolie $\quad 106$

$\begin{array}{lll}\text { 4.3.3.5 - Bezinkingssnelbeid van de erythrocyten } & 106\end{array}$

$\begin{array}{lll}4.3 .3 .6-\text { leucocyten } & 107\end{array}$

$\begin{array}{ll}4.3 .4 \text { Naadaneurysma's } & 108\end{array}$

$\begin{array}{ll}4.3 .5 & \text { Diagnostiek } \\ 4.5 .1 & 108\end{array}$

$\begin{array}{lll}4.3 .5 .1-E c h o g r a f t e & 109\end{array}$

$\begin{array}{lll}4.3 .5 .2 & \text { Computertomografie } & 109\end{array}$

$\begin{array}{lll}4.3 .5 .3-S i n o g r a f i e & 110\end{array}$

$\begin{array}{lll}4.3 .5 .4-1 \text { Tsotopenscintigrafie } & 110\end{array}$

4.3.5.5 - Magnetischresonantie onderzoek 111

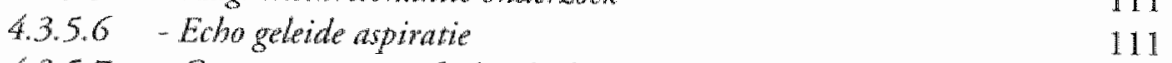

4.3.5.7 - Computertomografisch geleide aspiratie 111

4.3.5.8 - Gastro-duodenoscopie 111

$\begin{array}{lll}4.3 .5 .9-\text { Colonoscopie } & 112\end{array}$

$\begin{array}{ll}43.5 .10-\text { Angiografie } & 112\end{array}$ 
4.3.6 Microbiologie 113

4.4 De behandeling 115

4.4.1 Inleiding 115

4.4.1.1 - Tijdsduur tussen diagnose en behandeling 115

4.4.1.2 - Urgentie 11.6

$\begin{array}{ll}4.4 .2 & \text { Indeling van de infecries } \\ & 116\end{array}$

4.4.3 Indeling van de behandeling 117

$\begin{array}{ll}\text { 4.4.4 Bevindingen bij operatic } & 119\end{array}$

4.4.4.1 -Ingroei van de prothese 119

4.4.4.2 - lokalisatie van de arto-enterale fostel 119

$\begin{array}{ll}4.4 .5 & \text { Behandeling van de aorta } \\ & 120\end{array}$

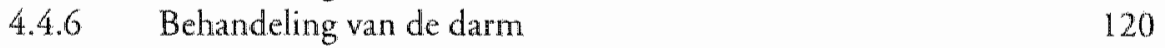

$\begin{array}{lll}4.4 .7 & \text { Revascularisatie } & 122\end{array}$

$\begin{array}{ll}4.4 .8 \text { Wondbehandeling } & 125\end{array}$

4.4.9 Microbiologie 126

4.5 De resultaten van de behandeling 1.26

4.5.1 Inleiding 126

$\begin{array}{ll}4.5 .2 & \text { Verpleegduur en beademing } \\ & 128\end{array}$

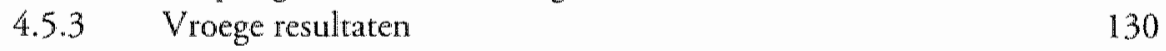

4.5.3.1 - Complicaties van de vitale organen 130

4.5.3.2 - Bloedingscomplicaties 131

4.5.3.3 - Seprische complicaties 133

4.5.3.4 - Complicaties van de extra-anatomische bypass 134

4.5.3.5 - Amputaties 1.35

$\begin{array}{lll}\text { 4.5.3.6 - Ischemische colitis } & 1.35\end{array}$

4.5.3.7 - Hospitalmortaliteit $\quad 135$

4.5.3.8 - Doodsoorzaken 136

4.5.4 Late resultaten 1.38

4.5.4.1 - Late mortaliteit $\quad 138$

4.5 .4 .2 - Late morbiditeit $\quad 140$

5 DISCUSSIE 1.43

5.1 Representativiteit 143

5.2 De primaire operatie 144

5.3 Het interval 146

5.4 De infectie 148

5.4.1 Tijdstip van manifestatie van de infectie 148

$\begin{array}{lll}5.4 .2 & \text { Presentatievan de infectie } & 148\end{array}$

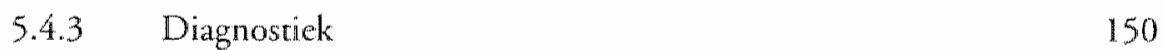

5.4.4 Behandeling 153

$\begin{array}{ll}5.4 .5 & \text { Vroege resultaten } \\ 5.46 & 154\end{array}$

5.4.6 Late resultaten 156 
5.4.7 Microbiologie 158

6 CONCLUSIE 161

7 SAMENVATTING 163

8 SUMMARY 165

9 APPENDIX 167

9.1 Microbiologie 167

9.2 Antibiotica 168

9.3 Literatuuroverzicht 169

10 BIBLIOGRAFIE 175

CURRICULUM VITAE 193

DANKWOORD 194 


\section{MOMPDSTH}

\section{Inleiding en vraagstelling}

\subsection{INLEIDING}

Ter behandeling van zowel oblitererend als dilaterend arterieel vaatlijden worden sedert de jaren vijftig abdominale vaatprothesen geümplanteerd. Infecties zijn inherent aan elke chirurgische ingreep en komen dus ook voor bij de implantatie van vaatprothesen.

Vanaf het begin van jaren zestig wordt gediscussieerd over de behandeling van deze infecties met als hoofdthema her al dan niet verwijderen van de prothese. ${ }^{25,46,154}$ Tot op heden zijn de akten daarover niet gesloten. Hoewel in Nederland momenteel jaarlijks meer dan 4000 aneurysma's van de abdominale aorta operatief worden behandeld ${ }^{2(6)}$ en daarnaast nog een groot aantal abdominale vaatprothesen worden gebruikt voor reconstructieve doeleinden, is in Nederland maar weinig over de behandeling van infecties van (abdominale) vaatprothesen gepubliceerd, ${ }^{170,332,343}$ en de discussie over wat de juiste behandeling zou moeten zijn, is nog nauwelijks van de grond gekomen.

Als de behandeling van infecties van abdominale vaatprothesen wit gehele of gedeeltelijke verwijdering van de prothese bestaat, moet na verwijdering van de prothese, meestal de doorbloeding van de onderste lichaamshelft worden hersteld of verbeterd. In het geval, dat als gevolg of als oortaak van de infectie, een verbinding met het maag-darmkanaal bestaat, moet het betrokken deel van de darm worden gesloten of verwijderd. Deze behandelingen wergen én of meerdere grote operaties met een aanzienlijk risico voor het leven of het behoud van de onderste extremireit(en) van de patiënt.

\subsection{VRAAGSTELLING}

Dit proefschrift beoogt een inventarisatie te zijn van de stand van zaken omtrent de diagnostiek en behandeling van de geinfecteerde abdominale vaatprothese met de volgende vraagstelling:

- zijn er oorzaken aan te wijzen woor het ontstaan van infecties van abdominale vaatprothesen en zijn deze te beïnvloeden? 
- wat zijn de (klinische) verschijnselen waarop de diagnose prothese-infectie kan worden gesteld?

- welke diagnostisch hulpmiddelen zijn bruikbaar bij het stellen van de diagnose?

- hoe worden de infecties in het onderzochte patiëntenmateriaal behandeld?

- wat waren de resultaten van de behandeling en hoe verhouden die zich ten opzichte van reeds gepubliceerde resultaten?

- is er een richtlijn op te stellen voor diagnostiek en behandeling van deze aandoening?

Ter beantwoording van deze vragen werden retrospectief de gegevens verzameld van patiënten uit 11 Nederlandse universitaire en opleidingsziekenhuizen die werden behandeld voor cen infectie van een abdominale vaatprothese vanaf de operatie waarbij de prothese werd ingebracht (de primaire operatie). Deze operatie zelf en de daaropvolgende periode tot de eerste manifestatie van de infectie (het interval) en de wijze warop de infectie tot uiting kwam alsmede de verrichte diagnostick en de behandeling werden geanalyseerd. De uitkomsten van her onderzoek werden vergeleken mer gegevens uit de bestaande literatuur. 


\section{Literatuuronderzoek}

\subsection{SYSTEMATIEK VAN HET LITERATUURONDERZOEK}

\subsubsection{DEFINITIES}

In her klinisch spraakgebruik en in publicaties worden in verband met infecries van her vasculaire systeem, verschillende begrippen gebruikt die soms verwarrend zijn en die van elkaar dienen te worden onderscheiden.

Door Sir William Osler werd in 1885 de term 'mycotic aneurysm' geïntroduceerd waarmee hij een aneurysma ten gevolge van een primaire bacteriële infectie van bloedvaten, leidend tot aneurysmavorming, bedoelde.

Met abdominale vaatprothese wordt in deze studies bedoeld de buisprothese in de aorta en de aorto-bi-iliacale en de aortobifemorale prothesen, of combinaties daarvan, dus niet de unilaterale prothesen. In de literatuur worden, hoewel dit niet overal met zekerheid is vast te stellen, unilaterale aorto-iliacale of aortofemorale prothesen soms ook tot de abdominale vaatprothesen gerekend. $67,230,261,265,313$, Onder perigraft infectie (PGI) wordt verstaan een infectie rondom een prothese. Een primaire aorto-enterale fistel (AEF) is een verbinding tussen de aorta en het darmlumen die ontstaat ten gevolge van een ontstekingsproces in de darm of een proces in de aorta, meestal cen aneurysma zonder dat er aan de aorta geopereerd is. Deze vorm van aorto-enterale fisteling werd voor het eerst beschreven door Sir Astley Cooper in $1825 \mathrm{en}$ is zeldzaam. In een literatuuronderzoek tor 1984 door Sweeney werden in total niet meer dan tweehonderd gevallen beschreven ${ }^{322}$ en wereldwijd 54 in de laatste 10 jaar. ${ }^{351}$

Een secundaire aorto-enterale fistel ontstaat als complicatie na een operatie aan de abdominale aorta, al dan nier met gebruik van een prothese.

Omdat primaire aorto-enterale fistels veel zeldzamer zijn wordt bij de beschrijving van de secundaire fistels de toevoeging 'secundair' vaak weggelaten. Het voorvoegsel primair wordt soms weer toegevoegd aan de term prothese-infectie om aan te geven dat het gaat om een perigraft infectie zonder aorto-enterale fistel. ${ }^{265}$

Een aorto-enterale erosie is een directe verbinding tussen een deel van de vaatprothese gelokaliseerd tussen de anastomosen en het lumen van de tractus digesti- 
vus. ${ }^{3 \%}$ De aorto-ureterale en de aorrowesicale fistels zijn veel zeldzamer en worden meestal ook tot de groep der aorto-enterale fistels gerekend.

Het verschil tussen fistel en erosie berust op een theoretisch verschil in etiologie. De infecticuze theorie gaat erwan uit dat ten gevolge van de infectie ofwel een desintegratie van de anastomose en daardoor erosie van de nabijheid gelegen darm ontstaat, of dat de infectie ter plaatse van adhesie van de darm op de prothesemantel een crosie van de darm veroorzakt. ${ }^{43}$ De mechanische theorie gaar ervan uit dat de pulsatiele kuacht van de prothese erosie van de darm veroorzaakt en dat contaminatic optreedt nadar de prothese in het darmlumen is gepenetreend. ${ }^{38} \mathrm{Her}$ verschil tussen aorto-enterale erosies en fistels is klinisch nog minder duidelijk en in de meeste publicaties wordt dit verschil dan ook niet gemaakt. Indien men uirgaat van de mechanische eciologie zou het bij een erosie theoretisch mogelijk zijn dat sllechts een deel van de prothese is geinfecteerd, hergeen een lokale behandeling zou rechtvardigen. Hoewel her duidelijk is dat bij aorto-enterale fistels en erosies in elk geval ter plaatse van de fistel of de erosie een infectie bestat en de behandeling van deze complicatie in principe niet anders is dan bij geïfecteerde prothesen, worden aorto-enterale fistels en erosies in sommige publicaries niet tot de prothese-infectie in engere $z$ in gerekend. $18,19,38,178,237,247,248,340$

Deze theoretische achtergronden buiten beschouwing latend, zijn de aorto-enterale fistel en de erosie niet anders dan, al dan niet gelokaliseerde, vormen wan prothese-infectie die ten gevolge van de verbinding met de tractus digestivus een aantal specifieke kenmerken hebben ten opzichte van een infectie zonder fistel.

Een nauwkeurige omschrijving van de bevindingen die bewijzend zijn voor het bestaan van een infectie van een vatprothese is niet bekend. De lalassifikatie van Szilagyi uit 1972 omvat een indeling van wondinfecties op grond van de uitbreiding in de diepte, warbij graad III, per definitie, de situatie weergeeft waarin de wondinfectie zich zover in de diepte heeft uitgebreid dat de prothese in thet geinfecteerde gebied ligr. Hij kwam tot deze empirische indeling ondar wondinfecties van de beide cerste graden geen anleiding gaven tot problemen. ${ }^{324}$ Bunt (1983) maakte een indeling in (peri)graft infectie, 'graft-enteric erosion', "graft-enteric fistula' en "aortic scump sepsis" zonder deze begrippen nader te definièren. De enige omschrijving voor infectie dic hil geeft is 'substantiated by positive graft matrix culture". 3\% Samson geeft een derde klassifikatie van infecties voor perifere ("non-aortic') prothesen, waarbij de eerste 2 groepen overeenkomen met graad I en II van Szilagy. Groep III omvar infecties van de body van de prothese, maar geen anastomose(n). Groep IV betreft infecties rond een onbedekte anastomose zònder bacterièmie of bloeding en groep $\mathrm{V}$ bevat de infecties rond een onbedekte anastomose met bacreriemie en/of bloeding. ${ }^{278}$ 
Deze drie klassificaties omvatten omschrijvingen van de diepte van wondinfecties (Szilagyi), bevindingen bij operatie (Bunt) of een combinatic daarvan, uirgebreid met lokalisatie en symptomen.(Samson)

De microbiologische definirie van infectie luidt: de toestand na contaminatie en kolonisatie, waarbij een ontstekingsreactie ontstaat die zich op zijn minst kenmerkt door een veranderde fysiologie al dan niet met (sub) klinische werschijnselen. ${ }^{347}$ Omdat een moderne prothese normaliter ingroeit (zie 2.3.2) is niet ingroeien wan de prothese te beschouwen als een verandering in de fysiologie. Van infecrie van een prothese kan worden gesproken als de prothese niet ingegroeid is en omgeven is door vocht of débris en in het grampreparaat micro-organismen en leucocyten worden gevonden. ${ }^{265}$ Het definitieve bewijs voor het bestaan van een prothese infecrie bestaat uir het aantonen van pus (bacterièn én leucocyten) rondom enig deel van de prothese en een minimum eis voor het stellen wan de diagnose is een losliggende, niet ingegroeide prothese. ${ }^{186,265}$

Bij een patiënt zonder algemene of lokale tekenen van infecrie bij een niet ingegroeide prothese, maar zonder aantoonbare bacterièn en/of leucocyten kan twijfel ontstaan of er sprake is van een infectie van de prothese. ${ }^{189,309}$ Dit probleem doet zich het meest woor bij een lokaal loslliggende prothese in een naadaneurysma.

Het niet kunnen aantonen van bacteriën bij een losliggende prothese hoeft niet te betekenen dat ze er niet zijn. S. epidermidis is een van de meest voorkomende organismen bij infecties van geïmplanteerde biomaterialen, ${ }^{344,347}$ zoals hartklepprothesen, ${ }^{303}$ heupprothesen, ${ }^{48.163} \mathrm{CSF}$-shunts ${ }^{287}$ en vaatprothesen. ${ }^{11,17,200,291.362} S$. epidermidis en andere coagulase negatieve staphylococcen (CNS), kunnen zich jaren in de biofilm rondom een vaatprothese bevinden zonder andere verschijnselen dan niet ingroeien van de prothese en de aanwezigheid van leucocyten Een gram preparaat durante operationem levert soms alleen leucocyten op. ${ }^{12,21}$ Zonder speciale maatregelen is het niet altijd mogelijk om de aanwezigheid van S. epidermidis ook in een kweek aan te tonen. Kweken op meerdere media en ultrasone behandeling van de prothese om de bacteriën uit de biofilm los te maken, is dan noodzakelijk om de bacteriën aan te tonen. ${ }^{10,11,185,233,347}$

Het vinden van bacteriën in een grampreparaat alléén, is te weinig om met zekerheid wan een infectie te kunnen spreken, omdat in een hoog percentage contaminatie van prothesen kan worden aangetoond, bij anastomoseaneurysma's zelfs tot $90 \%$, zonder dat er sprake is van infectie en na volledige resectie van een naadaneurysma en prothese interpositie, ook geen infectie hoeft te ontstaan. ${ }^{70,160,291,362}$ Aantoonbaar is dat bij secundaire vasculaire procedures in hetzelfde operatiegebied significant meer $S$, epidermidis wordt gevonden en eveneens significant meer infecties voorkomen. ${ }^{21,85,200}$ Mogelijk speelt hier de aanwezigheid van bacteriën in de eigen arterie van de patiënr een rol, waarvan behalve in de genoemde studies meestal geen microbiologisch onderzoek wordt verricht. ${ }^{20.160 .291}$ 
In een serie late prothese-infecties zonder septische verschijnselen, die zich manifesteren met een sinus in de lies, valse aneurysma's of infiltraat in de lies, waarbij de prothese niet ingegroeid was en in het gram preparaat alléén polymorfonucleaire leucocyten en geen bacteriën aantoonbaar waren, werd in $80 \%$ van de gevallen $S$ epidermidis gevonden. "In een andere series met een identiek klinisch beeld zonder sepsis en zonder pus rond de prothese werden goede resultaten bereikt met in situ' reconstructie terwijl de kweken negatief bleven. ${ }^{152,296,309}$ Mogelijk spelen bacterièn met de eigenschappen van $S$ epidermidis (bv S. Warneri) ${ }^{309}$ een rol bij de niet ingegroeide prothese zonder pus en zonder sepsis.

Een niet ingegroeide prothese en polymorfonucleaire leucocyten in het grampreparaat vormen dus de belangrijkste criteria en minimum eisen voor het stellen wan de diagnose prothese-infectie.

\subsubsection{PATIËNTENSELECTIE IN DE LTTERATUUR}

In publicaties over de behandeling van prothese-infecties wordt, hoewel de selectiecriteria niet altijd even duidelijk zijn, vrijwel altijd vermeld dat het gaat om geselecteerde patiëntenpopulaties. Een zekere vorm van patiëntenselectie is bij retrospectief klinisch onderzoek onvermijdelijk, doch voor vergelijking en beoordeling van de inhoud van de verschillende publicaties moet rekening worden gehouden met soms zeer uiteenlopende selectiecriteria. Selectie op basis van de diagnose PGI of AEF, evenals de selectic op basis van de lokalisatie van de prothese in de buik is aangegeven in het literatuuroverzicht. (zic appendix 9.3) Er zijn slechts enkele auteurs die alle patiënten met een abdominale vaatprothese gedurende een bepaalde periode hebben gevolgd, waarbij mogelijk in die periode nict alle infecties tot uiting komen. ${ }^{197,207}$. Sommige auteurs volgen alleen de patiënten met een infectie uit hun eigen pariëntenmateriaal, waarbij de vraag is of alle infecties bekend zijn. ${ }^{143}$ Herzelfde geldt, mogelijk in nog sterkere mate, in multicenter studies. ${ }^{19,272}$ De meeste auteurs beschrijven de infecties die zij hebben gezien of behandeld in een bepaalde periode, $50,2,38,279,296,339$ of alleen patiënten die zij hebben geopereerd in verband mer de infectie. ${ }^{18,132}$ Bandyk beschrijft alleen de resultaten van de infecries veroorzaakt door staphylococcus epidermidis " en Malone alleen patiënten met gedocumenteerde vaatwandkweken van de primaire operatie. ${ }^{204}$ Kuestner (1995) neemt alleen patiënten op die voldoen aan de voorwaarden van haar behandelingsprotocol. ${ }^{178}$ Bunt (1993) beschrijft alleen zijn persoonlijke ervaring. ${ }^{41}$ Bacourr (1992) selecteert de patiënten met een axillofemorale bypass, waarbij ook patiënten met een primaire infectie in de serie zijn opgenomen.? Waar meerdere behandelingen naast elkaar werden toegepast wordt niet altijd vermeld op basis waarvan de keuze is gemaakt of is de omschrijwing niet eenduidig. ${ }^{136}$ 
In 1912 werd door de latere Nobelprijswinnaar Alexis Carrel aangetoond dat het mogelijk was door kunststofbuizen, geimplanteerd in het arterièle varsysteem, gedurende langere rijd de circulatie in stand te houden. De klinische toepassing lier op zich wachten tordat Voorhees en Blakemore in 1952 de fabrieksmatig geproduceerde kunststofprothese "Vinyon-" $N$ " introduceerden. ${ }^{305}$ Daarna werden verschillende andere kunststof vaatprothesen gebruikt wan materialen als Arlon, $\mathrm{Ny}_{\mathrm{y}}$ lon en Teflon. Uiteindelijk werden de Dacronprothesen geïntroduceerd, die heden ten dage, zij her met enige veranderingen in de uirvoering, nog steeds worden gebruikt.

In de loop van de zestiger en zeventiger jaren ontwikkelde de aneurysmachirurgie zich snel en nam ook de chirurgie voor obstruerend vaatlijden een enorme vlucht. Mer het gebruik van kunststofmaterialen kwamen ook de daaraan gerelateerde complicaties. Er zijn vele complicaties beschreven, waaronder (recidief-) afsluitingen, naadaneurysma's, degeneratieve afwijkingen van de prothese zelf en infecties. De behandeling van de infecties van de arteriele vaatprothesen bleef tot op heden, meer dan dertig faar later, een probleem waarvoor geen eenduidige behandeling bestaat.

In 1962 postuleerde Javid, dat de geïnfecteerde vaatprothese de infectie onderhoudt en derhalve verwijderd dient te worden. ${ }^{154}$ Fry en Lindenauer herhaalden dat in 1967." ${ }^{11}$ Anderen, zoals Carter en Whelan in 1963 en Najafi in 1968 waren voorstanders van behandeling zonder verwijdering van de prothese. 49,226 In 1977 brak Crawford een lans voor het gestadieerd behandelen om ischemische schade te voorkomen ${ }^{65}$ en in 1979 propageerde Ehrenfeld de autologe reconstructie na protheseverwijdering. ${ }^{89}$ Een van de vroege verslagen van de behandeling van een abdominale prothese-infectie is de publicatie van Blaisdell die in 1961 een patiënt behandelde door middel van verwijderen van de prothese, sluiren van de aortastomp met catgut en aanleggen van een thoracofemorale bypass. ${ }^{25}$ De extra-anatomische revascularisatiemethoden ontstonden in dezelfde periode. In 1962 beschreven Blaisdell en Hall de axillo-femorale bypass ${ }^{25}$ en in 1963 beschreven Shaw en Baue de bypass door her foramen obturatorium. ${ }^{297}$

De secundaire aorto-enterale fistel werd voor het eerst beschreven door Brock in 1953. Het betrof een fistel tussen het duodenum en een vals aneurysma op de naad tussen een homograft van de aorta en de linker arteria iliaca communis. ${ }^{32}$ Drie jaar later beschreef Claytor voor het eerst een fistel ten gevolge van een operatie waarbij een nylon bifurcatieprothese werd gebruikt. ${ }^{59}$

Begin zestiger jaren verschenen de vroegste publicaties over infecties van vaatprothesen. ${ }^{25,227}$ Vanaf halverwege de zeventiger jaren werschenen meerdere publicaties, aanvankelijk kleine series berreffend, zowel over prothese-infecries, alsook, hoewel in de minderheid, over aorto-duodenale fistels. 
De grootste serie tot dat moment publiceerde Szilagyi in 1972. ${ }^{324}$ Het betrof 40 patienten met ean prothese-infectie, waarvan 3 in aortowiliacale en 20 in aorto-femorale positit, waarvan er 11 de behandeling overleefden. De eerste samenvattende studic, warin een overzicht wordt gegeven van de publicaties over prothese-infecties, dateert wan 1974. Tot dat moment waren er 178 gevallen wan geinfecteerde watprothesen bekend, waarwan 164 voldoende gedocumenteerd woor een review. Deze serie van Liekweg bevarte 84 patiènten met aorto-illiacale en aortofemorale prothesen en geen aorto-nterale fistels of erosies. ${ }^{193}$

De mortaliteit van de behandeling van geinfecteerde vaatprothesen op het aortofemorale niveau bedroeg in die serie $47.9 \%$. Naarmate de geïfecteerde prothese zich distaler in her arteriële vaatbed bevond daalde de mortaliteit en steeg het amputatiepercentage. De beste resultaten werden verkregen door verwijderen van de prothese gecombineerd mer revascularisatie. Deze studie laar nauwelijks conclusies toe, omdat de verschillende behandelingsmodaliteiten (lokale behandeling met en zonder protheseverwijdering, radicale behandeling met revascularisatie en radicale behandeling met primaire amputatie) ieder slechts geringe aantallen patiënten (maximaal 17) omvatten.

Bunt gaf in cen tweetal overzichtsartikelen in 1983 een soort 'meta-analyse'. over 265 perigraft infecties, 256 aorto-encerale fistels, 34 aorro-enterale erosies en 20 gevallen van "aortic stump sepsis". ${ }^{37.38} \mathrm{Hij}$ stelde vast dat er sedert de publicatie van Liekweg merkwaldig weinig was veranderd. Voor het aorto-iliacale traject gold, dat zonder behandeling, de mortaliteit $100 \%$ bedroeg (2 pat), bij verwijderen van de prothese zonder revascularisatie $33 \%$ (12 pariënten) en met aanleggen van een extra-anatomische bypass $38 \%$. Bij de paciënten die werden behandeld met alleen an tibiorica en drainage bedroeg de mortaliteit $25 \%$ mara de duur van de follow up is niet vermeld.

In 1994 verschenen de eerste monografien over prothese-infecties ${ }^{42,44}$ In standaard werken wordt het probleem van de prothese-infecties en de arto-enterale fistels mar wrij summier besproken. 275

\subsubsection{RECENTE IITERATUUR ANALYSE}

De literatutur vanaf 1980 wordt in een rabellarisch overzicht weergegeven in appendix 9.3. Ten behoeve van dir overzicht werd de literatuur over diagnostiek en behandeling van de abdominale prothese-infecties vanaf 1980 verzameld en ingedeeld op basis van de door de auteur meest verrichre of aanbevolen behandeling. Opgenomen zijn 80 rijdschriftartikelen betreffende un totaal 2079 pariënten, waran er $1619(77.9 \%)$ voldeden an de definitie abdominale vatprothese. Acht artikelen (10\%) bevatcen 'case-histories' of slechts I patiënt die an de definitie voldoer. Door dit hele proefschrift heen wordt regelmarig naar de gegevens in dit overzicht uir de recente literatuur verwezen. Tabel 2.1 geeft een overzicht van 
her maximale, het gemiddelde en het mediane aantal patiënren per publicatie voor het total van alle infecries en onderscheiden naar type infecrie (PGI of AEF).

Tabel 2.1. Overzicht van patienten aan rallen in de 80 gebruikte publicaries vanaf 1980 over diagnostick en behandeling van de geinfecteende abdominale vatprothese (2ie appendix 9.3 )

\begin{tabular}{lcccc}
\hline & totaal & maximal & gemiddeld mediaan \\
\hline aantal patienten & 2079 & 141 & 26.0 & 20.0 \\
abdominale prothese & 1619 & 101 & 16.0 & 20.3 \\
PGI & 931 & 62 & 11.7 & 10.0 \\
AEF* & 665 & 43 & 8.3 & 3.0 \\
\hline
\end{tabular}

*in een publicarie met 23 parièncen is dit niet aangegeven ${ }^{5 *}$

Analyse van de literatuur over geïnfecteerde vaatprothesen stuit op moeilijkheden, omdat aanvankelijk, maar ook nog recent, zich verschillend uirende infecties en verschillend gelokaliseerde en verschillend behandelde infecties zonder onderscheid in één serie worden gepresenteerd, waardoor het niet mogelijk is goede vergelijkingen te maken ${ }^{37,143}$ publicaties omvatten meestal zowel infecties wan unials bilaterale abdominale prothesen, ${ }^{67,189,265.313}$ alsook infecties van perifere en centrale prothesen, ${ }^{37,143,203}$ en soms ook nog infecties van de extra-anatomische bypass. ${ }^{42.80 .339}$ Behalve om prothesen die wegens infectie worden verwijderd gaat her daarnaast aok om prothesen die worden verwijderd wegens aneurysma spuri$\mathrm{um}^{211}$ of thrombose ${ }^{207,229,296}$. Series zijn samengesteld uit perigraft infecties ( $P G I$ 's) èn aorto-enteralle fistels ( $A E F$ 's) of uitsluitend een van beide. Ook worden primaire en secundaire aorto-enterale fistels zonder voldoende onderscheid tezamen besproken.

Verschillende behandelingsmethoden worden door-en na elkatr verricht en vaak

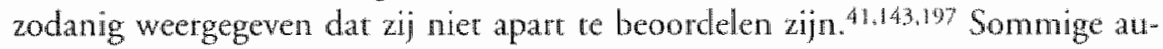
teurs vermelden het totaal resultaat van verschillende behandelingen die zij in een bepaalde periode of bij een geselecteerde patièntenpopulatie toepasten. ${ }^{7,197}$ In de loop van de tachriger jaren werschenen er enkele publicaties van grotere series pariënten waarin duidelijker gedifferentieerd wordt naar lokalisatie, uitingsvorm en behandeling. Linda M Reilly et all publiceerden in 1984 de tot op dat moment grootsre serie met de resultaten uir de kliniek van Ehrenfeld over 92 patiënren. ${ }^{265}$ Daarin wordt een duidelijk onderscheid gemaakt tussen de infecrie rondom de prothese: 'perigraft infections' (PGI) en 'aortoenteric fistula' (AEF). In de serie perigraft infections werden echter ook 8 infecties opgenomen, die buiten het aorto-iliacale of her aorto-femorale traject gelokaliseerd waren, terwijl niet duidelijk wordr of ook unilaterale prothesen zijn opgenomen. De publicatie van 1987 van dezelffe auteurs gaat over 'aortic graft infections' en omvat alleen abdominale prothese-infectics warbij de aorto-enterale fistel ook als infectie wordt beschouwd. ${ }^{26}$ ? 
Zij propageerden radicale protheseverwijdering en stelden dat de beperkt toepasbare autologe revascularisatie de voorkeur verdient boven extra-anatomische revascularisarie. Tevens werd het tijdstip van revascularisarie, vóór of na protheseverwijdering, zoals eerder door Casali, Tumipseed en "Trout was gedaan, opnieuw ter discussie gesteld. $50,3,37.339$

In dezelfde periode verschenen enkele artikelen, warin opnieuw principiële vraagstukken als extra-anatomische versus in situ revascularisatie aan de orde werden gesteld, terwijl de discussie over de behandeling met en zonder protheseverwijdering opnieuw op gang kwam. ${ }^{12,152,353}$

Sommige publicaties zijn uirsluitend gebaseerd op én bepaalde behandeling van de prothese-infecrie, zoals de lokale, de autologe of de 'in situ' behandeling. Het merendeel van de publicaties, met name de grotere series, omvatten in het algemeen de resultaten van patiënten die op verschillende wijzen werden behandeld en waarbij dan wel één methode de voorkeur heeft of het meest wordt toegepast. ${ }^{12.313}$ Daarnaast zijn er nog een aantal overzichtsartikelen waarin alleen een beschouwing of samenvatting wordt gegeven zonder behandelingsresultaten. ${ }^{10,64.170,233,185}$ Met al deze beperkingen rekening houdend is in de genoemde 80 referenties uit appendix 8.3 getracht de wijze warop de behandeling plats vond en de erbij behorende aantallen patiënten te bepalen, alsmede de ermee gepaard gaande operatiemortaliteit, complicaties en overlevingsgegevens.

\section{INCIDENTIE VAN PROTHESE-INFECTIES}

De incidentie van infecries rondom een abdominale vaatprothese is om meerdere redenen moeilijk te achterhalen en wordt in retrospectieve studies geschat op een percentage tussen 0.7 en $6 .{ }^{29,193124,197,236326}$

Redenen waarom de incidencie zo moeilijk is te achterhalen zijn de moeilijkheden bij het stellen van de diagnose, ${ }^{185,247,265}$ het soms zeer lange interval tussen de implantatie van de vaatprothese en de ecrste klinische manifestatie van een infectie, $124,236,365$ het feit dat nier zelden de infectie in een andere kliniek wordt behandeld dan die waar de implantacie plaats vond ${ }^{236,365}$ en de follow-up gegevens maar zelden compleet zijn. ${ }^{236}$

Daarnaast wordt het in veel publicaties niet duidelijk of de opgegeven cijfers betrekking hebben op (thoraco-)abdominaal gelokaliseerde prorhesen of op perifere prothesen of beide. $21,247.257$ Soms is het onduidelijk of de prothese werd ingebracht wegens aneurysmatisch of wegens oblitererend vaatlijden terwiil aorro-enterale erosies of fistels niet altijd als infectie worden meegerekend. ${ }^{37,88,189,143}$ De hoogste percentages prothese-infecties, respectievelijk $7.3 \%$ en $6 \%$, publiceerden Jamieson (1975) en Hoffert (1965) in series die patiënten met zowel perifere
als abdominale vaatprothesen bevatten. ${ }^{148.153}$ 
De serie van Hoffert is samengesteld uit infecties in het aorto-iliaco-femorale traject mer een incidentie van $2.2 \%$ en infecties in het femoropopliteale traject met een incidentie van $12.0 \%$. Jamieson vermeldt een daling van het infecriepercenta ge naar $2.2 \%$ na invoering van antibiotische profylaxe. Szilagyi rapporteerde in 1972 over een serie van 3347, in 20 jaar, geopereerde patiënten. In het aorto-iliacale traject was het infectiepercentage 0.7 . In die 20 jaar leverden de aorto-femorale reconstructies $1.6 \%$ infecties op en de femoro-popliteale reconstructies $3.0 \% .{ }^{324}$ In een tweede publicatie vond Szilagyi (1986) in een serie van 1748 reconstructieve procedures in 30 jaar een infectiepercentage van 1.6\%. ${ }^{326}$ Lorentzen verzamelde gegevens over alle arteriêle reconstructies waarbij prothetisch materiaal werd gebruikt uit Denemarken van 1978 tot en met 1981. Bij afsluiten van het onderzoek in november 1984, dus na een follow up van ongeveer twee en een half jaar, bedroeg het totale infecriepercentage $2.6 \%$. Het infectiepercentage voor aorro-femorale bifurcatieprothesen was $2.3 \%$ in de groep obliteratieve afwijkingen en $5.9 \%$ bij de aneurysma"s. Bij de femoro-popliteale reconstructies ontstonden infecties bij 3.5\%..$^{197}$

O'Hara (1986) vond in een serie uit de Cleveland Clinic van 3652 abdominale reconstructies waarbij een prothese werd gebruikt, in 25 jaar $0.43 \%$ infecties bij operaties waarbij alle anastomosen in de buik konden worden aangelegd en $1.34 \%$ als de lies werd geopend. ${ }^{236} \mathrm{Hij}$ maakt geen onderscheid tussen oblitererend of aneurysmatisch vaatlijden. Edwards (1987) die de aorto-enteralle fistels niet als infectie meetelt vond na 15 jaar in het aorto-femorale traject 0.5 procent infecties en in het aorto-iliacale traject evenals Lorentzen geen infecties. ${ }^{88}$

Voor Nederland zijn maar weinig cijfers beschikbaar. Van den Akker (1992) vond 8 prothese-infecries bij 518 patiënten mer een abdominale vaatprothese (1.54\%) en Bosman registreerde 8 prothese-infecties (1.23\%) bij 647 patiënten, geopereerd voor aneurysmatisch vaatlijden, waarvan 2 binnen 30 dagen. Vier van deze laatste patiènten met een prothese-infectie ontwikkelden een aorto-enterale fistel. 28.342

\subsection{PATHOGENESE}

Bij het ontstaan en verloop van een infectie van een abdominale vaatprothese spelen een aantal facroren een rol. Globaal zijn deze onder re verdelen in algemene en meer specifieke factoren. Naast de algemene toestand van de vasculaire pariënt zoals leeftijd en algemene conditie, weerstand tegen infecties en reeds bestaande zickten zijn in dit kader speciaal van belang de eigenschappen van de vaatprothese, de reactie op het contact tussen de prothese en de weefsels en de aard en de virulentie van de micro-organismen die dit contact verstoren. Er bestaan een aantal meer specifieke factoren die de kans op contaminatie en infectie kunnen beïnvloeden. Het implanteren van kunststof vergroot het infectierisico atanzienlijk. Voorhees vond al in 1948 dat een zijden draad in her hart wan een hond na vier weken volle- 
dig was bedekt met endotheelachtig materiaal. ${ }^{305}$ In 1959 werd door Elek en Conen aangetoond dat in aanwezigheid van een zijden hechtdraad het aantal staphylococcen, nodig om een huidabces te veroorzaken, significant kleiner was dan zonder dir corpus aliènum erbij. ${ }^{93}$ Sederdien is veel onderzoek in vrijwel alle heelkundige disciplines gericht op de relatie tussen biomaterialen en de gastheer en de rol van micro-organismen daarbij. ${ }^{161,164}$

\subsubsection{DE PROTHESE}

Ten aanzien van de adherentie van de micro-organismen bestaan er verschillen tussen verschillende soorten prothesen. Weber stelde in 1976 op grond van dierexperimented onderzoek vast dat de infectiekans, afhankelijk van het tijdstip van contaminatie, bij geweven prothesen grorer was dan bij gebreide of velours prothesen. ${ }^{354}$ Nier poreuze polycetrafluorerhyleenprothesen (PTFE) zouden minder gevoelig voor infectie zijn dan poreuze prothesen van dacron. ${ }^{142,218}$ Sugarman (1982) vond dat de adherentie van enterobacteriën aan Dacron in vitro een factor 10 tot 100 groter was dan aan PTFE, terwijl stafylococcen een $10 \%$ tot $30 \%$ betere adherentie aan het hydrofobe PTFE vertoonden. ${ }^{320}$

Onder invloed van de vorming van een biofilm (vide infra) en bepaalde stoffen daarin kan in het dierexperiment de adherentie aan de prothese van onder andere Staphylococcus epidermidis en andere coagulase negarieve stafylococcen, maar ook van Staphylococcus aureus en Psendomonas aeruginosa, nog meer gefaciliteerd worden. 10.16 .17 .142

Schmitt en Bandyk toonden aan dat Staphylococcus epidermidis, Escherichia coli en Staphylococcus aureus zich meer hechten aan dacron dan aan PTFE en beter aan velours dacronprothesen dan aan geweven dacronprothesen ${ }^{285}$ Op grond van verschillende dierexperimentele studies kan het veronderstelde verschil in infectieresistentie russen Dacron en PTFE echter in twijfel worden getrokken. ${ }^{46}$ Bovendien kunnen dierexperimentele onderzoekstesultaten niet zonder meer op de mens van toepassing verklaard worden, te meer omdat er ook tussen proefdieten nog verschillen blijken te bestaan. $2 \% 3.271$

\subsubsection{INTERACTIE TUSSEN GASTHEER EN PROTHESE}

De interactie tussen arteriële vaatprothesen en het levende organisme is her best bestudeerd bij de verschillende vormen van gebreide of geweven en (dubbel-) velours Dacron en polytetrafluorethyleen (PTFE) prothesen in dierexperimenten. Bij de interpretatie van de resultaren is voorzichrigheid geboden ondat er, grote verschillen kunnen bestaan tussen de verschillende gebruikte micro-organismen en diersoorten. 270,271 Waar humane gegevens bekend zijn worden daarom hier dierexperimentele studies buiren beschouwing gelaten. 
De interactie tussen een arteriële vaatprothese en de (menselijke) recipient is een dynamisch gebeuren. De specifieke chemische en oppervlakte eigenschappen van de grondstof van een prothese spelen een rol in de interactie tussen de geimplan* teerde prothese en het menselijk lichaam. Bloedcellen, plasma en weefselvocht en electrolyten veranderen het oppervlak van een implantaat onmiddellijk na imm plantatie. Dit proces wordt conditionering genoemd. Door deze conditionering ontstaat er een biofilm op het oppervlak van her implanraar, bestaande uir elekrolythoudend weefselvochr, fibrinogeen, fibrine, collageen, en proteinen als fibronectine albumine en laminine. 17,1301423,347 Deze instabiele biofilm kan worden beïnvloed door het plasma en daarin aanwezige componenten als weefselenzymen. Bij vaatprothesen ontstaat vrijwel onmiddellijk na het begin van de bloeddoorstroming, op her hele binnenoppervlak een fibrineafzetting en thrombocytenaggregatie, zodanig dat elke dacronvezel compleet daarmee wordt bekleed. ${ }^{246}$ Deze thrombacytenaggregatie is van zodanige omvang dat een daling van het aantal circulerende thrombocyten meerbaar kan zijn. ${ }^{177,299}$ In her fibrinenetwerk worden cellulaire bestanddelen als bloedcellen, fibroblasten en gladde spiercellen opgenomen. Na aanvankelijke aangroei van de fibrinelaag ontstaat er ook afbrak van de fibrinelaag door macrophagen tot een evenwicht tussen aangroei en afbraak wordt bereikt. In die fase van fagocytose ontstaat ingroei van bindweefsel. Her collageen dient als gids voor de celpermeatie en verankert de prothese in het omgevende weefsel. Op termijn blijft er een chronische steriele ontstekingsreaktie bestaan. ${ }^{240}$ De binnenbekleding van de prothese die uit fibrine en bindweefsel bestaat en geheel van hematogene oorsprong is, wordt gewoonlijk de pseudo- of de neointima genoemd, maar lijkt in geen enkel opzicht op de normale intima. Naast de mate van aangroei en afbraak van de fibrine en bindweefsellaag bepaalt ook her karakter van de flow door de prothese de dikte van deze pseudo-intima. ${ }^{311}$ Nadar er een zeker evenwicht tussen beide factoren is bereikt ontstaat er vanuit de arterie bij de anastomosen een zeer partiële bedekking mer endotheel over de fibrinelaag, die zich echter slechrs tor enkele millimeters in de prothese uitstrekt. ${ }^{60,272,281,315}$ In de neo-intima zijn geen lymfespleten of lymfevaten te vinden en er bestaat vrijwel geen interactie tussen de cellulaire elementen binnen de pseudo-intima. ${ }^{311}$ De voeding van deze pseudo-intima geschiedt voornamelijk door directe diffusie vanuit de bloedbaan. Dit betekent ook dat er weinig tot geen immunologische activiteiten binnen de pseudo-intima plaatsvinden.

Aan de buirenzijde van de prothese ontstat direcr na implantarie een dunne vloeistoflaag die de gehele prothese bedekt en die bestaat uir lymfe clie vrij komt uit lymfevaten die beschadigd zijn bij het vrijprepareren van de bloedvaten en het tunnelen van het traject waar de prothese komt te liggen. ${ }^{254,356,357}$ Door dezelfde weefselbeschadiging ontstaat accivatie van fibroblasten en ingroei wan macrophagen waardoor zich in de loop van enkele weken een extraluminale bindweefselmantel vormt die de prothese van de omgeving afschermt en waarin geen wasa va- 
sorum of lymfevaten zijn te vinden. 225,279 Het vocistoflaagie rondom de prothese ligt vijwel opgesloten binnen deze mantel.2292 Door de eigenschappen van de pseudo-intima en de afscherming van de omgeving door de prothesemantel is er vrijwe. geen interactie mogelijk tussen het bloed in het lumen van de prothese en het buitenoppervlak wan de prothese en evenmin tussen het buitenoppervlak van de prothese en de omgevende bindweefselmantel. Dit betekent ook dat de prothese, vooral aan de buitenkant, wrijwel geheel is verstoken van de normale afweermechanismen van het licham en ook slech bereikbaar is woor antibiotica. Het gehele proces lijkt meer op isolatie van de prothese dan op incorporatie van de prothese. ${ }^{356}$

\subsubsection{DEINFECTIE}

Bij het ontstaan wan een infectie rondom de prothese worden de voor iedere infectie bekende fasen doorlopen: eerst contaminatie met de initiele aanhechring van micro-organismen aan her oppervlak van de prothese, daama kolonisatie waana, afhankelijk van de virulentie van de bacteriën en de weerstand van de gastheer, infectie optreedt. ${ }^{347}$

De micro-organismen kunnen zich direct of via de biofilm hechren aan de prothese. Bij deze initiële hechting spelen fysische factoren als onder andere de oppervaktestrukruur, de mate van hydrofobiciteit en de oppervlakrelading van de prothese cen rol. ${ }^{14}$ Her weefseltrauma, het hechtmaterial en een eventucle murale thrombus faciliteren de adhesie van bacteriën. Stabilisatie van de aanhechting van de micro-organismen aan de prothese vindt plaats door produktie van exopolysacchariden door de bacteriën ('slime') en door specifieke verbindingen tussen her bacterie-oppervlak en her geconditioneerde oppervlak wan de prothese.

In het proces van kolonisatie en de groei en verspreiding van de micro-organismen over her oppervlak van de prothese, kunnen afhankelijk van de virulentie wan de bacterièn en de lokale immunnrespons, de micro-organismen uitgroeien of gedurende lange rijd in een extracellulaire slijmlaag ingebed blijen. Het proces van fagocytose in de buurt van de gekoloniseerde prothese in een zure en relatief ischemische omgeving wordt bemoeilijkt doordat zowel door de prothese, als door de daarop aanwezige biomassa (biofilm en "slime") opsoninen en fagocyten worden verbruikt. waardoor fagocytose wrijwel nict platsvindt. De biomassa, die zich niet door leucocyten laat werwijderen, doet de bewreeglijkheid van de leucocyten verminderen en veroorzakt degramulatie van lencocyten waardoor her bactericide vermogen verloren gat. Dezelfde biomassa is er ook verantwoordelijk woor dat de bacteriologische diagnostiek zonder speciale matregelen onbetrouwbaar is, ondat de micro-organismen zeer stevig in deze slijmlatag zijn verankerd. (vide infra) 251 Bij infectie vermenigvuldigen de bacteriën zich in her geisoleerde vochrlaagje tussen de prothese en de omgevende bindweefselmantel. Deze isolatie voorkomt aanvankelijk activatie van het immuunsysteem van de gastheer. Na een periode van 
proliferatie volgr invasie van de prothese en pas als de micro-organismen de bloedbaan bereiken komt de systemische reactie op gang in de vorm van koorts, nyalgie, petechièn en diffuse intravasale stolling.

\subsubsection{MICROORGANISMEN}

Staphyloccus aureus werd in de zevenriger jaren beschouwd als de belangrijkste veroorzaker van prothese-infecries met als tweede belangriike groep (omstreeks 40\%) de gram negatieve bacteriën en daarnaast, in veel mindere mate, Srreptococous, Corynebacteritum en Bacteroides. $37,38193,3.24$ Halverwege de jaren 70 was her aandeel van $S$. aurezus bij prothese-infecties teruggelopen tot 30 à $50 \%$. Lorentzen vond in 1985 in minder dan de helft van de prothese-infecties $S$. aureus. ${ }^{197} \mathrm{Na}$ invoering van (systematische) pre-operatieve toepassing van antibiotische profylaxe, omstreeks 1965, is het relatieve aandeel van S. aureus weer iets toegenomen en met het ontstaan van mericilline-resistente staphylococcen (MRSA) is het mogelijk dat het bellang van $S$. aureus nog meer gaat toenemen. ${ }^{101.357}$ S. aureus bezit een sterk afweermechanisme tegen de defensie van de gastheer én belangrijke eigen aanvalsmiddelen. Onderdelen van de celwand binden onder andere aan het fibronectine in de biofilm rondom her protherisch materiaal. ${ }^{298}$ Oppervlakte eiwitten als bijwoorbeeld proteine-A hebben een sterke affiniteit voor immunnglobuline- $\mathrm{G}$ dat door binding wordt geïnactiveerd. Door produktie van coagulase wordt prothrombine omgezet in thrombine dat de vorming van fibrinevezels faciliteert die het organisme tegen fagocytose beschermen. Daarnaast produceert $S$. aurews een aantal exotoxinen, onder andere het alpha-toxine dat zich aan de menselijke celwand bindt en daarin defecten veroorzaakt leidend tot ionenverlies en uiteindelijk destruccie van de cel. ${ }^{138}$ Tevens geproduceerd delta-toxine verhoogt de permeabiliteit van de polymorfonucleaire leucocyten hetgeen leidt tot dysfunctie en afsterven. ${ }^{166}$ Hyaluronidase breekt her hyalinezuur, een van de belangrijkste componenten van de weefselmatrix, af. Daarnaast bezit de staphylococ de mogelijkheid om lipase, protease en plasminogeenactivator te produceren die worden gebruikt om de afweer van de gastheer uit te schakelen.

Staphylococcus epidermidis, tegenwoordig coagulase negatieve staphylococ (CNS) genoemd, is een micro-organisme dar lange tijd als weinig parhogeen werd beschouwd. Hoewel al in 1958 door Smith werd beschreven dat de coagulase negatieve staphylococcen wel degelijk infecties kunnen veroorzaken, ${ }^{306}$ werd de rol die S. epidermidis speelt bij prothese-infecties pas later onderkend. ${ }^{160,291}$ Bandyk vond S. epidermidis in $60 \%$ als verwekker van de (late) prothese-infectie en Calligaro vond in 1992 bij perifere prothese-infecries drie keer zo vaak S. epidermidis als S. aureus.11,46 Daarnaast is het antal infecties door $S$. epidermidis ook in absolute zin toegenomen. Het gaat daarbij vrijwel altijd om ziekenhuisinfecties, als gevolg van her toegenomen gebruik van invasief onderzoek en implantatie van kunststof ma- 
terialen. $^{34}$ Reeds omstreeks 1980 werd meticilline resistentie van $S$. epidermidis (MRSE) beschreven. ${ }^{165}$ De meeste soorten $S$ epidermidis produceren een uit poIysacchariden bestande extracelluaire mucinekapsel en ondenen hun pathogenicireit, in regenstelling rot de S. aurews en andere niet mucine producerende coagulase negatieve staphylococcen, daardoor voornamelik aan hun wermogen om zich aan prothecisch mareriaal te hechten en weerstand te bieden aan antibiotica en het afweermechanisme van de gastheer. ${ }^{77}, 369$

Bij de gram negatieve micro-organismen speelt Escherichia coli de belangrijkste rol als verwekker van prothese-infecties, mar ook Protews, Pseudomonas en Klebsiella behoren tot de veel voorkomende werwekkers van infectie van vatprothesen.

Over het algemeen is bij intravasculair gebruik van kunststoffen een verschuiving van agressieve pathogenen naar minder agressieve (nosocomiale) micro-organismen te constareren als oorzaak van infecties. ${ }^{135}$

Psendomonats aerughosa produceert evenals S. epidemidis een extracellulair polysaccharide waardoor het micro-organisme in de periprothetische ruimte kan overleven. Invasie wordt mogelijk door de produktie van elastase en collagenase die leiden tot destructie van de vaatwand in de buurt van de anastomose. Produktie van cytoroxin veroorzaakt remming van de fagocytose en lekkage van de celmembraan wan de gastheer leidend tot dysfunktie en afsterven van de cel. Ook produceert Psexdomonas exotoxinen die de produktie wan tumor necrosis factor en interferon onderdrukken. ${ }^{173,202,314}$

De gram positieve enterococcen en streptococcen zijn niet meer zeldzaam bij prothese-infecties. ${ }^{44}$ Daarnaast is de toename van anaëroben (Bacteroides) en gisten (Candida) zorgwekkend., veelal bij menginfecties. ${ }^{13 !}$ Brook vond in 13 van de 19 monsters voor kweek anaeroben (anaërobe gram positieve coccen, Propionibacteriwm en Bacteroides fragilis). 33

Tussen de verschillende soorten pathogene micro-organismen, maar ook binnen een soort, bestaan verschillen in gedrag ten opzichte van biomaterialen en gastheer, hetgeen zich oa uit in de produktie en de samenstelling van de biofilm.

Behalve het verschil tussen $S$. awews en $S$ epidermidis is er maar weing bekend over de verschillen in het ontstaan van de infectie bij de verschillende mico-organismen. Gebleken is dat de bacteriên met hetzelfde gedrag als $S$ epidemidis lange tijd inacrief op de prothese anwezig kunnen zijn, terwijl Psendomonas aemsinosa en 5. aurets meer de arterie zelf aantasten en rot destructie van de anastomose en dus tor bloedingen leiden. ${ }^{106,115}$

Research is gerich op het isoleren van antigenen uit de biofilm om antilichamen te kunnen produceren die adherentie aan en kolonisatie van prothesen kunnen voorkomen. $54,142,251$

In het licht van het bovenscaande is het voor een optimaal resultaat van microbiologisch onderzoek van belang dar zowel materiaalafname daarvoor, als de microbi- 
ologische technieken zijn aangepast aan de specifeke omstandigheden zoals die zich voordoen bij infecties van watprothesen.

Pus of vocht rondom de prothese, de prothese zelf en biopsiën uit de arteriewand, het weefsel rondom de prothese en de abcesmembraan of het valse aneurysma, liefst afgenomen vóór intensieve antibiotische behandeling, zijn de beste specimen voor microbiologisch onderzoek. Een uirstrijkje met een wattenstokje is volstrekt onvoldoende om organismen uit een biofilm op te sporen. ${ }^{131} \mathrm{Als}$ het material nier direct bewerkt kan worden moet her met behulp van transportmedium tegen uitdroging worden beschermd.

Om de micro-organismen uit de fibrine matrix of de biofilm los te maken moeten prothesen of solide monsters gemalen of met ultrageluid worden bewerkt, alvorens ze te incuberen. ${ }^{12,17,352,355}$ Vervolgens zijn zowel aerobe als anaërobe kweek noodzakelijk en dient rekening gehouden te worden met minder frequent voorkomende micro-organismen. ${ }^{250}$

\subsubsection{ANTIBIOTISCHE PROFYLAXE}

Antibiotische profylaxe bij vaarchirurgische ingrepen is niet altijd vanzelfsprekend geweest. In 1972 publiceerde Sziylagyi een serie van 3347 vasculaire ingrepen zonder antibiotische profylaxe met een infectiepercentage van 1.9\%. ${ }^{324}$ Dit infectiepercentage is tenminste vergelijkbaar, zoniet beter, dan dat uit andere series mèt antibiotische profylaxe. Goldstone begon in 1966 met profylactische toediening van antibiotica, maar bleef daarbij een voorstander van lokaal gebruik. Het infectiepercentage daalde (niet significant) van $4.1 \%$ naar $1.5 \% .^{121}$ Jamieson (1975) rapporteerde een daling van de incidentie van prothese-infecties van $7.3 \%$ naar $2.2 \%$ na invoering van intraveneuze antibiotische profylaxe. ${ }^{153}$

Daarna verschenen in de zeventiger jaren studies ${ }^{153,121,196}$ warin duidelijk werd aangetoond dat her infectie percentage kon worden gereduceerd door her gebraik van antibiotische profylaxe, waana dubbelblind studies volgden van oa Kaiser (1978), Salzmann (1982), en Hasselgren (1984). ${ }^{139.162 .276}$ Deze en velle andere publicaties hebben ertoe geleid dat heden ten dage profylaxe algemeen gebruikelijk is geworden. Premoperatief aanvangen met de toediening yan de antibiotische profylaxe werd vanaf omstreeks 1965 geleidelijk ingevoerd en is momenteel algemeen gebruikelijk, terwijl de discussie over de soort en de duur van de profylaxe nog voort gaat. Pre-operatieve roediening wan een cephalosporine (van de derde generatie) is momenteel waarschijulijk de meest gebruikte methode. ${ }^{21}$ Over de duur van de roediening bestaar nog geen eenstemmigheid. 139,145 Her advies van de American Heart Association is evenwel de profylaxe bij hartoperaties in verband met mogelijke resistentieworming niet langer dan 24 uur voort te zetten. ${ }^{72}$ 
Algemeen wordt aangenomen dat contaminatie woornamelijk plaats vindt tijdens de operatie warbij de prothese wordt geumplanteerd en dar de huid de belangrijkste bron is woor prothese-infecties. ${ }^{29,122,324,362}$ Bij het ontstaan van aorto-enterale fistels en crosies treedr, indien men aanneemt dat deze ontstaan door mechanische factoren, contaminatie op nadat de prothese in het darmlumen is gepenetreerd.

Wooster deed in 1985 een prospectieve studic naar intra-operatieve contaminatie, op verschillende tijdstippen en plaatsen tijdens de operatie, bij 77 vatatiènten die geopereerd werden wegens aneurysmata en obstruerend vaadijden, met cephalosporine als profylaxe. $S$ epridernidis bleek het meest voorkomende $(80 \%)$ micro-organisme op de huid (vóón prepareren). ${ }^{362}$ Daarnaast wond hij S. aurews, S. saprophyticu, diphreroiden, anaërobe Streptococcen, micrococcen en meerdere soorten Klebsiella en Protews. De incidentie van prothesecontaminatie was $37 \%$ tot $56 \%$ (en 25-35\% na wisselen wan de handschoenen wór pre-clotting van de prothese)

Andere vel genoemde contaminatiebronnen zijn de aneurysmainhoud, de vaatwand en gangreen en ulcera van de extremiteiten. De lies met de contaminatiemogelijkheden zowel vanaf de huid als vanuir de lymfdieren, met of zonder de anwexigheid van necrose of gangreen aan de betreffende extremiteit, én de risico's op een gestoorde wondgenezing, neemt een aparte positie in. Door meerdere auteurs word aangegeven dat recidiefingrepen, $1,35,267$ spoedoperaties $10,97,153,253,26 \%$ en additionele operaties ${ }^{3.329}$ het contaminatierisico kunnen verhogen (vide infra).

\subsubsection{DE INHOUD VAN HET ANEURYSMA}

Het infectierisico bij een aortaprothese implantatie verschil tussen patiënten met een aneurysma en pariënten die worden geopereerd wegens oblitererend vaatlijden. Naast het feit dat een deel wan de patiënten mer een aneurysma acuut moeten worden geopereerd, hetgeen op zich al het infectierisico kan beinvloeden, kan de normal in een aneurysma aanwezige thrombusmassa een potentiele bron van contaminaric van de geimplanteende prothese zijn.

Ernst was de eerste die in 1977 de andacht vestigde op het belang van de inhoud van het aneurysma als potentiele bron wan contaminatie. Bij 78 patienten vond hii, onder antibiorische profylaxe, in $15.4 \%$ positieve kweken van de inhoud van het aneurysma. Voor geruptureede aneurysma's lag dat percentage veel hoger $(38 \%)$ dan bij de nier geruptureerde aneurysuna's $(10 \%)$. Bij pariënten met positieve kweken uit de aneurysma inhoud vond hij later in $10 \%$ een infectie van de prothese rerwijl dit percentage bij negatieve kweken uir kwam op $2 \% .{ }^{97}$

Evencens in 1977 vonden Williams en Fisher in $10 \%$ van de gevallen posicieve kweken van de inhoud van het aneurysma. Met behandeling door middel van gerichte antibiotica gedurende veerticn dagen postoperatief ontstonden er, ondanks deze contaminatie geen infecties van de prothese. ${ }^{358}$ Scobie beschreef in 1979 in 
een serie van 38 patiënten positieve kweken van de aneurysma inhoud bij 22.6\% en desondanks geen prothese-infecties. ${ }^{290}$ Eriksson (1983) vond bij 85 patienten, warvan er 38 geen profylactische antibiotica kregen, een positieve kweek in $14.1 \%$ van de gevallen, eveneens zonder latere infecties.

Veel van deze gegevens zijn gedateerd en vaak niet erg betrouwbaar, ondat her gehanteerde profylactische antibiorische beleid sterk wisselend was of niet bekend. Ook moet worden bedacht dat préoperatieve antibiotische profylaxe pas wanaf omstreeks 1965 wordr toegepast en dat het nog lang duurde voordat deze werkwijze gemeengoed was.

Op grond van de oudere series kan geen rechtstreeks oorzakelijk verband worden aangetoond tussen de, klinisch nier herkenbare aanwezigheid van bacteriën in de aneurysma inhoud en het ontstaan van een prothese-infectie. Evenmin kan op grond wan deze gegevens een conclusie worden getrokken over het beleid met betrekking tot profylactische behandeling met antibiotica.

In tabel 2.2 is een samenvatting gegeven van de prothese-infectie percentages van woldoende grore recente patientenseries waarbij de antibiotische profylaxe bij prothetische abdominale aortachirurgie pre-operatief werd begonnen en postoperatief werd voortgezet.

Het aantal prothese-infecties dat werd gevonden bij negatieve kweek van de aneurysmainhoud varieerde van 0 tot $2.4 \%$. Bij acuut geopereerde patiënten werden in het algemeen meer positieve kweken gevonden. Posirieve kweken van de aneurysma inhoud komen dus voor in 5 tot $37 \%$ van de gevallen en voornamelijk bij gertuptureerde aneurysma's. Bij de meeste auteurs worden niet méér prothese-infecties na positieve kweken gevonden dan na negatieve kweken, behalve bij Buckels, die bij 7 van de 21 patienten met een positieve kweek een prothese-infectie vond. (nabel 2.2)

Tabel 2.2. Kweek van de aneurysma inhoud en prothese-infecric

\begin{tabular}{|c|c|c|c|c|c|c|c|}
\hline \multirow[t]{2}{*}{ Aureur } & \multirow{2}{*}{$\begin{array}{l}\text { jour } \\
\text { publicarte }\end{array}$} & \multirow{2}{*}{$\begin{array}{l}\text { aantal } \\
\text { pat }\end{array}$} & \multicolumn{2}{|c|}{ poskwcek } & \multirow{2}{*}{ pronts int } & \multirow{2}{*}{$\begin{array}{l}\text { dun } \\
\text { profylaxe }\end{array}$} & \multirow{2}{*}{$\begin{array}{l}\text { soort } \\
\text { antibioncunt }\end{array}$} \\
\hline & & & n & $\%$ & & & \\
\hline Mo Auley & 1984 & 64 & 9 & 14 & 0 & 48 uur & cephalosporine \\
\hline Buckels & 1985 & 275 & 22 & 8 & 7 & $5.7 \mathrm{dg} n$ & wisselend ${ }^{2} ?$ \\
\hline Schwartz & 1987 & 211 & 22 & 10 & 0 & 24 unr & cephalosporine \\
\hline Ilgenfriz & 1988 & 56 & 11 & 20 & 0 & $5 \mathrm{dg} n$ & cephalosporine \\
\hline Brandimarte & 1989 & 90 & 28 & 31 & 0 & 60 utur & cephalosporine \\
\hline Higgins & 1990 & 116 & 6 & 5 & 0 & 48 uur & $?$ \\
\hline Farkass & 1993 & 500 & 185 & 37 & 1 & 24 uur & wisselend $^{b}$ \\
\hline
\end{tabular}

"bij positieve kweek van de inhoud; "de latse 5 jarr van de studie preoperatef begonnen mee meerdere verschillende regimes; " preoperatief begonnen met meerdere wershillende regimes; "inclusief 9 pat met primaine AEF, 16 met aorritis en 25 mee inflammatoire aneurysma's 
Merkwaardigerwijs wordt in publicaties met de resultaten van behandeling van prorhese-infecties niets wermeld over microbiologisch onderzoek van de aneurysma inhoud bij de primaire operatie en geen der in tabel 2.2 genoemde auteurs noemr een positieve kweek van de inhoud als oorzaak voor de infectie.

De literatuur levert dus geen bewijs dat eventuele bacteriën die uit de aneurysma inhoud worden gekweekr, een belangrijke rol spelen in de parhogenese van de prothese-infecrie

Ter voorkoming van uitdroging en electrolytenverlies wordt soms aanbevolen tijdens abdominale vaatchirurgie de dunne darm die buiten de buik word gebracht in een plastic zak te verpakken. ${ }^{275}$ 'Transudaat dat zich in de darmzak ophoopt kan vooral bij langdurige operaties, ondanks profylactische toediening van antibiotica, bacteriën bevatten in 2.5 tot $14 \% .{ }^{35.97 .290}$ Ernst vond zelfs een contaminatiepercentage van $20 \%$ van de inhoud van de darmzak. Er zijn geen studies die een verband tussen de contaminarie van de inhoud van een darmzak en het ontstaan van prothese-infecries aantonen.

\subsubsection{DEARTERIELE VAATWAND}

De vatwand zelf blijkt een potentiële bron wan infectie te kunnen vormen bij de implantatie van een vaatprothese. Wakefield vond bij 84 patiënten tijdens perifere primaire en recidief operaties in 32 gevallen $(38 \%)$ een positieve kweek van zowel de arteriewand, als het periarterieel vetweefsel en bloed. In $71 \%$ betrof het coagulase negarieve staphylococcen. ${ }^{352}$

Macbeth (1984) vond bij 77 patiënten met elecrieve schone vatoperaties, ondanks 72 uur preoperatief begonnen profylaxe met eerste generatie cephalosporine, in $43 \%$ positieve kweken van de arteriewand. In dezelfde studie werden, om contaminatie tijdens de operatie als bron uit te sluiten, bij 20 patiënten controlekweken genomen uit klieren in de hals of de lies of uit retroperitoneaal vetweefsel. In $71 \%$ van de pariënten met positieve kweken van de vaatwand werd Staphyllococcus epidermidis gevonden, terwijl de controlekweken negatief bleven, hetgeen doet vermoeden dar het nier om contaminatie tijdens de operatie gaat, maar om al aanwezige bacteriën uit de vaarwand. De incidentie van prothese-infecties na een gemiddelde follow up van 35 maanden was $8.8 \%$ en infecties kwamen alleen woor in de groep met positieve kweek. De bij de prothese-infecrie gekweekte micro-organismen waren dezelfde als bij de primaire operatie en betroffen in hoofdzaak $S$.
epidemnidis. 200

In de studie van Durham (1987) worden de resultaten beschreven van een dergelijk onderzock bij 172 patiënten: 132 patiënten ondergingen een primaire electieve operatie. De kweek van de arteriewand was positief bij 57 patiênten (43\%). Na een follow up periode van 0 tor 51 maanden trad slechrs één infectie op $(1.8 \%)$. Bij 40 patiënten met secundaire of terriaire operaties, was de incidentie van posi- 
tieve kweken $45 \%$. Een infectie ontwikkelde zich bij $28 \%$ terwijl in de negatieve groep geen infecties ontstonden. Ook hier was $S$. epidermidis het meest gekweekte micro-organisme (58\%). De conclusie was dar de combinatie van réoperatie mer een positieve kweek van de arteriewand een zeer hoog infectierisico opleverde. Een positieve kweek bij een primaire operatie had geen predictieve waarde voor het ontstaan van een infecrie. ${ }^{85}$

Malone (1988) deed microbiologisch onderzoek tijdens behandeling voor de prothese-infectie bij 29 patiënten. Zowel de prothese werd gekweekt als, na debridement, de wand van de aorta. Bij 13 patiënten was de kweek van de aorta positiet. Naaddehiscentie van de aortastomp bleek alléén gerelateerd an een positieve kweek van de aorta en nier aan die van de prorhese en trad alleen op wanneer $S$. attreas of gram negatieve coliformen waren gekweekt (niet na kweek van S. epidermidis) en wanneer niet langdurig antibiotica waren toegediend. ${ }^{203}$

\subsubsection{DE LIESDISSECTIE}

Een gemeenschappelijke factor in de prothetische chirurgie voor zowel aneurysmata als obstructief vaatlijden is de berrokkenheid van de lies in de operatie. In de lies spelen meerdere ongustige factoren een rol en soms tegelijkertijd. Zo worden tijdens liesdissectie lymfevaten en lymfeklieren beschadigd, die bacteriën kunnen bevatten afkomstig uit geïnfecteerde necrose van de voet en hebben voorafgaand aan de operatie vaak catheterisaties via de liesvaten platsgevonden. ${ }^{279}$

S. epidermidis komt voor over her hele lichaam, maar vooral in vochtige gebieden van de huid en slijmvliezen zoals de neusgaten, oksels, liezen en perineum. $S$. atureus komt alleen voor bij dragers, in $\pm 30-35 \%$ van de bevolking, met de grootste concentraties in dezelfde gebieden van het lichaam. Ondanks alle voorzorgen is de kans op contaminatie met deze micro-organismen tijdens de operatie zeer groot. Blomgren cs (1983) vonden tijdens heupoperaties in $43 \%$ contaminatie van de prothese en de wond en Kluge (1974) vonden even hoge contaminatiepercentages van het weefsel gedurende hartoperaties. ${ }^{27,175}$ In het reeds genoemde prospectief onderzoek van Wooster (1985) bij 77 vaatpariënten werd vastgesteld dat contaminatie van de prothese bij $56 \%$ van de patiënten, ontstond tijdens de operatie, onafhankelijk van de samenstelling van het chirurgisch team of het gebruilk van een plastic drape bij het aldekken. Van de handschoenen van de chirurg werden in $53 \%$ dezelfde micro-organismen gekweekt als van de huid van de patiënt: $80 \% \mathrm{~S}$. epidermidis en $20 \% S$. aureus en andere gram positieven. Het contaminatiepercentage van $56 \%$ kon worden verlaagd tot $35 \%$ door voorafgaand aan her manipuleren met de prothese van handschoenen te wisselen. Ondanks deze hoge contaminatiegraad ontwikkelde zich slechts bij $1.3 \%$ van de patiënten een prothese-infectie. ${ }^{362}$ Jamieson (1975) vond slechts. $0.9 \%$ infecties als de lies nier geopend was tegen $3.2 \%$ bij liesdissecties. ${ }^{153}$ 
De adventitia van arterièn en het perivasculaire weefsel is rijk voorzien wan lymfatisch wefsel. De inguinale lym fevaren en klieren draineren de benen en het gebied rond de anus en bevatten niet zelden micro-organismen. Als gevolg van verschillen in de anatomische structuur wan capillairen aan de veneuze kant van de circulatie en Iymfevaten op herzelfde niveau verspreiden bacteriën zich gemakkelijker via de lymfebanen dan via her capillaire nerwerk. 27.4 Bun en Mohr (1984) vonden bij $27 \%$ van overigens gezonde profpersonen bacterièn in de liesklieren. 40 Van de andere kant zijn kweken uit de lies niet altijd positief bij infecties van de voet. ${ }^{86}$ Tijdens de operatie vindt lymfogene contaminatie van prothesen plaats uit gekliefde en gerupturcerde lymfebanen tijdens het wrijleggen van de vaten en het tunnelen wan het prothesetraject. ${ }^{274.356}$

Gatheterisatie van de bloedbaan via de lies kan een extra infectierisico opleveren. Landrenau (1981) wond dat transfemorale angiografie minder dan een week woor de operatie verhoogd infectierisico opleverde, omdat $81 \%$ var de postoperatieve wondcomplicaries was gelokaliseerd aan de kant van de catheterisatie. ${ }^{182}$ Buckels en Wilson (1987) coonden eveneens aan dat transfemorale angiografie de oorzak voor en inguinale infectic kan zijn. 35

Necrose en gangreen van de extremiteiten kan bij obstruerend vaatlijden en mogejijke bron van contaminatie zijn, hoewel over gangreen of necrose aan de extremiteiten als oorzaak voor infectie van een abdominale vatprothese vrijwel geen studies zijn gepubliceerd. In een literatuuronderzoek tot 1974 over 174 tot dan toe behandelde prothese-infecties, waarvan 29 in het aorto-iliacale, en 55 in het aorro-femorale traject, beschrijft Liekweg dat bij 60 gevallen opgave werd gedaan van mogelijk predisponerende factoren. Bij deze 60 patiënten kwam 20 keer een open wond aan de voet voor waarbij uit die wond dezelfde bacterie werd gekweekt als uit de later geinfecteerde prothese. ${ }^{193}$ Een andere studie, die het risico van anastomosen in de lies benadrukt, is die van Lorentzen (1985) waarbij infecties alleén ontstonden als de lies was geopend. ${ }^{197}$ Bij 2411 patiënten, waarvan $20 \%$ een perifete operatie onderging, wond hij tijdens een follow up van wier jaar 62 protheseinfecties. In deze latatste groep bevonden zich 22 patienten (35.5\%) met gangreen of een geinfecteerd ulcus. Helaas werd niet beschreven welke van deze 22 zich in de groep wan de centrale reconstructies bevonden. Bovendien hadden meerdere patienten ook meerdere risicofactoren. Bij patièten met infecties van perifere prothesen worden percentages voor ulcera en gangreen opgegeven tot $47 \%,{ }^{278}$ In andere studies worden necrose en gangreen min of meer terloops genoemd zonder dat duidelijk blijkt of her om perifere of abdominale prothese-infecties gat. ${ }^{29,123,148}$ In een studie van Herbst (1989) over de profylaxe bij abdominale en perifere reconstructies waarbij in $80 \%$ een inguinale incisie werd gemakt bleek het bestaan van ulcera aan de benen het antal prothese- en/ of wondinfecties nier
te beinvloeden. ${ }^{145}$ 
Over oorzaken voor het ontstaan van prothese-infecties enige tijd nà de primaire operatie bestaan, behalve het feit dat vasculaire re-operaties een risicofactor kunnen wormen weinig gegevens. ${ }^{10,178,265,272,285,337}$ Eénderde van alle vaatoperaties zijn ré-operaties. ${ }^{190}$ In de abdominale vaatchirurgie varieert, athankelijk van de duur van de observatieperiode, het aantal re-operaries tussen $6.4 \%$ en 15.6\%. ${ }^{112,133,350}$ In Nederlandse series varieert het percentage re-operaties tussen $10.5 \%$ per 5 jaar voor oblitererend vaatlijden ${ }^{342}$ en $4.4 \%$ tussen 3 en 207 maanden na de primaire operatie voor dilaterend vaarlijden. ${ }^{28}$ In een retrospectief onderzoek van een serie patiènten met een infectie van de abdominale prothese onderging $40 \%$ van de patiënten daaraan voorafgaand een of meerdere vasculaire reoperaties met een gemiddelde van 2.1 operaties per patiënt. ${ }^{236}$ Uit een studie van Durham blijkt dat het infectierisico bij een secundaire of een tertiaire ingreep groter is dan bij primaire operaties In dit onderzoek bleek de combinatie van de risicofactoren re-operatie en positieve kweek van de arteriewand een significant verhoogd infectie risico op te leveren. ${ }^{85}$

\subsubsection{HOSTILE ABDOMEN}

Onder 'hostile abdomen' wordt in de chirurgie een toestand verstaan waarbij de gevolgen van voorgaande buikoperaties, zoals littekens, vergroeingen en enteroanastomosen of de aanwezigheid van stomata, de toegankelijkheid van de buik, de buikorganen of de retroperitoneale ruimte ernstig bemoeilijken en de kans op darmletsels vergroten. ${ }^{338}$ Hierover zijn in de literatuur vrijwel geen gegevens te vinden.

In de buik spelen meerdere risicofactoren een rol. De darm of ureter kan onbedoeld en/of onopgemerkt geledeerd worden. ${ }^{220,250} \mathrm{Al}$ dan niet opgemerkte letsels van de tractus digstivus of de tractus urogenitalis zullen een minstens evengroor contaminatierisico vormen als synchrone ingrepen an dezelfde organen, met dien verstande dat zij op elk moment tijdens de operatie kunnen optreden, ook voordat het achterste peritoneum gesloten is, waardoor de kans op contaminatie groter is dan bij 'gecontroleerde' synchrone ingrepen. (vide infra) Een mogelijke bron van infecrie kan een stoma zijn, zowel een colostoma, als ileostoma of een urostoma. Het bezit wan een stoma wordt wel als contra-indicatie beschouwd voor een abdominale vaatreconstructie met prothese. DeNatale beschreef echter in 1987 dertien patiënten waarvan er twaalf een colostoma of ileostoma hadden of beide en één patiënt met een 'tube' cystostomie, warbij geen infecties van de vaatprothese ontstonden. ${ }^{73}$ 
Retrospecticve vergelijkende cijfers doen vermoeden dat bij spoedoperaties, vooral bij de aneurysmachirurgie, het infectierisico hoger is. $10,37,97,153,267$ Howel het aannemelijk is dat in acute situaries steriliteitsregels minder goed worden nageleefd, is deze stelling niet door prospectief onderzoek onderbouwd. ${ }^{131}$ De bevindingen van Bosman ten aanzien van de wondinfecties doen ook vermoeden dat de infectiekans in de acute pariëntengroep groter is. Bij de beschrijving van de prothese-infecties in zijn materiaal geeft hij helatas niet aan of deze ontstonden na acute of electieve operaties. ${ }^{28}$ Over de betekenis van het deels achterblijvende hematoom na operatie wegens ruptuur van een aneurysma, is geen onderzoek te vinden.

\subsubsection{ADDTTIONELE OPERATIIS}

De meningen over het verrichten van additionele operaries gelijktijdig met het inbrengen van een abdominale vaatprothese zijn controversieel. In dit kader spelen twee vragen een rol: Veroorzaakt de combinatie van beide ingrepen een hogere mortaliteit of morbiditeit, en ontstat er een verhoogde kans op infectie van de prothese?

Het antwoord op deze vragen vereist prospecrieve studies die er niet zijn. In het merendeel van de publicaties wordt achteraf bekeken of synchrone operaties de morraliteir of de morbiditeit nadelig beïnvloedden. Becker (1976) beschreef 14 patiënten met een geïnfecteerde prothese warbij in twee gevallen een tegelijk uitgevoerde cholecystectomie voor de infectie verantwoordelijk kon worden gesteld. ${ }^{13}$

De oudste en meest bekende studie betreffende de toelaarbaarheid van het verrichten van additionele operaties is de publicatie van Ochsner met Cooley en DeBakey uit 1960. ${ }^{234}$ Op voorwarde dat de vaatoperatie zonder problemen was verlopen en het retroperitoneum goed was gesloten werden 804 additionele abdominale operaties synchroon met de prothese-implantatie verricht bij 931 patiënten. Bij $69 \%$ van de patiènten werd een of meerdere additionele operaties uitgevoerd (appendectomie, sympathectomic, cholecystectomie, liesbreukcorrectie, dunne darmresecties en ingrepen aan colon en de maag). Er werd geen verschil in mortaliteit gevonden tussen patiënten met en zonder additionele operaties. Er waren geen mededelingen over prothese-infecties. Over de morbidireit en de duur van de follow up werd niers vermeld. Heczelfde geldt voor de publicatie van Stoll uit 1966 die 8 ingrepen bij 6 patiënten vermeldt, waaronder zelfs een abdomino-perineale resectie en Thompkins uit 1973, die over 22 additionele viscerale procedures berichtre. ${ }^{316,330}$

In 1983 verscheen een arrikel van Thomas over 86 synchrone ingrepen met en zonder openen van de tractus digestivus bij 76 patiënten in een serie van 529 acu- 
te, subacute en electieve ingrepen an de abdominale aorta, waarbij een verhoogde mortaliteit en morbiditeit werd gevonden bij gecombineerde operaties, vooral bij de operaties wegens limb salvage procedures. ${ }^{327}$

Bickerstaf publiceerde in 1984 de resultaten van een serie van 355 aneurysmaresecties waaronder 113 in combinatie met nier vasculaire operaties. Hij vond een verhoogde mortaliteit bij de gecombineerde ingrepen, op grond warvan hij adviseerde zo mogelijk geen additionele operaties te verrichren. ${ }^{23}$

De recente literatuur is meer gericht op de verschillende soorten additionele en synchroon uitgevoerde ingrepen en de risico's per soort additionele operatie.

Cholelithiasis wordt bij patiënten mer een aneurysma in ongeveer 7 procent gevonden. Fry (1986) vond in een serie van 682 patiënten die een abdominale vaatprothese-implantatie zouden moeten ondergaan in $5.1 \%$ wan de gevallen cholelithiasis. Bij de 21 patiënten die eerst in een aparte operarie een cholecystectomie ondergingen was er één waarvan het aneurysma postoperatief ruptureerde en één waarbij thrombosering van her aneurysma optrad. ${ }^{110}$

Ameli (1987) beschrijft 56 patiënten waarbij abdominale vaatprothesen werden geïmplanteerd, zowel wegens dilaterend als oblitererend vaatlijden, waarbij tijdens dezelfde operatie een cholecystectomie werd verricht. Tijdens een follow up van 1-125 maanden (gemiddeld 25 maanden) was er éen patiënt die een prothese-infecrie ontwikkelde (1.8\%), maar die werd niet toegeschreven aan de cholecystectomie. Er waren 5 complicaties van de cholecystectomie. De auteur concludeert dart een concomitante cholecystectomie geen extra risico's oplevert. ${ }^{5}$

Ouriel (1983), String (1984) en Vanek (1988) komen tot de gelijkluidende conclusie dat het verantwoord is om bij toevallig gevonden cholelithiasis zonder cholecystitis, tijdens dezelfde ingreep als de prothese-implantatie, een cholecystectomie te verrichten. $242,319,346$

Thomas publiceerde in 1989 een literatuurstudie uit de engelstalige literatuur over dit onderwerp. Bij 263 patiènten die een gecombineerde aneurysmaresectie en cholecystectomie ondergingen, vond hij slechts cén prothese-infectie. Bij deze pa. tiènt was de cholecystectomie verricht alvorens het retroperitoneum was gesloten. Hij vond in totaal 26 pariënten die eerst de cholecystectomie ondergingen in een voorafgaande operatie. Bij deze patiënten trad na de operatie geen aneurysmaruptuur op. Bij 28 patiënten, waarbij in een separate operatie eerst het aneurysma werd geopereerd, ontstonden driemaal biliaire complicaties bij de cholecystectomie, waaraan één patiënt overleed. ${ }^{327}$ Sonpal (1991) waarschuwr zelfs voor de risico's van post-operatieve billiaire complicaties bij cholecystectomie nà aneurysmachirurgie en benadrukt de veiligheid van de synchrone cholecystecromie bij aanwezigheid van galstenen als het achterste peritoneum maar vóór de cholecystectomie wordt gesloten. 30 \%

Over de vraag of de kans op ruptuur van het aneurysma toeneemt door een voorafgaande laparotomie kan alleen maar worden gespeculeerd. Swanson (1990) be- 
schrijft 10 pariënten waarbij her aneurysma binnen 6 tot 21 dagen na cholecystectomie, pyloroplastiek, dunnedarmresectie of colectomie ruptureerde en vraagt zich af of de laparoromie een inducerende factor zou kunnen zijn ten gevolge varn lysis van collageen. ${ }^{321}$ Een dierexperimentele studie van Cohen en Perry (1984) levert daarvoor onvoldoende aanknopingspunten. ${ }^{321}$

In de Engelstalige literatuur zijn tot 1989 in total 15 maagoperaties en 24 dunnedarmoperaties gelijktijdig met aneurysmaresectie beschreven waarbij geen prothese-infecties optraden. ${ }^{327}$ Over de follow-up wordt echter niets vermeld. Alleen Becker schrijft een prothese-infectie toe aan een gelijkrijdig verrichte gastrosto mie. ${ }^{13}$ Behalwe Ochsner en Bickerstaff beschrijven ook Thomas en Vanek synchrone appendectomièn. 327,346 Thomas adviseert, ondanks her feir dat er geen complicaties zijn beschreven, dat alléén te doen als er tumoren van de appendix worden gevonden.

Coloncarcinomen komen bij patiënten met een aneurysma maar zelden voor. Szilagyi beschreef er in 1967 zes bij 570 patiënten. De frequentie van gelijktijdige diverticulitis of andere colonafwijkingen met een dringende operatie indicatie is nog lager. Her advies van Szilagyi was: Absolute operatie indicaties gaan voor. Bij dreigende ruptuur eerst het aneurysma, bij bloeding, perforatie of obstructie eerst de colonoperatie. Bij afwezigheid van absolute indicaties zou een groot aneurysma ( 6 $\mathrm{cm}$ ) eerst geopereerd moeten worden en bij een klein aneurysma eerst de maligniteit. Bij patiënten met een gemetastaseerde maligniteit moeten symptomatische of grote aneurysma's alleen geopereerd worden als de maligniteit met behulp van effectieve therapie onder controle is. 325

Bij een enquête onder 46 vaatchirurgen vond Lobato (1985) dat eenderde eerst het aneurysma zou opereren, eenderde eerst de toevallig gevonden maligniteit en her andere derde deel zou pas tijdens de operatie een beslissing nemen. ${ }^{194}$ Samenvattend: synchrone ingrepen bij aneurysmachirurgie moeten alleen verricht worden als het niet anders $\mathbb{k}$ kan. Bij reconstructieve chirurgie voor oblitererend vaatlijden dient nog meer terughoudendheid betracht te worden: Her operatierisico is hoger zonder dat daar een bewezen winst tegenover staat. Als het onverhoopt toch noodzakelijk is om twee operaties synchroon te verrichten, dient eerst de vaaroperatie verricht te worden, waarna het achterste peritoneum wordt gesloten, alvorens over re gaan tot de tweede operatie.

\subsubsection{ANDERE PERI-EN PEROPERATIEVE PROBLEMEN}

Diagnostische en technische problemen tijclens de operatie zullen de steriliteit niet bevorderen. Dit aspect van de vaatchirurgie wordt door vele auteurs telkens weer beschreven en het lijkt logisch. Er bestaan echter geen studies die een direct verband leggen russen de technische moeilijkheden, de oplossing daarvan en de gevolgen voor het infectie risico. Hetzelfde geldt voor de duur van de operatie. Bos- 
man vond in zijn onderzoek in de elecrief geopereerde groep een significante stijging van de mortaliteir bij toename van de duur van de operatie. Het aantal infecties in zijn materiaal was te klein om een verband te kumnen leggen ${ }^{28} \mathrm{Er}$ is wel een nadelig verband aangetoond tussen de duur van de operatie en her ontstaan van wondinfecties. ${ }^{68,71,161}$

\subsubsection{NADDANEURYSMA'S}

Over de rol van infectie van de prothese als oorzakelijke factor voor het ontsraan van anastomose-aneurysma's of infectie van een anastomose-aneurysma als oorzaak woor infectie van de prothese is weinig met zekerheid bekend. ${ }^{284}$ Hoewel naadaneurysma's voornamelijk voorkomen in samenhang met een prorhese, 323 worden de lokalisatie en de verschillende soorten arteriële reconstructies, centraal of perifeer, meestal nier onderscheiden. De operatieindicatie van de primaire operatie, obstruerend of dilaterend waatlijden, en de locatie van, en de soort anastomose worden vaak nier vermeld, evenmin alls gegevens over de duur en de volledigheid van de follow-up en de wijze waarop de diagnostiek is verricht. In publicaties over patiëntenseries mer valse aneurysma's worden de geïnfecteerde aneurysma's vaak uitgezonderd. ${ }^{331}$

De frequentie van ontstaan van anastomose-aneurysma*s na aorto-iliacale reconstructies wordt in de literatuur opgegeven tussen $2.8 \%{ }^{98} \mathrm{en} 16.0 \% .^{341}$ Deze frequentie is sterk afhankelijk van de duur van de observatieperiode en de gebruikte detectiemethode, terwijl de helft bij fysisch-diagnosrisch onderzoek niet ontdekt wordt. ${ }^{34}$ i Bij systematisch onderzoek met behulp van echo en DSA kan de frequentie oplopen tot $29.5 \%$ in 4 jaar ${ }^{300}$ Alleen al door deze grote verschillen is de juiste incidentie van naadaneurysma's nier bekend.

Slechts enkele auteurs gaan iets dieper in op een mogelijke samenhang russen prothese- infectie en het anastomose-aneurysma. Kaebnick bestudeerde bij 44 patienten 47 protheserevisies waarvan 26 wegens thrombose van een prothesebeen en 21 wegens anastomose-aneurysma. In total vond hij met zijn kweekmerhode kolonisatie in $79 \%$ van de gevallen, en bij de naadaneurysma's zelfs in $90 \%$. In $69 \%$ werd $S$ epidermidis gekweekt. Na behandeling ontstonden er geen wondinfecties. ${ }^{160}$ Sedwitz vergeleek de pseudoaneurysma's van voor 1977 met een serie in de decade erna. Er bleek een forse toename van het aandeel geïnfecteerde anastomose aneurysma's na 1977 van $8 \%$ naar $30 \%$. Hij concludeert daaruit dat de rol van de infectie bij het ontstaan van anastomose-aneurysma's toeneemt en dat de diagnostiek gericht dient te zijn op het aantonen of uitsluiten van infectie. ${ }^{293}$ Harnoss(1989)beschrijft een serie van 66 naadaneurysma's in tien jaar ontstaan bij 2494 patiënten. Het infectiepercentage bedroeg 17\%, hoger dus dan het infecticpercentage voor abdominale vaatprothesen. ${ }^{137}$ 
Seabrook (1990) onderzocht 45 naadaneurysma's zonder klinische verschijnselen van infectie 10 tor 173 maanden na de primaire operarie. Hij vond bij 27 patiënten (60\%) een positieve kweek, waarvan in 24 gevallen coagulase negatieve staphylococcen. Na resectie van her aneurysma ontstonden er geen infecties. ${ }^{291}$ Downs (1991) onderzochi naadaneurysma"s zonder klinische tekenen van infectie en toonde in 20 van de 26 gevallen electronenmicroscopisch bacteriën aan. ${ }^{80}$ Evans beschrijft 57 patiënten met 72 anastomose aneurysma"s, (bij een incidentie van ongeveer $2.8 \%$ In $7 \%$ ontstond her aneurysma als gevolg van een prothese-infectie en bij recidief valse aneurysma's lag dat percentage bij $29 \% .{ }^{98}$ Het gaat hier echter om zeer kleine aantallen (resp 4 en 2 patiënten). Durham (1987) deed bij de behandeling van infecties onderzoek met behulp van aparte kweken van de arterie en wan de prothese. Hij vond insufficiëntie van de vaatnaad bij $58 \%$ van de pariënten waarbij zowel uit de prorhese als uit de arterie micro-organismen werden gevonden en geen naadinsufficiëntie bij de patiënten waarbij wel micromorganismen uir de prothese en geen bacteriën uit de arterie werden geïsoleerd. ${ }^{85}$

Enerzijds kan infectie dus naadinsufficiëntie en naadaneurysma's veroorzaken en anderzijds kan, afhankelijk van de onderzoekmethode, op de prothese of in de arteriewand van naadaneurysma's contaminatie worden aangetoond zonder dat, ook na operarieve behandeling, een infecrie ontstaat.

\subsection{KLINISCHE PRESENTATIE}

\section{5 .1 TIDDSTIP VAN PRESENTATIE}

De tijd die kan verstrijken russen de implantatie van de prothese en her klinisch manifest worden van de infectie kan sterk variëren en is beschreven van enkele dagen na implantatie van de prothese tor 192 maanden erna. ${ }^{286}$ Op grond van dit sterk variêtend tijdsinterval zijn in de recente literatuur voorstellen gedaan om de prothese-infecties in te delen in vroege en late infecties. $10,41,197,143,253,324$.

De vroege infecries openbaren zich voornamelijk als sepsis, lieswondinfectie of anastomosebloeding en worden in de meerderheid van de gevallen veroorzaakt door virulente bacteriën als $S$. aureus ( $\cot 80 \%$ ) en bepaalde gram negatieve bacterièn als E. coli, Klibsiella, en Enterobatcteriaceae). ${ }^{10}$ Vroege infecrie van een prothese die volledig in de buik gelokaliseerd is, wir zich meestal alleen door onverklaarde sepsis, langdurige ileus, distensie en gevoeligheid van de buik, 253

De late infecries openbaren zich pas na maanden tot jaren als een sinus in de lies, het niet 'ingroeien' van de prothese en aorto-duodenale fistels. Er zijn meestal geen systemische verschijnselen van sepsis, hetgeen samenhangt met het ontstaan van cen perigraft reactie mer vochtproductie, terwijl de prothese ten gevolge van kolonisattie in de biofilm niet op de normale wijze ingroeit. Andere late verschijnselen zijn naadaneurysma's (bij de helfo) of thrombose van (een deel van) de prothese. 
Soms is er alleen maar een infiltraat rondom de prothese dat aanvankelijk vaak op antibiotica reageert. ${ }^{10.126}$ De grens tussen vroege of late manifestatie van de infectie wordt door verschillende auteurs op verschillende tijdsrippen bepaald, maar in de meer recente artikelen ligt dit bij drie à vier matnden. ${ }^{10,131.186}$ In oudere publicaties over prothese-infecties werden voornamelijk vroege infecries beschreven, warbij $S$. aureus een van de belangrijkste werwekkers was, terwijl later duidelijk werd dat bij de late infecties een belangrijke rol is weggelegd roor minder virulente bacteriën als $S$. epidermidis. 10,11

\subsection{SYMPTOMATOLOGIE}

Afhankelijk van oa de samenstelling van de beschreven populatie (PGI of AEF) en de aard van de behandeling (lokaal of radicaal) wordr in de literatuur de klinische presentatie sterk wisselend opgegeven, waardoor cijfers niet vergelijkbaar zijn.

De PGI presenteert zich, afhankelijk van de lokalisatie van de anastomosen als een openliggende wond, abces, fistel, naadaneurysma of een anastomosebloeding in de lies. ${ }^{90}$

Onathankelijk van de lokalisatie van de anastomosen kan een PGI zich manifesteren als een infectie met meer of minder ernstige verschijnselen, variërend van volledig asymptomatisch tot en met een ernstige sepsis en alle acute of chronische vormen van ontsteking daartussen.

Als het om uitsluitend PGI gaat komen afwijkingen in de lies het meest voor, namelijk bij $50 \%$ tot $75 \%$ van de patiënten waarbij de prochese in de lies is geanastomoseerd of waarbij in tweede instantie een anastomose met bijvoorbeeld een perifere bypass werd gemaakt. ${ }^{10,79.265 .339}$ Veel minder frequent kunnen infecties van aorto-bifemorale prothesen zich presenteren in de vorm van een abces of een anastomosebloeding intra- abdominaal zonder afwijkingen in de lies. Sepsis als eerste uiting van een PGI is zeldzaam. ${ }^{261}$ Volledig asympromatische infecties zijn zeldzaam, maar kunnen voorkomen. ${ }^{343}$ Reilly (1984) vermeldt een 'silent graft occlusion' in $17 \%$ der gevallen als enig symptoom van de PGI. 265

Aorto-enterale fistels hoeven zich niet altijd met een bloeding uir de tractus digestivus te presenteren en er kunnen fistels voorkomen zonder tekenen van infectie of bloeding. ${ }^{178.343}$

Het symptoom 'bloeding uit de tractus digestivus bij patiënten met een abdominale vaatprothese in situ' berust bij minder dan één procent van deze patiënten op een aorto-enterale fistel. ${ }^{244}$ In de serie van Reilly (1984) waren 12 van de 33 AEF's occult. Slechts 2 werden in de diagnostische fase vastgesteld, de rest werd bij operatie gevonden. ${ }^{265}$ In series warin alleen aorto-enterale fistels zijn opgenomen varieert het percentage bloedingen van $52 \%$ ror $94 \% 247.343$ Lokale wondproblemen worden bij $25 \%$ gezien. ${ }^{178}$ Bij eenderde van de patiënten kunnen verschijnselen van infectie zonder bloeding worden gevonden (silent fistula) en wordr een fistel 
min of meer onverwach gevonden tijdens operatie ${ }^{266,178}$ Sepsis komt voor in $29 \%$ tor 60\%. ${ }^{19.378 .238}$ Bij bestaan van een AEF is bekend dat een fatale bloeding vaak vooraf wordt gegaan door (een) kleinere bloeding(en) met cen interval van enige uren of dagen. ${ }^{113,178,213,238,340}$ met soms periode(n) van intermitterende buik- of rugkachten met koorts en anemie. ${ }^{248}$ De bloeding bij opname komt vaak mer conservatieve maatregelen tot staan. ${ }^{102.178}$ Soms kan een fatale bloeding het eerste verschinnsel zijn, zoals in de publicatie wan Peck (1992) waar $17 \%$ van alle AEF's zich op deze wijze manifesteerden. ${ }^{247}$ Occulte bloeding bij AEF komt voor bij ongeveet $6 \%$ to $10 \%$, en chronisch bloedverlies bij $18 \%$, terwij bij $21 \%$ tor $27 \%$ de bloeding van een recidiverend type is ${ }^{178,238,265,285}$

Hoe vaak in geval wan AEF een massale bloeding, nopend tot acute operatie, voorkomt wordt uit de literatuur niet duidelijk ondat de indicaties voor acute operaric, indien ze al worden aangegeven, nogal wisselem. In de serie van Kuestner bleek het mogelijk 18 van de 22 patiênten die met een gastro-intestinale bloeding werden opgenomen te stabiliseren, zodar slechts 4 wan deze patiènten (13\%) een spoedoperatie moesten ondergaan. ${ }^{17 \%} \mathrm{Bij}$ anderen variëren de percentages voor acute operatie bij AEF tussen $35 \%$ en $80 \%$.718.20,237 Tot slot kunnen aorto-enterale fistels tor in $30 \%$ van de gevallen voorkomen zonder bloeding 178,265 Hoe groor het probleem is van de patiënt mer vage klachten en een seprisch zicktebeeld ten gevolge wan een prothese-infectie is uit de literaruur niet af te leiden. Perifere septische emboliën als complicatie van prothese-infecties worden beschreven tor $27 \%$ mar meestal veel minder en voornamelijk in samenhang met aortoenterale fistels ${ }^{178,206}$

\subsection{DIAGNOSTIEK}

Optimale behandeling van een prothese-infectie vereist een tijdige diagnose op een moment dat de conditic van de patiënt zo min mogelijk door her ontstekingsproces of door een bloeding gecompromitreend is. 186,267 Een vroege diagnose vereist een hoge mate van klinische argwan. In her geval dat een of meer van de genoemde klinische verschijnselen in de lies aanwezig zijn, lige een werband met de prorhese voor de hand. Als de prothese zich geheel in de buik bevindr of als zich geen gastro-intestinale bloeding voordoet kan het stellen van de diagnose grote problemen opleveren. ${ }^{265,337}$. Alle patiënten met een abdominale vaatprothese die tekenen van een occulte infectie vertonen in de zin van malaise of koorts, of warbij cen hoge of lage gastro-intescinale blocding optreed, zijn verdacht voor een prothese-infectic rot het tegendeel bewezen is. $224,24,265,304,337$

Het definirieve bewijs voor het bestaan van een prothese infectie bestaat uit het antonen wan vocht, $p$ us of bacterièn rondom enig deel van de prothese. Een minimum eis voor het stellen van de diagnose is een losliggende, niet ingegroeide pro-
these. 186,265 
Een bloot liggende prothese in de lies maakt verdere diagnostiek overbodig, althans voor de diagnose. ${ }^{267} \mathrm{Bij}$ AEF is her zien van de prothese in her lumen van de darm of contrastlekkage vanuit de bloedbaan naar de darm bij angiografie bewijzend. ${ }^{178}$ Verder onderzoek $k a n$ in deze siruaties zin hebben om de uitbreiding wan de infecrie na te gaan. ${ }^{224}$ Her doel van aanvullende diagnostiek is het aantonen van een blootliggende prothese in de darm, of het antonen van wocht al dan niet met gasbellen rondom de prothese. ${ }^{125.364}$ Direct zicht op de prothese vanuit de tractus digestivus is mogelijk met behulp van gastroscopie of colonoscopie. Het aantonen van vocht of gas kan op indirecte wijze, via methoden die kunnen worden verdeeld in anatomische en funktionele beeldvorming. (zie 2.6.1 en 2.6.2) Bij deze methoden worden niet zelden afwijkingen gevonden die kunnen bijdragen aan het vermoeden of het bewijs van een infectie, zoals retroperitoneale of buikabcessen, of bijwoorbeeld hydronefrose of osteomyelitis van de wervelkolom. ${ }^{297.365}$ Belhalve chirurgische exploratie, bestaat er geen diagnostische methode die als enige kan dienen om een infecrie of een fistel met zekerheid vast te stellen. ${ }^{261,296,332}$ De diagnose moer derhalve worden bevestigd op grond van een combinatie van gegevens van verschillende methoden.

Bij in gebreke blijven van andere merhoden zal exploratie en kweek van de prothese of het periprothetische weefsel noodzakelijk kunnen zijn. Voor het definitieve bewijs van de infectie blijft exploratie de 'gouden standaard' voor alle niet-invasieve diagnostiek. 218,635

\subsubsection{ANATOMISCHE BEELDVORMING}

Voor anatomische beeldvorming staan echografie, computertomografie (CT), onderzoek met behulp van magnetische resonantie (MRI), angiografie en sinografie ter beschilking:

Echografie is een eenvoudige, goedkope, weinig belastende en nier invasieve onderzoeksmethode, die vrijwel overal beschikbaar is, ook an het bed van de patiënt. ${ }^{122,256}$ De methode is bij uitstek geschikt voor herhaalde evaluatie van oppervlakkig gelegen vaten, voornamelijk in de lies. Door gasophopingen in de buik is het onderzoek van een (retro-peritoneaal gelegen) prothese minder betrouwbaar terwijl de reproduceerbaarheid en de betrouwbaarheid tevens worden beinvloed door de ervaring van de onderzoeker. ${ }^{125,122}$ Uitbreiding van echografie met Doppleronderzoek (duplex-scanning) verhoogt de waarde van het onderzoek doordat de doorgankelijkheid van de prothese kan worden geèvalueerd en vloeistofcollecties en aneurysma's beter van elkaar onderscheiden kunnen worden. Met behulp. van echografie is gerichte naaldaspiratie van vochtcollecties mogelijk, waardoor gedifferentieerd kan worden tussen bijvoorbeeld hematoom of seroom en pus. ${ }^{361}$ De sensitiviteit van echografie is voor het aantonen van vochtcollecties geringer dan die van CT of MRI afbeelding. 
Computertomografie is momented, bij verdenking op prothese-infectie, het onderzock van de eerste keuze omdat het mogelijk is ermee zowel gas als vloeistof rond de prothese ann te tonen. ${ }^{3.132,136}$ CT kan de wat subtielere afwijkingen bij prothese-infecties zoals verdikking van de darmwand bij AEF, en de welke delen rondom de prothese zichtbaar maken. ${ }^{199}$ Low cs wonden bij een onderzoek van 23 AEF's, 12 PGI's en 20 patiënten met een normale, niet geinfecteerde prothese, na vergeliking met de operatieve bevindingen, een sensitiviteit van $94 \%$ en een specificiteit van $85 \%$ voot CT anderzoek. Johnson (1990) en Mark (1985) kwamen tor gelijkluidende bevindingen. 157,205

Direct postoperatief is de aanwezigheid van hematoom en gas rondom de prothese normaal. Het gas dient te zijn verdwenen na twee tot vier weken en het hematoom tnoet na twee tot drie maanden geresorbeerd zijn. ${ }^{235,263}$ Het geleidelijk verdwijnen van vloeiscof of gas rond de prothese bij herhaald onderzoek in de vrocge postoperaticve fase makx een infectie onwaarschijnlijk. ${ }^{107}$ Daarnaast maakt CT onderzoek een gerichte naaldaspiratie mogelijk. Behalve informatie over de prothese kan CT andere oorzaken voor het bestaan van een septisch beeld, zoals andere intra-abdominale en retroperitoneale abcessen en pancreatitis opsporen. In klinische srudies blijkt CT in 63-94\% der prothese-infecries tot een juiste diagnose te leiden. $136,178,272,365$

Aspiratie van vocht rondom de prothese of een kweek van de prothese zonder speciale maatregelen leveren bij microbiologisch onderzoek vaak geen bacteriegroei op, ondat de bacterièn in de bioftm zijn ingekapseld. ${ }^{10}$ Echo-en CT geleide punkrie kunnen derhalve alleen zekerheid over infectie van een prothese verschaffen als her bij punktie verkregen materiaal bacteriegroei oplevert. Dit is sleches in ongeveer $13 \%$ van alle prothesen die na excisie geinfecteerd blijken het geval. ${ }^{181,267}$ Onderzoek met behulp van magnetische resonancie (MRI) is pas mogelijk sedert 1984 Derhalve is er minder ervaring met MRI bij prothese-infecties dan met de computertomografie. De criteria voor het aantonen of uitsluiten van een infecrie zijn bij beide onderzoeken vrijwel de zelfde. MRI kan beter onderscheid maken tussen vloeistof en omgevende weefsels en geeft informatie over de ontstekingsreacrie in de omgevende weersels.

Een belangrijk voondeel wan de MRI zou kunnen zijn dat reconstructie van het beeld in meerdere vlakken mogelijk is waardoor de uirbreiding wan de infectie beter te bepalen zou zijn. ${ }^{59}$ Een ander voordeel is dat er niet persé contrast toegediend hoeft te worclen om te zien of bloed in een prothese stroom of gestold is. Nadeel is dat geen onderscheid tussen gas en kalk in de vatwand mogelijk is. Datrnast is naaldaspiatic in combinatie met MRI vrijwel niet mogelijk, duurt het onderzoek lang en is het (voorlopig nog) duur. In een prospectief onderzoek van Olofson werden ten aanzien van het aantonen van een prothese infectie met MRI betere resultaten bereikt dan met computertomografie. ${ }^{240}$ In de publicatie 
van Aufferman (1989) wordr voor MRI dezelfde specitiviteit gevonden, maar een hogere sensitiviteit als bij her CT onderzoek van Low ${ }^{6.199}$

Sinografie is door meerdere auteurs beschreven, maar er bestaat geen systematische evaluatie van de waarde van dit onderzoek voor de diagnostiek van protheseinfecries. ${ }^{42,108,118,267,366}$ Onderzoek door middel van sinografte is beperkt tot de categorie patiënten die een drainerende sinus in de lies hebben en kan berekenis hebben om te zien of er een verbinding bestaat met de prothese of met andere organen zoals darm of ureter. Overloop van contrast naar de contralaterale zijde van een bifurcatieprothese of omspoelen van het centrale deel van de prothese bewijst dat deze gebieden in elk geval in het proces betrokken zijn. Als alleen een deel van de

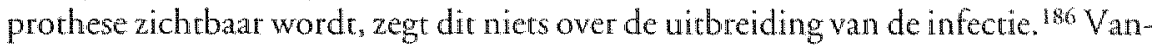
wege het infecrie- en bloedingsgevaar en de geringe ervaring ermee wordr dit onderzoek door sommigen afgeraden. ${ }^{186}$ Seeger vond sinografie in driekwart van de gevallen niet bewijzend voor infectie. ${ }^{294}$

Angiografie kan van nut zijn bij het opsporen van een vals aneurysma of afsluiting van de prothese. ${ }^{178}$ Een aorto-enterale fistel wordr bij angiografie een enkele keer zichtbaar. ${ }^{272}$ Omdat een vals aneurysma behandeling behoeft kan, bij afwezigheid van tekenen van infectie van de prothese, behandeling van het aneurysma een methode zijn om de infectie op het spoor te komen. ${ }^{22,102,366}$ Anderszins verschaft angiografie vrijwel alleen informatic over de intra-luminale anatomie en is vooral van belang voor de strategie bij de behandeling van de infectie. ${ }^{22,118,267}$

\subsubsection{FUNKTIONELE BEELDVORMING}

Voor funktionele beeldvorming komen verschillende varianten wan scintigrafie in aanmerking. Hierbij kan mer behulp van isotopen, gebonden aan lichaamseigen, minder of meer specifieke, met ontstekingsprocessen samenhangende mediatoren een ontstekingsproces zichtbaar worden gemaakt. Scintigrafie kan geen onderscheid maken tussen infectie en ontsteking. ${ }^{2}$

Gallium ${ }^{67}$ bindt rechtstreeks aan plasmatransferrine en wordt uitgescheiden door de nieren en her colon. Het kan gebruikt worden voor het aantonen van infecties. ${ }^{301.302 .186}$ maar het isotoop doet bij scintigrafie ook de lever en milt aankleuren, terwij]. ook het beenmerg, de nasopharynx en lacterende mammae zichtbaar worden. Zowel Fulenwider als Perdue bereikten hiermee goede en reproduceerbare resultaten bij het aantonen van prothese-infecties. ${ }^{112.248}$

De Indium ${ }^{111}$ gelabelde leucocyten scintigrafie is de meest gebruikte nucleaire onderzoeksmethode voor het aantonen van prothese-infecties. ${ }^{136}$ Indium ${ }^{11}$ bindt in principe aan alle cellen en aan plasmatransferrine. In de leucocyten wordt her intracellulair opgenomen en gebonden. Door binding aan leucocyten wordt bij scanning voornamelijk de infectie zichtbaat en minder de ontsteking. De in de literatuur opgegeven sensitiviteit bij de diagnostiek van het prothese-infecties ligr 
tussen 80 en $100 \%$ en de specificitert tussen 50 en $85 \%, 34,187,232,268,293,360$ In Klinische srudies was dit onderzoek in $7990 \%$ positief. 136.367

Bij Indium " gelabelde immunaglobuline scintigrafie kan door binding van Indium 11 aan immunglobuline de toe te dienen dosering Indium fors worden verhoogd. Als gevolg van een lagere opname van het isotoop in de milt kunnen, ten gevolge van een verbererde signaal/ruis werhouding, duidelijker opnamen worden verkregen. Binding wan het Indium aan thrombocyten, die her beeld bij Indium ${ }^{11}$ ? leucocyten scintigrafie kunnen verstoren, vindt bij gebruik van Indium ${ }^{\text {In }}$ gelabeld immunglobuline niet plaats. Er is echter nog maat relatief weinig ervaring met deze methode. In een studie wan 1 a Muraglia (1989) wan 25 patienten werd een diagnostische sensitiviteit van $90 \%$ en een specificiteit van $100 \%$ gevonden bij prothese-infectics. 181

Technetium ${ }^{90}$ hexametazine gelabelde leucocyten scintigrafie is ook een nog relatief nieuwe onderzoeksmethode, warmee blikens een studie van Fiorani uit 1993 goede resultaten kunnen worden geboekx ${ }^{44}$ Bij 37 van infectie verdachte patiënten werd gemiddeld 22 maanden na de primaire operatie zowel computertomografisch als nucleair onderzoek verricht. Met operatie en kweek als gouden standaand werd vootal bij de pariënten mer valse aneurysma's en bij patiënten met volledig aspecifieke verschijnselen met de technetium gelabelde lencocyten scintigrafie berrouwbaarder resultaten verkregen dan met computertomografie en even betrouwbaar als ner indium ${ }^{\text {II }}$ gelabelde leucocyrenscintigrafie.

\subsubsection{ENDOSCOPIE}

Bij patiënten mer cen abdominale vatprothese die zich met een gastro-intestinale bloeding presenteren hangt deze bloeding in minder dan $0.5 \%$ samen met een aorto-enterale fistel ${ }^{2}$ Oesophago-gastro-duodenoscopie is het onderzoek van de eerste keuze bij patiënten die zich presenteren met een gastro-intestinale bloeding en en abdominale vatprothese in situ. Een aorto-enterale fistel kan maar zelden worden gezien en altén als de scopie zich uitstrekt tor in het vierde deel van het duodenum. Nier zelden heeft de bloeding, zelfs bij patienten met een fistel, een andere oorzaak ${ }^{17 \%, 268}$ Met het aantonen vaneen andere bloedingsoorzak is een fistel zeker nog niet uitgesloten. ${ }^{51,168,174,247,267}$ In cen serie van Reilly presenteenden slechts 24 van de 39 pariënten mer een chirurgisch aangetoonde fistel zich met een bloeding uit de bovenste racus digesrivus. Bij de 17 patiënten die stabiel genoeg waren om een gastroscopie te ondergaan werden 22 gastroscopiën verricht waarbij 4 aorto-enterale fistels werden aangetoond $(23.6 \%)$ en 3 bloedingen met een andere oorzaak. ${ }^{267}$ Bij Kuesmer was gastroscopie maar in $11.8 \%$ diagnostisch voor AEF, terwijl bij 53\% andere afwijkingen werden gevonden. 178 Over een eventuele bijdrage van coloscopie an de diagnostiek van een aorto-enterale fistels staat, behalve casuistische mededelingen, geen literatuur ter beschikking. 
Ondanks alle diagnostische mogelijkheden is een zekere diagnose of de mate van uitbreiding van de infecrie rondom de prothese nier altijd voldoende betrouwbar vast te stellen. De diagnose moet in die gevallen worden bevestigd op grond van een combinatie van gegevens van verschillende methoden. Behalve chirurgische exploratie, bestaat er geen diagnosrische methode die als enige in staat is een infectie of een fistel met zekerheid vast te stellen. ${ }^{261,296,332}$. Omdat slechts $0,5 \%$ van de gastro-intestinale bloedingen bij pariënten met een abdominale vaatprothese op een fistel berust is het in het algemeen nier gerechivaardigd een chirurgische exploratie te verrichten voor het aantonen van een aorto-intestinale fistel. ${ }^{2.44}$

Als ondanks uitgebreid onderzoek twijfel blijft bestaan kan chirurgische exploratie nodig en gerechrvaardigd zijn om te zien of de prothese is ingegroeid en of er vocht

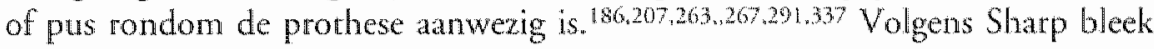
deze werkwijze noodzakelijk bij $15 \%$ van de patiënten waarbij de prothese uiteindelijk verwijderd moest worden. ${ }^{296}$ Kuestner kon bij $33 \%$ van de AEF's preoperatief een zekere diagnose stellen, bij 51.5\% bestond alleen een vermoeden dar bij operatie werd bevestigd en bij 15\% werd de fistel onverwacht tijdens operatie gewonden. ${ }^{178}$ Bergeron (1991) stelde de diagnose in $50 \%$ peroperarief en Secger (1983) bij 60\%. ${ }^{18.294}$ Een en ander hangt uiteraard samen met de ernst van de bloeding en de circulatoire instabiliteit. ${ }^{178,248,337}$

Volgens Lawrence en Reilly is her gerechrvaardigd om, in her geval dat de diagnose reeds is gesteld, via exploratie erachter te komen of een bepaald deel van de prothese vrij van infectie is. ${ }^{186,265}$ Volgens Reilly is exploratie zelfs de enige manier om met zekerheid wast te stellen of een infectie tor een deel van de prothese beperkt is. ${ }^{265}$ In die situatie is her van essentieel belang dat er kweken worden genomen van her aanwezige vocht en zo mogelijk van de prothese en dat het verkregen materiaal op de juiste wijze microbiologisch wordt onderzocht. ${ }^{11}$

\subsection{BEHANDELING}

\subsubsection{BEHANDELINGSPRINCIPES}

Het onbehandeld laten van een abdominale prothese-infectie leidr vrijwel zonder uitzondering tot de dood, meestal door verbloeding. ${ }^{57,152,236,247,337,343}$ Het belangrijkste dilemma dat zich bij de behandeling wan de prothese-infectie voordoet is de wratag of de infectie kan genezen mer (een deel wan) de prothese in sicu, of dat verwiidering van her corpus aliënum absolute voorwaarde claarvoor is. De verschillende gedachten over het verwijderen van de prothese leiden tot twee principieel werschillende mogelijkheden voor behandeling. 
- Volledig verwijderen van de prothese wolgens conventionele chirurgische principes.

- Nier of slechrs gedeeltelijk verwijderen var de prothese berustend op de gedachte dat genezing mogelijk is met de prothese in situ of dat een prothese partieel geïnfecteerd kan zijn.

Na verwijdering van de prothese ontstaat meestal de noodzalk tot revascularisatie. Ten aanzien van de revascularisatie bestaan in principe vier mogelijkheden: anatomische of extra-anatomische revascularisatie en revascularisarie mer autoloog of met niet autoloog materiaal. Het al dan niet, of partieel verwijderen van de prothese staat in principe los van de wijze waarop en het materiaal waarmee revascularisatie plaats vindt.

Ten gevolge van prakrische beperkingen kunnen deze principes niet onbeperkt met elkaar gecombineerd worden. Dat heeft erroe geleid dat er in de praktijk vier hoofdvormen van behandeling zijn ontstaan, twee op basis van her al dan niet radicaal verwijderen van de prothese en twee op basis van de wijze waarop de revascularisatie plaats vindt:

1) radicale behandeling met totale protheseverwijdering met extra-anatomische revascularisavie.

2) niet-radicale behandeling zonder protheseverwijdering on tokale chirurgische maatregelen, of partiele prochescverwijdering met partiële revascularisatie.

3) autologe behandeling bestaande uit partiêle of volledige protheseverwijdering en reconstrucrie mer autoloog materiaal.

4) 'in situ' behandeling door middel van partiele of wolledige protheseverwijdering en anatomische reconstrucrie mer gebruik van prothese, of homoloog biomareriaal

$\mathrm{Bij}$ her merendeel van de patiênten die autoloog of die "in situ" worden gereconstrueerd vind radicale verwijdering van de prothese plaats, waardoor deze behandelingen in die gevallen ook tot de radicale behandeling kunnen worden gerekend Aurologe extra-anatomische revascularisatie is ten gevolge van gebrek aan geschikt autoloog materiaal maar zelden wenselijk of mogelijk, ${ }^{265}$ waardoor de autologe behandeling vrijwel uitsluitend in de anatomische positie plaats vindt, met gebruik van de genuïne arteriën of met autologe venen. ${ }^{57,265}$

"In sicu" revascularisatie betekent revascularisatie in de anatomische lokalisatie en word zowel na partiële als na radicale protheseverwijdering toegepast meestal met gebruik van prothese, maar soms ook met gebruik van homologe arteriën 167
of venen. 307

De extra-anaromische revascularisatie, met name de axillofemorale bypass, geschiedt vrijwel altijd met kunststof prothese. Een combinatie daarvan met autologe vaten kan worden toegepast als een gecontamineerde regio niet geheel vermeden kan worden. Een voorbeeld hiervan is de femoro-femorale bypass, subcutaan danwel perineal, die met autoloog materiaal (de vena saphena magna of een gedesoblitereerde arteria femoralis superficalis) wordt geconstrueerd, al clan niet als on- 
derdeel van een axillo-bifemorale bypass. Tabel 2.3 geeft een samenvatring van de publicaries in her literatuuroverzicht (zie appendix 9.3) ingedeeld naar de daarin gepropageerde of meest toegepaste behandeling, de aantallen patiënten per publicatie en het aantal aan de behandeling gewijde publicaties.

Tabel 2.3. Overzicht wam de behandeling in de literatum (2ie 9.3)

\begin{tabular}{lccc}
\hline behandeling & n & $\%$ & arnal publicaties \\
\hline radical & 804 & 49.7 & 40 \\
autoloog & 106 & 6.5 & 8 \\
nier-radical & 283 & 17.5 & 19 \\
in sicu & 220 & 13.6 & 13 \\
onbekend* & 155 & 9.6 & $(3)$ \\
geen" & 51 & 3.1 & $(13)$ \\
& & & \\
toraal & 1619 & 100.0 & 80 \\
\hline
\end{tabular}

* watarchignlijk radical; " meestal dood woor of tijcens operatie

\subsubsection{PATIENTENSELECTIE EN BEHANDELING}

De hoge mortaliteit en morbiditeit van de behandeling van prothese-infecties (zie 2.8 is het gevolg van meerdere factoren Enerzijds gaat het in de regel om oudere patiënten die geopereerd zijn wegens een gegeneraliseerde atherosclerotische aandoening. Anderzijds zijn deze patiënten ten gevolge van het meestal chronisch beloop van de infectie vaak ernstig metabool en immunologisch gecompromitteerd. Tenslotte vergt de behandeling met verwijderen van de prothese en revascularisatie een complexe, langdurige operarie met veel bloedverlies en perioden van ische-mie van de onderste lichaamshelft. Het resultaat van de behandeling is dus de resultante van de conditie van de patiënt, de ernst van de infectie en de grootte van de operarie die voor de behandeling noodzakelijk is. De beide eerste factoren zijn marginaal te beinnloeden door toediening van antibiotica, verbetering van de metabole conditie en optimalisatie van de cardiopulmonale toestand. 26.7 De derde factor, de operatieve behandeling is de enige die wezenlijk te beïnvloeden is. Dit verklaart dat bij de behandeling van abdominale prothese-infecries van her aloude chirurgische adagium betreffende her verwijderen wan een corpus aliënum bij infectie, onder omstandigheden, kan worden afgeweken zonder een kunstfout te begaan. ${ }^{49,353} \mathrm{Bij}$ de radicale behandeling is getracht het risico te verkleinen door omkering van de volgorde van protheseverwijdering en aanleggen van de extra-anatomische bypass en/of te trachten deze ingrepen als aparte operaties te verrichten. De strategie om met een miet-radicalle behandeling te beginnen en bij mislukking daarvan alsnog over te gaan tot radicale behandeling wordt door som- 
migen eveneens gepropageerd. ${ }^{89,279}$ Beide methoden leiden tor een vorm van paditurenselecric.

De literatur over de behandeling van de geinfecteerde abdominale vaatprothese werd ingedeeld op grond van de door de auteur meest verrichte of aanbevolen behandeling. Een overzicht wan de behandeling volgens deze indeling en de aantallen beschreven pariënren wordt gegewen in tabel 2.3 .

Omdat her in alle gevallen om retrospectieve studies gat blijkt de werkelijk verrichte behandeling van de beschreven patiënten vaak meer gevarieerd te zijn. Ook daaruit bligkt dat er een vorm van selectie plats vindt. Tabel 2.4 geeft een overzicht van de aanbewolen behandelingen (kolommen) en de werkelijk verrichte behandelingen (rijen).

De pre- of peroperatief overteden patienten zin vermeld in de kolom 'geen behandeling. Onbekend betekent dar, ondanks de voorkeur van de auteur, nier duidelijk wordt hoe de patienten werkelijk werden behandeld. Uit tabel 2.4 blijkt dat globaal de helf ( 804 ) van de in de lireratuur beschreven pariënten met een geinfecreerde abdominale vaatprothese (cotall 1619) radical werd behandeld en de andere helf onbekend, of volgens een van de andere methoden. Hierbij moet worden aangetekend dat bij de autologe en de 'in situ' behandeling de geinfecteerde prothese vaak wordt verwijderd.

Tabel 2.4. De behandelingen volgens de indeling in rabel 9.3 en de werkelijk verrichte behandelingen wan abdominale prothese-infecties in de literarum vanaf 1980. Tussen hatkjes her aantal geanalyseerde publicaties, voor verdere toelichting zie tekst in 2.7 .1

\begin{tabular}{|c|c|c|c|c|c|c|c|c|}
\hline Feitelijk verricht: & $\begin{array}{l}\text { radi- } \\
\text { caal }\end{array}$ & $\begin{array}{l}\text { anto- } \\
\log g\end{array}$ & $\begin{array}{l}\text { niet } \\
\text { radicalal }\end{array}$ & in situ & geen & $\begin{array}{l}\text { onbe- } \\
\text { kend }\end{array}$ & $\begin{array}{l}\text { to- } \\
\text { taal }\end{array}$ & $\%$ \\
\hline \multicolumn{9}{|c|}{ indeling in appendix 9.3} \\
\hline radicaal $(40)$ & 784 & 26 & 113 & 66 & 46 & 152 & 1187 & 73.3 \\
\hline autoloog $(8)$ & - & 80 & - & - & - & - & 80 & 5.0 \\
\hline nter-radickal (19) & 5 & - & 160 & - & 5 & - & 170 & 10.5 \\
\hline in $\sin (13)$ & 15 & - & 10 & 154 & - & 3 & 182 & 11.2 \\
\hline cotial $\mathrm{n}$ & 804 & 106 & 283 & 220 & 51 & 155 & 1619 & $\cdots-$ \\
\hline rotal $\%(n=16.19)$ & 49.7 & 6.5 & 17.5 & 13.6 & 3.1 & 9.6 & $\cdots$ & 100.0 \\
\hline
\end{tabular}

Nier alle auteurs die voorstander (lijken te) zijn van de radicale behandeling, behandelden ook âlle patiënten door middel van radicale protheseverwijdering. Door 29 van de 40 auteurs, die werden ondergebracht in de groep voorstanders van radicale behandeling, werden ook andere behandelingsmethoden toegepast. Van de 1187 beschreven patiënten in deze publicaties werden er 784 ook werkelijk radicaal bethandeld $(66.0 \%)$. Hieruit blijkt dat, ook indien de radicale therapie wordt nagestreefd, dit bij $34 \%$ kennelijk nier mogelijk of niet wenselijk is. Tevens 
blijkt hieruit dat selectie plats vond, waarvoor de criteria per publicatie kunnen. verschillen. Enkele algemeen voorkomende selecriecriteria werden reeds beschreven onder 2.2.2. Behalve het operatierisico en de overtuiging dat verwijderen van de prothese nier noodzakelijk is worden voor de niet-radicale behandeling meestal geen andere redenen opgegeven. Ze kunnen berusten op de overtuiging dat de prothese maar gedeeltelijk is geïnfecteerd en derhalve ofwel locaal kan worden behandeld, ${ }^{79,265.296}$ ofwel maar gedeeltelijk hoeft te worden verwijderd al dan niet gevolgd door revascularisarie. Voor het andere deel gaat het om aorto-enterale fistels waarbij zowel de darm als de anastomose wordt overhecht ${ }^{18,102}$ of her deel van de prothese (proximaal of distaal), dat deel uit makt van de fistel, wordt vervangen. ${ }^{51,128,236,332} \mathrm{Bij}$ sommigen is dit het belangrijkste argument voor niet-radicale behandeling.. ${ }^{18,19,51,102,238,247,248,340,34,3} \mathrm{Bij}$ anderen worden de redtenen uit de publicatie nier duidelijk.

Autologe behandeling kan per definitie alleen maar plaars vinden bij patiënten die nog voldoende geschikte autologe arteriën of venen bezitten woor de reconstructie van het aorto-iliacale traject. Voor vrijwel alle patiënten waarbij de primaire operatie plaatsvond wegens dilaterend vaatlijden vervalt die mogelijkheid. Alleen Reilly noemt in haar eerste publicatie (1984) 39 patiënten en in haar tweede publicatie (1987) 20 patiënten met autologe reconstructies. 265,267 Slechts enkele auteurs schrijven over de (magere) resultaten van autologe aorto-iliacale reconstructie mer behulp van de vena saphena magna. ${ }^{198.262}$ Vervanging van de prothese door de vena femoralis superficialis, wordt alléén bij geselecteerde patiënten toegepast en ook bij andere complicaties dan infectie. Clagetr (1997) behandelde $64 \%$ van de infecties met autologe vena femoral is superficialis en Franke (1996) noemt infectie met sepsis veroorzaakt door Pseudomonas Aeruginosa als contra-indicatie voor deze ingreep $.57,58,106$

Bij de 'in situ' behandeling speelt selectie eveneens een belangrijke rol. Sommige auteurs includeren uitsluitend patiënten met AEF, 329,273,349,353 anderen uitsluitend patiënten met PGI. ${ }^{11.214}$ Een ander selectiecriterium is de ernst van de infecrie die bepaald kan worden door de aanwezigheid van retro-peritoneale abces sen, ${ }^{349,35,3}$ of het al dan niet bestaan van sepsis of positieve bloed-of prothesekweken, ${ }^{11.52}$ terwijl ook de aard wan de verwekker een rol kan spelen." De techniek wordt bij daarvoor geschikt geachte patiënten aangepast ${ }^{70,32 \%} \mathrm{en} \mathrm{tenslotte} \mathrm{worden}$ in bepaalde situaties door degenen die daarover kunnen beschikken, met antibiorica (Rifampicin) geïmpregneerde prothesen gebruikr. ${ }^{214,335}$ Bij de methode van Kieffer (1993) worden homografts gebruikt waarvan de beschikbaarheid aanvankelijk een probleem vormde, waardoor 7 patiënten eerst met prothese moesten worden gerevasculariseerd die pas na een periode van $7-45$ dagen door een allograft kon worden vervangen.

Bij de behandeling van de aorto-enterale fistel is naast de behandeling van de prothese-infectie een behandeling van de lesie van de darm noodzakelijk. Een pro- 
bleem dat bij de PGI meestal niet voorkomt is de gastro-intestinale bloeding die een dusdanige circulatoire instabiliteir kan veroorzaken (zie 2.5) dat de behandelingsmogelijkheden beperkt worden. Als de patiënt met conservatieve maatregelen niet gestabiliseerd kan worden, kan de volgorde van protheseverwijdering en revascularisatie na operatieve controle van de bloeding, alsnog worden bepaald, ${ }^{18}$ maar de literatuuranalyse wijst uit dat meestal eerst de prothese wordt verwijderd, gevolgd door revascularisatie, extra-anatomisch of in situ. De invloed op de keuze russen radicale en niet-radicale behandeling door de darmlesie en de daaruit voortvloeiende contaminatie hangt samen met de visie op het ontstaan van de AEF, oorzaak of gevolg van de infectie, en de bevindingen daaromtrent tijdens de operatie. ${ }^{38,43}$

De behandeling van de darm zelf bestaat meestal uit overhechten van her defecr, waarna separatie van de prothese volgt met behulp van een omentumplasrick. ${ }^{178.353}$ Ter bescherming van de darmnaad kan met behulp van cen gastrostomiecatheter en/of een jejunostomiecatherer de darminhoud worden afgeleid. ${ }^{112}$ Separatic van de prothese kan ook door het duodenum antecolisch te leggen. ${ }^{96}$ Gedeeltelijk zijn deze maatregelen dezelfde als die voor bescherming van de aortastomp (zie 2.7.7)

\section{7 .3 RADICALE BEHANDELING}

Klassicke chirurgische principes schrijven, in geval van behandeling van een infectie, verwijdering voor van het corpus aliënum ${ }^{353}$ en daarmee is dan ook de grootste ervaring verzameld. In het literatuuroverzicht (9.3) staan de gegewens over diagnostiek en behandeling verzameld uit de literatuur vanaf 1980 . In total gaat het over 2079 patiënten met prothese-infecties, waarvan 1619 patiënten $(77.9 \%)$ met een abdominale vaatprothese volgens onze definitie. (zie tabel 2.4) In 40 publicaties over de radicale behandeling van de geïnfecteerde abdominale vatprorhese worden de behandelingsresultaten beschreven van 1187 patiënten, waarvan er 784 daadwerkelijk radicaal werden behandeld (66\%). Honderdtweeënvijftig pariënten $(12.8 \%)$ staan vermeld in publicaties warvan de auteurs zeggen voorstanders te zijn van radicale behandeling mar waarbij uit de tekst niet blijkt hoeveel pariënten daadwerkelijk radicaal werden behandeld. ${ }^{64,203,265}$ De andere 251 patiënten $(21.1 \%)$ uit de hiteratuur over de radicale behandeling, worden niet, of volgens een andere methode, bchandeld. Verspreid in de literatuur over de andere vormen van behandeling staan nog eens 20 patiënten vermeld die radicaal werden behandeld. In total werden dus 804 van de 1619 patiënten uit de geanalyseerde lireratuur met een gë̈nfecteerde abdominale varatprothese met zekerheid radicaal behan-
deld $(49.7 \%)$ Mer uizondering van een minderheid, waarbij autologe reconstructie mogelijk is of voor "in situ' behandeling wordt gekozen, heeft de radicale behandeling twee 
specifieke aspecten: Na verwijderen van de prothese moet de aorta worden gesloten en de circulatie van de onderste lichaamshelft moet (meescal) worden hersteld met behulp van een extra-anatomische bypass.

\subsubsection{NIET-RADICALE BEHANDELING}

Niet-radicale behandeling omvat alle vormen wan behandeling zonder of mer gedeetrelijke protheseverwijdering. Hiertoe worden niet alleen de lokale chirurgische behandelingen zoals drainage en đébridement, huid/spierplastieken en het aanbrengen wan spoelsysremen gerekend, maar ook lokale behandelingen van aortoenterale fistels waarbij zowel het duodenum als de anastomose wordt overhecht of waarbij slechts een deel van de prothese wordt verwijderd dan wel vervangen.

De niet-radicale behandelingen is gericht op behoud van (zo veel magelijk van) de prothese. De conservatieve of niet-radicale behandeling van protheseinfecties werd in de zestiger jaren gepropageerd door Carter en Whelan. ${ }^{4}$.

In het literatuuroverzichr (9.3) zijn 19 publicaties vermeld over de niet-radicale behandeling met in totaal 170 patiënten. Vijf patiënten werden nier, en 5 patiënten werden in tweede instantie alsnog radicaal behandeld. Er resteren dus $160 \mathrm{pa}-$ tiënten die een niet- radicale behandeling ondergingen. In 23 van de andere publicaties van het literatuuroverzicht worden nog eens 123 niet-radicaal behandelde patiènten vermeld. In totaal omvat de geanalyseerde literatuur dus 283 niet-radicaal behandelde patiënten. (17.5\%)

In alle gevallen gaat het om geselecteerde patiënten. De criteria voor selectie van patiënten die voor lokale behandeling in aanmerking komen zijn ofwel slecht gedefinieerd ${ }^{136}$ ofwel wordt er in het geheel. geen aanduiding over gegeven, ${ }^{272}$ of ze berusten op nulti-interpretabele grootheden zoals de operabiliteit, conditie en leefuijd wan de patiënt. ${ }^{4}$ Duidelijker selectiecriteria zijn oa: de klinische lokalisarie van de uitbreiding van de infectie, ${ }^{184.215,231}$ de ard van het oorzakelijke micro-organisme, ${ }^{46}$ extracavitaire infecries, ${ }^{47}$ het (al dan niet) functioneren van de prothese, ${ }^{180,249}$ de soort prothese, ${ }^{156}$ het bestaan van valse aneurysma's, intacte anastomosen, ${ }^{223,260}$ infecries gelokaliseerd in de lies ${ }^{4,14,47,215,189}$ en het bestaan van sepsis al dan niet met positieve bloedkweken. ${ }^{46,152}$

Er zijn velerlei vormen van niet-radicale behandeling beschreven. Systemische toediening van antibiotica en abcesdrainage en chirurgisch débridement zijn gemeengoed. Overhechten van (anastomose-)bloedingen niet. ${ }^{126.238}$ De daarnaast toegepaste nevenbehandelingen bestaan uit:

- irrigatie via spoelsystemen met povidonjodium of antibiotica, of andere yormen van lokale toediening van antibiotica, zoals gentamycine kettingen of sponsjes.

- biologische bedekking van de prothese met spier-, huid-, en omentumplastieken, al dan niet gecombineerd met lokale toediening van antibiotica 
- partiele prothesewerwijdering van "minimal grafr excision" tor en met werwijderen van een heel prothesebeen, al dan niet met revascularisatie.

Sommigen maken geen onderscheid tussen deze verschillende nevenbehandelingen of passen ze door en/of na elkar toe. ${ }^{88.136 .143}$

Tabel 2.5. Overzicht wam publicaties over riet-radicale behandeling van abdominale prothese-infecries (zic 9.3)

\begin{tabular}{|c|c|c|c|c|c|c|c|c|c|}
\hline auteur & jaar & tot & aant & $a / L$ & exc & irr & $w$ & $\mathrm{~mm}$ & genta \\
\hline Goshn & 1980 & 13 & 13 & $?$ & $?$ & $\mathrm{a}$ & & & \\
\hline Almgren & 1981 & 7 & 3 & a & & a & & & \\
\hline Kwatan & 1981 & 10 & 5 & $\|$ & & $\mathrm{p}$ & $\mathrm{p}$ & $\mathrm{x}$ & \\
\hline Lorentzen & 1984 & 62 & 39 & 1 & $x$ & & & & \\
\hline Lausten & 1988 & 12 & 10 & 1 & $\mathrm{x}$ & & c & $\mathrm{x}$ & \\
\hline Mixter & 1989 & 2 & 11 & 1 & & & & $x$ & \\
\hline Perler & 1990 & 8 & 3 & 1 & & & & $\mathrm{x}$ & \\
\hline Quick & 1990 & 4 & 4 & a & & a & & & \\
\hline Mielsen & 1901 & 17 & 13 & 1 & & & & & $\mathrm{x}$ \\
\hline Evans & 1993 & 19 & 18 & 1 & & & & $x$ & \\
\hline Grandon & $190 / 4$ & 15 & 11 & a & $\mathrm{x}$ & & & & \\
\hline Morris & 1994 & 10 & 10 & a & & at & & & \\
\hline Calligaro & 1995 & 141 & 14 & 1 & & & $\mathrm{P}$ & & \\
\hline totatal & & 339 & 154 & & & & & & \\
\hline
\end{tabular}

tot: $=$ toraal aantal patiënen per publicatie; aant=aancal patiënten met niet-radicaal behandelde abdominale prothesen; a/: I=behandeling van uirsluitend lies(wond)infecties, a=behandeling van ook het abdominale ded; exceparriële excisie; irt = spoelsysteem: a=met antibiotica, $p=$ met povidon jodium; $w=$ wondwerzorging: $c=$ met chloorhexidine, $p=$ met povidon jodium; mfesecundair stuten met 'rotational muscle fap' genta= behandeling met gentamycine kralen in de wond

Exclusief de casuistische mededelingen (6) en publicaries, warin de lokale behandeling nier of onduidelijk is beschreven of de resultaten niet apart te berekenen

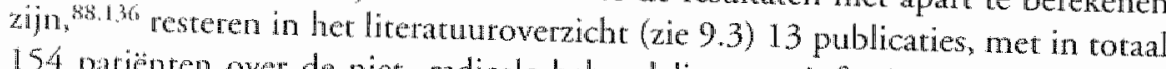
154 patiènten ower de niet-radicale behandeling van infecties van abdominale vataprothesen warvan 9 publicaties 10 of meer patiënten beschrijven, en warin het in $46.9 \%$ ook inderdad om buisprothesen of aortombi-iliacale of aorto-bifemorile prothesen gatat. (zie tabel 2.5)

Het merendeel van de publicaties over de niet-radicale behandeling betreft infecties die zich uitsluitend in de lies manifesteren die local werden behandeld door middel wan spoelen met antibiotica of povidon jodium nast systemische toediening van antibiorica. In 5 publicaries werden de lieswonden al dan nier na lokale 
behandeling gesloten door middel van huid-spier plastieken. Van 4 publicaties over 27 patiënten waarbij de infectie de gehele abdominale prothese had aangetast. beschrijven er 3 de resultaten van het spoelen van het abdominale deel van de prothese met antibiotica. ${ }^{4,223,260}$ De andere publicatie met 10 patiënten, walarbij met lokale chirurgische maatregelen (naast langdurige hoge doses antibiotica) werd getracht de infectie te bestrijden, beschrijft dat dit bij 4 patiënten leidde tot radicale verwijdering van de prothese. ${ }^{126}$

De behandeling van 123 niet-radicaal behandelde patiënten die verspreid in de rest van de literatun vermeld worden, bestond meestal uit particle resecrie van de prothese zonder revascularisatie 272 of met vervanging door een nicuwe prothese of een extra-anatomische bypass. ${ }^{51,236,272,332}$

\section{7 .5 AUTOLOGE BEHANDELING}

Vanwege her hoge percentage infecties en thrombose van de extra-anatomische bypass na radicale protheseverwijdering, de kans op een (vrijwel altijd letale) insuffrciëntie van de aortastomp en de wens lichaamsvreemd materiaal te vermijden, is er steeds een streven naar autologe reconstructie geweest. Ehrenfeld bereikre darmee in 1979 bij de behandeling van de infectie van 15 abdominale vaatprothesen een mortaliteit van $20 \%$ bij $7 \%$ beenamputaties. ${ }^{90}$ De vragen die zich bij autologe reconstructie voordoen betreffen de beschikbaarheid van autoloog vaatmateriaal, de infectieresistentie en de mate van goed functioneren van het autologe materiaal op termijn.

Autologe reconstructic met arteriën is slechts beperkt mogelijk, bijvoorbeeld bij pariënten die zijn geopereerd wegens oblitererend vaatlijden, en waarbij endarteriëctomie verricht kan worden van de eigen aorta of iliacale vaten. Combinaties met gebruilk van de (gedesoblitereerde) arteria femoralis superficialis of de vena saphena magna zijn mogelijk, meestal in de vorm van een unilaterale aortofemorale reconstructie in combinatie met een veneuze femoro-femorale cross over by pass. ${ }^{265,294}$ Naast die uit de kliniek van Ehrenfeld ${ }^{90,265,267}$ zijn er maar enkele publicaties van kleine series betreffende deze autologe reconstructies. ${ }^{89}, 262,265,267.294$ Combinatie van een prothetische axillofemorale bypass met een autologe femorofemorale cross over bypass met behulp van de vena saphena magna of een gedesoblitereerde arteria femoralis superficialis voor het gecontamineerde deel van het operatieterrein is een tweede mogelijkheid die vaker toepasbaar is. ${ }^{7.265} \mathrm{Bij}$ een geinfecteerde buisprothese of een prothese die met de arteria iliaca communis is geanastomoseerd kan de links-rechts verbinding ook (eventueel na endarteriëctomie) worden gemaakt door een directe iliaco-iliacale anastomose. ${ }^{265}$ De perineale route kan een alternatief zijn om een gecontamineerde lies te omzeilen. ${ }^{188}$ Terwijl Moore in 1962 aantoonde dat een veneuze bypass in geïnfecteerd gebied goed kon funcrioneren, zijn er andere auteurs die melden dat autologe veneuze transplanta- 
nen bij ernstige pussende infecties en in het geval dat er geen weke delen bedekking is, kunnen eroderen en rupureren. $33,53,106,183,218$

Gebruk van de vena saphena magna als omleiding in het aorto-iliacale traject blek ten gevolge van het ontstaan wan stenosen als gevolg van intimahyperplasie releurstellend. $57,198,262,294$

Eind jaren tachtig was gebleken dat de vena femoralis superficialis met bevredigende resultaten woor femoro-popliteale owerbrugging gebruikt kon worden, 3,282,288 zonder dat enstige veneuze afvloedbelemmering in her donorbenone stond. 57208,230 Oaaron werd deze vene, die vanwege zijn grotere diameter geschikt. is voor abdominale reconstructies, na verwijderen van de geinfecteerde abdominale prothese gebruike voor reconstructie. ${ }^{103}$ Door Clagett werd deze reconstructie als "Weo-Aorto-Jiac System" betiteld (NAIS-operatie). ${ }^{7}$ Zij bleek bestand tegen zowel de arteriele druk als tegen infectie. De korte termijn resultaten zijn veelbelovend. Of dit op de lange terminn zo bliff, en of deze vene ook zeer enstige infecties kan weerstan zal nog mocten blijken. Daarnaast is het nog de vraag of de zeer grote operatic van de NAIS procedure (6-10 uur durend en met veel bloedverlies) in acute situaties toepasbaar is en bij patiënten in een ernstige septische en/of verbloedingshock gerechwaardigd is. ${ }^{106}$ Clagett rapporteerde alleen over electieve ingrepen. ${ }^{53}$

In tabel 2.6 zijn in rotaal 82 patiënten opgenomen die een autologe reconstructie hebben ondergan, waarvan 59 in verband mer een abdominale prothese-infectie. Claggett en Nevelsteen hebben ieder 2 artikelen gepubliceerd warbij in de tweede publicatie de patiënten uir de eerste nog eens worden vermeld. Derhalve zijn voor de berekening de patiènten uit de eerste publicatie van beiden weggelaten.

Tabel 2.6. Overzich wan de patiènten uit publicaties betreffende radicale protheseverwijdering en autologe reconstructic (zic appendix 9.3)

\begin{tabular}{|c|c|c|c|c|c|c|}
\hline atuteur & jatr & mat & antal & mort & amp & $\mathrm{F}-\mathrm{u}$ \\
\hline Serger & 1983 & 1,2 & 11 & 1 & 1 & \\
\hline Reilly & 1987 & 1 & 20 & 7 & 5 & \\
\hline Quinomes-Baldrich & 1990 & 1 & 3 & - & - & $4.36 \mathrm{mmnd}$ \\
\hline Lonencien & 1986 & 2 & 5 & 1 & 1 & \\
\hline Clager & 1993 & 3 & 20 & 2 & 2 & $22.5 \mathrm{mind}$ \\
\hline Nevelsten & 1995 & 3 & 12 & 3 & 1 & $17 \mathrm{mnd}$ \\
\hline Franke & 1996 & 3 & 7 & 2 & 1. & $23 \mathrm{man}$ \\
\hline
\end{tabular}

atatc= antal behandelde patienten; mat= vor autologe reconstructie gebruikt materiaal

1) wenen en gedesoblirereerde argeriesegmenten; 2) vena saphena magna; 3) vena femoralis superficialis; mort = mortaliteit; amp= amputatiepercentage; $f-u=d u r$ van de follow up 
'In situ' behandeling omvat alle behandelingen mer vervanging van de prothese door nieuwe bloedwaten in het bed van de geïnfecteerde prothese. Voor vervanging kan gebruik gemaakt worden wan prothese of biologisch mareriaal, zowel homologe arteriën ${ }^{167}$ of venen. ${ }^{307}$ De autologe behandeling is in feite ook een vorm van in siru behandeling en indien de geïnfecteerde prothese in zijn geheel wordt verwijderd is in beide gevallen ook sprake van radicale behandeling.

In 1958 werd het eerste (kortdurend) succes behaald door cen aorto-enterale fistel tussen de proximale anastomose van een homograft en het duodenum te behandelen door het duodenum te overhechten en her pseudoaneurysma te vervangen door een nylon prom these. ${ }^{201} \mathrm{Bij}$ de behandeling van primaire infecties van de aorta werden goede resultaten

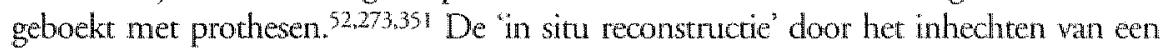
nieuwe prothese in het bed van de geinfecteerde prothese na het sluiten van een eventuele fistel en chirurgisch debridement van het geïnfecteerde gebied, werd in 1961 gepropageerd en in de daarop volgende jaren met een zekere regelmaat uitgevoerd. ${ }^{49}$

Hoewel deze vorm van behandeling en reconstructie strijdig is met de algemeen aanvaarde chirurgische behandeling van een corpus aliënum, kan zij volgens sommigen, bij een juiste patiëntenselectie, toch succes opleveren. ${ }^{12,152,313,353}$ De theoretische voordelen van 'in situ' reconstructie omvatten: kortere operatietijd en korter durende ischemie van de onderste lichaamshelft en bijgevolg minder chirurgische stress, minder amputaties en minder perioperatieve complicaties. ${ }^{273}$ Een belangrijk risico van de 'in situ' reconstructie is recidief infectie met een toegenomen risico op postoperatieve sepsis en naadinsufficiëntie 116,221 Essentieel voor het welslagen is selectie van geschikte patiënren op basis van klinische verschijnselen (de 'perception of degree of infection'). ${ }^{353}$ Goede resultaten zijn te behalen bij de zogenaamde 'low grade' infecties, omschreven als prothese-infecties zonder sepsis, zonder positieve bloedkweken en zonder positieve kweek van de prorhese. ${ }^{152}$

'In situ' behandeling van ernstige infecries met positieve bloedkweken en positieve kweken van de prothese of de vloeistof eromheen of van in de pus liggende prothesen, gaan gepaard met een mortaliteit van $60 \% .{ }^{353}$ Hoewel ook goede resultaten zijn beschreven bij gram negatieve infecries ${ }^{12,46,313}$ zijn de resultaten vooral bij infecties veroorzaakt door $P$. aeruginosa slecht. ${ }^{12,115}$

Selectiecriteria yoor 'in situ' behandeling zijn vaak zodanig dat de wraag rijst of de prothesen die succesvol in siru behandeld werden wel geïnfecteerd waren. ${ }^{1{ }^{19}}$ Van de andere kant kan een infectie met S. epidermidis aan al deze criteria kan voldoen. ${ }^{12}$ Biologische bedekking van de prothese met omentum wordt essentieel geacht, ${ }^{273.353,349}$ terwijl irrigatie met antibiotica en levenslange toediening van antibiotica ook wordt aanbevolen. ${ }^{273}$ Arbitrair is of patiënten die worden behandeld door alleen een deel van de prothese 'in situ' te vervangen ${ }^{12,214,349,353}$ moeten worden gerekend rot de 'in situ' behandeling of tot de lokale behandeling. Hetzelfde geldt voor de methode waarbij via cen 
linkszijdige retroperitoneale benadering een anastomose wordt gemaakt maakt tussen een nicuwe prothese en de infrarenale aorta en vervolgens via tunnels buiten het. geinfecteerde gebied om de prothese naar distaal wordt geleid. ${ }^{70}$

Ten behoeve van de infectiepreventie en de in situ behandeling is een begin gemaakt met het gebruik van met antibiotica geimpregneerde prothesen. ${ }^{63,129,143,227,335}$

Sedert het eind van de jaren tachtig worden ook reconstructies in het bestaande prothesebed verricht met verse ${ }^{174}$ of gepreserveerde ${ }^{167}$ homologe arteriën, en sporadisch met homologe verse cadavervenen. ${ }^{307}$

In het literatuuroverzicht (zie 9.3) komen 13 artikelen voor over 'in situ behandeling' bij 247 patiënten, waarvan $182(73.7 \%)$ met een abdominale prothese-infecrie volgens onze definitie. Honderdvierenviffuig patiënten $(62 \%)$ werden volgens de 'in situ' methoden behandeld, dan wel gerevasculariseerden 28 volgens radicale, lokale of onbekende methode. Verspreid over 15 publicaties over de radicale behandeling in bijlage 9.3 staan nog eens 66 patiënten vermeld die 'in situ' werden gerevasculariseerd.

Patiènten met fistels die worden behandeld door het proximale of het distale segment van de prothese te vervangen, of een zgn 'direct repair' (overhechten van carm en anastomose, al dan niet met omentumplastiek) te verrichten, worden in het literatuuroverzicht tot de lokale behandeling gerekend, maar zouden, afhankelijk van de gekozen definitie, ook bij de "in situ" behandeling ingedeeld hebben kunnen worden. 'Tabel 2.7 bevat een overzicht van 'in situ' behandeling. De daarin beshreven behandelingen en de gebruikte materialen zijn zo heterogeen van aard, dat het trekken van conclusies niet cenvoudig is.

Tabel 2.7. Overzich van patiënten uit publicaries betreffende 'In sïru' behandeling wan geïnfecteerde abdominale vatprothesen (zie appendix 9.3)

\begin{tabular}{|c|c|c|c|c|c|}
\hline auteur & jaar & tor & $\mathrm{pgi}$ & aef & bijz \\
\hline Thomas & 1986 & 8 & - & 8 & inclusief 4 locaal, 2 in sicu, 2 radical \\
\hline Walker & 1986 & 21 & - & 21 & partiele (proximale) vervanging, $2 x$ cen been \\
\hline Snyder & 1987 & 1 & 1 & - & homolong veneus cransplantaat met immuran \\
\hline Vollmar & 1987 & 15 & - & 15 & inclusief 4 primante infecties, deels parricle vervanging \\
\hline Bandyk & 1991 & 14 & 14 & - & segmenten verwangen \\
\hline Jacobs & 1991 & 21 & 12 & 9 & totale vervanging \\
\hline Robinson & 1921 & 4 & - & 4 & exclusief 7 primaire infecties \\
\hline Kieferer & 1993 & 43 & 34 & 9 & allografts 2 recidiewen en in $26 \%$ degeneratie \\
\hline Miller & 1993 & 15 & 15 & - & 6x én been-, 4 proximale en 5 torale vervangingen \\
\hline Knicmeyer & 1994 & 1 & 1 & - & homoloog atterieel \\
\hline Naylor & 1995 & 5 & 4 & I & rifampicin geimpregneerde prothese \\
\hline Speciale & 1997 & 18 & 9 & 9 & inclusief 2 unilaterale infecties \\
\hline Daling m & 1997 & 16 & 12 & 4 & nieuwe runnels, exclusief 12 radicale en 9 niet-radicale \\
\hline rocal & & 182 & 102 & 80 & \\
\hline
\end{tabular}




\subsubsection{SLUITEN VAN DE AORTA}

Na verwijderen van de geinfecteerde prothese zijn er in geval wan een end to side anastomose drie mogelijkheden woor het sluiren van de aorta: primair met inhechten van een, bij voorkeur autologe patch, of afsluiten van de hele aorta. ${ }^{207,265} \mathrm{Bij}$ cen eindstandige anastomose moer de stomp eindstandig worden gesloten, waarbij naadlekkage of ruptuur van de stomp de belangrijkste complicatie vormc. Aanbevolen wordt om de aortastomp met monofilament nier-resorbeerbaar hechtmateriaal in 2 lagen te sluiren ${ }^{136,178,365}$ na verwijdering van alle infectieus weefsel door een uitvoerig chirurgisch débridement van de aorta tot in het gezonde weefsel, inclusief abcesmembraan en prothesekapsel. $7.136,178,200,286,261,296,366$ Zonodig dient het debridement zich uir te breiden tor boven de nierarteriën, waarbij de nieren gerevasculariseerd kunnen worden door middel van een spleno- of hepatorenale bypass. ${ }^{206}$

Om insufficiënrie van de stomp ('blow out') te woorkomen zijn meerdere methoden beschreven zoals bedekken met omentum, ${ }^{30,119,136,151,248,365}$ met prevertebrale fascie ${ }^{10.112 .339}$ of met een seromusculaire jejunumpatch. ${ }^{136.245}$ Andere methoden zijn versterking met fibrinelijm, ${ }^{117}$ aanbrengen van een spoelsysteem met antibiotica, ${ }^{112}$ achterlaten van gentamycinekralen of spons. ${ }^{136.268}$ Over langdurige postoperatieve toediening van antibiotical lopen de meningen uiteen van kort, bij negatieve kweek van de aorta, ${ }^{200}$ tot levenslang. ${ }^{211,252}$

De noodzaak tot revascularisatie van de nierarteriën en het ontstaan van retrograde thrombose van de nierarteriën wordt maar weinig beschreven, maar Reilly vermeldt nadrukkelijk dat op een supra-renale of subdiafragmatische afklemming van de aorta geanticipeerd moet worden. 7,207,267.

Het feit dat ook bij "in situ" reconstructie in 10\% insufficiëntie van de naad optreedt steunt de gedachte dat niet (alleen) het bestaan van de aortastomp maar (ook) de infectie van de vaatwand verantwoordelijk is voor de naadinsufficiëniie. ${ }^{353}$ MacBeth vond insufficientie van de aortastomp in $57 \%$ van de gevallen warin microbiologisch onderzoek van de aortawand bacteriegroei opleverde en geen 'blow our' na negatieve kweken. ${ }^{200}$

\subsection{REVASCUTARISATIE}

Behalve in het geval dat géén revascularisatie wordt verricht, komen er voor revascularisatie de autologe, de in situ reconstructie en de extra-anatomische reconstructies in aanmerking. 


\subsubsection{Geen revascularisatie}

Bij 83 van de 804 radicaal behandelde pariënten (10.3\%) in het literatuuroverzicht (appendix 9.3) werd geen revascularisarie verricht. Vaak gaat het om patiënten die al geamputeerd waren.

In de serie zijn patiënten opgenomen die niet of pas larer, tussen 8 uur en 3 maanden na verwijderen van de prohese werden gerevasculariseerd., waarbij een enkelarm index van 0.3 voldoende zou zijn om reconstructie uit te stellen. ${ }^{339}$ Sommige auteurs zün van mening, dat indien de circulatie na een stabilisatieperiode van 12 tor 24 uur onvoldoende blijkt, revascularisarie nog altijd tot de mogelijkheden behoort. ${ }^{112.339}$ Anderen daarentegen zijn wan mening dat revascularisarie altijd wenselijk is omdat beoordeling van de circulatie van de benen na verwijderen van de prothese nier mogelijk is wegens hyporhermie en vasoconstrictie, ${ }^{90,296}$ en omdat ondanks goede behandeling mer anticoagulantia, irreversibele schade kan ontstaan. Reilly stelt dar de langdurige ischemie rijdens traditionele behandeling ten gevolge van acidose, hypothermie en compartimentssyndromen een zware belasting vormt voor de vitale functies. ${ }^{267}$ Alleen in de oudere literatuur zijn cijfers over niet revasculariseren te vinden: een mortaliteit van $21 \%$ met een amputatiepercentage van $37 \%$ tor een mortaliteit van $60 \%$ met een amputatiepercentage tot $75 \% .121,324$

Patiénten waarbij de primaire operatie werd verricht wegens dilaterend vaatlijden kunnen in het algemeen nier zonder revascularisatie. Patiënten die werden geopereerd wegens obstruerend vaatlijden kunnen dat soms wel, maar ten koste van slechte behandelingsresultaten. ${ }^{12,136}$ De uitkomst van niet revasculariseren is afhankelijk van enerzijds de ernst van de klachten en de collateraalvorming vóór de primaire operatie en anderzijds, en dat geldt ook voor een gethromboseerde prorhese zonder ernstige ischemische klachren, van het intact houden van de collateralen.

\subsubsection{Autologe revascularisatie}

Werd reeds besproken bij autologe behandeling (zie 2.7.5)

\subsubsection{3 'In situ' revascularisatie}

Werd reeds besproken onder 'in situ' behandeling (2.7.6)

\subsubsection{De extra-anatomische revascularisatie}

Met extra-anaromische revascularisatie wordt bedoeld her aanleggen van een nieuwe bloedvoorziening buiten de normale anatomische locatie van arteriën om. Bij 
een geïnfecteerde abdominale vaatprothese, wordt deze vorm wan revascularisatie gekozen om het nieuwe bloedvat buiten de infectiehaard te houden. De axillo-femorale bypass werd in 1962 door Blaisdell en Hall beschreven en in 1963 publiceerden Shaw en Baue over de bypass door het foramen obturatorium. ${ }^{25,297}$ Verder kan gebruik gemaakt worden van een femoro-femorale cross over bypass, subcutaan, door het cavum Retzii of via de perineale route ${ }^{188}$ en allerlei variaties en combinaties van deze technieken. Bij gebruik van deze extra-anatomische reconstrucriemogelijkheden worden, na de femoro-femorale cross over, de beste resultaten bereikt met de axillo-bi-femoralle bypass. ${ }^{144,195} \mathrm{Bij}$ de behandeling van geinfecteerde waatprothesen bestaat een extra probleem als ook de lieswond is geïnfecteerd. In dar geval moer een distale anastomose worden gemaakr mer de arteria profunda femoris of de arteria poplitea en soms kan het geïfecteerde gebied alleen worden omzeild door gebruik te maken van dubbelzijdige axillo-femorale reconstructies naar de arreria profunda femoris of de arteria poplitea. ${ }^{112,136,261,296} \mathrm{De}$ belangrijkste complicaties wan de extra-anatomische bypass zijn infectie en thrombose.

\subsubsection{Timing van de extra-anatomische revascularisatie}

In de discussies over het aanleggen van een extra-anatomische bypass vóór of na protheseverwijdering staat het risico van een infecrie rondom de nieuwe prothese tegenover de schade die wordt aangericht door langdurige ischemie van de onderste lichaamshelft bij pariënten die door de aard wan her onderliggend lijden en de gevolgen van de infectie zowel metabool als immunologisch gecompromitteerd zijn. Omdat deze factoren slechts beperkt voor behandeling toegankelijk zijn, kan het operatierisico alleen gereduceerd worden door de risico's van de ingreep zelf zoveel mogelijk te beperken. $267,357,339$

De zogenaamde 'traditionele' behandeling (verwijderen van de prothese met aansluitend axillofemorale bypass) veroorzaakt een vrij langdurige periode van ischemie voor de onderste lichaamshelft. Om dit te voorkomen kan de volgorde van beide ingrepen worden omgekeerd, hetgeen ook wel de 'sequentielle' methode wordt genoemd. 50,94,337 De gedachte dat de risico's over 2 minder zware ingrepen worden verdeeld als de prothese enkele dagen na het aanleggen van de extra-anatomische bypass wordt verwijderd, de zogenaande 'staged' behandeling met een gunstige invloed op de mortaliteit wordr door meerdere auteurs gesteund. Omkering van de volgorde was mogelijk zonder het infectierisico te verhogen, terwijl deze 'staging' eveneens een gunstige invloed bleek te hebben op het amputatiepercentage. ${ }^{7,236,267}$ 'Staging' is uireraard nier mogelijk bij de circularoir instabiele patiënt met een AEF. Een overzicht van de in de literatuur vermelde wijze van extraanatomische revascularisatie is gegeven in tabel 2.8 . Hieruit blijkr dat de traditionele en de sequentiële methode tot nu toe her meest werden toegepast en dat er een verschuiving lijkt te ontstaan in de richting van de gestadieerde behandeling. 
Tabel 2.8 . Overzich wan de wolgorde van protheseverwijdering en extra-anacomische revascularisatice

\begin{tabular}{|c|c|c|c|c|c|c|c|c|}
\hline atureur: & jar & rotaal & $\operatorname{rrad}$ & seque & stiaged & synch & in situ & geen revascularisanie \\
\hline Turnipseed" & 1983 & 15 & 7 & - & 8 & - & - & 0 \\
\hline Bandyk & 1983 & 15 & 2 & 10 & 2 & 1 & & \\
\hline Reilly.1* & 1984 & 90 & - & & 15 & 70 & & 5 \\
\hline O'Hara & 1986 & 54 & 38 & & 16 & & - & - \\
\hline Reilly.2* & 1987 & 101 & 7 & 38 & 19 & 20 & & 15 \\
\hline Yeager* & 1990 & 38 & 9 & 24 & & 3 & 2 & - \\
\hline Schmitt* & 1990 & 20 & 14 & - & 5 & & & 1 \\
\hline Quinones & 1990 & 45 & 32 & - & 3 & 1 & - & 9 \\
\hline Bacourt & 1992 & 98 & 27 & 58 & 9 & - & - & - \\
\hline Peck* & 1992 & 19 & 11 & - & 8 & - & - & - \\
\hline Bunt & 1993 & 20 & - & - & 20 & - & - & - \\
\hline Lehnert & 1993 & 21 & 6 & - & 1.5 & - & - & - \\
\hline Kuestner ${ }^{*}$ & 1995 & 33 & 1 & 16 & 16 & - & - & - \\
\hline
\end{tabular}

* uitsluitend AEF of meerdere pacienten mer ASF; trad=araditionele behandeling: eerst prothese verwijderen watma ansluirend extra-anatomische revascularisatic; seque=sequentiele behandelingecrs extra-anatomische revascularisatie en ansluitend verwijderen van de prothese; 'staged'=gestadieede behandeling: eerst exrra-anatomische rewascularisatie en enkele dagen larer verwijderen wan de prothese: synch=synchrone behandeling: verwijderen van de prothese en autologe reconstructie in één operarie

\subsection{RESULTATEN}

Doel van de behandeling van de geinfecteerde abdominale vaatprothese is een definitieve behandeling van de infectie rnet behoud van het lewen en beide onderste ledematen. Eetn betrouwbare analyse van de resultaten van de behandeling van de geinfecteerde abdominale vatprothese aan de hand van literatumgegevens is a an beperkingen onderhevig doordar vrijwel geen van de gepubliceerde series rechtstreeks mer elkaar vergelijkbaar zijn ten gevolge van selectie. De samenstelling van de verschillende gepubliceerde series wisselt sterk, niet alleen nat de verhouding russen de aantallen PGI of AEF, maar ook naar de verhouding tussen abdominale en andere dan abdominale prothese-infecties. De selectie en inclusiecriteria van de patièntenpopulaties kunnen sterk wisselen (2.2.2) De verschillen lopen uiteen van:" "al- leen de patiënten die voldoen aan het behandelingsprotocol" 78 tor een overzicht van alle aangeboden of eigen patiënten met een prothese-infectie, ook als zij niet (meer) werden behandeld of rijdens behandeling overleden.

De gehanteerde definitie voor mortalieit kan in de publicaties variëren van de totale mortaliteit tot de uirsluitend aan de infectie gerelateerde mortaliteir, waarbij de definitic van de laatste omsch rijving niet wordt gegeven. De definitie van de be- 
thandeling is ook niet altijd eenduidig. Bij de radicale behandeling wordt soms een manchetje prothese in situ gelaren om de arterie te (kumen') sluiten, anderen doen er alles aan om de prothese volledig te verwijderen. Her verwijderen van een deel van de prothese kan tor de lokale behandeling worden gerekend of tot de 'in situ' behandeling. De wijze van weergeven van de resultaten, bijwoorbeeld door her wel of nier gecombineerd weergeven van de behandelingsresultaten voor PGI en AEF, of her weergeven van verschillende behandelingsmethoden onder én noemer, kan het zicht op het uiteindelijke resultat enstig vertroebelen.

Op grond van deze beperkingen kunnen de hierna volgende cijfers niet meer zijn dan cen globale indicatie van de bereikte resultaten uit de literatuur.

\subsubsection{VROEGE RESULTATEN}

\subsubsection{Operatiemortaliteit}

De operatiemorraliteit is in een deel van de publicaties voor de verschillende behandelingsvormen apart te berekenen, echter zonder onderscheid te kunnen maken tussen PGI en AEF. Slechts in een klein aantal publicaties staan de uitkomsten voor PGI en AEF wel apart vermeld.

De problemen omtrent niet of verschillend gedefinieerde operatiemortaliteit (30-clagen of ziekenhuismortaliteit), verschillende inclusiecriteria voor mortaliteit, (alleen aan de infectie gerelateerde of alle mortaliteit) en de selecrie (al dan niet meetellen van pre-operatief of tijdens de operatie overledenen, of pariënten die wegens slechte conditie niet meer werden geopereerd) konden niet worden opgelost. Hierdoor mogen de weergegeven mortaliteitscijfers niet anders dan globaal geïnterpreteerd mogen worden.

Tabel 2.9 toont de gemiddelde operatiemortaliteit van verschillende behandelingswormen zoals deze zijn weergegeven in publicaties met uitsluitend PGI patiënten (23 publicaries), of uirsluitend AEF pariënten ( 10 publicaties) en de mortalireit van alle publicaties (PGI en AEF tesamen) in het literatuuroverzicht. (appendix 9.3)

Tabel 2.9. Gemiddelde operatiemortaliteit in procenten voor AEF en P'GI per type beloandeling berckend uit de publicaries van her literaturoverzicht wan appendix 9.3

\begin{tabular}{lccc}
\hline behandeling & PG* & AEF $^{*}$ & total $^{*}$ \\
\hline radical & 31.5 & 46.6 & 35.3 \\
nier-radical & 10.8 & - & 10.8 \\
autoloog & 12.0 & 13.0 & 11.6 \\
in situ & 4.4 & 7.2 & 8.0 \\
& & & \\
totalal & 15.4 & 33.0 & 22.1 \\
\hline
\end{tabular}

"De series mer uitsluitend PGI of AEF; "Alle series bevatrende PGI en AEF 
De verschillende publicaties vertonen een dermate belangrijke spreiding dat dit wezenlijk is voor de beoordeling en eventuele vergeligking van de resultaten. In tabel 2.10 is deze spreiding zichrbaar gemaakt voor de verschillende behandelingen van de beide uitingsvormen van de prorhese-infecties.

Tabel 2.10. Spreiding van de operaciemorralireir voor PGI èn AEF in procenten per type behandeling berekend uir de tabel (zie 9.3)

\begin{tabular}{llllc}
\hline behandeling & minimum maximum & gemiddeld mediaan \\
\hline radical & 3.7 & 82.0 & 35.3 & 27.4 \\
niet-radical & 0 & 30.8 & 10.8 & 7.7 \\
auroloog & 0 & 28.6 & 11.6 & 10.9 \\
in situ & 0 & 27.8 & 8.0 & $*$ \\
& & & & \\
toraal & 0 & 77.0 & 22.13 & 17.8 \\
\hline
\end{tabular}

* niet ce berekenen

De mortaliteir wan de behandeling van AEF is significant hoger dan van de PGI.265 In de oudere literatuur (tor 1983) worden percentages voor cle mortaliteit van de behandeling van de AEF opgegeven van $37-75 \% .{ }^{69}$ In de loop van de jaren is er zowel bij de behandeling van de $\mathrm{PGI}$ als de AEF een verberering van de resultaten te constateren. ${ }^{41,236,267,366} \mathrm{Bij}$ de AEF is deze trend minder sterk. De oorzaak kan gelegen zijn in de toestand bij opname of een hoger percentage stompinsufficiëntie. ${ }^{178,266}$ Een literatuuroverzicht, van voornamelijk Amerikaanse literatuur tot 1992, kwam, onafhankelijk wan de aard van de behandeling, voor PGI tot een totale mortaliteit van $21 \%$ en voor AEF tot $46 \% .{ }^{367}$ De laagste gepubliceerde operatiemortaliteit bedroeg $14 \%$ voor PGI en $19 \%$ voor AEF.267

\subsubsection{Peri-operatieve amputaties}

Ten aanzien van amputaties wordt in de meeste publicaties geen onderscheid gemaakc tussen de perioperatieve en de torale aantallen amputaties. In 12 artikelen van het literatuuroverzicht (appendix 9.3) is vermeld hoeveel (major) amputaties in de postoperatieve periode werden verricht. Het percentage varieert tussen $0 \mathrm{en}$ $43 \%$ mer een gemiddelde van $12.7 \%$ en mediane waarde van $10.8 \%$.

\subsubsection{Peri-operatieve aortastompinsufficiëntie}

Gegevens over aorrastompinsufficiëntie 'blow our' bij radicale behandeling worden aangetroffen bij 23 publicaries in het literatuuroverzicht (appendix 9.3), waarvan er 8 mededelingen doen over stompinsufficiëntie in de perioperatieve periode. 
Uit de getallen blijkt een postoperatieve blow our' frequentie van gemiddeld $9.1 \%$ (mediaan $4.4 \%$ ) met een maximum van $30 \% .332$

\section{8 .2 LATE RESULTATEN}

Voor de gegevens over de late mortaliteit en morbiditeit gelden in nog sterkere mate dezelfde beperkingen als de reeds genoemde bij de wroege resultaten.

\subsubsection{Mortaliteit}

Over de resultaten van de behandeling op lange termijn is maar weinig bekend. In 28 van de 80 artikelen (35\%) van het literatuuroverzicht (appendix 9.3) wordt niets over de duur van follow-up vermeld. De gemiddelde duur van de follow up in de 52 andere publicaties bedraagt gemiddeld 29.3 maanden (mediaan 27.9) en ligt voor de verschillende behandelingsvormen tussen 15 en 35 maanden. Ook hier wordt soms alle mortaliteit vermeld en in andere gevallen alleen de mortaliteit die aan de infectie te wijten is, terwijl dit gegeven in de meeste gevallen ontbreekt. In tabel 2.11 wordt de gemiddelde mortaliteit van de werschillende behandelingen en de daarbij behorende duur van de follow up weergegeven. Indien een definitie van de mortaliteit en de duur van de follow up wordt vermeld gaat het on de totale mortaliteit tot het einde van de follow up periode, inclusief alle doodsoorzaken. Indien een nadere definirie van de mortaliteit of de duur van de follow up ontbreekt, wordt slechts de door de auteur opgegeven mortaliteit in de berekening betrokken. Slechts enkele auteurs geven een life table analyse. $7,178,236,267$

Tabel 2.11. Gemiddelde mortaliteit in procenten en de bijbehorende gemiddelde duur van de follow up in maanden per type behandeling in relewante publicaties in her literatuuroverzicht (appendix 8.3)

\begin{tabular}{lll}
\hline behandeling & $\begin{array}{l}\text { gemiddelde } \\
\text { mortaliret }\end{array}$ & $\begin{array}{l}\text { gemiddelde duur wan } \\
\text { de follow up }\end{array}$ \\
\hline radicaal & 48.1 & 33.0 \\
locaal & 32.6 & 35.0 \\
autoloog & 21.6 & 15.4 \\
in siru & 19.7 & 27.5 \\
rotaal & 36.5 & 29.3 \\
\hline
\end{tabular}

Volgens deze berekening met alle daarbij behorende beperkingen zou de gemiddelde overlevingsdur voor de radicale behandeling uitkomen op $51.9 \%$ na 2.75 jaar. Op grond van geselecteerde, uitsluitend Amerikaanse, verzamelgegevens over 
de radicale behandeling zou er een overleving zijn van $60 \%$ na én jaar en $50 \%$ na 5 jaar. ${ }^{367}$

Persisteren wan de infecrie vormt, naast pulmonale insufficiëntie en maligniteiten en progressie van, niet alleen het perifeer oblitererend, maar ook van het renale, het cardiale en her cerebrale vaatijden, een belangrijke bijdrage aan de mortaliteir op lange termijn. Na radicale behandeling kan persisteren van de infectie zich maw nifesteren in de vorm wan insufficièntie van de aortastomp of als infectie van de (nieuwe) prothese, de autologe reconstructie of de extra-anatomische bypass. Na nier-radicale behandeling presenteert een persisterende infectie zich afhankelijk van de verrichte behandeling hetzelfde als de prothese-infectie (zie 2.5) al dan niet in combinatie met infectie van een eventuele extra-anatomische bypass.

\subsubsection{Insufficiëntie van de aortastomp}

Insufficiëntie van de aortastomp is het gevolg van persisteren van de retroperitoneale infectic, warschijnlijk ten gevolge van achterblijende necrose en ander infectieus materiaal van de abceswand, de kapsel rondom de prothese, necrotische darmwand en het geinfecteerde deel van de aorta. Door een uirvoerig débridement van al dit retroperitoneale weefsel en sluiten van de aorta op een niveau waar de wand macroscopisch gafen gezond was kon het antal stompinsufficienties met $19 \%$ terug worden teruggebracht zonder boven het niweat van de nierarteriën te komen. ${ }^{78}$

Stompinsufficiëntie op vroege-én lange termijn blijkt uir de literatuuranalyse (appendix 9.3) voor te komen in gemiddeld $13.7 \%$ (median $12.3 \%$ ) met een maximum van $30 \%$. Bij de in situ behandeling varieert de frequencie van insufficiëntie van de anastomose tussen 12.5 en $16.6 \%$ met een gemiddelde van $14.0 \%$ (mediaan $13.0 \%$ ).

\subsubsection{Amputaties}

In 47 publicaties in het literaturoverzicht (appendix 9.3) wordt een amputariepercentage opgegeven. Voor een ded gat het om de perioperarieve amputaties (zie perioperatieve amputaties) In de rest gat her om het totale amputatiepercentage per publicatie met voor iedere auteur eigen definiries, in-en exclusiecriteria en duur van de follow up. Het amputatiepercentage kan op termijn oplopen tot $43 \%$ mer een gemiddelde warde wan $15.7 \%$ en median $13.3 \%$. 


\subsubsection{Thrombose van de extra-anatomische bypass}

In de reconstructieve vaarchirurgie is met behulp van de axillo-bifenorale bypass een 5-jaars doorgankelijkheid te behalen van omstreeks $70 \%$. Dit resultat wordt alleen overtroffen door de femoro-femorale cross over bypass. Voor de unilarerale en de bilaterale axillofemorale bypass zijn de resultaten anzienlijk slechter. ${ }^{1 \text { in }}$ Bij de behandeling van de abdominale prothese-infecties is her niet allijd wenselijk of mogelijk om een axillo-bi-femorale bypass aan te leggen met als gevolg dat daarbij de te behalen doorgankelijkheidspercentages lager zijn.

Gegevens over de doorgankelijkheid van de extra-anatomische bypass na radicale verwijdering van de prothese worden aangetroffen in 10 van de 40 publicaties hierover in het literaturoverzicht. (appendix 9.3) De frequentie van afsluitingen van de extra-anatomische bypass varieert hierin tussen 9.5 en $53 \%$ en is gemiddeld $23.9 \%$ (mediaan 21.6).

\subsubsection{Infectie van de extra-anatomische bypass}

Prothese-infecties van de axillofemorale bypass ontstaan in de reconscructieve chirurgie tot in $7.8 \%$ van de gevallen. ${ }^{144} \mathrm{Bij}$ de behandeling van prothese-infecties is het infectierisico groter. In de publicaties van het literaturoverzich (zie 9.3) worden gegevens daarover vermeld in 14 van de 40 publicaties over de radicale behandeling. Daarbij blijkt dat het infectiepercentage van de extra-anatomische bypass op de korte of lange termijn kan oplopen tot $22.0 \%$ en gemiddeld $12 \%$ te bedragen met een mediane waarde van $12.9 \%$.

De behandeling kan bestaan uit het aanleggen wan een nieuwe contralaterale bypass ${ }^{7}$ of een nieuwe bifurcatieprothese, met een betere hemodynamiek, eventueel vanaf de thoracale aorta ${ }^{75}$ of reconstructie van een nieuwe bifurcatie met behulp van de wena femoralis superficialis. Van deze latste behandeling zijn nog geen Jange termijn resulraren bekend. ${ }^{22}$ Een belangrijke vraag in verband met de plaatsing van een nieuwe abdominale vaatprothese ná behandeling van prothese-infecties betreft het tijdstip waarop deze reconstructie veilig kan plaatsvinden. Als er geen rekenen van retroperitoneale infectie meer zijn, is afhankelijk van de ard van het oorzakelijke micro-organisme, een jaar wachten warschijnlijk voldoende. ${ }^{75,112,267}$ Mogelijk is het ook verstandiger om voor de proximale anastomose een andere locarie dan de infrarenale aorta te kiezen en/of een andere positie dan her oude prothesebed. 75

\subsubsection{Cumulatieve lange termijn morbiditeit}

De behandeling van infecties wan abdominalle vatprothesen betekent een hoog risico. Her doel, effecrieve behandeling wan de infectie mer behoud van het leven en 
de ledematen, wordt in een aanzienlijk percentage niet bereikt. Tabel 2.12 geeft een overziche wan de gemiddelde morbiditeit bij de verschillende behandelingsvormen. Vooral bij oblitererend vaatijden is het aantal amputaties hoog. ${ }^{136}$ Insufficiêntie van de aortastomp is vrijwel altijd dodelijk en de behandeling van infectie en thrombose van de extra-anatomische bypass veroorzaakt opnieuw een eigen morbidireit en mortaliteit.?

Tabel 2.12. Owerzicht wan de gemiddelde lange termijn percentages morbidireit per behandeling in de literatum van her literatumroverzicht (9.3)

\begin{tabular}{llllll}
\hline Behandeling & amputaries blow out & $\begin{array}{l}\text { infectie } \\
\mathrm{eab}\end{array}$ & $\begin{array}{l}\text { thrombose } \\
\mathrm{eab}^{3}\end{array}$ & $\begin{array}{l}\text { gemidd duur } \\
\text { follow up }\end{array}$ \\
\hline radical & 19.8 & 13.7 & 12.0 & 23.9 & 33.0 \\
locaal & 14.7 & - & - & - & 35.0 \\
auroloog & 13.1 & - & - & $?$ & 15.4 \\
in situ & 4.6 & $14.0^{4}$ & - & $27.2^{2}$ & 27.5 \\
& & & & & \\
total & 15.7 & 13.6 & 11.2 & 24.6 & 29.3 \\
\hline
\end{tabular}

"wan de proximale anastomose; "van de reconstructie; "=extra-anatomische bypalss

\subsubsection{Persisteren van de infectie na niet-radicale behandeling}

Ondat sommige auteurs pas tot meer uitgebreide behandeling overgaan als chirurgische niet-radicale behandeling geen of onvoldoende succes oplevert ${ }^{88,126,197}$ is niet altijd exact te bepalen wanneer van mislukking van de niet-radicale behandeling moet worden gesproken. Nog minder is duidelijk hoe vaak deze handelwijze wordt toegepast en bij welke patiënten en op welke gronden wordt overgegaan naar een andere vorm van behandeling. ${ }^{36}$ In de literatuur van het literatuuroverzicht (appendix 9.3) wordt in 8 publicaries melding gemaakt van de frequentie van persisteren van de infecrie na chirurgische niet-radicale behandeling. De in deze publicaties opgegeven frequentie van een dusdanig gebrek aan succes van niet-radicale behandeling dat naar een andere vorm van behandeling werd overgegaan is gemiddeld $32.3 \%$, met een laagste opgave van $9 \% 215$ en cen maximum van $92 \% .136$ 


\section{Materiaal en methoden}

\subsection{PATIËNTEN}

In 11 Nederlandse ziekenhuizen, 6 universitaire en 5 perifere opleidingsziekenhuizen, werden retrospectief gegevens verzameld wan patienten die daar werden behandeld wegens een geinfecteerde arteriele abdominale vaatprothese. Hierbij werd abdominale vatprothese gedefinieerd als buisprothese in de aorta of als bifurcatieprothese, ongeacht of deze iliacaal of femoral werd aangesloten. De Stichring Informatiecentrum voor de Gezondheidszorg in Nederland (SIG) kent geen codenummer voor de diagnose 'geinfecteerde vatprothese' en er bestaat nog geen voor heel Nederland uniform registratiesysteem warin deze diagnose apart word vermeld. Daardoor is het niet mogelijk een selectie te maken via een gecomputeriseerd systeem. De selectie van patiënten met een geinfecteerde abdominale varprothese is derhalve uitgevoerd met behulp van een, in elk ziekenhuis verschillend, ter plaatse gehanteerd, coderingssysteem, dat in alle gevallen werd gerealiseend door de inspanningen van de behandelende chirurgen.

Gegevens berreffende deze 11 ziekenhwizen, de aantallen patienten die werden behandeld en de periode warover gegevens werden verzameld worden vermeld in tabel 3.1.

Varnwege de uitwoerbaarheid van het onderzoek waren de perioden waarover de patiëntengegevens werden verzameld niet voor alle ziekenhuizen dezelfde. Wel gat het per ziekenhuis, voor wat betreft de behandeling van de infectie van de abdominale vatprothese telkens om een anééngesloten periode (zic tabel). De perioden zijn wisselend van duur en het aantal pariënten per ziekenhuis is wisselend. De primaire operatie, dwa de operatie warbij de ecrste abdominale vat prothese werd ingebrache vond plats in een periode van 22 jaar tussen 1 januari 1972 en 1 januari 1994. De behandeling van alle infecties van de prothese vond plats in een periode van 13 jaar tussen 1 januari 1982 en 1 januari 1995.

Omdat het resultaat wan de behandeling van infecties van abdominale vaatprothesen, ondanks grote inspanningen nogal taleurstellend kan zijn en om desondanks zovel mogelijk betrouwbare resultaten te verkrijgen werd van meet af aan met de medewerkende chirurgen afgesproken dar ür de publicatie de gegevens niet nat behandelaar of ziekenhuis van behandeling herleidbaar zouden zijn. Er werden 97 
Tabel 3.1. Herkomst en arantealen behandelde patiènten

\begin{tabular}{|c|c|c|c|c|c|}
\hline ziekenhuis & $\begin{array}{l}\text { rocal } \\
\text { aantal }\end{array}$ & $\begin{array}{l}\text { eigen } \\
\text { pariëmen }\end{array}$ & $\begin{array}{l}\text { verwiezten } \\
\text { patienten }\end{array}$ & $\begin{array}{l}\text { werwigende } \\
\text { zekenhuizen }\end{array}$ & periode \\
\hline perifeer & 8 & 8 & - & - & $82-90$ \\
\hline perifeer & 8 & 7 & 1 & 1 & $85-94$ \\
\hline academisch & 27 & 17 & 10 & 6 & 82.93 \\
\hline academisch & 20 & 10 & 10 & 10 & $85-90$ \\
\hline periffeer & 15 & 9 & 6 & 6 & $83-90$ \\
\hline academisch & 10 & 7 & 3 & 3 & $86-90$ \\
\hline academisch & 6 & 4 & 2 & 2 & $84-88$ \\
\hline perifect: & 19 & 18 & 1 & 1 & $83-94$ \\
\hline academisch & 18 & 9 & 9 & 8 & $84-93$ \\
\hline acaddemisch & 16 & 8 & 8 & 6 & $89-94$ \\
\hline perifeer & 7 & 7 & - & - & $82-91$ \\
\hline toraal & 154 & 104 & 50 & & $82-94$ \\
\hline
\end{tabular}

patiënten behandeld in de 6 academische ziekenhuizen (gemiddeld 16 per ziekenhuis) en 57 patiënten werden behandeld in de 5 perifere opleidingsziekenhuizen (gemiddeld 11 per ziekenhuis). In totaal is dat 20.5 patiënt per jaar, en 1.9 patiënt per ziekenhuis per jaar. De 154 patiënten die in deze 11 chirurgische afdelingen werden behandeld voor een infectie van hun abdominale vaatprothese, ondergingen niet allen hun primaire operatie in diezelfde afdeling. Honderdvier paciënten werden voor de infectie van hun abdominale vaatprothese behandeld in thet ziekenhuis waar ook de primaire operatie had plaatsgevonden. Bij de 50 andere patiënten had de primairc operatie plaatsgevonden in 43 andere ziekenhuizen. De serie van 154 patiënten bestaat uit 137 mannen en 17 vrouwen, die ten tijde van de implantatie van de centrale vaatprothese een gemiddelde leeftijd hadden van 62.4 jarar (spreiding $19.3-81.5$ jaar).

\subsection{VERZAMELING VAN DE GEGEVENS}

Gegevens werden verzameld aan de hand van een standaard onderzoeksformulier bestaande uit drie delen, in chronologische volgorde: 1 . gegevens betreffende de primaire operatie, 2. het beloop in het interval tussen de primaire operatie en de taanifestatie van de infectie en 3 . de behandeling van de infectie van de abdominale vartprothese en het resultat van de behandeling. De informatie betreffende deze 3 perioden moest worden verkregen uit verschillende bronnen. De belangrijkste was her (centraal) klinisch pariëntendossier. Daarnaast bestond in een aanral klinieken een apart poliklinisch dossier, dat eveneens werd onderzocht. Voor 
zover beschikbaar werden de anesthesieverslagen, intensive care dossiers en verpleegkundige rapporten bestudeerd, die vaak belangrijke aanvullende informatie opleverden. Herzelfde gold voor de in enkele klinieken systematisch gemaakte verslagen van necrologiebesprekingen.

De originele rapportages van resultaten van röntgenonderzoek, laboraroriumonderzoek, microbiologisch onderzoek en andere aanvullende onderzoeken, waren niet altijd meer aanwezig. De gegevens konden in die gevallen vaak worden opgespoord uit de bovengenoemde bronnen. Obductieverslagen leverden in die gevallen waarin obductie werd verricht eveneens belangwekkende informatie.

Centraal stonden de operatieverslagen. De verslagen van de operaties die werden uitgevoerd ter behandeling van de infectie werden in alle gevallen opgespoord. Het verslag van de primaire operatie, die in sommige gevallen wrij lang geleden had plaatsgevonden, was in 11 gevallen $(7.1 \%)$ niet te achterhalen.

De essentiële gegevens met betrekking tot de primaire operatie konden in deze gevallen worden verkregen uit (combinaties van) ontslagbrieven, latere opnamedossiers en latere operatieverslagen. Voor zover na te gaan waren de gegevens over de operaties in her interval (zie 3.3.2) compleet.

De lange-termijn resultaten werden, voorzover ze niet uit het polikliniekdossier waren te herleiden, verkregen via telefonische en schriftelijke informatie bij de huisarts of de behandelende specialist.

Alleen met zekerheid bekende gegevens werden geregistreerd. Dubieuze of ongenoemde data of feiten waarover geen gegevens waren te verkrijgen, werden als onbekend of afwezig beschouwd.

De bij microbiologisch onderzoek gevonden bacteriën werden achteraf ingedeeld volgens categorieën genoemd in appendix 9.1. De verschillende gebruikte antibiotica werden ingedeeld in groepen op basis van hun pharmacologische eigenschappen, zoals weergegeven in appendix 9.2.

\subsection{DE ONDERZOCHTE VARLABELEN}

\subsubsection{DE PRIMAIRE OPERATIE}

Onder primaire operatie wordt verstan: de operatie waarbij de abdominale vaarprothese, (zie 3.1) waarvan de infecrie nader wordr bestudeerd, werd geimplanteerd. Geregistreerd werden: 


\subsubsection{Voorgeschiedenis}

\section{Comorbiditeit.}

Het bestan wan diabetes mellusus, het gebruik van steroiden, de anwezigheid van een stoma, her bestaan van necrose of gangreen aan de onderste extremiteit en andere in het dossier vermelde riektem.

\section{Chirturgische voorgeschiedenis.}

1. Voorafgande varoperaties in her aorro-iliacale en het femoro-popliteale raject.

2. De anwezigheid van litrekens in de lies wan voorgaande vatoperaties of andere ingrepen

3. De niet vasculaire abdominale ingrepen in het laatste jaar voor de primaire operarie.

\subsubsection{Indicatie}

De indicatie tot de primaire operatie werd verdeeld in:

1. aorto-iliacaal oblitererend vadijden

2. aorto-iliacaal aneurysmatisch vaarlijen

De indicatie werd nader gespecificeend door het onderscheid tussen acute operaties die onmiddellijk na opname werden verricht en geplande of electieve operaries.

1. Alle operaties waarvan de operateur vermeldt dar het gaar om cen geruptureerd aneurysnat werden als acuur geclassificeerd.

2. Alle andere operaties wegens aorto-iliacal aneurysmatisch of oblitererend vaatijden werden als elecrief gekwalificeerd

\subsubsection{De operatie}

Antibionische profylaxe. De profylactisch gebruikre antibiotica werden alle geregistreed en later ingedecld in de categorieèn zoals vermeld in appendix $(9.2)$.

Heparinsatie. Onderscheid is gemalkt tussen wel of geen systemische heparinisatie tijdens de primaire operatie, zonder werdere specificatie van doseringen.

Anastomosen. Voor de proximale anastomose op de abdominale aorta werd onderscheid gemaakt tussen:

1. end-ro-end anastomose

2. end-to-sidc surastomose

Voor de lokalisatie van distale anastomose(n) werd onderscheid gemaakt tussen:

1. de arta (buisprothese)

2. her iliacale raject (bifurcatieprothese)

3. het femonale traject (bifurcatieprothesey

4. combinatie van femoraal en iliacaal (bifurcarieprothese)

Prothesebedekking. De bedekking van de prothese en de afscherming ten opzichte van de angrenzende viscerale structuren, werd onderscheiden in: 
1. geen bedekling

2. bedzkking mer peritoneum

3. bedekling met aneurysmawand

4. bedekking met omentum majus

Wowddraws. Hierbij werden de wolgende mogelijkheden onderscheiden:

1. geen drains

2. intra-abdominale drain(s)

3. liesdrain(s)

4. abdominale en liesdrain(s)

Dwur wn de operatie. Hieronder werd de dun van de operatie in uren genoteend, zoals deze in het operarie- of anesthesieverslag was vermeld.

\subsubsection{Additionele operaries}

Onder 'additionele operaties" wordt verstaan: alle andere operaties die gelijkrijdig met de primaire operatie werden verricht.

\subsubsection{Peri-operatieve complicaties}

De problemen die zich tijdens de operatie voordeden en als zodanig in het operatieverslag waren vermeld, werden onderwerdeeld in twee groepen:

1. gegewens omtrent de algemene roestand wan de patiënt

2. operatief technische problemen

De eerste groep omvat gegevens over bloedverlies, shock en reanimatie. De problemen in de tweede groep werden alle apart geregistreerd.

\subsubsection{Microbiologie}

Waar thrombusmateriaal of debris uit een aneurysma werd gekweekt, werd de aard wan de gevonden bacteriën geregistreerd (voor classificarie zie 8.2).

\subsubsection{HET INTERVAL.}

Her interval is de periode tussen de primaire operarie en her tijdstip waarop de behandeling van de infectie van de abdominale vatprothese platswond. Her begin van her interval valt samen met de primaire operatie. Het einde wan het interval valt samen met her begin wan de behandeling van de infectie waaronder wordt verstaan: de operatie waarbij de prothese werd verwijderd of de laatste andere interventie ter behandeling van de infectie, warvan het resultat in deze studie word: beschreven. Het tijdstip wan diagnose is her rijdstip, waarop in het dossier duidelijk werd wermeld dat er sprake was van een infectie van de prothese. 
De geregistreade parientervariabelen in het interval werden werdeeld in 2 hoofdcategoriec̈n:

1. gegevens betreffende direct post-operatieve septische complicaties

2. gegewens betreffende chirugische reinterventies in het interval

As direct postoperatieve septische complicaties gelden alle infecrieuze complicaties die optraden rijdens de ziekenhuisopname of binnen dertig dagen na de primaire operatie. Tot de chirurgische reinterventies in het interwal werden gerekend: alle diagnostische en therapeutische operatieve ingrepen in die periode

\subsubsection{Postoperatieve infecties}

De wondinfecties zijn onderscheiden nat infecties van de abdominale wond en infecties wan de lieswond. De indeling volgens Szilagyi ${ }^{324}$ of de verdere onderverdeling van Szilagyi stadium III volgens Bunt ${ }^{37}$ was acheraf nier meer te maken. Gekozen werd voor overnemen van de beschrijving(en) zoals deze in het patiëntendossier werd(en) vermeld. Deze aanpak leidde tot de volgende omschrijvingen, waaronder ook mogelijk nier infectieuze wondgenezingsstoornissen:

1. oppervlakige infecrie

2. diepe infectie conservatief behandeld (pussende wond, alleen de hechringen verwijderd, gedeeltelifk of geheel geopend zonder narcose)

3. diepe infectie, operatief behandeld (is revens reïnterventie wegens septische complicatie)

4. fasciedehiscentie, nier operatief bethandeld

5. fasciedehiscentie, operatief behandeld (is tevens reinterventie wegens septische complicatie)

6. seroom: ophoping entof afscheiding van helder vocht, dat in her tossier niet als pus werd om schreven

7. fistel: ellk vocht of pus producerend defect in de wond dat geen spontane genezingstendens vertoonde

Van de andere post-operatieve infecties werden genoteerd de luchrweginfecties, urineweginfecties en het optreden wan sepsis.

Luchtweginfecties zijn voor dit onderzoek gedefinieerd als: de vermelding van infiltrat" of "pneumonie" of een uirslag van een positieve sputumkweek in het dossier. Urineweginfecties zijn voor dir onderzoek gedefinieerd als: de vermelding van 'urineweginfectic of een uitslag van een positieve urinekweek in het dossier.

Sepsis is gedefinieend als: koorts met koude rillingen, of koorts mer een positieve bloedkweek.

Bij het registreren achteraf wan deze infecties werd alleen een duidelijke vermelding van een diagnose of de aanwezigheid van positieve kweekuitslagen in het dossier als aanwezigheid van een septische complicatie geaccepteerd. Waar aanwezig, zijn de bacteriële kweekresultaten apart geregistreerd.

Zodoende ontstonden de volgende categorieen:

1. geen infecrie 
2. infectie zonder bekend kweektresultaat

3. infectie mer positief resultat wan cen kweek

\subsubsection{Reinterventies}

De reinterventies werden allereerst ingedeeld in 'vroege reinterventies en 'Late reinterventies". De vroege reinterventies behoren tot de morbiditeit van de primaire operatie. Onafhankelijk van de duur van de ziekenhuisopname werd een reïnterventie als "vroeg' gecodeerd als deze plaatsvond binnen dertig dagen na de primaire operacie.

Late reinterventies werden gedefinieerd als: alle ingrepen tussen dertig dagen na de primaire operatie en de operatie waarbij de infectie van de abdominale vaatprothese werd behandeld.

De 'vroege' en de 'late' reinterventies werden als volgt onderverdeeld en met de datum van de ingreep geregistreerd:

Rënterventies wegens septische complicaties. In deze groep werden ondergebrach alle drainages van abcessen, in de lies, abdominaal of retroperitoneaal, alsook enkele andere, elders gelokaliseerde, abcessen. Ook evacuatie van geïnfecteerde hematomen werd onder deze categorie gorangschikt. Operaties wegens 'buikwanddehiscentie' zijn ook in deze groep opgenomen, omdat een infectie hieran ten grondslag kan liggen. Bovendien kan een re-operatie voor secundaire sluiring wan een buikwanddehiscentie her infectierisico nadelig beinvloeden, 95 Operaties voor de diagnose 'aneurysma spurium' werden eveneens in deze groep ondergebracht, evenals tussenrijdse behandeling wegens aorto-enterale fistel, omdat infectie daarbij een oorzakelijke factor kan zijn 220

Reinternenties wegens bloedingscomplicaties. Hiertoe werden gerekend alle operaties wegens nabloeding of hematoom ter platse van de anastomose, of elders in de buik, retroperitoneaal of in de lies, zonder onderscheid cussen 'chirurgische' bloedingen en bloedingen als gevolg van (mogelijke) stollingsstoornissen.

Reinterventies wegens ischemische complicaties. Hieronder werden verstan alle ingrepen wegens thrombosering van (een van de benen vany de prothese, ongeache her type behandeling (thrombectomie, al dan niet gecombineerd met een prothese-interponaat of vervanging van de prothese of een deel ervan).

In deze groep werden ook de perifere afsluiringen door trombose of embolie, buiren het primaire operariegebied ondergebrach, ongeach of deze afsluitingen werden bethandeld door thrombecromie , perifere bypass, profundaplastick of een nieuwe anastomose. Hoewel "ischemische colitis" gewaardeerd kan worden als een "aandoening van de racrus digestiwus" werd deze afwijking ondergebrache in de groep "ischemische complicaties" ondat het in de eerste plaats een ischenim sche complicatie van de primaire operatie betreft.

Amputaties. Allecn de zogenaamde 'major' amputaries zijn vastgelegd: onder- en bovenbeensamputaries, amputaties door de knie en heupexarticulaties. 
Reinterventies wegens andoeningen van de tractus digestitws. Hierroe behoren alle operaties wegens post-operatieve ilews, ongeacht de behandeling (adhesiolyse of darmresectie) evenals alle operaties ande darm, operaties voor een 'second look' en exploratie wegens pancrearit is of operaties wan de galwegen. Enkelie liesbreukoperaties werden ook in deze groep ondergebrach. Operaries voor diagnostick en behandeling wan ischemische colitis werden geregistreerd bij 'ingrepen wanwege ischemische complicaties': de "second look" operaties hierna werden ingedeeld bij 'operaties wegens aandoeningen van de tractus digesrivus'.

Reinterventes wegens adndoeningen van de tractus urogenitalis. Deze groep bevat alle ingrepen na de primaire operatic aan de nieren, de ureteren, de blaas, de prostaac of de urethra. In de bestudecte parientengroep kwamen geen interventies wegens maligne andoeningen wan de tracrus urogenitalis voor. Cystoscopieèn of her inbrengen van suprapubische blaascatheters zijn nier geregistreend omdat deze ingrepen niet consequent in de dossiers waten geregistreerd.

Remterventies wegens andoeningen van de tractus respiratorius. Deze groep operaties beval uitsluitend tracheotomiečn. In de bestudeerde patièn tengroep zijn na de primaire operatie geen andere operaties aan de luch wegen verricht.

Reinterventies wegens maligne aandoeningen. In deze categorie zijn alle operaties wegens maligne aandoeningen ondergebracht, behalve die wegens maligne aandoeningen van de tractus digestivus, wellke onder 'rënterventies wegens aandoeningen wan de tractus digestivus' zijn ondergebracht.

Diversen. In deze groep werden opgenomen de dialyseshunt operaties en operaties die nier in een van de bovengenoemde groepen konden worden gerubriceerd.

\subsubsection{DE INFECTIE VAN DE ABDOMINALE VAATPROTHESE}

\subsubsection{Klinische presentatie}

Voor dit onderzoek is een indeling gemaakt, gebaseerd op de verschijnsellen die de patiënten met een infectie van de abdominale vaatprothese vertoonden op het moment van de opname in het ziekenhuis, tijdens welke de diagnose werd gesteld of de behandeling van de infecrie plats vond. Op basis van deze verschijnselen werd onderscheid gemaakt tussen de patiënten met specifieke klinische symptomen en de patienten met aspecifieke symptomatologie. 21

Op deze wijze kunnen drie categorieën patiërnten worden onderscheiden:

1. De eerste categorie wordt gevormd door de patiènten met specifieke linische afwijkingen in de lies die al bij een eerste fysisch-diagnostisch onderzoek aan het licht treden: een aneurysma (spurium), een abces of een niet genezen. wond, een fistel of een bloeding gelokaliseend in de lies ("local evidence of infection").

2. De tweede categorie bestatat uit die patiënten die zich presenteren met een bloeding uit de tractus digesrivus. 
3. De derde caregorie bestaat uit alle andere patienten met a-specifieke klachten en symptomen (systemic evidence of infection). In deze derde groep zijn alle patiënten ondergebracht die geen symptomen in de lies vertoonden en geen bloeding uit de tractus digestivus hadden.

Om enig inzicht te krijgen in de samenstelling van de derde categorie patiènten, is voor deze groep een onderverdeling gemaakt op basis van de nier specifieke verschijnselen of klachten:

1. koorts met koude rillingen, zonder andere klachten

2. buikklachten met 'défense musculaire',en/of koorts

3. koorts en malaise zonder buikklachten

4. vage klachten zonder seprische verschiinnselen.

Ter karakterisering van deze aspecifieke sympromatologie werden de volgende variabelen geregistreerd:

1. lichaamstemperatuur (geen koorts, koorts "koorts mer koude rillingen)

2. leucocytengetal (lager dan $10 \times 10^{6} / \mathrm{mm}^{3}$, russen $10 \mathrm{en} 20 \times 10^{6} / \mathrm{mm}^{3}$, tussen $20 \mathrm{en}$ $30 \times 10^{4} / \mathrm{mm}^{3}$, hoger dan $30 \times 10^{6} / \mathrm{mm}^{3}$ )

3. bezinkingssnelheid van de erythrocyten (BSE) lager clan 20 , tussen 20 en 50 , tussen $50 \mathrm{en}$ 100 , hoger dan $100 \mathrm{~mm} / \mathrm{uur}$

4. algemene "malaise"

Tot de aspecifieke symptomen werden ook gerekend:

Septische embolieën: In dit onderzoek wordt 'septische embolie' gedefinieerd als cen stroomafwaarts gelegen ontstekingsproces ten gevolge van het verslepen wan infectieus materiaal via de arteriële circulatie.

Sepsis e causa ignota. Sepsis wordt gedefiniecrd als koorts met koude rillingen of koorts thet een positieve bloedkweek.

\subsubsection{Diagnostiek}

Een prothese-infectie kan worden gedefinieerd als: het niet ingroeien van een prothese en/of de aanwexigheid van bacteriën en/of pus rondom enig deel van de prothese. (Lawrence 1995) De diagnose 'infectie' van de abdominale valarprothese kan gebaseerd zijn op het resultaat van lichamelijk onderzoek, op uitkomsten van diagnostische testen of de bevindingen bij operatie.

De volgende bevindingen bij operarie werden als bewijzend voor het bestaan van een infecrie beschouwd: 186,265

1. een open wond met een daarin zichtbare prothese

2. een in de darm zichtbare prothese

3. een positieve kweek van bij puncrie verkregen periprothetisch wocht of pus.

Bij operatieve exploratie werden de volgende bevindingen als bewijzend voor het bestaan van een infectie beschouwd:

1. het ontbreken van weefselingroei rond de prothese. 
2. een collectie vocht of pus rondom de prothese

Van de verschillende diagnostische restmechoden voor het opsporen van een infectie rondom een abdominale vaatprorhese werden de uitkomsten op gestandaardiseerde wijze geregistreerd. De standaard scoremogelijkheden voor deze onderzoeken waren:

1. niet gedaan of nict te vinden.

2. geen afwijkingen

3. bevindingen bewijzend voor de diagnose 'infectie van de abdominale vaatprorhese: vocht, pus en/of gasbeilten rondom de prothese worden beschouwd als bewrijzend voor het bestaan van een infecrie rondom de prothese."

4. bevindingen passend bij cen infectie van een abdominale vaatprothese, zoals intra-abdominaal of retroperitoneal wocht of abcessen.

Onderzocht werden de resultaren van:

1. Echografte: Aandacht werd besteed aan gegevens over (valse) aneurysma's ter plaatse van een anastomose ofvechtcollectie(s) rondom de prothese.

2. Computertomografee (CT): Gelet werd op de atnwezigheid van abnormale collecties van vocht, pus en/of gasbellen rondom deprorhese.

3. Magnetic resonance imaging (MRI): Hierbij werden dezelfde criteria voor het aantonen of uitsluiten van een infecrie rondom een abdominale vaatprothese gehanteerd als bij computertomografie. ${ }^{369,3.39}$

4. Sinografie: Als bewijzend woor de diagnose 'infecrie' werd beschouwd: de vrije verspreiding van contrastmid-del, vanuit een sinus, naar en rondom een of beide prothesebenern of het zichtbaar maken van een abcesholte, of cen fistel naar de aangrenzende viscerale strucruren. ${ }^{108}$

5. Gastro-duodenoscopie: Een in her lumen van de tractus digestivus zichrbare prothese werd aangennerkt als bewijzend voor de diagnose. Andere afwijkingen die steun konden geven aan her vermoeden van een infectie werden eveneens geregistreerd.

6. Colonoscopie: Hiervoor golden dezelfde criteria als voor de gastro-duodenoscopie.

7. Letcocytenscintigrafie (Indium111): De gevonden uirslagen werden gerubriceerd in de categorieën:

I geen afwijking

2 positicf centraal (aorra)

3 positicf unilateral (prochesebeen)

4 positief centraal en bilateraal (hele bifurcatieprothese)

8. Angiografie: De gevonden uitslagen werden gerubriceerd in de categorieën:

1 geen afwijkingen

2 oblivererende afwijkingen

3 aneurysma.

4 fistel 
9. Echo-geleide punctie en computertomografisch-geleide punctie: De verriche puncries en de kweekresultaren wan het verkregen materiaal werden geregistreerd. Eenpositief kweekre-

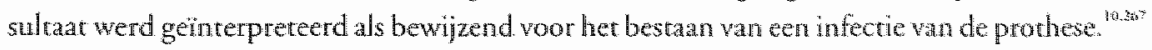
10. Microbiologie: De kweekresultaten van abdominale wonden, lieswonden en de bloedkweken ten tijde van dé presentatie van de infectic werden afzonderlijk geregistreerd.

\subsubsection{BEHANDELING VAN DE INFECTIE}

\subsubsection{Urgentie}

De behandeling krijgt een extra dimensie door de urgentie waarmee de patiënt werd geopereerd na de eerste presentatie of tijdens de opname. Richtlijn hiervoor was de beschrijving in her dossier. Her tijdsverloop tussen opname en operatie was meestal niet te achterhalen, maar an het tijdstip waarop de operatie werd uitgevoerd en de beschrijving in het operatieverslag of de anesthesielijst was dit gegeven meestal wel te destilleren. Twee categorieën werden onderscheiden:

1. Acuur: de operatie werd uirgevoerd als een nier geplande operatie

2. Elecrief: de operatie werd uitgevoerd in her normale geplande operatieprogramma na de dag van opname.

\subsubsection{Bevindingen bij operatie}

Ingroei van de prothese. De bevindingen zijn opgetekend volgens onderstaande omschrijving, op basis van hetgeen in het operatieverslag werd vermeld:

1. de prorhese is goed ingegroeid: deze mogelijkhteid werd alleen geregistreerd als dit expliciet in het operarieverslag werd vermeld

2. losliggende prothese: dezc omschrijving werd geregiscreerd als werd beschreven dat de prothese niet (goed) was ingegroeid of als werd vermeld dat de prothese los lag zonder andere mededelingen

3. wocht rondom de prothese: alle vormen van vloeistof rondom de prothese (termen als vocht" hemorrhagisch vocht", 'sereus vocht', in her operaricverslag werden hieronder gerangschikt)

4. pus rondom de prothese: werd allén geregistreerd als in her operatieverslag her woord 'pus' werd gebruikr.

De lokalisatie wan de arto-enterale fistels. Hiermee wordt aangegeven met welke viscerale of andere organen de prorhese een verbinding vormde, al dan niet gecombineerd met fisteling van deze organen naar de huid. Voor de aorto-enterale fistels waren er van oraal naar aboraal de volgende mogelijkheden:

1 duodenum

2 jejunum

3 coecum 
4 sigmoìd.

Andere fistel mogelijhbeden waren die noar:

5 blaas en huid

6 darm ton huid

7 ureter.

\subsubsection{Protheseverwijdering}

Bij het verwijderen van de prothese werd onderscheid gemaakt tussen een radicalle behandeling en een niet-radicale behandeling. (zie 2.7.1)

Onder radicale protheseverwijdering wordt verstaan het verwijderen van de gehele abdominale vaatprothese. Werd slechts een mancherje prothese op een van de anastomosen achtergelaten, dan werd de procedure toch als radicaal geregistreerd. De radicale behandeling was te onderscheiden in primair radicale en secundair radicale behandeling.

Met secundair radicale behandeling wordt bedoeld die situatie, waarin de behandeling in eerste instantie bestond uit niet, of niet-radicaal, verwijderen van de prothese, waarna wegens onvoldoende resultaat de prothese in tweede instantie alsnog radicaal werd verwijderd. Omdat het hier in feite gaat om mislukking van de "nietradicale" behandeling. werden deze patiënten in een aparte subgroep ondergebracht. De operaties die bij deze patiënten werden verricht alvòrens de prothese uireindelijk werd verwijderd, zijn ondergebracht bij de reïnterventies na de primaire operatie of in het interval.

Bij de niet-radicale behandeling van het prothese-infect werden twee mogelijkheden onderscheiden:

1. behandeling zonder protheseverwijdering

2. behancieling met parciêle protheseverwijdering.

Als na 'niet-radicale behandeling' alsnog werd overgegaan tot radicale protheseverwijdering, dan werden de voorgaande operaties, vóór radicale protheseverwijdering, geregistreerd als reinterventies in het interval.

De pariënten waarvoor, na het stellen van de diagnose, behandeling nier (meer) mogelijk of zinvol was werden ondergebracht in de categorie 'abstineren'.

\subsubsection{Behandeling van de aorta}

De mogelijkheden om de aortastomp, in geval van een eerdere end to end anastomose tussen prothese en aorta, te werzorgen werden als volgt geregistreerd:

1. cindstandig sluiten van de aortia

2. sluiren van een achrerblijvende kleine prothese-rest

3. suprarenaal sluiten van de zorta zonder revascularisatie van de nieren 
4. suprarenaal sluiten van de aorta met revascularisatie van de nieren

5. geen mogelijkheid om de alorta te sluiten

6. anastomose met een nieuwe prothese.

De mogelijkheden om de aortotomie, in geval van een eerdere end to side anastomose tussen prothese en aorta, ve verzorgen werden alls volgt geregistreerd:

1 primair sluiten van de aortoromie.

2 complere onderbinding van de aorta

3 een anastomose mer een nieuwe prothese.

Het gebruikte hechtmaterial bij her sluiten van de aortastomp werd onderverdeeld in:

1 resorbeerbaar hechtmaterial

2 niet-resorbeerbaar hechtmateriaal.

Als een mogelijkheid bestond om de aortastomp af te schermen ten opzichte van de buikorganen of getracht werd een bedekking te verkrijgen met vital en goed doorbloed weefsel, waren de volgende weefselstructuren te onderscheiden die daarvoor gebruikt konden worden:

- omentum majus (omentumplastiek)

- peritoneum

- aneurysmawand en/of littekenresten

- ligamentum longitudinale anterius.

\subsubsection{Behandeling van de darm}

Vanwege de diversiteit van de mogelijke wijzen waarop de darm behandeld kan worden, bij aorto-enterale of andere vormen van fisteling, werden alle toegepaste methoden apart geregistreerd.

\subsubsection{Revascularisatie}

Bij de revascularisatie van de onderste extremireiten werden drie belangrijke aspecten onderscheiden:

- het tijdstip waarop de revascularisatie plaatsvond

- de anatomische positie van het nieuw geconstrueerde vaattraject

- her materiaal dat werd gebruikt voor de nieuwe reconstructie.

In de internationale nomenclatuur is een aantal begrippen ingeburgerd dic ëen, twee of drie van deze aspecten omvatten. ${ }^{267}$

Omwille van de duidelijkheid en de vergelijkingsmogelijkheden zijn deze internationat. gehanteerde begrippen ook in dit onderzoek gebruikt bij de onderverdeling van de revascularisatiemethoden in zes categorieën: (zie ook 2.7.8.5)

1. geen revascularisatie 
2. extra-antomische rewascularisatie na het werwijcteren van de prothese in én doorgaande operatie: de zogenaamde "traditionele' behandeling

3. extra-anaromische revascularisarie vorafgaande aan het verwijderen van de prothese in én. door gaande operatic: de zogename "sequencial' behandeling

4. de zogenaande 'staged procedure': extra-anatomische reconstructie, warma in een rweede procedure enkele dagen later de prothese wordr werwijderd

5. de autologe reconstructic: daarbij wordt direct aansluitend aan het verwijderen van de prothese een reconstructie verriche mer auroloog material (ook genoemd "synchronous reconstruction")

6. de "in situ" revascularisatie, waarbij een nieuwe prothese wordt geplaatst in het bed van de verwijderde, geinfecteerde, prothese in én doorgande operatie.

Alle andere methoden van revascularisatie, zoals bij voorbeeld partiële revascularisatie na partiële protheseverwijdering zijn afzonderlijk geregistreerd.

\subsubsection{Microbiologie}

Genoteerd werden:

- de uitslag van het grampreparaat durante operationem

- her kweekresultaat wan de verwijderde prothese.

\subsubsection{RESULTATEN}

De resultaten van de chirurgische behandeling werden gekarakteriseerd door de morbiditeit, de complicaties en door de mortaliteit. Onderscheid werd gemaakt naar de classificatie van de prorhese-infectie en in vroege en late resultaten.

\subsubsection{Classificatie van de prothese-infectie}

Hieronder worde verstan de uiteindelijke diagnose of classificatie van de protheseinfectie zoals die is wastgesteld na behandeling. Indien er achtereenvolgens meerdere interventies an de prothese hebben platsgevonden, is het de diagnose die is gesteld bij de laatste behandeling van de infectie waarvan het resultaat in deze studie wordt beschreven.

Onderscheid werd gemaaks tussen twee classificaties. 37,38

1 Perigraft-infectie (PGI): een infectie rondom de abdominale vaatprothese zonder uitbreiding van deze infectie naar de tractus digestivus of andere omliggende organen of orgaansystemen.

2 Aorro-enterale fistel ( $\mathrm{EEF}$ ): een directe verbinding tussen enerzijds de abdominale vaatprothese, of de anastomose(n) en anderzijds de tractus digestivus. Ook aorto-ureterale en de aorto-entero-vesicalle fistels zijn hieronder gerangschilkt. 


\subsubsection{Vroege resultaten}

Mortaliteit. Als vroege mortaliteit werd gedefinieerd het overlijden binnen dertig dagen na de chirurgische behandeling of rijdens de ziekenhuisopname waarin de chirurgische behandeling van de prorhese-infectie platswond, ook indien deze langer dan dertig dagen duurde. Voor zowel de radicale als de niet-radicale behandeling werden geregistreerd:

I Her all dan niet opreden van wroege mortaliteir

2 De over levingsduur vanaf de behandeling van her prothese-infekr

3 De doodsoorzaak

Morbiditeit. Bij vroege morbidireit werden geregistreerd de algemene, de specifieke en andere complicaties die optreden binnen dertig dagen na de chirurgische behandeling van de infectie of vór ontslag uit het ziekenhuis als dit niet binnen dertig dagen plaatsvond. Onderscheiden werden de volgende algemene aspecten van de morbiditeit:

1 duur van de opname

2 duur van de intensive care verpleging

3 duur van de (eventuele) beademing

4 puimonale complicaties (pneumothorax, pneumonie)

5 cardiale complicaties (infarcr,decompensatio cordis)

6 neurologische complicaties (CVA's, insulren,verlammingen)

7 nierfunetiesroornissen (anurie, dialyse)

8 sepsis

9 multiple organ failure (MOF). Deze diagnose werd geregistreerd indien deze diagnose met zoveel woorden in het dossier werd vermeld en indien evident uit her dassier bleek dat meer dan één orgaansysteem progressief werd aangetast.

10 adult respiratory distress syndroom (ARDS) Als lijdende anu het ARDS werden geregistrectrd de pariënten waarbij deze diagnose in her medisch dossier met deze woorden was geregistreerd en daarnaast de patiënnen waarbij het bestaan van dit syndroom, zonder bijkomende andere diagnose(n), kon worden vermoed vanwege de langdurige beademing en de beschrijuing van onder andere thoraxforo's.

Van de specifieke complicaties werden apart geregistreerd:

1 ischemische complicaties: trombose van de extra-anatomische reconstructic, 'major' amputaries en ischemische colitis.

2 bloedingscomplicatics: abdominale nabloedingen en nablocdingen samenhangend met de extra-anatomische reconstructie, bloeding uit de tractus digestivus, stollingsstroornissen en insufficiêricie van de aortastomp (blow out).

3 infectieuze complicaries: infectie van de extra-anatomische reconseructie, infectieuzc complicaties van de kant van de buikorganen, wondinfecties en her optreden vans sepsis. 


\subsubsection{Late resultaten}

\section{Mortaliteit}

Van de patienten die na operatieve behandeling van de infectie het ziekenhuis levend konden verlaten werden de volgende gegevens geregistreerd:

1 De overlevingsduur wanaf de behandeling van het prothese-infekt

2 De doodsoorzaak

\section{Morbiditeit}

Bij de registratie van de late complicaties werden enkele specifieke complicaties geregistreerd die optraden na ontslag uit het ziekenhuis en die inzicht kunnen verschaffen in het succes van de behandeling en de 'quality of life' na behandeling van de protheseinfectie:

1 infecries van de extra-anatomische bypass

2 ischemie van de onderste extremiteiten met noodzaak van vasculaire reconstructies of amputaties

3 insufficiëntie ('blow our') wan de aortastomp

4 recidief aorto-enterale fistel

\subsection{DATA ANALYSE}

Nadar de gegevens waren verzameld werd de verdere analyse verricht met behulp van de PC-versie van het statistische programma Statistical Package for the Social Sciences, (SPSS) versie 5.0. Alle ontbrekende gegevens werden geclassificeerd als 'system missing value'. Statische analyse omvatten Students $T$-testen, $\mathrm{X}^{2}$-testen en life-table analysen. 


\section{Uitkomsten van het onderzoek}

\subsection{DE PRIMAIRE OPERATIE}

\subsection{DE VOORGESCHIEDENIS}

\subsubsection{Comorbidireit}

Aan diabetes leed $7.7 \%$ en $5.7 \%$ van de patiënten gebruikte steroiden. Necrose aan een of beide extremiteiten kwam voor bij $4.7 \%$. Gegevens over een reeds bestaand litteken in de lies ten tijde van de primaire operatie zijn bekend bij $141 \mathrm{par}$ tiènten (91.6\%), Twaalf patiënten $(8.5 \%)$ hadden een liesincisie van een voorgaande vaatoperatie. Drie patiënten $(2.1 \%)$ hadden een litteken in een lies ten gevolge van een andere oorzaak: een kogelverwonding, een verwonding door een granaatscherf en een lieskliertoilet wegens maligniteit, gevolgd door radiotherapie. Andere geregistreerde pre-existente aandoeningen waren: anus praeternaturalis (1), de ziekte van Boumeville (1), traumatische dwarslaesie met geinfecteerde decubitus (1), chronische peritoneaal dialyse (1), urethrastrictuur (1) en ernstige adiposiras (2).

\subsubsection{Voorafgande vasculaire operaties}

Gegevens over wel of niet voorafgegane vaaroperaties in het aorto-iliacale traject werden gevonden bij 139 patiënten (90.3\%).

Zeventien patiënten (12.2\%) ondergingen een vasculaire ingreep woordar de abdominale vaarprothese werd geïmplanteerd. Bij 7 patiënten was dit een abdominale ingreep, bij 7 patiènten was dit een niet abdominale vasculaire operatie. Bij 3 patiënten berrof het een transluminale angioplastiek in het iliacale traject, die in tén geval werd gecombineerd met een profundaplastiek.

De 7 abdominale vasculaire ingrepen aan het aorto-iliacale traject bestonden uit: een thrombendarteriëctomie van het iliacale traject (4), thrombendarteriëctomie van de aortabifurcatie met kunststof Y-plastiek (1), aorto-femorale bypass (1), exploratie van een aneurysma dat eerst inoperabel werd bevonden wegens proximale 
uitbreiding, waarna elders een infrarenale bifurcatieprothese, reikend tot in de lies, werd geimplantect.

\subsubsection{Recente abdominale operaties}

Recente andere abdominale operaties werden gezien bij 12 (8.6\%) van de 139 patienten warvan gegevens hierover konden worden gevonden.

Het betreft 5 operaties aan de tractus digesrivus, watran 2 wegens een maligne aandoening (maagcarcinoom, sigmoiddcatcinoom) en 3 operaties aan de tracus urogenicalis. Bij én patient werd cen portocavale shunt aangelegd wegens levercirrhose met oesophagusvarices, en een patiènt werd tot aan het moment van de primaire operatie behandeld met continue ambulante peritoneal dialyse. Twee pariënten ondergingen meerdere malen een buikwandplastiek wegens litrekenbreuken.

\subsection{INDICATHE}

Van de 154 patienten met een prothese-infecrie werden 91 patienten (59.9\%) geopereerd wegens een aneurysma van de aorta, warvan ongeveer de helft acuut (48.4\%). Een patiënt had mogelijk een mycotisch aneurysma, blijkens het feir dar hij pre-operatief reeds een septisch beeld vertoonde met postieve bloedkweken. Bij 2 pariënten kon de indicatic voor de primaire operatie niet goed geidentificeerd worden. Van de 61 patiënten (40.1\%) met obstruerend vatlijden werd én pariënt acu ut geopereerd.

\subsection{DE OPERATIE}

\subsubsection{Antibiorische profylaxe}

In 91 gevallen (59.1\%) was te achterhalen welke antibiotische profylaxe bij de primaire operatic was toegediend. In 63 gevallen (40.9\%) zijn hierover geen gegevens bekend. In 5 gevallen $(5.5 \%)$ is mer zekerheid bekend dat er geen antibiotische profylaxe is toegediend.

De antibiotica die profylactisch werden toegediend zijn weergegeven in tabel 4.1 . De grootste groep patiënten $(61.6 \%)$ kreeg als profylaxe monotherapie met een penicillinederivat danwel een cephalosporine. In $19.8 \%$ werd aan een van beide nog een aminoglycoside toegevoegd.

Profylaxe geticht op anaèroben in de vorm wan metronidazol werd slechts in $5.5 \%$ van de gevallen toegepast. De groep 'overigen' bevat een patiënt die een combinavie van lincomycine en kanamycine kreeg roegediend en drie patiënten die aen 
combinatie van drie antibiotica kregen wegens operaties aan het colon in de recente voorgeschiedenis.

Tabel 4.1. De antibiorische profylaxe bij de primaire operatie ${ }^{*}$

\begin{tabular}{lrr}
\cline { 2 - 3 } & $\mathrm{n}$ & $\%$ \\
\hline geen & 5 & 5.5 \\
penicillinen & 21 & 23.1 \\
cephalosporinen & 35 & 38.5 \\
quinolonen & 1 & 1.1 \\
macroliden & 1 & 1.1 \\
aminoglycoside + cephallosporine & 2 & 2.2 \\
amonoglycoside + penicilline & 16 & 17.6 \\
penicilline + cephalosporine & 1 & 1.1 \\
cephalosporine + metronidazol & 5 & 5.5 \\
averigen & 4 & 4.4 \\
total & & 100.0 \\
\hline
\end{tabular}

* zie appendix $(9.2)$

\subsubsection{Heparinisatie}

In $65.6 \%$ van de medische dossiers waren hierover gegevens te vinden. In driekwart van de goed gedocumenteerde gevallen werd systemisch gehepariniseerd $(75.2 \%)$. In negen gevalien ( $8.9 \%$ ) werd ook bij acure operaties systemisch gehepariniseerd.

\subsubsection{De prothese}

In geen der operarieverslagen werd melding gemaakt van ander prothesemateriaal dan dacron. In 10 gevallen kon nier met zekerheid worden vastgesteld of er proximaal cen end-to-end of een end-to-side anastomose met de aorta werd aangelegd. $\mathrm{Bij}$ de overige patiënten werd de proximale anastomose bij $1.8(81.9 \%)$ end- toend aangelegd en bij $26(18.1 \%)$ end-to-side. De localisatie van de distale anastomose(n) zijn aangegeven in tabel 4.2 . Bij 21 patiènten (13.7\%) bestond her implantaat uit een buisprothese. Het percentage patiënten met een bifurcatieprothese met beide distale anastomosen in tra-abdominaal was vrijwel gelijk aan dat met één of beide anastomosen in de lies. 
Tabel 4.2. De lokalisatie van distale anastomosen bij de primaire prothese-ïmplantatic

\begin{tabular}{|c|c|c|c|c|c|c|}
\hline \multirow[b]{2}{*}{ lokalisanic } & \multicolumn{2}{|c|}{ obstructief } & \multicolumn{2}{|c|}{ aneurysma } & \multicolumn{2}{|c|}{ rotaal } \\
\hline & $n$ & $\%$ & $n$ & $\%$ & $n$ & $\%$ \\
\hline aorcaal & 1 & 1.6 & 20 & 22.0 & 21 & 13.7 \\
\hline bi-iliacal & 19 & 31.1 & 46 & 50.5 & 67 & 43.8 \\
\hline bi-femotall & 28 & 45.9 & 18 & 19.8 & 46 & 29.4 \\
\hline femoral en iliacaal & 13 & 21.3 & 7 & 7.7 & 20 & 13.1 \\
\hline rovial & 61 & 100 & 91 & 100 & 154 & 100.0 \\
\hline
\end{tabular}

\subsubsection{Prothesebedekking}

De manier watop de prothese werd bedekt en afgeschermd ten opzichte van de naburige viscerale organen werd vermeld in 102 operatieverslagen (66.2\%). Bij 34 patiènten (33.3\%) werd aneurysmawand over de prothese gesloten en bij 59 patiënten $(57.8 \%)$ allén het peritoneum. Bij 9 patiënten $(8.8 \%)$ werd het omentum majus gebruikt om de prothese te bedekken.

\subsubsection{Drains}

Gegevens over het achterlaten van drains bij de primaire operatie werden vermeld in 60 operatieverslagen (39\%). Bij deze 60 patiënten werden 44 maal $(73.3 \%)$ zowel abdominaal als in de lies drains achtergelaten en 16 mal $(24.5 \%)$ alleen liesdrains.

\subsubsection{Duur van de operatic}

Dit gegeven wend 66 keer in het operacieverslag ( $42.8 \%$ ) vermeld: het minimum bedroeg anderhalf uur en de maximum operatietijd was 7 uur en 3 kwartier. De gemiddelde operatietijd bedroeg, evenals de mediane operatierijd, 4 ur.

\subsubsection{ADDITIONELE OPERATIES}

Her inbrengen van een suprapubische blaascatheter was in sommige klinieken bij implantatie van een centrale varprothese rourine, in sommige niet. Vermelding hiervan in operatieverslagen, ontslagbrieven of kweekuirslagen was zeer inconsistent en leverde geen betrowwbare gegevens op.

In 20 gevallen (13.0\%) werd tijdens de abdominale varoperatie, waatbij de prothese werd ingebracht, nog een andere ingreep uitgevoerd. Tegelijk met de primaire 
operatie werden 10 vasculaire reconstructieve ingrepen verricht. Daarnaast werd 3 maal een lumbale sympathectomie verricht en énmaal een prothese van een vorige reconstructieve ingreep verwijderd. Zes keer werd een niet-vasculaire additionele ingreep verricht. De additionele ingrepen zijn weergegeven in tabel 4.3.

Tabel 4.3. Addirionele operaties bij de primaire prothese implantarie

\begin{tabular}{ll}
\hline & $n$ \\
\hline Endarteriectomie iliacofemoraall & 3 \\
Verlengen van de prothese naar distal & 3 \\
Femoropopliteale bypass & 2 \\
Profundaplastiek & 2 \\
I.umbale sympathectomie & 3 \\
Verwijderen oude prothese & 1 \\
Appendectomic & 1 \\
Cholecystecromic & 1 \\
Exrirpacie para-aortale klieren & 1 \\
Correctie litrekenbreuk & 2 \\
Jejunumresectie en gaas verwijderen & 1 \\
totaal & 20 \\
\hline
\end{tabular}

\section{1 .5 COMPLICATIES}

Problemen bij de operatie deden zich voor bij 44 patiënten (28.6\%). Ennstige shock en groot bloedverlies werd bij tenminste 8 patiënten $(5.2 \%)$ vermeld. Een van hen werd rijdens de operatie 5 keer geresusciteerd. Adhesies, die volgens her operatieverslag problemen veroorzaakren kwamen voor bij 6 patiënten (3.9\%). Bij 2 patiênten werd vermeld dat het duodenum vast op de aorta gefixeerd was, waatdoor in één geval een duodenumletsel ontstond dat werd overhecht. Bij nog 3 patiënten werd in her operatieverslag een darmletsel beschreven dat overhecht moest worden. Problemen met de ureter, van dien aard dat deze in het operatieverslag werden vermeld, kwamen voor bij 3 pariënten (2\%); twee keer was de ureter zeer adherent aan het aneurysma en een keer werd de ureter zelfs geklield (en daarna weer gehecht). Eén patiènt bleek, naast een acrieve diverticulitis een geruptureerd aneurysma te hebben, waarbij desondanks een bifurcarieprothese werd ingehecht die primair werd bedekt met een omentumplastiek. Bij 14 patiënten $(9.1 \%)$ waren er technische problemen bij her inhechten van de prothese, variërend van problemen met de anastomose(n) rot het verlengen van een aanvankelijk ingehechte prothese terwijl 4 keer melding werd gemaakr van diffuse bloedingen die niet operatief te behandelen waren. Tweemaal bleek er bij operatie een groot retroperi- 
toneal hematoom anwezig dat in werband gebracht werd met een recente translumbale aonografie.

\subsubsection{MICROBIOLOGIE}

Het resultat van microbiologisch onderzoek van de aneurysma-inhoud verkregen tijdens de primaire operatie, werd gevonden voor 21 pariënten (23.0\% van de aneurysma's). Bij 14 pariènten bleef de kweek steriel. Zes maal (28.6\%) werd een positieve kweek gevonden: S aurew (1), S. epidemidis (2), S. epidermidis èn S. fatecalis (1), Enterocacen (1) en Klebsiella (1).

\subsection{HET INTERVAL}

\subsubsection{VROEGE SEPTISCHE COMPLICATIES}

\subsubsection{Wondinfecties na de primaire operatie}

De operatief behandelde wondinfecties binnen 30 dagen na de primaire operatie zijn ondergebracht bij de vroege reinterventies. (4.2.2) De niet operatief behandelde wondinfecries zijn onderverdeeld in infecties van de abdominale wonden en wan de lieswonden. (tabel 4.4 )

Tabel 4.4. Conservatief behandelde wondinfecties na de primaire operatie

\begin{tabular}{|c|c|c|c|c|}
\hline & \multicolumn{2}{|c|}{ abdominale wonden $n=113$} & \multicolumn{2}{|c|}{ lieswonden $n=50$} \\
\hline & $\mathrm{n}$ & $\%$ & n & $\%$ \\
\hline oppervlalakige infectic & 5 & 4.4 & 2 & 4.0 \\
\hline dicpe infectie & 7 & 6.2 & 3 & 6.0 \\
\hline fistel & - & - & 6 & 12.0 \\
\hline totatil & 12 & 10.6 & 11 & 22.0 \\
\hline
\end{tabular}

Duidelijke gegevens over her genezingsproces van de abdominale wond zijn beschikbaar van 113 patiènten (73.4\%). Van de 66 patiënten mer lieswond(en) waren gegevens over de wondgenezing beschikbaar bij 50 patienten $(75.8 \%)$. Gegevens over de ernst van de wondinfecties zijn gebaseerd op de soms vage mededelingen in ther dossier, en vaker nog, op de beschrijvingen in de werpleegkundige dossiers. In sommige dossiers staat niets vermeld ower de wondgenezing. Hetzelfde geldt voor nier infectieuze wondgenezingsstoornissen als seroom, lymf- 
fistel en fasciedehiscentie (cabel 4.5). Zes pariënten hadden wondinfecties, oq wondgenezingsstoornissen wan zowel de buikwond als de lieswond.

Tabel 4.5. Andere wondgenezingsstoomissen

\begin{tabular}{|c|c|c|c|c|}
\hline & \multicolumn{2}{|c|}{ abdominaal $n=113$} & \multicolumn{2}{|c|}{ lies $n=50$} \\
\hline & $\mathrm{n}$ & $\%$ & $n$ & $\%$ \\
\hline fasciedehiscentic & 2 & 1.8 & & \\
\hline seroorn & 2 & 4.0 & & \\
\hline lymffistel & 1 & 2.0 & & \\
\hline fortatat & 2 & 1.8 & 3 & 6.9 \\
\hline
\end{tabular}

\subsubsection{Andere post-operatieve infecties na de primaire operatie}

De opmerkingen die gelden voor de verslaglegging over wondgenezingsstoornissen gelden hier in nog sterkere mate. Veel informatie was slechts uitermate summier in de dossiers genoteerd. Gegevens moesten worden verkregen door combineren en deduceren van aantekeningen uit verpleegkundige rapporten, temperatuurlijsten en medicatielijsten. Alleen kweekuitslagen of expliciete vermelding in her dossier of ontslagbrief werden als 'harde' gegevens beschouwd. Als in de ontslagbrief werd vermeld dat het post-operatief beloop ongestoord was, werd dir gegeven geïnterpreteerd als afwezigheid wan infectie in de post-operatieve periode.

Het aantal patiënten met urineweginfecries, luchtweginfecties en sepsis en het aantal dat bij microbiologisch onderzoek werd bevestigd, zijn vermeld in de tabellen $4.6 \mathrm{t} / \mathrm{m}$ 4.9. (Zie voor indelingssystematiek appendix 9.1)

Tabel 4.6. Post-operatieve infecties en bacteriologisch onderzoek

\begin{tabular}{|c|c|c|c|c|c|c|}
\hline \multirow[t]{2}{*}{ post-operatieve infecties } & \multicolumn{2}{|c|}{ urinewegen. } & \multicolumn{2}{|c|}{ luch twegen } & \multicolumn{2}{|c|}{ sepsis } \\
\hline & $n$ & $\%$ & n & $\%$ & n & $\%$ \\
\hline informatie bekend & 99 & 64.2 & 103 & 668 & 107 & 69.5 \\
\hline annal infecries & 27 & 27.3 & 38 & 36.9 & 21 & 19.6 \\
\hline aancal kweekuitslagen & 26 & 26.3 & 25 & 24.3 & 23 & 21.5 \\
\hline
\end{tabular}


Bij de 19 kweken van de urine werden voomamelijk gram negatieve micro-organismen geidentificeerd (tabe) 4.7).

Tabel 4.7. Microbiologisch onderzock van de urine

\begin{tabular}{lcc}
\hline rnicromorganisme & $\mathrm{n}$ & $\%$ \\
\hline gram negatieve coccen. & 15 & 78.9 \\
S. atrems & 2 & 10.5 \\
S. epidermidis & 1 & 5.3 \\
fungi & 1 & 5.3 \\
& & \\
rotal & 19 & 100.0 \\
\hline
\end{tabular}

Bij de 23 kweken van het sputum bij patiënten die na de primaime operatie een luchrweginfecrie ontwikkelden werden voornamelijk gram negarieve micro-organismen gekweekt. (cabel 4.8)

Tabel 4.8. Microwbiologisch onderzoek van her spurum

\begin{tabular}{lcc}
\hline micro-organisme & $\mathrm{n}$ & $\%$ \\
\hline gram negatieve coccen & 18 & 78.3 \\
gram positieve coccen & 1 & 4.3 \\
gram positieven mer gram negatieven & 2 & 8.7 \\
S. atkremi mer gram negatieven & 2 & 8.7 \\
totaal & 23 & 100.0 \\
\hline
\end{tabular}

Bij de bloedkweken waren de gram negatieve micro-organismen in de minderheid. en bleken er meer staphylococcen aantoonbaar. (tabel 4.9)

Tabel 4.9. Microbiologisch onderzoek $y$ an thet bloed

\begin{tabular}{lcc} 
micro-organisme & $\mathrm{n}$ & $\%$ \\
\hline S. arwerw & 4 & 25.0 \\
S. epidermidis & 2 & 12.5 \\
andere gram posirieve coccen & 1 & 6.3 \\
gram negatieve coecen & 5 & 31.3 \\
anaeroben & 3 & 18.8 \\
S. epiderm mer gram pos coccen & 1 & 6.3 \\
& & \\
rotaal & 16 & 100.0 \\
\hline
\end{tabular}


Eén patiënt met een kweek van gram positieve coccen uit necrotisch weefsel van de voet $\mathrm{kreeg}$ wel een chirurgische wondinfecrie, waaruit cen ander micro-organisme werd gekweekt. Bij de 6 patiënten met een positieve kweek van de aneurysma-inhoud werd in geen van de gevallen hetzelfde micro-organisme in wond-, sputum-, urine-of bloedkweek teruggevonden.

Bij 3 patiènten met een wondinfectie werd herzelfde micro-organisme in de bloedkweek teruggevonden. Vier maal werd hetzelfde micro-organisme zowel in de urine als in het bloed aangetroffen; Bij slechts één patiènt werd in het sputum hetzelfde micro-organisme als in het bloed gevonden.

\subsection{VROEGE RETNTERVENTIES}

Er werden 76 vroege rë̈nterventies verricht bij 43 patiënten (27.9\%) binnen 30 dagen na de primaire operatie (tabel 4.12). Twintig pariènten ondergingen én vroege reinterventie, 15 patiënten ondergingen er twee, 6 patiënten drie, en 2 patiënten vier.

\subsubsection{De vroege reĭnterventies wegens infectieuze complicaties}

Infectieuze complicaties binnen 30 dagen na de primaire operatie, die tot re-operatie noopten, ontstonden bij 17 patiënten (11.3\%). Bij én patiënt ontstond een abcederende ontsteking ter plaatse van een infuus in de arm waarvoor operatieve drainage noodzakelijk was. De 16 septische complicaties (zie tabel 4.10 ) in het gebied van de operatie bestonden uit:

Vijf liesabcessen, waarman een gemfecteerd lieshematoom. Eén abces werd gepuncteerd, een werd geïncideerd, bij een werd een spoelsysteem ingebracht en bij een vierde werd een spierfascieplastiek verricht met achterlaten van gentamycinekralen. Het geïnfecteerde hematoom in de lies werd geëvacueerd.

Vier abdominale abcessen. Eén keer ging het om een geünfecteerd hematoom, dat werd behandeld door middel van evacuatie met achterlaten van een spoelsysteem. Hierbij ontstond een darm- en blaasletsel. Eén intra-abdominaal abces werd operarief gedraineerd en een ander werd gedraineerd mer behulp van computertonografische lokalisatie. Bij een patiënt ontstonden multiple intra-abdominale abcessen. Bij drainage ontstond een duodenumperforatie, waardoor na een mislukte omentumplastiek, een parrièle duodenumresectie noodzakelijk werd waarbij de duodenumstomp naar de buikwand werd gedraineerd en de maag over een drain eindstandig werd gesloten. Er volgde een relaparotomie voor een 'second look' waarna de volgende dag de prothese werd verwijderd wegens een 'bloeding' achter de maag. Dit alles binnen drie weken na de primaire operatie.

Twee retroperitoneale abcessen. Deze werden wia een flankincisic gedrainecrd. Vijf buikwanddehiscenties. Hiervoor werd secundaire sluiting verricht. 
Tabel 4.10. Vroege reinterwentes wegens infectieuze complicaties

\begin{tabular}{|c|c|c|c|}
\hline & abdominaal & lies & overige \\
\hline abces lies & 4 & & \\
\hline intra-abdom abces & 3 & & \\
\hline genfecteerd hematoom & 1 & 1 & \\
\hline retroperitoneal abces & 2 & & \\
\hline buikwanddehiscentie & 5 & & \\
\hline abces an & & & 1 \\
\hline rocal & 11 & 5 & 1 \\
\hline
\end{tabular}

\subsubsection{Microbiologisch onderzoek bij de vroege septische complicaties}

Het kweekresultaat van de geinfecteerde wonden kon worden getraceerd bij 16 van de 17 operatief behandelde patiënten. Zes maal was S. awreus cen van de veroorzakende micro-organismen en drie maal S epiderwidis (tabel 4. 11).

Tabel 4.11. Resultaten wan het microbiologisch onderzoek wan de geinfecteende wonden

\begin{tabular}{|c|c|c|}
\hline micro-organisme & n & $\%$ \\
\hline S. anwerbs & 3 & 18.8 \\
\hline S. axrews + gram negatieven & 2 & 12.5 \\
\hline S. whrets + andere gram pos of gram neg & 1 & 6.3 \\
\hline Sepidenridis & 2 & 12.5 \\
\hline Sepiderwidis + anaèroben & 1 & 6.3 \\
\hline gram negatieve coccen & 4 & 25,0 \\
\hline aniäroben & 1 & 6.3 \\
\hline gram positieven , gram negatieven & 1 & 6.3 \\
\hline anacroben + gram pos of gram neg. & 1 & 6.3 \\
\hline ronal & 16 & 100.0 \\
\hline
\end{tabular}

\subsubsection{De vroege reinterventies wegens bloedingsicomplicaties}

Wegens bloedingscomplicaries waren bij 10 patiènten $(6.5 \%)$ binnen dertig dagen na de primaire operatie 13 re-operaties noodzakelijk.

Zes keer werd slechss een hematoom geèvacueerd, rweemaal moest daarbij een letsel van de linker nicrvene worden overhech en eennal werd darbij een splenectomie verricht. Bij een pa- 
tièn werd een iatrogeen lersel van her mesenterium van de dam owerhecht. Eennal moest zowel de proximale als de distale anastomose wan de prothese worden ovehecht en een mal moest een geheel nieuwe anastomose in de lies worden gemaakt. In een geval bestond zowel een afsluiring van een been van de prohese als een nabloeding op de nadd. Drie van deze patiènem noesten rweemaal geréopeerd worden wegens nabloeding.

\subsubsection{De vroege reïnterventies wegens ischemische complicaries}

Ischemische complicaties ontstonden 21 keer binnen dertig dagen na de primaire operatie. Het betreft 18 patienten (11.7\%), warvan 3 een perifere ischemie hadden, 13 een trombose van een prothesebeen en 2 een ischemische colitis. Wegens bloeding én arteriële thrombose vonden er in total 34 vroege arteriele reinterventies plaats bij 27 patiënten.(17.5\%)

In verband met de perifere ischemie kon een keer worden wolstaan met cen cenvoudige thrombecromie, een keer moest een femorodisalie bypass worden aangelegd en cenmaal moest een bestaande femoropopliteale bypass worden gereviseerd.

Bij de 13 pariënten mer rombose van een prothesebeen kon 8 keer een gewone thrombectomie worden werricht. Naast deze thrombectomie moest bij éen pariènt her prothesebeen wor den verlengd en werd tweenaal de thrombectomie gevolgd door een perifere bypassoperatic en eenmal door een iliacale bypass. Bij een andere werd na de thrombectomie tevens fascioromie van de spierloges van het onderbeen verticht.

Na de primaire operatie ontstond wee maal ischemische colicis. Hiervoor werd bij de ene patiënt een siggmoïdresectie volgens Hartmann werricht, terwijl bij de ander een torale colecromite noodzakelijk was. Drie pariënten werden rwee mal wegens ischemische complicaties geopereerd.

\subsubsection{De vroege amputaties}

In de post-operatieve fase na de primaire operatie werd bij 3 patiénten $(2 \%)$ ven amputatic noodzakelijk: 2 bovenbeensamputaties en een amputatic door de knie. Een patiën was eerder geréopereend wegens afsluiting van een protheseben, de tweede wegens alshiting van een prothesebeen met nabloeding en de derde onderging thrombectomite van en prothesebeen gecombineerd met een femorocruale bypass, warna een dag larer fasciotomie wan de onderbeensmusculatuur werd werriche, hergeen na multiple necrotomieèn uireindelijk resulteende in een knic exarticulatie

\subsubsection{De vroege rë̈nterventies wegens aandoeningen van de tracus digestivus}

Negen re-operaties bij 8 pariënten $(5.2 \%)$ waren noodzakelijk wegens andoeningen van de tractus digestivus na de primaire operatic. De eerste operatie wegens 
ischemische colitis werd meegeteld bij de ischemische complicaties, de 'second look' operaties na deze complicatie werden ingedeeld bij 'tractus digestivus'.

Bij 3 patiénten werd wegens ileus een laparotomie met adhesiolyse verricht. Bij een pariënt werd een exploratie met drainage van een pancreaspseudocyste verricht en bij een patiënt werd een duodenumperforatie owerhecht, warbifi tewens een omentumplastiek werd aangebracht.

Een patünt, die al tweemaal ecrder werd geopereerd wegens een nierveneletsel en evacuatie van een hematoom, werd ook nog eens wegens een maagbloeding geopereerd. Een patiènt, waarbij eerder een mesenteriumletsel van de darm werd overhecht, moest een dunne darmresectie ondergaan. Twee patiênten ondergingen een 'second look' operatic Bij een 'second look' werd een drainageprocedure wan de peritonealtholte verrichr met spoelen. Bij een patiënt met torale colectomie wegens ischemische colitis werd een 'second look' verricht met achrerlaten van gentamycinekralen bij de prothese.

\subsubsection{De vroege reïnterventies wegens aandoeningen van de tractus urogenitalis}

Er was één vroege ingreep aan de tractus urogenitalis in de vorm van een operatieve ureterdilaratie wegens ureterstenose, welke in een later stadium zou worden gereseceerd.

\subsubsection{De vroege reïnterventies wegens aandoeningen van de tractus respiratorius}

Er waren geen andere ingrepen aan de luchtwegen dan vijf tracheotomieën vanwege de noodzaak tot Janger durende beademing.

\section{4,2.2.9 De vroege reïnterventies wegens andere aandoeningen}

Een patiënt met een letsel van de arteria subclavia werd eerst voor een acute afsluiring van de arteria brachialis geopereerd. Later kreeg hij een mycorisch aneurysma van de arteria subclavia dat, wegens ruptuur, werd vervangen door cen veneus interponaat.

De 6 andere ingrepen in deze groep zijn operaties voor het aanleggen van dialyse shunts: vijf Scribner shunts, waarvan een later werd vervangen door een Brescia Cimino shunt.

Samenvattend waren in deze serie van 154 patiënten bij 115 patiënten $(76.7 \%)$ pre- per- of postoperatieve complicaties of factoren die kunnen bijdragen aan het ontstaan van een infectie. Slechts 39 pariënten hadden geen achterhaalbare complicaties rondom of na de primaire prothese implantatie. 
Bij 51 patiënten (33.1\%) waren er reeds pre-operarief risicofactoren aanwezig in de zin van reeds bestaande afwijkingen en ziekten, voorgaande abdominale (vaat)operaties of gangreen aan de extremiteiten.

Bij 82 patiënten (53.2\%) waren er peroperatieve problemen of risicofactoren als: acute operatie, additionele ingrepen, technische problemen en bloedings- en stollingscomplicaties. Voor een deel waren deze factoren medeoonaak van de postoperatieve complicaties die bij 76 patiënten ( $49.4 \%$ ) bleken op te treden en die bij 43 patiënten (27.9\%) aamleiding waren voor 76 vroege reinterventies, watran 17 wegens seprische complicaries. (zie tabel 4.12 )

Tijdens de primaire operatie waren er bij 28 pariènten (18.2\%) problemen (adhesies, recente abdominale operaties, status na radiotherapie) die tor darm- of ureter-letsel leidden of anderszins de operatie bemoeilijkten of een potentiele contaminatiebron vormden (anus preternaturalis, achtergebleven gaas of oude prothese, para-aortale klieruitruiming, diverticulitis, CAPD catheter). De oorzaken voor deze groep complicaties kan worden samengevat onder de ritel 'hostile abdomen" Als alle voorafgaande abdominale vaatoperacies (7) worden meegeteld was er bij $22.7 \%$ van de patiënten in deze serie sprake van een "hostile abdomen".

Bij 75 pariënten (48.7\%) werden wroege infectieuze complicaties gezien, (wondinfecties, Juchtweginfecties, urineweginfecties of sepsis) zonder significant verschil tussen acute en electieve operaties.

Tabel 4.12. Overzicht aantallen en redenen voor de vroege reïnterventies.

\begin{tabular}{lccc}
\hline reinterventie wegens: & $\mathrm{n}$ & patiënten & $\%$ van alle patiënten \\
\hline infectieuze complicaries & 17 & 17 & 11.0 \\
bloedingscomplicaries & 13 & 10 & 6.5 \\
ischemische complicaties & 21 & 18 & 11.7 \\
ruajor amputaties & 3 & 3 & 2.0 \\
operaties aan de tracus digestivus & 9 & 8 & 5.2 \\
alandoeningen van de tractus urogenitalis & 1 & 1 & 0.6 \\
ingrepen aran de tractus respiratorius & 5 & 5 & 3.2 \\
diversen & 7 & 7 & 4.5 \\
& & & \\
total & 76 & 43 & 27.9 \\
\hline
\end{tabular}

* sommige parienten hadden meerdere complicaties 
In de periode tussen de primaire operatie en het tijdstip van de diagnose 'geinfecreerde abdominale vatprothese (het interval) vonden in total 243 operatieve ingrepen plats bij 92 patiénten $(59.7 \%)$. Operaties vanwege de complicaties van de reinterventies zelf zijn hierbij inbegrepen. De cotalen van alle late reinterventies in het incerval zijn samengevat in tabel 4.16.

\subsubsection{De reinterventies wegens infectieuze complicaties in het interval}

Onderscheid is te maken tussen zeker septische en mogelijk seprische complicaries. Operaties wegens aneurysma spurium en littekenbreuk werden tot de mogelijk septische complicaties gerekend. Daarnaast zijn er ingrepen wegens seprische gebeurtenissen, die mogelijk (mede) oorzak of gevolg kunnen zijn van de prothese-infecrie. Dit onderscheid is echter niet in alle gevallen even duidelijk. In totaal werden in verband met mogelijk infectieuze complicaties bij 65 patienten (42.2\%) 109 reinterventies verricht. (tabel 4.13)

Eén reinterventie wegens infectie ondergingen 39 patiënten, 15 patiènten ondergingen wwee, 5 pariënten drie, 5 patiènten vier en cén patiënt vijf re-operaties.

Eenendertig manl werd cen abces in de lies gediagnostuseed, bij 5 patiënten rweemaal, en 2 parienten 3 keer. Tweemaal werd explicier vermeld dat de prothese bloot lag in het abces.

Bij de groep mer intra-abdominale abcessen hat één patën twee keer een intra-abdoninaal abces. Een patiën had beiderijds een aneurysma spurium en daarna een liesabces. Twee paciennen hadden tweemal een aneurysma spurium in de lies. Bijén pariènt met een aneurysma spurium in de lies werd warmeld dat het om een geabcedeerd wals aneurysma ging.

Driemaal werd bij eenzelfde pariènt een zwelling in de lies geopend onder de diagnose 'cyste', Hierbij kwam helder vocht tewoorschiin, warvan de bacreriologische loweek steriel bleek, war na meerdere femoropopliteale reconstucties werden verricht, totdat zich aiteindelijk een aorwerererale fistel openbarde.

De rubriek 'andere abcessen' bewat onder meer 2 gluteale abcessen. Bij én patiënt mer een glureat aboes moes later nog een aboes in her been worden gedraineerd. De vier andere waren em. bolische abcessen.

De 8 patrienten met een aorto-chterale fised en de parient met de aorto-ureterale fistel zijn hier vermeld ondat zij annvankelijk symptonaciseh werden behandeld, waana later nog een verdere behandeling zou volgen. $Z$ ij behoren dethalve rot de groep 'secundair radicaal" behandelde patiënten. Reinteventies wegens aneurysma spurium in het interval, werden 34 mal verricht bij 26 paciërnen. Erwaren 4 parienten die in het interval werden behandeld wegens een nadaneurysma ter hoogte van de proximale anastomose van de bifurcatieprorhese.

Driemaal bestond de behandeling uit een prothese interponat en eenmal werd een nieuwe proximale naad gemalake (evenals distaal), Bij cen van de patiènten mer een prothese interponaat ontstond een duodennwietsel, dat werd overhecht en bedekt door een omentumplastick. 
Tabel 4.13. Owericht van de operatief behandelde late septische complicaties in het interval bij 65 patänten

\begin{tabular}{|c|c|c|}
\hline abcessen en fistels & \multicolumn{2}{|c|}{ andal operaries } \\
\hline abces in de lies & \multicolumn{2}{|l|}{31} \\
\hline sinus in de lies. & \multicolumn{2}{|l|}{4} \\
\hline 'oysre' in de lies & \multicolumn{2}{|l|}{3} \\
\hline incra-abdominaal abces & \multicolumn{2}{|l|}{5} \\
\hline retroperitoneaal abces & \multicolumn{2}{|l|}{6} \\
\hline andere abcessen & \multicolumn{2}{|l|}{7} \\
\hline aorro-enterale fistel & \multicolumn{2}{|l|}{8} \\
\hline aorto-ureterale fistel & \multicolumn{2}{|l|}{1} \\
\hline roraal & \multirow{2}{*}{\multicolumn{2}{|c|}{65}} \\
\hline aneurysma's & & \\
\hline aneurysma spurium in de lies & \multicolumn{2}{|l|}{23} \\
\hline gerupureerd aneurysma spurium in de lies & \multicolumn{2}{|l|}{5} \\
\hline aneurysma spurium abdominaal & \multicolumn{2}{|l|}{6} \\
\hline totaal & & 34 \\
\hline \multicolumn{3}{|l|}{ diversen } \\
\hline litrekenbreuk & \multicolumn{2}{|l|}{8} \\
\hline geinfecterde heupprothese & \multicolumn{2}{|l|}{1} \\
\hline drainrest & \multicolumn{2}{|l|}{1} \\
\hline rotaxl & & 10 \\
\hline totaal & 109 & 109 \\
\hline
\end{tabular}

Bif twee patienten was het abdominaal nadaneurysma op her iliacale niveau getokaliseerd. Her ene naadaneurysma werd behandeld door een prothese incerponate en het andere uirgeschakeld door onderbinding.

Er waren 10 pariënten met een eenzijdig anastomoseaneurysma in de lies. Zij werden behandeid door middel van een prothese interponaar (7), een nieuwe anastomose (1), wen profundiplastick (1), en een nieuwe femoro-distale bypass.

Vier patienten thadden een nadaneurysma in beicle liezen. Twee van deze patienten kregen aun beide kanten een prothese interponat mer en tussen poos var resp 6 en 10 mander. Een ander kreeg aan de ene kant een prothese interponaat en zes weken later aan de contra-lattralk zijde een weneus interponaat. Van de vierde is de behandeling nier met zekerheid bekend; mer en russenpoos wan 4 jar en drie manden kreeg hij waarschijnlijk beideraijds een prothese interponaat. Dric patienten die al cerder waren behandeld woor een proximalan ancurysma werden alle drie in rweede instancie woor een distal nadaneurysma in de lies geopereerd na I mand, 22 maanden en 36 maanden. Bij de eerste werd cen protheseben verwijderd wama een femoro-fomorale 
cross-over bypass werd aangelegd, bij de wee anderen werd het aneurysma vervangen door een. prothese interponat.

Bij een patiënt ontstond een recidief anastomoseaneurysma dat, nadar in eerste instantie een dacronprothese was geinterponeerd, werd behandeld door middel wan een veneuze path

Bij de 5 patiénten met een gerupureerd naadaneurysma in de lies werd al direct rekening gehouden met ecn prothese-infectie:

Bij cen wan dexe patiènten werd cen (geinfecteerde 3) bypass uit het bowenbeen verwijderd waarna, na en abcesdrainage, een bovenbeensamputatie volgde. Bij cen ander werd alleen her hematoom uitgeruind on verdere diagnostiek naar infectie van de prothese te verrichten, waar men echrer niet meer an toe kwam wegens cen blooding.

Tweemal werd een prothesebeen verwijderd en eenmaal onderbonden relkens met aanleggen van een extra-anaromische bypass.

Acht pariënten werden geopereerd wegens een litrekenbreuk.

Bij een patiënt moest een drainrest worden verwijderd wegens 'buikdlachren".

Deze patièn onderging een sigmoidresectie wegens diverticulitis, waarna vier maanden larer het colon werd gerćanastomoseerd. Bij deze operarie kwam de prothese reeds a vue. Weer vijftien maanden later werd onrdekt dat na de sigmoidresecrie een drain was achrergebleven waaromheen zich cen abces had gevormd. De drain werd verwijderd en het abces gedraineerd. Drie maanden na deze laatste operatie werd een psoasabces gediagnostiseerd.

Bij cen andere patiënt werd, 2 maanden woordat er een zorto-enterale fistel werd vastgesteld, cen geinfecreerde heupprothese verwijderd.

\subsubsection{Reinterventies wegens bloedingscomplicaties in het interval}

Er waren 4 patiënten $(2.6 \%)$ die in het interval werden geopereerd wegens een acute bloeding.

Een parienn had een acute bloeding met drie liter bloed in de vrije buikhol te zonder dat een oorzaak werd gevonden; 4.3 jakar later manifesteerde zich een AEF. Eén patiënt had een hemaroom in de lies nadat twee keer een angiografie was werricht. Het hematoom werd geẻvacueerd en er werden gentamycine-kralen achtergelaten. Bij de derde patient werd een laparotomie verricht wegens een hoge tractus digestivus bloeding. Er werd gezoche natar een aorto-enterale fistel, die op dat moment nier wetd gevonden, maar vier maanden later wel. De vierde patiënt moest wegeas een nablooding in her mesocolon worden geopereerd, op de dig van vervanging van een vals ancurysma, ter plantse wan de distale anastomose van cen aortobi-iliacale bifurcatieprothese door en prothese-interponat.

\subsubsection{Reinterventies wegens ischemische complicaties in het interval}

Er waren in totaal 58 re-operaties bij 31 patiënten (20.1\%) noodzakelijk wegens ischemische problemen in het interval. Dertien patiënten ondergingen één operatie, 8 patiënten twee, 3 patiënten drie, één patiënt vier en 3 patiënten ondergingen 
wijf reïnterventies wegens ischemische afwijkingen tijdens her interval. De réoperaties wegens ischemische complicaties zijn samengevat in rabel 4.14 .

Tabel 4.14. Reünterventies wegens ischemische complicaties in her interval bij 31 patianten

\begin{tabular}{lc}
\hline operatie & n \\
nieuwe bifurcatieprothese & 5 \\
thrombectomie prothese beiderzijds & 2 \\
thrombectomie van een prothesebeen & 7 \\
thrombectomie rnet verlengen & 3 \\
vervangen van een prothesebeen & 1 \\
verwijderen van een prothesebeen & 2 \\
thrombectomie met perifere reconstructie & 5 \\
perifere thrombectomie & 5 \\
femoropopliteale bypass & 15 \\
profundaplastiek & 3 \\
andere perifere reconstructies & 10 \\
total & 58 \\
\hline
\end{tabular}

In total ontstonden bij 17 patiënten (11.0\%) 25 thrombosaringen van de prothese. Bij 4 pam tiënten werd wegens thrombose 5 keer een nieuwe prothese ingebracht en bij een patient on dezelfde reden tweemal een dubbelzijdige thrombectomie verricht.

Bij 12 paciënten ontstond 18 mal een afsluiring van één been wan de bifurcatieprothese. Zeven. keer werd hiervoor een thrombectomie verricht, tweemal werd een prothesebeen verwijderd en en keer vervangen. Driemaal werd na desobstructie her prothesebeen met prothese verlengd en bij een patiènt werd na desobstructie de distale anastomose verwijd met behul wan cen veneuze patch. Vier keer werd gelijkrijdig mer de desobstructie de perifere outflow verbeterd door middel wan een perfifere reconstructie:

Wegens perifere afwikingen werd wijt keer een perifere thrombectomie vervicht, drimal cen profundaplastiek en 15 keer een femoropopliteale bypassoperatie bij 14 patiönten. Twee partenten ondergingen wijfmaal een perifere reconstructie.

\subsubsection{Amputaties in het interval}

In het interval werden bij 6 van de 154 patiënten (5.2\%) in total 8 "major" amputaries verricht: 3 bovenbeensamputaries, 2 onderbeensamputaties en én 'through knee'-amputatie. Bij 2 patiënten die eerder al een bovenbeensamputatie hadden ondergaan, moest eenmaal een bovenbeenstomp worden ingekort en eenmal een heupexarticulatie worden verricht. 
4.2.3.5 Reinterventies wegens aandoeningen van de tractus digestivus in her interval

In het interval werden bij 19 pariënten $(12.3 \%)$ wegens aandoeningen van de tractus digestivus 24 operaties uirgevoerd (tabel 4.15 )

Tatbel 4.15. Operaties an de tractus digestivus in her interval bij 19 patiënten

\begin{tabular}{|c|c|}
\hline aard cn annal wan de operanies & $\mathrm{n}$ \\
\hline adhesiolyse wegens lleus & 2 \\
\hline dunne darmresectie bij ileus & 5 \\
\hline colonresectic & 2 \\
\hline maagoperatice & 2 \\
\hline operaties an galblas en galwegen & 5 \\
\hline appendecromic & 3 \\
\hline aanleggen of opheffer anus preternaturalis & 3 \\
\hline liesbreukoperanic & 2 \\
\hline toral al & 24 \\
\hline
\end{tabular}

4.2.3.6 Rë̈nterventies wegens aandoeningen wan de tractus urogenitalis in het interval

In total werden in het interval 22 operaties verricht wegens aandoeningen wan de tractus urogenitalis bij 13 pariënten ( $8.4 \%$ ).

Er waren 6 ingrepen aan de lagere urinewegen: een circumcisie, een supra-pubische carheter gevolgd door urethradilacacie, wwee transurethrale prostatectomieèn en een prostaatpunctie wararbij een koude rilling op trad.

In total was er 10 keer een ureterobstructie en twee keer ureterlekkage, waarvoor zes keer nefrecromic, driemal ureterdilatatic, ben ureterolyse, en tweemaal klieven mer re-anastomosering werd werricht. Driemaal werd en nefrostomie angelegd. Bij een pariènt werd na nefrectomie wegens ureterobstructie cen blasplastiek uirgevoerd wegens een urinefistel naar her sigmoid en de lies. Later bleek een samenhang met de geïnfecteerde prothese.

\subsubsection{Reinrerventies wegens maligne aandoeningen in het interval}

Er waren 5 pariénten die in het interval tussen de primaire operatie en de diagnose 'infectie van de prothese' een maligne aandoening ontwikkelden, waarvoor zij in totaal 12 operaties ondergingen.

Het betrof een commando operarie wegens een plaveiselcelcarcinoom, een resectie voor een neuscarcinoom en cen laryngectomic wegens een larynxcarcinoom. 
Een patièrte werd geopereerd voor zowel een mammacarcinoom als een parotiscarcinoom, waarvoor een parotidectomie werd verricht gevolgd door halsklierdissectie en bestraling, waarna nog een deltoideopectorale lap noodzakelijk was wegens radiatienecrose.

Een andere pariënt ontwikkelde een maligne fibreus histiocytoom in de lies, wazvoor twee keer slijmerig materiaal uit de lies werd verwijderd, waarna een fistel resteerde die drie keer werd geëxcideerd, gevolgd door een omentumplastiek, die een recidief ook niet kon voorkomen.

\subsubsection{Reïnterventies wegens diverse aandoeningen in her interval}

Andere operaties die in het interval werden verricht waren: een maal een aortocoronaire bypass operatie en een maal een dubbelzijdige lumbale sympathectomie. Twee maal werd een laminectomie verricht wegens hernia nuclei pulposi.

Er werd een heupfractuur operatief behandeld en er werd een spongiosaplastiek verricht van de lumbale wervelkolom, waarvan de indicatie nier was te achrerhalen. Samenvattend waren er 109 re-operaties wegens septische complicaties bij 65 patiënten, $(42.2 \%) 58$ vasculaire re-operaties bij 31 patiënten, $(20.1 \%)$ en 76 andere re-operaties. Tabel 4.16 geeft een overzicht van de redenen voor alle late reïnterventies in het interval

Tabel 4.16. Overzicht van de redenen woor de late reïnterventies en de atantallen

\begin{tabular}{lrrr}
\hline reänterventies & aantal & patiènten & \% par \\
\hline seprische complicaties & 109 & 65 & 42.2 \\
bloedingscomplicaties & 4 & 4 & 2.6 \\
ischemische complicatics & 58 & 31 & 20.1 \\
amputaries & 8 & 6 & 3.9 \\
aand. wan de tr. digestivus & 24 & 19 & 12.3 \\
aand. van de tr.urogenitalis & 22 & 13 & 8.4 \\
maligniteiren & 12 & 5 & 3.2 \\
diversen & 6 & 6 & 3.9 \\
& & & $52^{*}$ \\
rotal & 243 & & 59.7 \\
\hline
\end{tabular}

* sommige partiennen hadden meendere complicaties 


\subsubsection{DE DUUR WAN HET INTERVAL}

Tabel 4.17 toont de relacie russen de duar van hec interval en de aantallen optredende infecties per periode. De kortste periode russen de primaire operatie en de behandeling van de infectie was 8 dagen. De langste periode bedroeg meer dan 18 jaar De gemiddelde duur van het incerval was 3.71 jaar en de mediane duur was 1.95 jaar.

Tabel 4.17. Frequenticverdeling wan her cijdstip van manifestarie van de infectie

\begin{tabular}{|c|c|c|c|}
\hline periode & 的 & $\%$ & cumulatief $\%$ \\
\hline <30dagen & 23 & 14.9 & 14.9 \\
\hline cussen 1 en 3 mond & 26 & 16.9 & 31.8 \\
\hline russen $3 \mathrm{~cm} 4 \mathrm{mod}$ & 4 & 2.6 & 34.4 \\
\hline mosen $4 \mathrm{en} 6 \mathrm{mnd}$ & 5 & 3.2 & 37.7 \\
\hline tussen 6 en 12 mond & 7 & 4.5 & 42.2 \\
\hline$>12$ maand & 89 & 57.8 & 100.0 \\
\hline Gotal & 15,4 & 100.0 & \\
\hline
\end{tabular}

In de literatur word op basis van incidentie, klinische presentatie of het oorakelijke micro-organisme onderscheid gemalkt tussen vroege en late infecties. (zie 2.5.1) In de meer recente literatuur wordr een grens gelegd bij 30 dagen $^{10}$ of bij 3.5 maanden ${ }^{131}$ Een onderverdeling op basis van het tijdsrip van manifestatie vò̀r of na 4 maanden wordt gegeven in tabel 4.18. Rum eenderde van de infecries (37.7\%) blijkt zich binnen de eerste 4 maanden te manifesteren en $62.3 \%$ daarna. Een AEF bleek significant later op te treden dan de PGI. $(\mathrm{p}<0.01)$

Tabel 4.18. Indelling van de infecties op basis van het rijdsrip wan presentatie

\begin{tabular}{|c|c|c|c|c|c|c|}
\hline rijdsrip & PGI & $\%$ & $\mathrm{AEF}$ & $\%$ & toraal & $\%$ \\
\hline vroeg (< 4 nind) & 48 & 31.2 & 10 & 6.5 & 58 & 37.7 \\
\hline fant ( $\times 4$ mnd $)$ & 44 & 6.5 & 52 & 33.8 & 96 & 62.3 \\
\hline rocall & 92 & 59.7 & 62 & 40.3 & 154 & 100 \\
\hline
\end{tabular}




\subsubsection{KLINISCHE PRESENTATIE}

Bij opname in het ziekenhuis, tijdens welke de diagnose werd gesteld of de behandeling van de infectie heeft plaatsgevonden, waren cen drietal hoofdcategorieèn van presentatie van de infectie te onderscheiden. (zie hig 1)

De eerste categorie werd gevormd door pariënten met afwijkingen in de lies die al na een eerste fysisch-diagnostisch onderzoek leidden tot het vermoeden, of de bevestiging van een infectie van de vaatprothese: een naadaneurysma, een abces, een fistel of een bloeding gelokaliseerd in de lies.

De tweede categorie bestond uit patiënten met presentatie met een bloeding uit de rractus digestivus of de tractus urogenitalis.

De derde categorie bestond uit patiënten met a-specifieke klachten ('malaise') en symptomen en verschijnselen die in het dossier soms slecht omschreven waren. Sperifieke klinische symptomatologie in de lies, $n=51$. Er waren in total 60 patiënten die één van de genoemde afwijkingen (een aneurysma spurium, een abces, een fistel of een bloeding) in de lies hadden.

Niet alle patiënten met een van deze afwijkingen in de lies presenteerden zich ook hiermee. Bij 51 patiënten stond de afwijking in de lies zodanig op de voorgrond dat op grond van die afwijking de infectie van de prothese vermoed of bevestigd werd (tabel 4.19). Van de 9 andere patiënten werden er 5 in eerste instantie opgenomen met een bloeding uit de tractus digestivus en 4 met aspecifieke klachten. Er

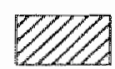

Malaise

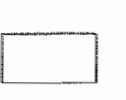

Gl
bloeding

\section{Lies}

symptomen

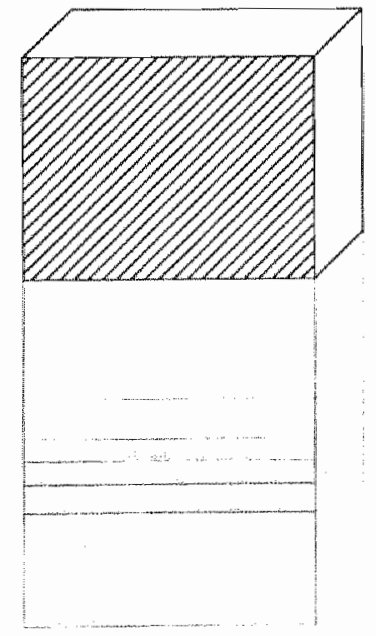

Gl blooding

Gl bloeding tiossymptamen Blooding

Vals aneurysma

Sinus

Abces

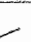

$40 \%$ llies symptomen

Figuur 1. Klinische presentatie van de prothese-infectic 
waren 3 patienten met cen aorrobi-liacale prothese, warbij de infectie zich in de lies maniffesteerde. Zij hadden na de primaire operatie een réoperatie ondergaan waarbij de lies werd geopend. Dertig patienten kwamen mer de liesafwijking naar de chirurgische afdeling, war zij de primaire operatic ondergingen. Achtien patienten werden door een andere chirurgische afdeling verwezen voor beluandeling. Een patiènt werd opgenomen via een urologische afdeling en één via een afdeling voor inwendige ziekten. Bij ceri patient werd de gang wan zaken niet duidelijk.

Tlabel 4.19. De werschinnselen in de lies die leidden tor vermoeden van een infectie

\begin{tabular}{lcc}
\hline Whoofdymptoom & $\mathrm{n}$ & $\%$ \\
\hline abces of nier genezen wond in de lies & 31 & 61.0 \\
maadineurysma in de lies & 6 & 13.7 \\
sinus in de lies & 9 & 17.6 \\
bloeding in de lies & 5 & 7.7 \\
& & \\
roral & 51 & 100.0 \\
\hline
\end{tabular}

Bloeding uit de tractus digestivus, $n=43$. Drieènveerig pariënten (27.9\%) presenteerden zich met een bloeding uir de tractus digestivus (tabel 4.20 ). Her ging in alle gevallen om een acure bloeding. Drieẻndertig patiënten hadden hematemesis en/ of melena en 9 partienten hadden massaal rood bloedverlies per anum. De beide anderen bloedden wit een darmfiscel en een nefrostoma. Drie patienten waren reeds min of meer bekend met chronisch bloedverlies uit de rractus digestivus.

Eenentwintig patiënten (48.8\%) presenteerden zich rechtstreeks bij de chirurgische afdeling waar ook de primaire operatie had plaatsgevonden, 9 patienten (20.9\%) werden verwezen via een andere chirurgische afdeling en 12 pariënten $(27.9 \%)$ werden opgenomen via een afdeling woor inwendige ziekten. Een patiënt (2.3\%) met en bloeding uit cen urostoma kwam via de afdeling urologie bij de vatchirurg terecht.

Tabel 4.20. Bloeding uir de mackus digestivus

\begin{tabular}{|c|c|c|}
\hline and wan de bloeding & $n$ & $\%$ \\
\hline hoog. acuut & 29 & 65.1 \\
\hline hoog, chromisch en actut & 3 & 7.0 \\
\hline lange acuir & 9 & 23.3 \\
\hline uit dundarmfistel & 1 & 2.3 \\
\hline uit nefrostoma & 1 & 2.3 \\
\hline rotal & 43 & 100.0 \\
\hline
\end{tabular}


Aspecifieke klachten en symptomen, $n=60$. Er waren 60 patiënten $(39.0 \%)$ zonder bloeding uit de tractus digestivus of afwijkingen in de lies (rabel 4.21). Van deze categorie patiënten (49.2\%) presenteerde er zich $29(49.2 \%)$ rechtstreeks op de chirurgische afdeling waar ook de primaire operarie had plaatsgevonden.

Dertien (22\%) patiënten werden opgenomen via een andere chirurgische afdeling en 17 pariënten $(28.8 \%)$ via andere specialismen

De klachten waren in her medisch dossier vaak onduidelijk omschreven, mede ten gevolge van her feit dat, in eerste instantie de diagnose meestal niet werd overwogen.

"rabel 4,21. Overzicht van de aspecifieke klachten en symptomen

\begin{tabular}{lcc}
\hline aard van de klachren & $\mathrm{n}$ & $\%$ \\
\hline koorts mer koude rillingen & 24 & 40.0 \\
buikklachren met "défense musculaire" & 14 & 23.3 \\
buikklachren met koorts en malaise & 10 & 16.7 \\
koorts en malaise zonder buikklachten & 6 & 10.0 \\
vage klachren zonder septische verschijnselen & 6 & 10.0 \\
& & \\
total & 60 & 100.0 \\
\hline
\end{tabular}

Her merendeel van de pariënten uir deze groep had koorts als teken wan sepsis en/of buiktklathten. Zes parienten hadden geen of vrijwel geen septische werschijnselen. Bij vier wan hen werd de infectie bij toeval gevonden; twee keer bij operatie wegens afsluiting wan een prothesebeen, een keer per-operatief bij een geplande perifere bypass-operatie, en eemmall bij een patièn die werd geopereerd wegens een coloncarcinoom. Van de anderen had cón alleen rugkdachten en én had een recidiverend retroperitonecal hematoom.

Klinische presentaric met aspecifieke symptomatologie bleek bij vroege infecties significant meer voor te komen $(p<0.01)$. Presentatie met liesproblemen of blocding uit de tractus digestivus kwam significant meer voor bij de laat optredende infecties, terwijl presentatie met een naadaneurysma of een sinus uitsluitend bij de late infecties voorkomen.

\subsubsection{OVERIGE SYMPTOMATOLOGIE:}

Naast de bovengenoemde drie hoofdcaregoriën van verschijnselen bij de eerste klinische presentatie waren er verdeeld over alle patiènten andere, hieronder opgesomde merendeels aspecifieke, bevindingen die cen bijdrage leverden aan het tor stand komen van de diagnose. 


\subsubsection{Malaiseklachren}

Over dexe klacht bij de presentatie werden gegevens vermeld in de dossiers van 118 patiënten $(76.6 \%)$. Van deze 118 patiënten hadden er $84(71.2 \%)$ klachten over algemene malaise, moeheid en/of een gevoel van ziek zijn.

\subsubsection{Lichaamstemperaruur}

De lichaamstemperaruur bij presentatie is bekend van 112 patiènten $(72.7 \%)$. Van deze 112 pariënten hadden er $74(66.1 \%)$ koorts (lichaamstemperatuur > $\left.37.5^{\circ} \mathrm{C}\right)$.

\subsubsection{Sepsis}

Gegevens over her voorkomen van sepsis, gedefinieerd als koorts met koude rillingen of koorts met een positieve bloedkweek bij presentatie waren vastgelegd bij 149 patiënten (96.8\%). Bij 57 van deze 149 patiënten (38.3\%) werd een sepsis vastgesteld.

\subsubsection{Septische embolie}

Gegevens over het optreden van dit verschijnsel waren bekend bij 148 patiënten (96.1\%). Een seprische embolie werd gezien bij 9 patiënten (5.8\%). Vier patiënten hadden een arthritis van de knie (3) of van de enkel (1) en 5 pariënten hadden een embolisch abces in het been.

\subsubsection{Bezinkingssnelheid van de erythrocyten (BSE)}

De warden hiervan bij opname waren bekend bij 82 patiënten (53.2\%) en worden weergegeven in tabel 4.22 .

Tabel 4.22. Bezinkingssnelheid van de erythrocyten bij opname.

\begin{tabular}{lrl} 
bezinking & $\mathrm{n}$ & $\%$ \\
\hline$<20 \mathrm{~mm} /$ uur & 9 & 11.0 \\
$20-50 \mathrm{~mm} /$ uut & 20 & 24.4 \\
$50-100 \mathrm{~mm} /$ uur & 32 & 39.0 \\
$>100 \mathrm{~mm} /$ unt & 21 & 25.6 \\
totaal & 82 & 100.0 \\
\hline
\end{tabular}




\subsubsection{Leucocyten}

Her leucocytengetal bij opname werd teruggevonden in de dossiers van 104 patiënten $(67.5 \%)$ en wordr weergegeven in tabel 4.23 .

Tabel 4.23. Aantal leucocyten bij opname

\begin{tabular}{lrl}
\hline aantal leucocyten & $\mathrm{n}$ & $\%$ \\
\hline$<10 \times 106 / \mathrm{mm} 3$ & 34 & 32.7 \\
$10-20 \times 106 / \mathrm{mm} 3$ & 57 & 54.8 \\
$20-30 \times 106 / \mathrm{mm} 3$ & 12 & 11.5 \\
$>30 \times 106 / \mathrm{mm} 3$ & 1 & 1.0 \\
rotaal & 104 & 100.0 \\
\hline
\end{tabular}

De verdeling van de verschillende aspeciffeke bevindingen over de drie hoofdcategorieën van initiële presenterende symptomatologie is weergegeven in tabel 4.24 . Tussen haakjes staat het percentage van voorkomen per categorie (waarvan de gegevens van het betreffende onderdeel bekend zijn?

Tabel 4.24. Overzicht a-specifieke begeleidende bevindingen per patiëntencategorie

\begin{tabular}{|c|c|c|c|}
\hline \multirow[t]{2}{*}{ caregorice } & lies & bloeding & a specifiek \\
\hline & $n \quad(\% 0)$ & n $(\%)$ & $n \quad(\%)$ \\
\hline \multicolumn{4}{|l|}{ leucocyten } \\
\hline$<10 \times 106 / \mathrm{mm} 3$ & $1.4(42.4)$ & $10(38.5)$ & $10(22.2)$ \\
\hline $10-20 \times 106 / \mathrm{mm}^{3}$ & $15(45.5)$ & $14(53.8)$ & $28(62.2)$ \\
\hline $20-30 \times 106 / \mathrm{mm}^{3}$ & $3(9.1)$ & $2(7.7)$ & $7(15.6)$ \\
\hline$>30 \times 106 / \mathrm{mm} 3$ & $1(3.0)$ & - & \\
\hline \multicolumn{4}{|l|}{$\mathrm{BSE}$} \\
\hline$<20 \mathrm{~mm} / \mathrm{h}$ & $3(11.5)$ & $3(15.0)$ & $3(8.4)$ \\
\hline $20-50 \mathrm{~mm} / \mathrm{h}$ & $6(23.1)$ & $9(45.0)$ & $5(13,9)$ \\
\hline $50-100 \mathrm{~mm} / \mathrm{h}$ & $12(46.2)$ & $8(40.0)$ & $12(33.3)$ \\
\hline$>100 \mathrm{~mm} / \mathrm{h}$ & $5(19.2)$ & - & $16(44,4)$ \\
\hline \multicolumn{4}{|l|}{ symptomen } \\
\hline malaiseklachten & $20(38.5)$ & $23(46.9)$ & $41(32.5)$ \\
\hline temperatuurverhoging & $21(40.4)$ & $12(24.5)$ & $41(32.5)$ \\
\hline septische embolie & $1(1.9)$ & $4 \quad(8.2)$ & $7(5.6)$ \\
\hline sepsis & $10(19.2)$ & $10(20.4)$ & $37(29.4)$ \\
\hline
\end{tabular}


Omdar er veel onduidelijkheid bestaat over de rol van naadaneurysma's bij infecrics van (abdominale) vaatprothesen ${ }^{284}$ worden de gegevens daarower hier apart samengevar.

In de hele serie zijn er in total 48 patiënten (38.3\%) met 66 naadaneurysma's. Reïnterventies wegens naadaneurysma in het interval, voorafgaande aan de opname waarin de diagnose werd gesteld, werden 34 maal verricht bij $26(16.9 \%)$ patiënren. (zie 4.2.3) Bij opname voor behandeling van de infectie werden in totaal 32 valse aneurysma's gevonden bij 30 pariënten.(19.5\%) Acht pariënten hadden op her moment dat zij zich met een geïnfecteerde prothese presenteerden én een vals aneurysma bleken te hebben, minstens één voorafgaande operatie wegens wals aneurysma ondergaan. Twee patiënten hadden een vals aneurysma zowel op de proximale als op de distale naad.

De valse aneurysma's waren bij presentarie 19 keer in de lies en 13 maal abdominaal gelokaliseerd.

Dat had tevens een naadaneurysma proximaal.

Van de 51 patiënten die zich mer symptomen in de lies als manifestatie van de prothese infectie presenteerden waren er 10 met een vals aneurysma, waarvan er 6 die zich met dat aneurysma presenteerden.

Van de 43 patiënten die zich presenteerden met een bloeding uit de tractus digestivus hadden er 9 een vals aneurysma, warvan 5 proximaal gelokaliseerd en 4 distaal.

Van de 60 patiënten met aspecifreke klachten hadden 11 patiènten 12 aneurysma's waarvan 7 proximaal en 5 distal.

De tijd tussen de primaire operatie en de behandeling van (het eerste) valse aneurysma was gemiddeld 4.2 jaar met een maximum van 15.5 jaar en een minimum van 85 dagen. De helft van de valse aneurysma's ontstond binnen 2.2 jaar. De rijd tussen de behandeling van het eerste valse aneurysma in het interval en de behandeling van de protheseinfectie was gemiddeld 1.7 jaar (mediaan 1.1 jaar) met een minimum van 15 dagen en een maximum van 5.7 jaar.

Her tijdsbestek tussen de laatste behandeling van een vals aneurysma en de behandeling van de infectie bedroeg gemiddeld 1.3 jar ( 15 dagen- 5.5 jaar) en mediaan 1..l jaar.

\subsubsection{DIAGNOSTIK}

In deze sectie wordt cen overzicht gegeven van de verschillende diagnostische technieken die bij de totale groep patiënten werden ingezer. Voor iedere techniek worden de belangrijkste bevindingen en hun bijdrage aan het tot stand komen van de diagnose besproken. In totaal werd $20.8 \%$ van de pariënten in onze serie zonder 
aanvullende diagnosicek behandeld en werd bij $79.2 \%$ één of meer van de genoemde diagnostische hulpmiddelen ingezet.

\subsubsection{Echografie}

Echografie (zie tabel 4.25) werd verricht bij 64 pariënren ( $41.6 \%$ ) Driemaal leverde her onderzoek geen bruikbaar resultaat op en drieëntwintig maal waren er geen afwijkingen te vinden. Duidelijke afwijkingen werden gevonden bij 38 patiënten, dus in meer dan de helft van alle onderzoeken. Afwijkingen die bewijzend waren voor de diagnose werden zestien maal (25\%) gevonden, te weten: 14 keer vocht of pus en rweemaal een infiltraat rond de prothese. Bevindingen die een aanwijzing kunnen zijn voor het bestaan van een infecrie werd negenmal aangetroffen in de vorm van zeven in tra-abdominale abcessen en tweemaal vrij vocht intra-abdominaal. Minder specifieke aanwijzingen voor infectie waren 3 retroperitoneale hematomen, eenmaal een pancreasabces, eenmaal de darm gevuld met bloed, 7 (naad)aneurysma's en één hydronefrose.

Tabel 4.25. Bevindingen bij echografie $n=644$

\begin{tabular}{lcc}
\hline bevindingen & $n$ & 0 \\
\hline geen afwijkingen & 26 & 40.6 \\
voch of pus rond prothese & 14 & 21.9 \\
infiluraat rond prothese & 2 & 3.1 \\
intra-abdominaal ahoes & 7 & 10.9 \\
intra-abdominat vrij wocht & 2 & 3.1 \\
retroperironeal hematoom & 3 & 4.7 \\
aneurysna & 7 & 10.9 \\
pancreasabces & 1 & 1.6 \\
darm gevuld met bloed & 1 & 1.6 \\
bydronefrose & 1 & 1.6 \\
totaal & & 100.0 \\
\hline
\end{tabular}

\subsubsection{Computertomografie}

Computertomografie (zie tabel 4.26) werd verricht bij 80 patiënten $(52.9 \%$ ). Bij 8 patiënten werden geen afwijkingen gevonden. Duidelijke afwijkingen daarentegen werden gevonden bij 72 patiënten, dus bij $90 \%$ van alle onderzoeken. Bevindingen die bewijzend waren woor het bestaan van een infectic van de vaatprothese werden 52 maal $(65.0 \%)$ gediagnostiseerd: vocht of puscollectie $(21)$, vochtcollectie met gasbellerjes (22), een infiltraat rondom de prothese (8) en contrast rondom 
de prothese (1). Bij 8 patiënten werd een intra-abdominaal abces gevonden en bij 3 een psoasabces. Daarnaast waren er 3 patiënten met één aneurysma en 2 patiënten met meerdere aneurysma's op de prothesenaden. Bijécén pariënt was lekkage van de ureter zichtbaar. Er waren 2 pariënten met vrij vocht intra-abdominaal en één patiènt met een retro-peritoneaal hematoom.

Tabel 4.26. Bevindingen bij computertomografie $n=80$

\begin{tabular}{|c|c|c|}
\hline bevind ingen & $n$ & $\%$ \\
\hline geen afwijkingen & 8 & 10.0 \\
\hline vocht, pus of gas rond de prothese & 44 & 55.0 \\
\hline infiltraat rond de prothese & 8 & 10.0 \\
\hline abces intra of retroperitoneal & 11 & 13.8 \\
\hline vrij voche intra-abdominaal & 2 & 2.5 \\
\hline retroperitoneal hematoom & 1 & 1.3 \\
\hline Dataneurysma's & 5 & 6.3 \\
\hline ureterlekkage & 1 & 1.3 \\
\hline totaal & 80 & 100.0 \\
\hline
\end{tabular}

\subsubsection{Sinografie}

Sinografte werd verricht bij 18 patiënten $(11.7 \%)$. Eenmaal was het resultaat niet te achterhalen. Bij alle andere onderzoeken werd ten minste één prothesepoot ongeven door contrast zichtbaar. Bij vijf patiënten was het contrast te volgen tot aan het centrale prothesedeel of was er overloop van contrast zichtbaar naar de contralaterale zijde. Bij een patiënt werd een abces zichtbaar en bij een andere met een aorto-entero-vesicale fistel werd zowel de prothese als de blaas èn het colon afgebeeld.

\subsubsection{Isotopenscintigrafie}

Geanalyseerd werden de uitslagen wan scintigrafie met Indium ${ }^{1 / 1}$ gelabelde leucocyten wan de patiënt. Sporadisch werden ook Gallium scans verricht. De uitslagen hiervan zijn niet verwerkt. In totaal werd bij 22 patiënten (14.3\%) indium ${ }^{11} 1_{\text {-sci- }}$ ntigrafie verricht. Zeven maal was de uitslag negatief en vifftienmal ( $68 \%$ ) werd er een abnormale ophoping van gelabelde leucocyten gevonden, waarvan 8 unilateraal, 5 centraal en 2 zowel centraal als bilateraal gelokaliseerd waren. 


\subsubsection{Magnetische resonantie onderzock}

Onderzoek met behulp van magnetische resonantie werd in de onderzochte paw tiëntengroep in totaal maar drie keer verricht. Luchtbellen rondom de prothese werden in twee gevallen waargenomen. Bij de derde pariënt waren er geen afwijkingen zichrbaar.

\subsubsection{Echo geleide aspiratie}

Van de mogelijkheid om met behulp van een echogeleide punctie pus of vocht te verkrijgen dat zich rondom de prothese bevindt, werd bij 10 patiënten $(6.5 \%)$ gebruik gemaakt. Zeven kweken waren positief (70\%) en twee maal bleef de kweek van het verkregen materiaal steriel. Van één kweek was de uitslag niet te achterhalen.

\subsubsection{Computertomografisch geleide aspiratie}

Deze diagnostische mogelijkheid werd bij zeventien patiënten (11.0\%) benut. Het verkregen materiaal was zeven keer steriel en negen keer werden pathogene micro-organismen gekweekt (53\%), terwijl ook hier één uitslag onvindbaar bleef.

\subsubsection{Gastroduodenoscopie}

Gastroscopie (zie tabel 4.27) werd bij 38 patiënten (22.7\%) verricht. Bij 17 patiënten werden geen afwijkingen waargenomen en wan 3 onderzoeken waren de bevindingen niet meer te achterhalen. Bij 15 gastroscopiën bleek de waargenomen afwijking vijfmaal bewijzend voor een prothese-infectic en achtmaal vormde de gevonden afwijking een bijdrage tot de diagnose. Tweernal werd de omschrijving

Tabel 4.27. Bevindingen bij gastroscopie

\begin{tabular}{lcc}
\hline bevinding & $\mathrm{m}$ & \% van alle gastroscopiäun \\
\hline geen afwijkingen & 17 & 48.6 \\
aorto-enterale fiscel & 2 & 5.7 \\
prothese zichtbaar & 5 & 14.3 \\
bloedig geimbiberd duodenum & 1 & 2.9 \\
crosie duodenum & 1 & 2.9 \\
duodenum vol bloed & 4 & 11.4 \\
krater in duodentum & 2 & 5.7 \\
gastritis & 1 & 2.9 \\
ulcus duodeni & 2 & 5.7 \\
& & 100.0 \\
\hline
\end{tabular}


'aorto-enterale fistel' gevonden zonder nadere uitleg op grond waarvan deze conclusie werd getrokken. Driemaal werd een andere, niet rechtstreeks an een infectie gerelateerde, afwijking gevonden: tweemaal een ulcus duodeni en eenmaal gasrrieis.

\subsubsection{Colonoscopie}

Colonoscopie (zie tabel 4.28) werd zestienmaal verricht (10.4\%). In 8 gevallen werd geen afwijking gevonden en van 1 onderzoek was het resultaat niet meer te achterhalen. Eenmaal werd de prothese in het colon lumen zichrbaar hetgeen bewijzend is voor een prothese-infekt, terwijl eenmaal een andere afwijking (poliep) werd gevonden. In de zes andere gevallen werd een afwijking gevonden die mogeliik een bijdrage tot de diagnose zou kunnen vormen.

Tabel 4,28. Afwijkingen bij colonoscopie

\begin{tabular}{lcc}
\hline bevinding & n & \% van alle colonoscopiern \\
\hline geen afwijkingen & 8 & 53.3 \\
prothese zichrbar & 1 & 6.7 \\
ischemische colitis & 2 & 13.3 \\
melena & 1 & 6.7 \\
wree ulcera sigmoìd & 1 & 6.7 \\
sigmoïd vol nood bloed & 1 & 6.7 \\
poliep & 1 & 6.7 \\
& & \\
tocaal & 15 & 100.0 \\
\hline
\end{tabular}

\subsubsection{Angiografie}

Arteriografisch onderzoek (zie tabel 4.29) werd bij 65 pariënten verricht (42.2\%). Zeventmaal waren de resultraten niet meer te achterhalen en bij 38 patiënten werden geen afwijkingen gevonden (tabel 4 l). Bij 11 patiënten toonde angiografie een ancurysma spurium aan en zevenmaal werd een afsluiting van cen of beide prothesebenen gevonden. Eenmaal werden de nierarteriën niet zichtbaar. Bij één patiënt werd de aorto-enterale fistel direct gevisualiseerd.

Samenvatrend blijkt dat computertomografie bij de instrumentele dagnostiek van de infectie van de abdominale vaatprothese een centrale plaats inneemt, maar niet het hoogste scoort bij het bewijs van de prorhese-infectie (figuur 2). 
Tabel 4.29. Bewindingen bij angiografie

\begin{tabular}{lrc}
\hline bevindingen & $\mathrm{n}$ & \% wan alle angiografeèn \\
\hline geen uirslag & 7 & 10.8 \\
geen afwijkingen & 38 & 58.5 \\
occlusie prothesebe(e) nen & 7 & 10.8 \\
aneurysma spurium & 11 & 16.9 \\
nierarteriën niet afgebeeld & 1 & 1.5 \\
aneurysma spurium taorto-enterate fistel & 1 & 1.5 \\
total & & \\
\hline
\end{tabular}

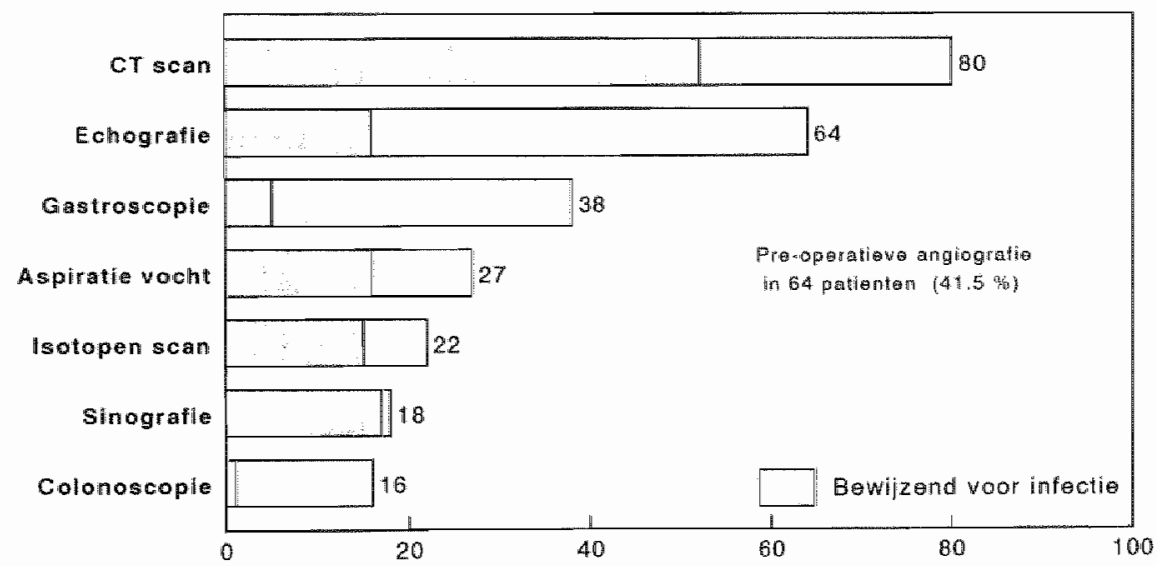

Figutur 2. Overzich van de diagnosick van de prothese-infectie

\subsubsection{MICROBIOLOGHE}

Een wondkweek van de abdominale of lieswond of fistel bij opname kon van 48 patienten worden achterhaald, warbij in 42 gevallen $(87.5 \%)$ een parhogeen micro-organisme kon worden gelwwekt.(tabel 4.30) In 66.7\% van de kweken werden gram positieve coccen gevonden. 
Tabel 4.30. Microbiologisch onderzock wan de wonden en/of fistel bij de opname woor behandeling varn de infectie van de protherse.

\begin{tabular}{|c|c|c|}
\hline micro-organisme & $n$ & $\%$ \\
\hline So ataretis & 16 & 33.3 \\
\hline Sepidemidis & 1 & 2.1 \\
\hline andere gram positieve coccen & 3 & 6.3 \\
\hline gram negatieve coccen & 9 & 18.8 \\
\hline gram positieve staven & 3 & 6.3 \\
\hline anaièroben & 1 & 2.1 \\
\hline gram positieven + gram negarieven & 3 & 6.3 \\
\hline S. awews tandere micro-organimen & 2 & 42 \\
\hline 5. epudernidis + anaèroben & 1 & 2.1 \\
\hline S. epudemidis + andere micro-organimen & 2 & 4.2 \\
\hline $\operatorname{res}$ & 1 & 2.1 \\
\hline geen groei & 6 & 12.5 \\
\hline total & 48 & 100.0 \\
\hline
\end{tabular}

De 72 afgenomen bloedkweken (zie tabel 4.31) Jeverden in 41 gevallen een positief kweekresultat op. In de 31 andere bloed monsters konden geen pathogene micro-organismen worden angetoond. Staphylococcen waren in dertig procent van de gevallen verantwoordelijk voor de sepsis.

T'abel 4.31. Microbiologisch onderzock van her bloed bij de opname voor behandeling van de infecrie van de prothese

\begin{tabular}{|c|c|c|}
\hline micro-organisme & $\mathrm{n}$ & $\%$ \\
\hline S. aurotes & 10 & 13.9 \\
\hline Sepudermidis & 2 & 2.8 \\
\hline andere gram posinieven & 4 & 5.6 \\
\hline gram negatieve coccen & 16 & 22.2 \\
\hline gram positicue staven & 2 & 2.8 \\
\hline anaéroben & 2 & 2.8 \\
\hline hingi & $\mathbb{1}$ & 1.4 \\
\hline gram positicven en gram negatieven & 2 & 2.8 \\
\hline anateroben met gram positieven & 2 & 2.8 \\
\hline geen groei & 31 & 43.1 \\
\hline rotaal & 72 & 100.0 \\
\hline
\end{tabular}


Het resultaat van microbiologisch onderzoek van her materiaal dar werd verkregen bij de echo- en/of CT-geleide punctie bij opname voor de behandeling van de infectie van de prothese zoals gevonden bij 25 van de 27 patiënten wordi weergegeven in tabel 4.32 .

Tabel 4.32. Microbiologisch onderzoek van her materiaal verkregen bij echo-geleide punktie

\begin{tabular}{lcc}
\hline micro-organisme & $\mathrm{n}$ & \% van alle echogeleide punkries \\
\hline S. aureus & 2 & 8 \\
S. epidermidis & 1 & 4 \\
gram negatieve coccen & 4 & 16 \\
gram positieve staven & 1 & 4 \\
gram positieven en gram negarieven & 5 & 20 \\
anaëroben & 1 & 4 \\
anaëroben en gram positieven & 1 & 4 \\
rest & 1 & 4 \\
geen groei & 9 & 36 \\
total & 25 & $100 \%$ \\
\hline
\end{tabular}

\subsection{DE BEHANDELING}

\subsubsection{INLEIDING}

\subsubsection{Tijdsduur tussen de diagnose en de behandeling van de infectie}

Het tijdstip waarop duidelijk werd dat er sprake was van een infectie van de abdominale vaatprothese werd in veel dossiers niet duidelijk aangegeven. Dit tijdstip is achteraf, bij benadering, vastgesteld door combineren en deduceren van de in het dossier aanwezige gegevens in het operatieverslag, ontslagbrieven, uitslagen van verschillende onderzoeken en decursus. De langste rijdsduur cussen her stellen van de diagnose en de behandeling bedraagt vijf jaar. De tijdsduur tussen het stellen van de diagnose en het tijdstip van de behandeling wordt voor de verschillende soorten behandeling weergegeven in tabel 4.33 . 
Tabel 4.33. De tijdsdurur masen het stellen wan de diagnose on de behandeling $(n=154)$ in dagen:

\begin{tabular}{lcccc}
\hline Uidsduur in dagen & minimum maximum & gemiddeld median \\
\hline catcgorie: & & & & \\
belegroep & 0 & 1788 & 72.5 & 3.5 \\
primair radicaal & 0 & 791 & 20.5 & 3.0 \\
secundait radical & 0 & 1788 & 365.4 & 19.0 \\
nicr-radical & 0 & 362 & 39.5 & 1.5 \\
\hline
\end{tabular}

\subsubsection{Urgentie}

Van de 154 patiënten werden er $58(37.9 \%)$ met spoed buiten het normale operarieprogramma geopereerd. Van één partënt is dit gegeven nier bekend.

\subsubsection{INDELING VAN DE INEECTIES}

Ten behoeve van een gedifferentieerde analyse van de behandelingsresultaten werden de infecties van de abdominale vatprothese op basis van de resultaten van de diagnostiek en de gegevens voorkomend wit de behandeling (zie 3.3.5.1) onderverdeeld in twee hoofdcategorièn: infecties rondom de prothese of perigraft infecties (PGI) en aorto-enterale fistels (AEF). Tabel 4.34 geefc een onderverdeling van de infecties gerubriceerd naar de indicatie voor de primaire operatie. Het optreden van infectie in de vorm wan PGI of AEF bleek niet signficant samen te hangen met her feit of de primaire operatie werd verricht wegens oblitererend of dilaterend vaatijiden.

Tabel 4.34. Indeling van de infecties en indicatie wan de primaire operatie

\begin{tabular}{|c|c|c|c|c|c|c|}
\hline & \multicolumn{2}{|c|}{ PGI } & \multicolumn{2}{|c|}{ AEF } & \multicolumn{2}{|c|}{ total } \\
\hline & n & $\%$ & $\mathrm{n}$ & $\%$ & $\mathrm{n}$ & $\%$ \\
\hline aneurysma & 60 & 39.5 & 31 & 20.4 & 91 & 59.9 \\
\hline obstrueresd watlijden & 32 & 21.1 & 29 & 19.1 & 61 & 40.1 \\
\hline rotal & 92 & 60.6 & $60^{*}$ & 39.5 & 152 & 100.0 \\
\hline
\end{tabular}

* bii 2 paremen ner AEF werd de indicatie voor de primaire operatie nier achterhaald 


\subsubsection{MNDELING VAN DE BEHANDELING}

De indeling van de uiteindelijke behandelingen wan de prothese-infectie naar radicall, secundair radical en nier-radicaal zoals deze is gedefurieerd onder 3.3 .4 .2 wordt weergegeven in tabel 4.35 .

Tabel 4.35. De behandeling van de beide typen infecte van de abdominale varprothese $n=154$

\begin{tabular}{|c|c|c|c|c|c|c|}
\hline \multirow[t]{2}{*}{ behandeling } & \multicolumn{2}{|c|}{ PGI } & \multicolumn{2}{|c|}{ AEF } & \multicolumn{2}{|c|}{ totaal } \\
\hline & $\mathrm{n}$ & $\%$ & $\mathrm{n}$ & $\%$ & n & 婙 \\
\hline primair radicaal & 57 & 37.0 & 36 & 23.4 & 93 & 60.4 \\
\hline secundair radicaal & 9 & 5.8 & 12 & 7.8 & 21 & 13.6 \\
\hline nier-radical & 20 & 13.0 & 12 & 7.8 & 32 & 20.8 \\
\hline geen & 6 & 3.9 & 2 & 1.3 & 8 & 5.2 \\
\hline rotaal & 92 & 59.7 & 62 & 40.3 & 154 & 100.0 \\
\hline
\end{tabular}

Radicale verwijdering van de prothese vond plaats bij 114 patiënten. Orieënnegentig paciènten ondergingen de radicale behandeling als eerste en enige chirurgische behandeling.

Driënvijftig patiënten werden in eerste instantie niet-radicaal behandeld. Bij 21 van deze 53 patiënten (39.6\%) leidde de niet-radicale behandeling nier tor her gewenste resultaat en moest na de aanvankelijke niet-radicale behandeling, worden overgegegaan tot (secundair) radicale behandeling. (zie 4.3.3)

De 21 pariënten waarbij de prothese secundair radicaal werd verwijderd werdien in eerste instantie behandeld zoals omschreven bij 'de niet-radicalc behandeling' van de prothese. Wegens onvoldoende resultaat wan deze niet-radicale behandeling moest later verdere behandeling volgen warbij de prothese alsnog werd werwijderd. Van de 21 patiènten, hadden er 9 een aorto-enterale fistel an 12 cen perigraft infecrie.

De tijdsduur tussen de eerste, niet-radicale behandeling, en de secundaire radicale behandeling warieerde van één dag tot negen jaar, met een gemiddelde van iets meer dan twee jaar, de mediane waarde lag bij 1.62 jaar.

De niet-radicale behandelingswomen die bij deze parienten werden rocgepast bestonden wít drainage (3) vervanging van een deel wan de prothese (9), resectie van cen ded wan de prothese (3), overhechter van de fistel (2) en dunnedarm resecrie (4), in 7 gevallen gecombineerd mer ecn. omentumplasciek.

Nader gespecificeerd als volgr: Bij 7 parienten werd (een deel van) de prothese vervangen: bij 2 pariënten werd een geheel nieuwe prothese ingebracht, bij bén pariënt werd én been van de prow 
these vervangen en bij 4 patienten werd her proximale deel van de prothese vervangen, dat daar. na bedekw werd door ex omentumplastiek. Bij 3 patiënten werd een (deel wan een) poot van de prothese werwijderd zonder terwanging. Bij 2 parienten werd alleen de duodenumfistel overbecht, een keer gecombineerd met een omentumplastick. Bij 3 patiënten werd in eerste instantie alleen drainage van een ontstekingsproces verriche. Tweemad was dir onder de aanwankelijke di-

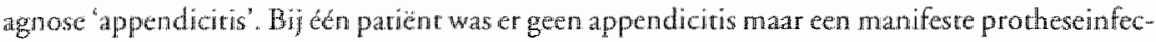
rie, die de wolgende dag werd behandeld. Bij de andere patient werd nier duidelijk of de appendix in een periprothetisch abces lag of dat her om een primair appendiculair abces ging. $\mathrm{Bij} 4$ patienten werd een darmresectie verrich: bij twee pariënten ging her uitsluitend om en aortoenterale erosie, walvoor een dunne darmuesectie met omenumplastiek werd verricht. Eén patient had een coloncarcinoon met doorgroei naar de prothese, waardoor deze bij signoidresecrie volgens Hartman bloot kwam te liggen. Bij de andere patiënt ging het om een geabcedecrde diverticulitis. Na de niet-radicale behandeling ontstond bij 3 parienten een recidief aorto-enteralle fistrel. De zes andere aorto-enterale fistels manifesteerden zich in tweede instantie als PGL. Drie pariènten die arnvankelijk cen PGI hadden kregen in tweede instantie een AEF. Bij 25 patienten werd de prothese gedeeltelijk verwijderd. De redenen voor deze keuze was achteraf niet volledig meer te achterhalen.

Bij cén patiént werd her centrale deel van de prothese verwijderd en in 24 gevallen werd (cen deel van) een wan beide prothesebenen verwijderd.

Bij 7 parienten, werd in het geheel niets wan de prothese verwijderd omdat bewust gekozen werd voor behandeling zonder de protheseverwijdering.

In een geval was dar ondat men duidelijk de voorkeur gaf aan locale behandeling en in 5 gevallen werd op grond van leeftijd en conditie gekozen voor behandeling zonder protheseverwijdering. Bij ćén pariènt was de reden niet te achterhalen.

De beide nietr-radicaal behandelde patiënten met AEF werden behandeld door middel wan slturen wan de fistel, waarbij cen keer de fistel werd afgedekr door het omentum majus en een spoelsystecm werd achtergelaten. Van de 5 niet-radical behandelde patiënten met een PGI werden er 3 behandeld door middel wan inbrengen van cen spoelsystem: bij één patient werd de losliggende proximale anastomose opnieuw gehecht en bij de ander werd cen distale anastomose opnienw gehechr en bedekt met cen sartoriusplastick.

Ache partitnten werden uiet behandeld. Bif 7 parienten werd her niet zinwol geache om de infecrie te behandelen. De radenen om bij deze pariènten te abstineren warens seprische en/of verbloodingsshock (2), abdominale sepsis (2), leetrijd en conditic (1), tevens anawezig maligne histrocy toom rondom de prorhese in de lies (1), en cen abces tor op de prothese bij cen patienr die ecrder ecn heupexarticularie en een bovenbeensamputatic aan de contralaterale kant onderging (1). Bij I parient werd de operatio beëindigd roen bleck dat de geplande protheseverwijdering om rechnische reden nier mogelijk was omdar de infra-renale aortastomp re kort zou worden om ce sluiren.

De gemiddelde duur van het interval verschilde niet statistisch significant voor radicale en niet-radicale behandeling. 


\subsection{BEVINDINGEN BU OPERATIE}

\subsubsection{Ingroei van de prothese}

Mededelingen hierover door de operateur waren te vinden in 116 operatieverslagen. $(74.7 \%) \mathrm{Zij}$ worden weergegewen in tabel 4.36 .

Tabel 4.36. Bevindingen tijdens operatie naar type infectie

\begin{tabular}{|c|c|c|c|c|c|c|}
\hline \multirow[t]{2}{*}{ bewinding } & \multicolumn{2}{|c|}{ PGI } & \multicolumn{2}{|c|}{$A \mathrm{AEF}$} & \multicolumn{2}{|c|}{ totial } \\
\hline & $\mathbb{1}$ & $\%$ & $n$ & $\%$ & $\mathrm{n}$ & $\%$ \\
\hline pus rond prothese & 56 & 48.3 & 20 & 17.2 & 76 & 66.5 \\
\hline wocht rond prothese & 9 & 7.8 & 3 & 2.6 & 12 & 10.3 \\
\hline losliggende prothese & 15 & 12.9 & 10 & 8.6 & 25 & 21.6 \\
\hline goed ingegroeide prothese & - & - & 3 & 2.6 & 3 & 2.6 \\
\hline totaal & 80 & 69.0 & 36 & 31.0 & 116 & 100.0 \\
\hline
\end{tabular}

\subsubsection{Lokalisatie van de aorto-enterale fistel}

De organen waarnaar de fisteling vanuit de prothese had plaars gevonden bij de patiënten met een AEF zijn opgesomd in tabel 4.37.

Tabel 4.37. Lokkalisatie van de aorto-enterale fistels onderverdeeld naar rype behandeling

\begin{tabular}{|c|c|c|c|c|c|c|}
\hline \multirow{2}{*}{$\begin{array}{l}\text { behandeling } \\
\text { lokalisatie fistel }\end{array}$} & \multicolumn{2}{|c|}{ radicaal } & \multicolumn{2}{|c|}{ niet-radical } & \multicolumn{2}{|c|}{ totaal } \\
\hline & n & $\%$ & $n$ & $\%$ & $n$ & $\%$ \\
\hline duodenum & 34 & 54.9 & 4 & 6.4 & 38 & 61.3 \\
\hline jejunum & 10 & 16.2 & 5 & 8.0 & 15 & 24.2 \\
\hline sigmoid & 2 & 3.2 & 4 & 6.4 & 6 & 9.7 \\
\hline coecum & - & - & 1 & 1.6 & $\mathbb{1}$ & 1.6 \\
\hline ureter & 1 & 1.6 & - & - & 1 & 1.6 \\
\hline jejunum/ureter & 1 & 1.6 & - & - & 1 & 1.6 \\
\hline rotaal & 48 & 77.6 & 14 & 22.4 & 62 & 100.0 \\
\hline
\end{tabular}


Bij de 114 patienten warbij dle prothese radicaal werd verwijderd moest de aorta worden gesloten. Bij 20 pariënten was bij de primaire operatie, een proximale end to side anastomose aangelegd en bij 94 pariënten bestond een proximale end to end anastomose. Bij de patiënten met een proximale end to side anastomose werd de aorta 8 keer in zijn geheel onderbonden of dichtgehecht. Elfmaal werd de aortotomie primair gesloten, en eenmaal werd in de bestaande aortotomie een nieuwe prothese ingehecht. Van de 94 patiënten met een proximale end to end anastomose, werd bij één patiënt een nieuwe prothese ingehecht. Bij alle andere patiënten werd de aorta eindstandig gesloten. Bij 6 patiënten leidde her sluiten van de aortastomp per-operatief tot problemen:

Twee malal werd de aortastomp gesloten door een protheserest in situ te laten en deze protheserest eirdstandig te sluiten. Bij 2 patiënten werd de aorta suprarenaal gesloten. Bï een van beide parienten werd de linker nierarterie gereconstrueerd met behulp wan de arteria liënalis en bij de ander werden de nieren niet gerevasculariseerd. Bij een pariën moest bij het sluiten van de stomp de linker nierarterie worden owerhecht, waarma nefrectomie plats vond en bif cén patiënt lukte her, ondanks vele overhechtingen, niet or de aortastomp woldoende diche te krijgen, wardoor deze patient tijdens de operatic overleed ren gevolge van exsanguinatie.

De soort hechtmateriaal waarmee de aorta werd gesloten, kon in 85 operatieverslagen $(74.6 \%)$ worden gevonden. In drie gevallen werd de stomp gesloten mer resorbeerbaar materiaal. In alle andere gevallen werd de aortastomp dichtgehecht met niet-resorbeerbaar hechtmateriaal. Bij twee patiënten werd gebruik gemaakt van mechanische nietapparatuur.

De wijze waarop de aortastomp, de aortotomie of de nieuwe prothese werd bedekt of afgeschermd van de viscera, werd in 84 operatieverslagen (73.7\%) teruggevonden. Elf maal kon her retroperitoneum worden gesloten en 4.8 keer werd het omentum majus daarvoor gebruikt. Bij 6 patiënten waten er voldoende resten van. het aneurysma of littekenweefsel aanwerig om de stomp re bedekken. Tweemaal werd het ligamentum longitudinale anterius losgemaakt van de wervelkolom en omgeklapt om de stomp te bedekken. In 17 gevallen werd bedekking niet nodig geacht of was er geen of onvoldoende weefsel voorhanden om de stomp of de nieuwe prothese te bedekken.

\subsubsection{BEHANDELING WAN DE DARM}

De behandeling van de gelaedeerde viscerale organen in geval wan een AEF varieerde van primair sluiten van de fistel, tot en met uitgebreide resectie mer primaire naad, of juist her vermijden van een darmnaad en inhechten van de darmeinden in de huid. Tabel 4.38 geeft een overzicht van deze behandelingen. 
Tabel 4.38. De behandeling varn de viscera bij AEF $n=62$

\begin{tabular}{|c|c|c|c|c|c|c|}
\hline \multirow{2}{*}{$\begin{array}{l}\text { behandeling prothese } \\
\text { behandeling darm }\end{array}$} & \multicolumn{2}{|c|}{ radical } & \multicolumn{2}{|c|}{ nee-radicaal } & \multicolumn{2}{|c|}{ totad } \\
\hline & $n$ & $\%$ & $\mathrm{n}$ & $\%$ & $n$ & $\%$ \\
\hline \multicolumn{7}{|l|}{ drodenun } \\
\hline primatir sluiten & 28 & 45.2 & 2 & 3.2 & 30 & 48.4 \\
\hline duodenojejunostonnie & 1 & 1.6 & - & - & 1 & 1.6 \\
\hline duodenumresectie & 4 & 6.5 & 1 & 1.6 & 5 & 8.1 \\
\hline onbekend & 1 & 1.6 & 1 & 1.6 & 2 & 3.2 \\
\hline rotatal & 34 & 54.9 & 4 & 6.4 & 38 & 61.3 \\
\hline
\end{tabular}

\section{jejunum}

$\begin{array}{lrrrrrr}\text { primair sluiten } & 7 & 11.3 & 2 & 3.2 & 9 & 14.5 \\ \text { resectie } & 3 & 4.8 & 1 & 1.6 & 4 & 6.5 \\ \text { abstineren } & - & - & 2 & 3.2 & 2 & 3.2 \\ \text { cotal } & 10 & 16.2 & 5 & 8.0 & 15 & 24.2\end{array}$

colon

$\begin{array}{lcccccc}\text { primair sluiten sigmoid } & 2 & 3.2 & - & - & 2 & 3.2 \\ \text { primair sluiren coecum } & - & & 1 & 1.6 & 1 & 1.6 \\ \text { Harmannproceture } & - & & 2 & 3.2 & 2 & 3.2 \\ \text { sigmoidresectie } & - & & 1 & 1.6 & 1 & 1.6 \\ \text { anus praeternaruralis } & - & & 1 & 1.6 & 1 & 1.6 \\ \text { rotaal } & 2 & 3.2 & 5 & 8.0 & 7 & 11.3\end{array}$

tractus mogenitalis

\begin{tabular}{lcccccc} 
ureterresectic & 1 & 1.6 & - & - & 1 & 1.6 \\
urerercatheter & 1 & 1.6 & - & - & 1 & 1.6 \\
total & 2 & 3.2 & - & - & 2 & 3.2 \\
& & & & & & \\
totaal & 48 & 77.6 & 14 & 22.4 & 62 & 100.0 \\
\hline
\end{tabular}

Van de 38 duodenale fistels werden er 30 primair gesloten. Bij een patient werd tegelijkentijd een manstompcarcinoom gereseceed. Na resectie werd rweemat de continuteit primair hersteld en bí één pariënt werden de beide uiteinden in de huid gehecht.

Van de 15 fistels nar her jejumum werden er 9 primair gesloten, ten keer in combinatie met cen hemicolecromie en werden er 4 met een resecte behandeld. Bij twee pasienten werd geabariw neerd: Bij een paxiënt werd na her stellen van de diagnose wegens de, ten gevolge van vele complicaties inmiddels zeer slecht geworden algemene taestand, bij het optreden van een abundante bloeding net meer operantef ingegrepen. Bij de tweede patient werd, nadat bij open buik de diagnose was gesteld, geabstineerd wegens irreversibele septische shock. 
Van de 7 colonfistels werden er 3 primair gesloten, eểnaal vond sigmoidresectie met primaire nad plaats. Tweemal werd een Hartmann procedure werricht en bij een patiènt werd alleen cen anus praeternaturalis aangelegd.

De parient met een geisoleerde fiste. naar de ureter werd behandeld door middel wan resectie van dric centimeter uneter, nadat in een vroeger stadium al een nefrostomie was angelagd vanwege matsale hematurie. Bij de patiènt met een aorto-uretero-enterale fistel werd een jejunumresecrie verricht " waana gepoogd werd een nefrostomie an te leggen. Toen dat niet lukte werd alleen een uretercatherer achtergelaten.

\subsubsection{REVASCULARISATIE}

Bij de 114 pariènten warbij de prothese geheel werd verwijderd werden 4 patiēnten autoloog, 2 patiẻnten in situ en 4 patiëncen nier gerevasculariseerd. Alle andere patiënten werden extra-anatomisch gerevasculariseerd. Deze 104 exrra-anatomische bypass operaties bestonden uit 11 unilaterale, en 93 bifemorale procedures. Bij de bifemorale bypass operacies kan nog onderscheid worden gemaakt tussen de bypass afgaande van de arteria axillaris aan een kant en de bilaterale axillo-femoralle bypasis.

Methode wan rewascularisatie bij de radicale behandeling $(n=114)$. De verdeling van de verschillende methoden woor de volgorde van verwijderen van de prothese en revascularisatie wordt weergegeven in tabel 4.39. De mogelijkheid 'geen revascularisatic" werd vier keer toegepast.

Tabel 4.39. Overzicht rijdstip en methode wan revascularisatie na radicale behandeling

\begin{tabular}{lcc} 
behandeling & $\mathrm{n}$ & $\%$ \\
\hline nradicioneel & 74 & 64.9 \\
sequenties & 19 & 16.7 \\
gestadiecd & 11 & 9.6 \\
autoloogy & 4 & 3.5 \\
in situ & 2 & 1.8 \\
geen & 4 & 3.5 \\
& & \\
totalal & 114 & 1.00 .0 \\
\hline
\end{tabular}

De raditionele methode, het verwijderen van de prothese en ansluitend aanleggen van een extra-anatomische bypass werd verreweg het meest in praktijk gebracht (64.9\%). Daama volgde de sequentiele methode, waarbij in én zitring eerst een extra-anatomische bypass werd geconstrueerd en aansluitend de prothese verwijderd $(16.7 \%)$. De gestadicerde procedure, waarbij eerst een extra-anatomische bypass werd aungelegd en op een larer tijdstip de prothese werd verwijderd, volgde in fre 
quentie hierna (9.6\%). Bij de gestadieerde procedure bedroeg de tijd russen het aanleggen wan dle extra-anatomische bypass en het verwijderen van de abdominale prothese mediaan 5 dagen, mer een minimum van 2 en een maximum van 96 dagen.

De autologe revascularisatie, ook genoemd de synchrone reconstructie ${ }^{267} \mathrm{kwam}$ maar 4 keer voor. Driemaal werd hierbij een thrombendarteriëctomie verriche van de iliacale vaten en eenmaal werd een enkelzijdige veneuze aorofemorale bypass aangelegd, na een eerdere contralaterale bovenbeensamputatie.

'In situ' revascularisatie met prothese, zonder latere vervolgbehandeling, lowam twee keer voor. Beide pariënten hadden een aorto-enterale fistel die werd gesloten, warna een nieuwe prothese werd ingebracht die werd afgedekt met een plastiek van her omentum majus.

Viermaal werd na radicale protheseverwijdering in het geheel géén revascularisarie verricht.

Een pariënt van 21 jaar, met de ziekre wan Boumeville, had een aortabuisprorhese wegens cen aneurysma die kon worden verwijderd zonder dat er ischemie van de benen optrad. Bij twee anderen ontstonden problemen met de aortastomp: een patiënt averleed op de operarietrafel ondat de aortastomp niet kon worden gesloten; de ander werd na sluiren van de aorcostomp gedurende twee maanden conservarief behandeld ondanks ischemische rustpijn en overleed als gevolg wan een 'blow out' van de aorrastomp alvorens tor de (geplande) revascularisatie kon worden overgegaan. Bij de vierde patiënt besrond er geen mogelijkheid om een extra-anatomische bypass te construeren wegens afsluicing van de arteriën waarop deze zou moeten worden aangesloten, warna 2 dagen later een dubbelzijdige heupexarticulatie moest worden verricht.

De extrat-anatomisch revascularisatic bij de radicale behandeling $(n=104)$. De revascularisatie bij de radicale behandeling berustte in 104 gevallen op het principe van de axillo(bi)femorale bypass (tabel 4.40).

Bij 88 patiënen werd een axillobifemorale revascularisatie verriche, waarbij in 4 gevallen het femoro-femorale traject met vene werd geconstrueerd.

Achtmaal werd een enkelzijdige axillofemorale bypass angelegd en cennaal een axillopopliteale bypass: Bij 2 pariënten werd een anastomose gemaakt met een teeds bestaande femoro-femoralc crossover bypass. Drie pariènten hadden reeds een bovenbeensamputatic ondergaan. Een patiën die tevoren een onderbeensampuratie had ondergaan en kreeg een axillofemoralic bypass aan de contralarerale zijde. Bij een patient werd na verwijderen van een buisprothese, een unilaterale axillofemorale bypass woldoende geache. De unilaterale axillo-popliteale bypass werd aangelegd bij een pariënt met een mycotische bloeding in de lies.

De revascularisatie bij de niet-radicale behandeling $(n=23)$. In de groep van 32 patiënten die niet-radicaal werden behandeld, vond bij 7 patiënten geen verwijdering van enig deel van de prothese plaats en werd ook geen revascularisatie verricht. Bij 25 patiënten werd de prothese parrieel verwijderd. Twee van deze laatste groep patiënten werden nier gerevasculariseerd, bij 18 patiënten werd een extra- 
Tabet 4.40. De cxara-anarom sche revascularisat enethoden bij de radicale behandeling, $\mathrm{n}=104$

\begin{tabular}{|c|c|c|c|c|c|}
\hline \multirow[t]{2}{*}{ Soort revascullarisatie } & \multirow{2}{*}{$\frac{\text { raditioned }}{n}$} & \multirow{2}{*}{$\frac{\text { gestadieerd }}{n}$} & \multirow{2}{*}{$\frac{\text { sequencied }}{n}$} & \multicolumn{2}{|c|}{ total } \\
\hline & & & & n & $\%$ \\
\hline -axillofemoral rechis & 2 & - & - & 2 & \\
\hline -axillofemonal links & 3 & - & 2 & 5 & \\
\hline -axillofemoral gekruist & & & & 1 & \\
\hline -axillopoplincal links & $\mathbb{1}$ & . & - & 1 & \\
\hline -naar cross-over & & 2 & & 2 & \\
\hline rotal unillateral: & & & & & 10.6 \\
\hline axillobifemoraal rechess afgarnd & 43 & 3 & 10 & 56 & \\
\hline -axillobifemoralal links afgaand & 20 & 6 & 6 & 32 & \\
\hline toraal axillobifemoral: & & & & & 84.6 \\
\hline axillofemoral en axillopoplitreaal & $\mathbb{1}$ & - & " & 1 & \\
\hline -axillopopliteaal bdz & 4 & - & . & 4 & \\
\hline cotsal bilaterad: & & & & & 4.8 \\
\hline totaal & 74 & 11 & 1.9 & 104 & \\
\hline
\end{tabular}

anatomische revascularisatie verricht en bij 5 patiënten werd een 'in situ' reconstructie vericht (tabel 4.41 ) In total werden dus 23 revascularisaties verricht bij de niet-radical behandelde patiënten.

Tabel 4.41. Revascularisatiemethoden bij de niet-radicale behandeling $n=23$

\begin{tabular}{|c|c|c|c|}
\hline revascularisatiemenode & $\mathrm{n}$ & & $\%$ \\
\hline -axillo-femoraal links & 2 & & \\
\hline axillo-distan rechts* & 2 & & \\
\hline axillo-distaal links & 1 & & \\
\hline foraal unilatermal: & & 5 & 21.7 \\
\hline -axillo-bifemoral reches & 1 & & \\
\hline -axillo-femoraal links on distat reches & 1 & & \\
\hline rotal axillobifemoral: & & 2 & 8.7 \\
\hline femoro-femoral veneus & li & & \\
\hline -fomoro-femoral kunstscof & 8 & & \\
\hline -obturator bypass & 2 & & \\
\hline totalal cross over bypass & & 11 & 47.9 \\
\hline "in siru" mat prothese & 5 & 5 & 21.7 \\
\hline rotaal & 23 & 23 & 100.0 \\
\hline
\end{tabular}

" "distial' is distatl van de lies 


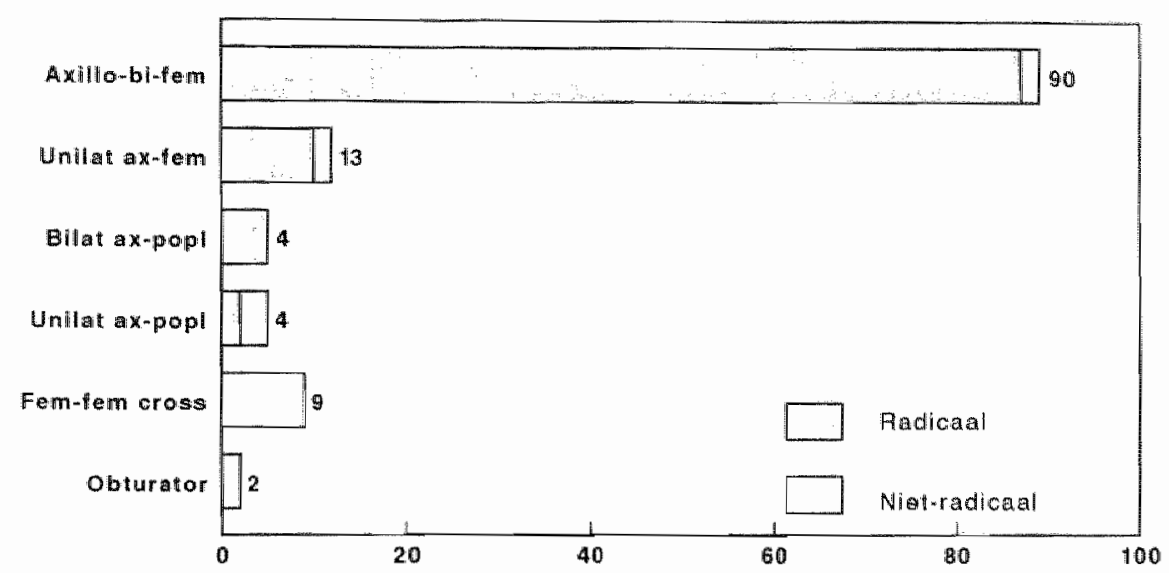

Figuur 3. overzicht van alle extra-anatomische bypass procedutes bij zowel radicaal ais niet radicaal behandelde patiënten. $(n=122)$

Bij de patiẻnten die nier werden getevasculariseend ging her om én patiënt, waarbij rijdens de primaire operatie, die werd verricht wegens claudicarie, de distale anastomose op ilacal niveau was gelegd. Hierbij werd alleen een protheseben werwijderd waarna slechts daticatie resteerde. Bij de rweede patiën betrof het een prothesebeen dat reeds jaren was afgesloten.

De 5 patiënten, die na partiele prothesewerwijdering 'in situ' werden gerevasculariscerd ondergingen verschillende behandelingen. Bij eén patiènt werd het proximale deel van de prothese wervangen door een nieuwe prothese, bedekt met een omentumplastiek. Bij 3 patienten werd na het verwijderen van een prothesebeen, en nieww prochese-interponat angebtach tussen de oorspronkelijke prothese en respecrievelijk de arteria femoralis communis en de arteria jiaca externa. Bij de vijfde parient kon een pereutane transluminalc angroplastick wan de arteria ilitaca communis worden verricht.

Een overzicht van alle extra-anatomische bypass procedures zoals deze bij alle bereffende patiënten werden toegepast wordt gegeven in figur 3 .

\section{4 .8 WONDBEHANDELING}

Bebandeling wan bet prothesebed. De restholte die overblift na verwijderen wan de prothese kan worden opgevuld of gedraineerd. Bij 31 parienten werd over dit asspect van de behandeling niets vermeld of er werden geen speciale maarregelen genomen. Bij de andere 84 parienten werd 44 mal het omentum majus gebruikt om de restholte op te vullen en in 24 gevallen werd een dranagesysteem achterge aten. 
Zesmaal werd lokaal een antibioticum achtergelaten en bij 9 pariènten werd een combinatie van locale antibiotica en drainage toegepast.

In de groep niet-radicaal behandelde patiènten werd in 3 gevallen het nier verwijderde deel van de prorhese afgeschermo met een omentumplastiek; een keer in combinatie met een drainagesysteem. Vijfmaal werd lokaal een antibioticum achtergelaten en tweemaal werd uitsluitend een drain achtergelaten. Bij de rest van de patienten werd in het operatieverslag niets hierover vermeld.

Betuandeling van de chirurgische wond. De behandeling wan de laparotomiewond bij de chirurgische behandeling wan de prothese-infecties kon worden geregistreerd bij 136 pariénten (88.3\%). Bij 36 patiënten werd de huid open gelaten en in $1.3 \%$ werd de buik gesloten mer behulp van een Vicryl matje (tabel 4.42).

Tabel 4.42. Behandeling van de buikwond bij de behandeling van de prothese-infecties

\begin{tabular}{lrr}
\hline behandeling & $\mathrm{n}$ & $\%$ \\
\hline open & 36 & 23.4 \\
primair gesloten & 98 & 63.6 \\
vicrylmatjo & 2 & 1.3 \\
onbekend & 18 & 11.6 \\
& & \\
toraal & 154 & 100.0 \\
\hline
\end{tabular}

Bij slechts 64 patiënten (41.6\%) werden mededelingen in het dossier gedaan over de behandeling van de lieswond, waaruit de prothese werd verwijderd.(tabel 4.43)

Tabel 4.43. Behandeling van de lieswond bij de behandeling van de prorhese-infecties

\begin{tabular}{lrc}
\hline behandeling & n & $\%$ \\
\hline open & 22 & 34.4 \\
gesloten & 36 & 56.2 \\
lokaal antibiotical & 5 & 7.8 \\
sarrortusplastick & 1 & 1.6 \\
toraal & 64 & 100.0 \\
\hline
\end{tabular}

\subsection{MICROBIOLOGIE}

Het gram prepatraat. Bij de behandeling van 34 patiënren werd melding gemaakt van thet resultaat van een grampreparaat durante operationem. Zeven van deze grampreparaten $(22.1 \%)$ leverden geén aanwijzingen op voor de aanwezigheid van micro-organismen. 
Van de 7 patiènten mer negatieve gram preparaten bij operatie werd bij 2 macroscopisch pus gevonden en bij twee paciënten was een wondkweek bij opname beschikbaar waaruit $S$ aureus was gekweekt; bij de een uit een abces in de lies en bij de ander uit een sinus in de lies met een posirief fistulogram. Bij beiden was het gram preparaat dus niet meer van doorslaggevende berekenis. Bij de vijfde patient werd al vóór de operatie zowel bij CT punktie als uit her bloed Sepidermidis gekweekt, waardoor de diagnose ook al preoperatief duidelijk was. Een patiënt had een geruptureerd aneurysma spurium in de lies met vocht rond de prothese en koorts met leucocytose en de zevende had een geruptureerd aneurysma spurium op de distale iliacale anastomose met een geheel losliggende prorhese.

Bacteriekweek. De resultaren wan de kweek van de prothese of weefselvocht werden bij 10.1 van de behandelde patiënten achterhaald $(65.6 \%)$ Bij de radicale behandeling werd 80 keer de uirslag van microbiologisch onderzoek getraceerd $(71.4 \%)$ en bij de niet-radicale behandeling 21 keer $(66.6 \%)$. In 71 gevallen werden pathogene micro-organismen aangetoond (70.9\%), terwijl 30 kweken $(29.1 \%)$ geen groei opleverden De aard van het gekweekte micro-organisme wordt vermeld in tabel 4.45. Bij statistische analyse werd geen significante relatie gevonden tussen vroeg of laat optredende infecties en de aard van de gevonden micro-organismen bij kweek of in het durante operationem gemaakte grampreparaat .

Tabel 4.45. Gekweekte micro-organismen wit het durante operationem afgenomen materiaal.

\begin{tabular}{|c|c|c|c|c|c|}
\hline \multirow[b]{2}{*}{ micro-organisme } & \multicolumn{2}{|c|}{ radicale behandeling } & \multicolumn{2}{|c|}{ niet-radicale behandeling } & \multirow[t]{2}{*}{ rotial } \\
\hline & PGI & $\mathrm{AEF}$ & $\mathrm{PGI}$ & $A \mathbb{E F}$ & \\
\hline Gr pos coccer & 37 & 7 & 7 & 2 & 33 \\
\hline Gram negatieven & 9 & 4 & 1 & 2 & 16 \\
\hline Anaèroben & 3 & 1 & 1 & - & 5 \\
\hline Mengfiora & 3 & 13 & - & - & 16 \\
\hline Gram pos staven & 2 & - & - & 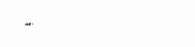 & 2 \\
\hline geen groei & 18 & 3 & 6 & 2 & 29 \\
\hline totaal & 52 & 28 & 15 & 6 & 101 \\
\hline
\end{tabular}

In toral werden 37 monoculturen op $(36.6 \%)$ gekweetst. In de groep gram positicuc cocen werden 11 kweken gevonden mer meerdere gram positieve cocen en 21 monoenlturen be-

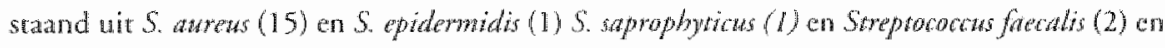
Streptocontus bamolyticus (2). De 16 gram negateve kweken bestonden wit 4 mer meerdere gramnegatieven en 12 monoculuren van E coli (8), Khbsiella (1). Morganella (2). Psesdomonats (1). De groep anaeroben was samengesteld uit 3 monocultaren mer Bacteroides (2), en Coryabacteriw (1) en 2 waabij ook gram positieve of gram negatieve coccen werden gekwedkt. Bij én pariène werd Prapioni bacterium gekweekt. De groep mengfiora was zecr divers en bestond 
uir combinaties van gram positicve en gram negatieven en anaëroben en kweken waabij daarnaast ook nog andere bacterien werden gekweekt (12).

\subsection{DE RESULTATEN VAN DE BEHANDELING}

\subsection{TNLEIDE}

De gegevens betreffende de overleving en opnameduur zijn van alle pariënten bekend. Over de post-operatieve complicaries tijdens opname in het ziekenhuis waren nier alle gegevens te achterhalen. Van 24 patienten $(15.6 \%)$, waarvan de helf post-operatief owerleed, waren over de periode aansluitend aan de operatie weinig. tot geen gegevens over het post-operavieve beloop terug te vinden. Meestal was het ontbreken wan deze gegevens gevolg wan het ontbreken van intensive care dossiers, ondat verpleegkundige gegevens vaak niet bij het medisch dossier, waarvan de bewaarermijn langer is, werden bewaard. Voor de berekening van de duur van de opname, ICU-verpleging, beademing en complicaries zijn de gegevens verwerkt van alle patienten, waarvan deze gegevens achterhaald werden. Bij de berekening van de operatiemortaliteit zijn de patiënten, warbij wan verdere behandeling werd afgezien ( 8 patiënten, $5.2 \%$ ), buiten beschouwing gelaten.

\subsubsection{VERPLEEGDUUR EN BEADEMING}

De opnameduur, berekend wanaf de datum van de behandeling van de infecrie van de geinfecterde prothese tot de ontslagdatum of de datum van overlijden was van alle patiënten bekend. (zie tabel 4,46)

Tabel 4.46. Opnameduur in dagen

\begin{tabular}{|c|c|c|c|c|}
\hline & $n=$ & gemiddeld & $s \mathrm{~d}$ & medianan \\
\hline \multicolumn{5}{|c|}{ radicaal behandeld } \\
\hline owerlexendon & 63 & 33.3 & 20.7 & 25.0 \\
\hline overledenen & 51 & 15.6 & 21.9 & 9.0 \\
\hline \multicolumn{5}{|c|}{ nier-radicat bothandeld } \\
\hline overtevenden & 26 & 29.9 & 28.6 & 18.0 \\
\hline overledenen & 14 & 9.4 & 13.2 & 5.0 \\
\hline cotaal & 154 & 24.7 & 23.7 & 18.0 \\
\hline
\end{tabular}


De duur van de post-operatieve ICU verpleging is vermeld in rabel 4.47. Achrtien patiènten ( $14.0 \%$ van degenen waarwan gegevens bekend zijn) lagen langer dan 20 dagen op de afdeling intensive care. Hiervan verlieten er 6 levend het ziekenhuis.

Tabel 4.47. Duur post-operatieve ICU verpleging

\begin{tabular}{|c|c|c|c|c|c|c|}
\hline & \multicolumn{2}{|c|}{ radicaal behandeld } & \multicolumn{2}{|c|}{ niet-radical behandeld } & \multicolumn{2}{|c|}{ rotaal } \\
\hline & n & $\%$ & $\mathrm{n}$ & $\%$ & n & $\%$ \\
\hline gyen & 4 & 3.5 & 6 & 15.0 & 10 & 6.5 \\
\hline$<24$ unr & 10 & 8.8 & 11 & 27.5 & 21 & 13.6 \\
\hline 1.5 dagen & 39 & 34.2 & 7 & 17.5 & 46 & 29.9 \\
\hline $6-20$ dagen & 27 & 23.7 & 6 & 15.0 & 33 & 21.4 \\
\hline 20 dagen & 15 & 13.2 & 3 & 7.5 & 18 & 11.7 \\
\hline onbekend & 19 & 16.7 & 7 & 17.5 & 26 & 16.9 \\
\hline toraal & 114 & 100.0 & 40 & 100.0 & 154 & 100.0 \\
\hline
\end{tabular}

Het merendeel van de patiënten $(88.3 \%$ ) werd postoperarief beademd (tabel 4.48). Elf patiënten $(9.0 \%$ van degenen waarvan gegevens bekend zijn) werden langer dan twintig dagen beademd. Hiervan verlieten er slechts 3 levend het ziekenhuis.

Tabel 4.48. Duur post-operarieve beademing

\begin{tabular}{|c|c|c|c|c|c|c|}
\hline & \multicolumn{2}{|c|}{ radicalal behandeld } & \multicolumn{2}{|c|}{ niet-radicaal behandeld } & \multicolumn{2}{|c|}{ total } \\
\hline & $n$ & $\%$ & $\mathrm{n}$ & $\%$ & $\mathrm{n}$ & $\%$ \\
\hline geen & 6 & 5.3 & 12 & 30.0 & 18 & 11.7 \\
\hline$<24$ uแ & 25 & 21.9 & 10 & 25.0 & 35 & 22.7 \\
\hline $1-5$ dagen & 27 & 23.7 & 3 & 7.5 & 30 & 19.5 \\
\hline 6-20 dagen & 21 & 18.4 & 6 & 15.0 & 27 & 17.5 \\
\hline$>20$ dagen & 10 & 8.8 & 1 & 2.5 & 11 & 7.1 \\
\hline onbekend & 25 & 21.9 & 8 & 20.0 & 33 & 21.4 \\
\hline totaal & 114 & 100.0 & 40 & 100.0 & 154 & 100.0 \\
\hline
\end{tabular}




\subsubsection{Complicaties van de vitale organen}

Gegevens over postoperatieve orgaanschade werden achterhaald bij gemiddeld $131(89.7 \%$ ) van de 146 behandelde patiënten (zie tabel 4.49$)$. In totaal werden 131 postoperatieve complicaties van organen of orgaansystemen geregistreerd bij 74 wan de behandelde patiënten $(50.7 \%)$, hetgeen neer komt op gemiddeld 1.8 virale complicaties per behandelde patiënt. In de radicaal behandelde groep werden de betreffende gegevens achterhaald bij gemidcleld 102 van de 114 patiènter $(89.5 \%)$ en hierbij werden bij 62 patiënten (60.8\%) 111 complicaties van de vitale organen geregistreerd. Bij de nier-radicaal behandelde parienten werden de gegevens achterhaald van gemiddeld 29 van de 32 patiënten $(90.6 \%)$, warbij 20 complicaties werden gevonden bij 12 pariënten (41.4\%). Dit betekent voor de radicaal behandelde patiènten gemiddeld 1.8 en voor de niet-radicaal behandelde pariënten gemiddeld 1.7 complicaties van de vitale organen per patiënt. Dit verschil is niet significant. $(\mathrm{p}=0.09)$

Pulmonale complicates. Gegevens waren te achterhalen van 132 patiënten (90.4\%). Tweemaal ontstond een pneumothorax. De belangrijkste andere pulmonale complicaties betroffen bronchopneumonie (36) en adult respiratory distress syndrome (23) volgens de gebezigde definitie onder sectie 3.3.5.2. Er was geen significant verschil tussen de radicale behandeling en de niet-radicale behandeling. Cartiale complicaties. Deze gegevens werden achterhaald van 121 patiënten (82.8\%) Er waren 6 patiènten met een hartinfarct waarvan er 2 aan cardiale oorzaken overleden. Twee andere patiënten overleden aan een 'blow out' van de aortastomp en aan sepsis en twee patiënten konden levend het ziekenhuis verlaten. Elf patiènten moesten worden behandeld wegens decompensatio cordis. Er was geen significant verschil russen de radicale behandeling en de nier-radicale behandeling. Neurologishe complicaries. Elf patienten van de 135 patienten $(92.4 \%$ ) warvan de gegevens te achrerhalen waren, hadden neurologische complicaties (8.1\%). Negenmal betrof dit cen cerebrovasculair accident terwijl in de groep radical behandelde patiënten eenmal cen gegeneraliseerde insult en eenmaal een irreversibele dwarshesie voorkwam. Er was geen significant verschil tussen de radicale behandeling en de niet-radicale behandeling.

Nierfuctiesoomissen. In total werden post-operatief 23 patienten (17.0\% van de 137 warvan gegevens beschikbaar waren) anurisch $(16.8 \%)$. In de niet-radicale groep werden 4 pariënten (13.3\%) anurisch en in de 'radicale groep' berrof her 18 parienten (17.8\%). Eén patient was pre-operatief al dialysebehoeftig. Bij 13 patiënten werd overgegaan tot dialyse, de 10 anderen werden niet gedialyseerd. Van de torale groep patiënten met anurie hebben 3 patiënten het ziekenhuis levend 
werlaten. Er was geen significant werschil tussen de radicale behandeling en de niet-radicale behandeling.

Mulaiple organ failure. De diagnose $\mathrm{MOF}$, volgens de gehanteerde definitie voor dit syndroom (3.3.5.2) werd 19 keer geregistreerd (14.6\%) bij 130 patiënten. Alle patiënten mer deze complicatic overleden. Het verschil tussen radicale en niet-radicale behandeling was niet significant. Evenmin bleek er een significante relatie te bestaan tussen de frequentie van optreden van deze complicaties en her wroeg of laat optreden van de infecrie.

Tabel 4.49. Owerzicht van de postoperatieve complicaties van de vitale organen bij de patienten warvan de gegevens te achterhalen waren

\begin{tabular}{|c|c|c|c|c|c|c|c|c|c|c|}
\hline \multirow[b]{2}{*}{ complicárie } & \multicolumn{3}{|c|}{ radical behandeld } & \multicolumn{3}{|c|}{ nier radical behanded } & \multicolumn{3}{|c|}{ rotatal } & \multirow[b]{2}{*}{$p$} \\
\hline & $\mathrm{n}=$ & ancal & $\%$ & $n=$ & aantal & $\%$ & $\mathrm{n}=$ & aankal & $\%$ & \\
\hline pulmonaal & 102 & 52 & 51.0 & 30 & 9 & 30.0 & 132 & 61 & 46.2 & 0.07 \\
\hline cardiaal & 94 & 13 & 13.8 & 27 & 4 & 14.8 & 121 & 17 & 14.0 & 09 \\
\hline neurologisch & 105 & 10 & 9.5 & 30 & 1 & 3,3 & 135 & 11 & 8.1 & 0.2 \\
\hline nefrologisch & 107 & 18 & 17.0 & 30 & 4 & 13.3 & 137 & 22 & 16.0 & 0.6 \\
\hline MOF & 101 & 17 & 16.8 & 29 & 2 & 6.9 & 130 & 19 & 1.4 .6 & 0.2 \\
\hline
\end{tabular}

\subsubsection{Bloedingscomplicaties}

Een overzicht van de bloedingscomplicaties die optraden bij en na de operatieve behandeling van de geinfecteerde abdominale vaarprothese wordt gegeven in tabel 4.50 . Insufficientie van de arortastomp ('blow out'). Insufficiëntie van de aortastomp of de aortotomie werd in de post-operatieve lase 9 keer $(7.9 \%)$ waargenomen bij $114 \mathrm{ra-}$ dicaal behandelde patiènten. (zie tabel 4.48) Alle paniënten overleden hieraan nog rijdens de opname na gemiddeld 44 dagen. In 5 gevallen kon de diagnose bij obductie worden bevestigd. Bij de niet geobduceerde patiënten werd de diagnose gesteld op basis van de klinische presentatie

Bij 2 pariënten presenteerde de insufficièntic van de aortasnomp zich als cen recidief bloeding uir de tractus digestivus: een maal een massale 'maagbloeding' en een maal een bloeding uir de in de huid gehechte duodenumstomp. De twee andere patiènten overleden ten gevolge wan cen hypovolemische shock, die door de behandelaar werd geinterpretecrd als gevolg varn insufficiëntic van de aortastomp.

Abdominale nabloedingen. Onder de diagnose "nabloeding" moest bij de radicaal behandelde pariënten in 8 gevallen een relaparotomic worden verricht $(5.5 \%)$. Meestal bleek er, behalve de nabloeding, andere parhologie in her spel, wardoor, in de meerderheid van de gevallen, meerdere laparotomieën werden verricht. Bij 
de niet-radicaal behandelde patiënten waren geen relaparotomien wegens nabloeding noodzakelijk.

Nabloeding, sanenhangend met de extratanatomische bypass. Alleen bij de radicaal behandelde patiënten werd 2 keer een nabloeding geregistreerd (1.9\%) op een van de anastomosen van de axillofemorale bypass. In beide gevallen was de nabloeding axillair gelokaliseerd.

Een van de patiênten kreeg daarna een infectie van de axillofemorale bypass, die 11 maanden later leidde tot verwijderen van de bypass. De ander overleed korte rijd later aan een andere oorzaak.

Bloeding wit de tractus digestivus. Behalve de bloedingen uit de tractus digestivus die optraden bij de recidief aorto-enterale fistels (zie onder 'blow out') trad er bij de niet-radicaal behandelde patiënten eenmaal een nabloeding uit de bovenste tractus digestivus op (3.1\%) zeven dagen na overhechten van het duodenum wegens aorto-enterale fistel.

Er werd hiervoor een relaparotomie verrichr met duodenotomie warbij geen bloeding werd gevonden. Patiént overleed wegens multiple organ failure op de vifftiende post-operarieve dag. Stollingsstoomissen. In de groep radicale behandeling werd bij 8 patiënten (5.5\%) in het dossier melding gemaakt van stollingsstoornissen. Bij de niet-radicale behandeling trad deze complicatie tweemaal op (6.2\%). Alle 10 patiënten overleden. De erbij behorende laboratoriumuitslagen van stollingsonderzoek waren in vrijwel geen dossier te vinden. $\mathrm{Bij} 4$ patiënten is de stollingsstoornis te beschouwen als belangrijkste oorzaak van overlijden. Bij de zes anderen was de stollingsstoornis mede oorzaak van her overlijden.

Tabel 4.50. Overzicht van alle vroeg postoperatieve bloedingscomplicaties.

\begin{tabular}{|c|c|c|c|c|c|c|c|c|c|}
\hline \multirow[b]{2}{*}{ Blocding } & \multicolumn{3}{|c|}{ radicaal behandeld } & \multicolumn{3}{|c|}{ nier-radicaal behandeld } & \multicolumn{3}{|c|}{ totaal } \\
\hline & $n=$ & aantal & $\%$ & $n=$ & aancal & $\%$ & $n=$ & aancal & $\%$ \\
\hline \multicolumn{10}{|l|}{ insufficientic } \\
\hline v.d. anorta(stomp) & 114 & 9 & 7.9 & - & - & - & 146 & 9 & 6.2 \\
\hline abdominale blocding & 114 & 8 & 7.0 & 32 & - & - & 146 & 8 & 5.5 \\
\hline \multicolumn{10}{|l|}{ Bloeding extra- } \\
\hline anatomixche bypass & 104 & 2 & 1.9 & 18 & - & - & 122 & 2 & 1.6 \\
\hline bloeding or digestivus & 114 & - & - & 32 & 1 & 3.1 & 137 & 1 & 0.7 \\
\hline stollingsstoornissen & 114 & 8 & 5.5 & 32 & 2 & 6.2 & 146 & 10 & 6.8 \\
\hline
\end{tabular}




\subsubsection{Seprische complicaties}

Wondabeessen. Wondinfecties van de abdominale wond deden zich voor bij $9 \mathrm{pa-}$ tiënten $(7.1 \%)$ warvan er 2 , beide in de radicaal behandelde groep, operatief behandeld werden. Wondinfecties van de lieswonden ontstonden bij 7 pariènten met een lieswond $(7.4 \%)$, waarvan er vijf operatief gedraineerd werden.

Sepsis. Sepsis, volgens de gebezigde definitie (zie 3.3.2.1) werd geregistreerd bij 47 patiënten $(37.3 \%)$ van de 126 met complete gegevens wat dit aspect betreft. (tabel 4.50)

In de radicaal behandelde groep trad sepsis op bij 42 patiënten, (42.9\%) warvan er slechts 9 levend het ziekenhuis verlieten. Bij de nier-radicaal behandelde patiënten ontsrond postoperatief 5 keer $(17.9 \%)$ een systemische sepsis, waarvan slechts één patiënt levend het ziekenhuis kon verlaten. Dir blijkt een significant verschil te zijn. $(\mathrm{p}=0.02)$

Infectie van de extra-anatomische bypass. In totaal werd bij 122 patiënten een extraanatomische bypass aangelegd, 104 in de radicaal behandelde groep en 18 bij niet-radicaal behandelde patiënten. Na radicale behandeling werd 5 keer een vroege infectie van de extra-anatomische bypass waargenomen (4.1\%).

Driemaal werd de infectie van de extra-anatomische bypass operatief behandeld: Door middel van een gracilisplastick (1), een huidplastick (1) en door een aneurysma spurium te behandelen met een veneuze parchplastiek. Bij een patiënt ontstond astma cardiale wóór behandeling kon worden ingesteld. Eenmaal werd de infecrie per roeval gevonden, toen de bypass in cen diverriculair abces bleek te liggen. Her abces werd gedraineerd en de prothese bleef in situ. patiènt overleed 4 dagen larer an een abdominale sepsis.

Na nier-radicale behandeling werd één vroege infectic $(5.5 \%)$ van de extra-anaromische bypass gemeld.

Her betrof en patienn waarbij wegens een perigraft-infectic een prothesebeen werd verwijderd en revascularisatie werd verriche door her aanleggen van een axilloribiale bypass. Na thrombectomie ontstond een recidief afsluiting, waarna een knie-exarticularic noodzakelijk werd. Vier dagen later volgde een bovenbeensampuratie. Pariënt overleed 21 dagen na verwijgleren van her prothesebeen aan multiple organ failure.

Abdominale seprische complicaties. Septische complicaties in de buik werden in 26 gevallen gezien na radicale behandeling $(22.8 \%)$ en na niet-radicale behandeling bij én pariënr (3.1\%). Dit verschil is statistisch significant. $(p<0.02)$

Vierentwintig patiënten werden én of meerdere keren opnieuw geopereerd voor abcesdrainage en/of darmresectie. Tweeëntwintig van de 27 patiënten met een septisch buikbeeld maakten ook een systemische sepsis door. Negentien van deze pariënten overleden tijdens de opname $(70.0 \%)$. De septische abdominale complicaties zijn samengevar in tabel 4.51 . 
Tabel 4.51. Septishe buikconplicaties bij de behandeling van de geinfecteerde abdominale watprothese

\begin{tabular}{lcr}
\hline conzale & $\mathrm{n}$ & \multicolumn{1}{c}{$\%$} \\
\hline Darmnecrose* & 7 & 25.9 \\
omencumnecrose & 1 & 3.7 \\
purulente peritonitis & 3 & 11.1 \\
pancrearitis & 1 & 3.7 \\
buiksepsis zonder operatic & 3 & 11.1 \\
intra-abdominale abcessen & 12 & 44.4 \\
& & \\
total & 27 & 100.0 \\
\hline
\end{tabular}

* inclusief ischemische colinis

Een overzicht van de septische complicaties bij de operatieve behandeling van de infecties van de abdominale vaatprothese word gegeven in tabel 4.52 . Her verschil tussen het sepsispercentage bij de radicale en bij de niet-radicale behandeling is nier significant. De septische complicaties van de exrra-anatomische bypass voor beide behandelingsvormen tonen géén significant verschil. Het optreden van zowel 'systemische sepsis' als 'abdominale sepsis' was bij de vroege infecties (zie 4.3.1) wel significant hoger dan bij de laat optredende infecties $(\mathrm{p}<0.02)$.

Tabel 4.52. Overzicht postoperaticve septische complicaties.

\begin{tabular}{|c|c|c|c|c|c|c|c|c|c|}
\hline \multirow[b]{2}{*}{ infect } & \multicolumn{3}{|c|}{ radicaal behandeld } & \multicolumn{3}{|c|}{ niet-radicaal behandeld } & \multicolumn{3}{|c|}{ rotalal } \\
\hline & $n=$ & atantal & $\%$ & $\mathrm{n}=$ & zancal & $\%$ & $n=$ & aancal & $\%$ \\
\hline systemenche sepsis & 98 & 42 & 42.9 & 28 & 5 & 17.9 & 126 & 47 & 37.3 \\
\hline abdominale sepsis & 114 & 26 & 22.8 & 32 & 1 & 3.1 & 146 & 27 & 18.5 \\
\hline \multicolumn{10}{|l|}{ Dexra-anatumische } \\
\hline bypuss & 104 & 5 & 4.8 & 18 & $\mathbb{1}$ & 5,5 & 122 & 6 & 4.9 \\
\hline
\end{tabular}

\subsubsection{Complicaties van de extra-anatomische bypass}

In total deden zich 38 complicaties (thrombose, nabloeding en infectie) van de kant van de exrra-anatomische bypass voor bij 23 patiënten. (tabel 4.53) De infecties van de extra-anatomische bypass werden reeds beschreven onder 'septische complicaties' (4.5.3.3) en de nabloedingen onder 'bloedingscomplicaties'. (4.5.3.2)

$\mathrm{Na}$ de radicale behandeling werd acure afsluiting van de extra-anatomische bypass warvoor thrombectomie werd verricht 26 keer bij 18 patiënten waargenomen $(17.3 \%)$. Bij 3 patiënten was twee keer een thrombectomie noodzakelijk en bij éen 
patient zes keer. Bij een paciënt werd, ter vook koming van re-thrombosering, de bypass verlengd tor op de arteria profunda femoris. In de niet-radical belinandelde groep moest bij 2 patienten $(11.1 \%$ ) en thrombectomie worden verticht uit een axillobifemorale bypass $(13 \%)$.

Tabel 4.53. Overzicht van de postoperarieve complicaties van de extra-anatomische bypass.

\begin{tabular}{|c|c|c|c|c|c|c|}
\hline & \multicolumn{2}{|c|}{$\begin{array}{l}\text { radican behandeld } \\
n=104\end{array}$} & \multicolumn{2}{|c|}{$\begin{array}{l}n=18 \\
n=1 \text {-radical behandeld }\end{array}$} & \multicolumn{2}{|l|}{$\begin{array}{l}\text { tocal } \\
n=122\end{array}$} \\
\hline & aantall & $\%$ & aantal & $\%$ & Nantal & $\%$ \\
\hline thrombose & 18 & 17.3 & 2 & 11.1 & 20 & 16.4 \\
\hline infecrie & 5 & 4.8 & 1 & 5.5 & 6 & 4.9 \\
\hline bloeding & 2 & 1.9 & - & - & 2 & 1.6 \\
\hline
\end{tabular}

\subsubsection{Amputaties}

Amputaties werden in de groep radicale protheseverwijdering in de post-operatieve Gase verricht bij 7 patiënten $(6.1 \%)$.

Het betrof een onderbeensamputatie, een knie-exarticulatic, twee bovenbeensamputaties en een te-amputatie van een reeds cerder geamputeerd bovenbeen. Bij de enige pariënt waarbij ren gevolge van arteriële afshitingen, een extra-anatomische omleiding technisch niet realiseerbaar bleek, moest een dubbelzijdige heupexarticulatie worden verricht.

In de groep niet-radicale behandeling was in de vroege post-operavieve fase eenmaal een bovenbeensamputatie noodzakelijk $(3.1 \%)$ wegens infectic van de extra-anatomische bypass.

\subsubsection{Ischemische colitis}

Ischemische colitis werd 5 keer (4.4\%) geregistreerd bij de radical geopercerden en eenmaal bij de niet-radicaal behandelde patiënten $(3.1 \%$. Een keer werd de diagnose pas bij obductie gesteld. Bij 4 parienten werd operarief ingegrepen (colonresectie) en bij éen patiènt was her beloop zodanig dat operatie niet noodzakelijk. werd.

\subsubsection{De hospitaalmortaliteit}

Van de 154 patienten met een geïfecteerde abdominale vaatprothese overleden in totaal 64 patienten ( $41.6 \%$ ) in het ziekenhuis. (tabel 4.54 ) Er waren 8 patienten, waarbij na het stellen van de diagnose van operatieve behandeling werd afgezien. Hiervan ovetleden er 5 en konden er 3 levend het ziekenhuis verlaten. 
Van de 146 paternten die operatief werden behandeld (cabel 4.54) overleden er 59 $(40.4 \%)$.

Ten arazien van de behandeling, radical of nict-radicaal, berekend voor de hele groep bleck er geen sign fifcant verschil in operatiemortaliteit. Alleen de niet-radicale behandeling van de $P G I$ had een significant hogere overleving dan de radicale behandeling van de AEF. $(p=0.008)$

Tabel 4.54. Oxerachr wan de operatiemortaliteir gerelateerd aan diagnose en betandeling

\begin{tabular}{|c|c|c|c|c|c|c|c|c|c|}
\hline \multirow[b]{2}{*}{ behandeling } & \multicolumn{3}{|c|}{ PGI } & \multicolumn{3}{|c|}{ AEF } & \multicolumn{3}{|c|}{ iotal } \\
\hline & $n=$ & mort & $\%$ & $n=$ & morr & $\%$ & $n=$ & mort & $\%$ \\
\hline radicaal & 66 & 28 & 42.4 & 48 & 22 & 45.8 & 114 & 50 & 43.9 \\
\hline nier-radicaal & 20 & 2 & 10.0 & 12 & 7 & 58.3 & 32 & 9 & 28.1 \\
\hline totaal & 86 & 30 & 34.9 & 60 & 29 & 48.3 & 146 & 59 & 40.4 \\
\hline
\end{tabular}

De operatiemortaliteit wan de zich vroeg manifesterende infecties (binnen 4 maanden) bleck significant hoger te zujn dan die van de laat optredende infecties. $(p=0.001)$ Dit verschil bleek voornamelijk te berusten op de hoge operatiemortaliteit van de radicale behandeling van de vroeg optredende PGI.(tabel 4.55)

Tabel 4.55. Overzicht van de operatiemortaliteir gerelateerd aan het rijdstip van presentatie

\begin{tabular}{|c|c|c|c|c|c|c|c|c|c|}
\hline \multirow[b]{2}{*}{ presentaric } & \multicolumn{3}{|c|}{ PGI } & \multicolumn{3}{|c|}{ AEF } & \multicolumn{3}{|c|}{ totaal } \\
\hline & $\mathrm{n}=$ & mort & $\%$ & $n=$ & mort: & $\%$ & $n=$ & mort & $\%$ \\
\hline $\operatorname{vroeg}(\ll 4 \mathrm{mnd})$ & 46 & 24 & 51.2 & 8 & 7 & 87.5 & 54 & 31 & 57.4 \\
\hline latat (>4 annd) & 40 & 6 & 15.0 & 52 & 22 & 42.3 & 92 & 28 & 30.4 \\
\hline tocaal & 86 & 30 & 34.9 & 60 & 29 & 48.3 & 146 & 59 & 40.4 \\
\hline
\end{tabular}

\subsubsection{Doodsoorzaken}

De doodsoorzaken, zoals ze door de behandelaar in her dossier werden genoteerd of bij obductie werden vastgesteld, van de 60 patiënten die perioperatief overleden zijn vermeld in tabel 4.56 . Obductie werd bij 28 patienten verricht en bij 32 andere patiënten werd de doodsoorzak in het dossier aangegeven. 
Tabel 4.56. Doodsoorzaken van de perioperatief overleden patièuren

\begin{tabular}{|c|c|c|c|c|c|c|}
\hline \multirow[b]{2}{*}{ doodsoorzadk } & \multicolumn{2}{|c|}{ radicale behandeling } & \multicolumn{2}{|c|}{ niet-radicale behandeling } & \multicolumn{2}{|c|}{ rotal } \\
\hline & $n$ & $\%$ & $\mathrm{n}$ & 喻 & n & $\%$ \\
\hline per/perioperacieve verbloeding & 5 & 8.4 & 3 & 5.0 & 8 & 13.5 \\
\hline insufficiëntie aortastomp & 9 & 15.0 & - & 9 & 15.0 & \\
\hline sepsis tgy prothese infekt & 14 & 23.4 & 4 & 6.7 & 18 & 30.0 \\
\hline abdominale sepsis & 13 & 21.6 & - & 13 & 21.6 & \\
\hline ischemie vid.extremiteiten & 2 & 3.3 & - & 2 & 3.3 & \\
\hline hartallen & 2 & 3.3 & 1 & 1.6 & 3 & 5.0 \\
\hline neurologische afwijkingen & 1 & 1.6 & - & 1 & 1.6 & \\
\hline pulmonale insufficiëntie & 3 & 5.0 & - & 3 & 5.0 & \\
\hline nierinsufficièntie & 2 & 3.3 & - & - & 2 & 3.3 \\
\hline onbekend & - & - & 1 & 1.6 & 1 & 1.6 \\
\hline rotaal & 51 & 85.0 & 9 & 15 & 60 & 100.0 \\
\hline
\end{tabular}

Pertioperatief oloedverlies. Vif pariënten $(8.4 \%)$ die radicaal werden behandeld werteden ten gevolge van oncorrigeerbaar perioperatief bloedverlies. Drie patienten overleden nog tijedens de operatie ten gevolge van de combinatie van ernstig bloedverlies en cardiale problemen. Eén paim riën overleed direut na beëindiging van de operarie ren gevolge van diffuse nabloeding en én overleed na 2 relaparotomieën wegens bloeding.

. Bij de nier-radicale behandeling overleden 3 pariênten wegens nier te stelpen bloeding ren gevolge van stollingsstoornissen. Bij één patiënn werd wegens stollingsstoornissen afgezien van de extra-anacomische reconstructie, én pariën overleed rijdeas het aanleggen van de extra-anatomische bypass en eén pariènt owerleed enkele uren post-operatief.

Inuffrcientie van de aortastomp. Negen wan de 114 radical behandelde parienten $17.9 \%)$ overleden alls gevolg van insufficientie van de aortastomp ("blow our") na cén tor honderdwanl" dagen. Als de ene blow out binnen én dag na operatie als nabloeding word beschouwd, dan blijkr een dodelijke blow our tijdens de ziekenhuisopname zich tussen én en vicr maanden na de operatie voor te doen.

Sepsis. Veertien van de radical behandelde parienten $(23.4 \%$ ) overleden aran een nier te beinwheden sepsis ten gevolge wan de prothese-infecric en 12 patienten overleden an de gewolgen wan sepsis na een of meerdere abdominale reoperaties wegens septische complicatics. Een parient overled seprisch ten gevolge van necrotiserende pancrearisis. Vau de niet-radical behandelde patienten overfeden er $4(30.0 \%)$ and en nier te beinvloden sepsis ten gevolge van de prorheseminfecrie.

Ischemie van de extremitaiten. Een patën overleed nadat revascularisatic misluke ten gevolge van riet te verhelpen recidiverende trombose wan de arteria subctavia en de extra-amatomische bypass beiderzijds. Een patiën waarbij revascularisatic pas én dag na protheseverwijdering plaats- 
vond, owerled, na vele ranimatiepogingen, aan hartrimestoornissen, mogelijk ten gevolge van de langdurige ischemie.

Neurologtsche afuijkingew. Een parien overleed ten gevolge van inklemming van de hersenstam na een bloedig cerebrovasculair accident.

Harfalen. De beide cardial overleden patienten in de radical behandelde groep hadden cen hartinfarce met astua cardiale en én nier-radicaal behandelde patiënt overleed op de negende post-operatieve dag aan een hartinfarcr.

Pulmonale insufficiëntio. In cotal overleden 3 parienten $(5.0 \%)$ an pulmonale complicares, allen in de radical bethandelde groep, ten gevolge van massale aspiratie, dubbelzijdige bronchopneumonie en een longabces.

Nievinufficiêntie. Bij é̉n partën werden de nierareriën nier gerevasculariseend. waarna werd geabstineerd wegens anurie in combinatie met ischemie wan én been. Bij een patiènt met chronische nierinsufficientie werd op verzock wan de patient zelf geabstineerd, nadar hij werd getroffen door en hartinfarct renwijl hij ook nog moeilijkheden had met de dialyse.

In figuur 4 worden de oorzaken van overlijden van alle patiëncen schemarisch wergegeven

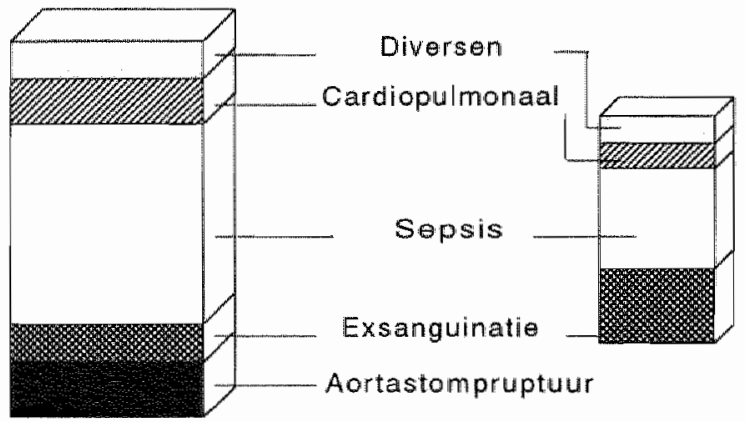

\section{Radicaal}

$$
n=50
$$

Niet-radicaal

$$
n=9
$$

Figum 4. Oomaken van de operatiemoraliteir

\subsubsection{LATE RESULTATEN}

\subsubsection{De late mortaliteit}

Na operatieve behandeling wan de infectie van de prothese werden 87 pariënten (59.6\%) warvan 64 radicaal en 23 nier-radical behandeld, uit het ziekenhuis 
ontslagen. Drie van de nier geopereerde patiënten gingen eveneens levend naar huis. Twee van deze nier geopereerde pariënnen overleefden resp $3.7 \mathrm{en} 0.6 \mathrm{jaar}$, de derde overleed spoedig na ontslag in een verpleegtehuis. $\operatorname{Van} 7$ patiënten zijn geen gegevens over het beloop na ontslag beschikbaar. De overige 80 patiënten, die operatief voor de infecrie van de abdominale vaatprothese werden behandeld, konden gemiddeld 2.7 jaar worden vervolgd met een maximum van 10.7 jaar. Tijdens deze periode overleden 36 patiënten na gemiddeld 1.9 jaar met een maximum van 10.4 jaar en een mediane overlevingsduur van 0.9 jaar.

De 43 overlevenden ( $27.9 \%$ ) leefden bij afsluiten van de follow up gemiddeld 3.5 jaar, mer een mediane overlevingsduur van 2.8 jaar en een maximum van 10.7 jaar. De cumulatieve overleving van alle patiënten volgens de life-table methode is weergegeven in figuur 5 .

De gemiddelde overlevingsduur van de overlevenden na radicale behandeling was 3.8 jaar en de mediane overlevingsduur 4.2 jaar. Na niet-radicale behandeling was de gemiddelde overlevingsduur 3.0 jaar en de mediane 1.8 jaar.

De cumulatieve overleving voor de radicale en de niet-radicale behandeling apart wordt weer gegeven in figuur 6. Ten aanzien van de cumulatieve lange termijn overleving waren er geen significante verschillen tussen radicale of niet-radicale behandeling of tussen vroege en de late infecties.

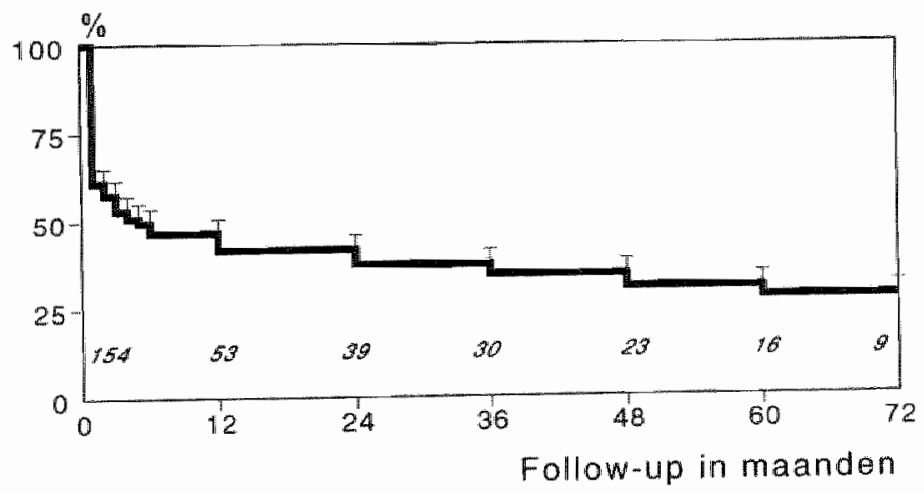

Figuur 5. De cumulaciewe averleving van de operatice behandelde patienten mer een abdominale prothese-infectie volgens de life table merhode 


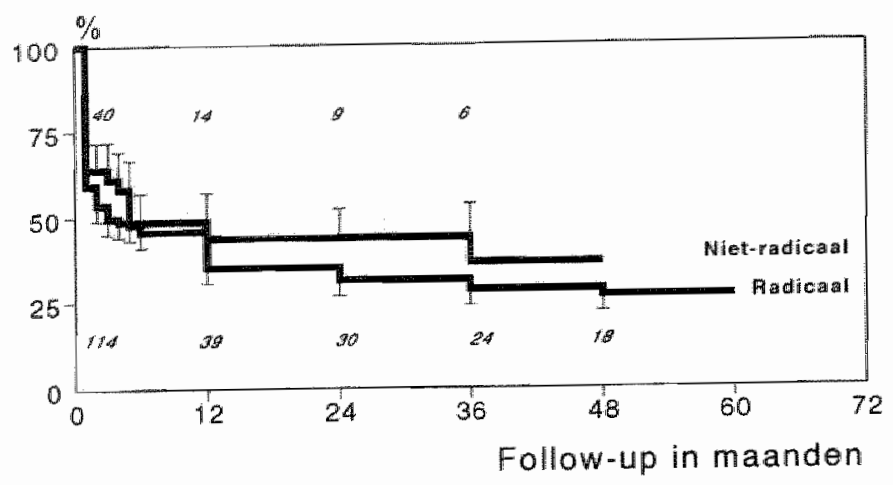

Figuur 6. Cumulateve postoperatieve overleving van de radical en de niet-radicaal behandelde parienten met cen abdominale prothese-infectic (cursief de aantallen "at risk')

\subsubsection{De late morbiditeit}

Van de 80 geopereerde en overlevende patiënten met follow-up gegevens konden de late complicaties worden geanalyseerd.

Late infecrie van de extra-anatomische bypass. Er ontstonden 13 lare infecries van de extra-anatomische bypass (10.7\%). Hoeveel van deze geinfecteerde extra-anatomische reconstructies waren geoccludeerd werd niet exact duidelijk.

$\mathrm{Na}$ radicale behandeling ontstond 11 keer een late infectie van de extra-anatomische bypass waaronder eenmaal een recidief.

De behandeling van deze 11 patiënten bestond uir: nieuwe exrra-anatomische bypass (1), vervangen wan het distale deel door vene (2) of prothese (1), verwijderen wan de bypass na progressieve afklemming (1), veneuze femoro-femorale cross over mer contralaterale amputatic (1), nieuwe arto-bifemorale prothese auta-bifemotale (3) en bij twee patiènten werd. een nieuwe aonto-bifurcarie prothese afgand wan de thoracale aorta aangelegd warvan de benen beiderziids door het foramen obruratorium werden gelcid.

Na niet-radicale behandeling ontstonden 2 late infecries van de extra-anatomische bypass.

Bij een pariën mer occlusic van de bypass werd een ampurarie door de knie verticht. De andere patiennt werd nier chirrurgisch behandeld: Hij overlked aan een cardiale oorzaak met een fistel in de lies.

De infecties van de extra anatomische bypass ontstonden gemiddeld 1.7 jaar na constructie, mer een mediane ontstaansperiode van 0.9 jaar. Elf van de 13 patiënten mer een late infectie van hun extra-anatomische bypass overleden tijdens de follow-up, van één patiënt konden geen vervolggegevens meer worden verkregen 
en één patiënt (waarbij de bypass progressief werd afgeklemd) overleefde zonder amputatie(s).

Late ischemie van de extremiteiten. De pariënten mer ischemie door afsluiting van de extra-anatomische bypass ten gevolge van infectie werden reeds onder de betreffende paragraaf vermeld (4.5.4.2) Vijfrien patiènten hadden, door progressie van het oblitererend vaatijden of ten gevolge van afshiring van de extra-anatomische bypass dusdanige ischemische klachten dat op grond daarvan een arteriële reconstrucrie werd werricht. Soms waren er meerdere operaties noodzakelijk.

De latste operatie wegens ischemie wór owerlijden of afslniten van de follow-up bestond uic: thrombectomie uit de extra-anatomische bypass of prothese die niet verwijdend of verrieuwd werd (7), iliacale PTA (1), iliacale verwijdingsplastiek (2), nieuwe bifuccacieprothese (1), bypass van aorta naar cross over (1) en thoracofemorale prothese (3), warvan écn unilatertal en én waarvan de benen door her foramen obeuratorium werden geleid. Er wonden 3 bovenbeensarnpuraties platats, 2 amputaties door de knie en een lare bilaterale bovenbeensamputatie.

Daarmee komt het totale vroege en late amputatiepercentage op $8.9 \%$ (zie rabel 4.54).

Late aortastompinsufficientie. Late insufficiëntie van de aortastomp of de naad kan zich uiten als ruptuur van de aortastomp of als een aneurysma van de aorta. Bij de 79 overlevenden werd een wan beide fenomenen $15 \mathrm{keer}$ wargenomen (18.9\%). Voor de radicale behandeling alleen bedragt dit percentage $23.8 \%$.

Een keer betrof her een aorta die na ontmanteling wan de end to side anastomose in zijn geheel was owerhecht. Vier patiënten kregen een ernstige bloeding uir de tractus digestivus als uiring: wan een recidief gastro-enterale fisted. Vier parienten overleden thuis of in bet ziekenhwis onder her beeld van een acure buik met hypovolemische shock, zonder dat een artasrompinsufficientie mer zekerheid kon worden angetoond. Een wan de pariënten overlefde ecn operatie wegens ruptun van een wals aneurysma wan de aortastomp na Ijaar en twee maanden, doch owerleed na een recidief 2 jaar en 11 maanden daana.

Cumxlatiene morbiditeit. De ernstigste, deels levensbedreigende, complicaties van de behandeling van infecties vam abdominale vatprothesen zijn insufficiencie wan de aortastomp, amputaties en ischemie van de extremiteiten ten gevolge van thrombose en/of infectie van de extra-anatomische bypass. Voor de 146 parienten die chirurgisch werden behandeld, warvan 114 radical en 32 niet-radicaal, en waarbij een totaal antal van 122 extra-anatomische bypasses werd angelegd, (waarvan 104 in de radicale groep en 18 in de niet-radicale groep) word de cumularieve morbiditeit weergegeven in tabel 4.57. Of en welke van de arteriele reconstructies in de follow-up periode werden vericht wegens thrombose van de exraanatomische bypass of wegens progressie van het obliterend vaadijden is niet met zekerheid bekend. 
Tabel 4.57 . Cumulatieve tate morbiditeir in procenten

\begin{tabular}{|c|c|c|c|}
\hline behandeling & amputaties & blow our & $\begin{array}{l}\text { infecrie } \\
\text { tab }\end{array}$ \\
\hline radical & 11.4 & 23.8 & 15.4 \\
\hline nier-radicaal & 3.1 & $\cdots$ & 16.7 \\
\hline rorad & 8.9 & 23.8 & 15.6 \\
\hline
\end{tabular}

Tabel 4.58 geeft cen frequentieverdeling van het totale aantal, vroege en late, van deze belangrijlste complicaties per patiënt. Omdat niet van alle patiënten alle gegevens compleet zijn gaat het om een minimum aantal en is her mogelijk dat er in werkelijkheid meer complicaties zijn opgetreden.

Tabel 4.58. Aancallen patiènen mer én of meer complicaties van vitale organen, de exrra-anatomische bypass, of ischemische, septische of bloedingscomplicaties.

\begin{tabular}{|c|c|c|c|c|c|c|}
\hline \multirow[t]{2}{*}{ anncal complicacies } & \multicolumn{2}{|c|}{ radicatal behandeld } & \multicolumn{2}{|c|}{ niet-radical behandeld } & \multicolumn{2}{|c|}{ totaal } \\
\hline & $n$ & $\%$ & $\mathrm{n}$ & $\%$ & $\mathrm{n}$ & $\%$ \\
\hline geen & 20 & 17.5 & 17 & 53.1 & 37 & 25.3 \\
\hline é̉n & 35 & 30.7 & 8 & 25.0 & 43 & 29.5 \\
\hline rwee & 43 & 37.7 & 4 & 12.5 & 47 & 32.2 \\
\hline crie & 11 & 9.6 & 2 & 6.3 & 13 & 8.9 \\
\hline vier & 5 & 4.4 & 1 & 3.1 & 6 & 4.1 \\
\hline total & 114 & 100.0 & 32 & 100.0 & 146 & 100.0 \\
\hline
\end{tabular}

In totaal werden 200 complicaties geregistreerd bij 109 patiënten. Van de $114 \mathrm{ra-}$ dicaal behandelde patiënten hadden er hoogstens 20 geen complicaties en van de 32 niet-radicaal behandelde pariènten bleven er maximaal 17 zonder complicaties. Dit verschil is significant ( $p<0.01)$. Van de radicaal behandelde patiënten hadden 94 patiënten (82.5\%) schade van én of meer vitale organen, de extra-anatomische bypass, of ischemische, septische of bloedingscomplicaties. Voor de niet-radicale behandeling was dat percentage $46.9 \%$. Het verschil in aantallen complicaties tussen radicale en niet-radicale behandeling is significant ten nadele van de radicaal behandelde patiënten. ( $<<0.001$, Mann-Whitney U test) 


\section{hoondostus \\ Discussie}

\subsection{REPRESENTATTVITEIT}

Bij de interpretatie van de resultaten uir deze studie rijst de vraag in hoeverre de behandelde patiënten uít deze studie representatief zijn voor de Nederlandse patiënten, waarbij een abdominale vaatprothese wordt geimplanteerd en of er verschillen bestaan tussen de in deze studie verzamelde gegevens en eerder in Nederland gepubliceerde gegevens over patiënten met een abdominale vaarprothese. Het aantal in Nederland gebruikte abdominale vaatprothesen is niet bekend en evenmin het aantal infecties daarvan. Vanwege de sterk wisselende en soms langdurige latentieperiode van een prochese-infectie, en het ontbreken van een centrale registratie, zijn geen gegevens over de werkelijke incidentie van infecties van abdominale vaatprothesen in Nederland beschikbaar.

In de huidige studie vond de primaire operatie plaats tussen 1972 en 1994 (mediaan 1985). De gemiddelde leeftijd van alle patiënten was 62.4 jaar. Van de pariënten die geopereerd werden wegens een aneurysma was de gemidclelde leeftijd 65.4 jaar en deze bedroeg 58.1 jaar voor de pariènten die een bifurcatieprothese kregen wegens obstruerend vaatlijden. De man: vrouw verhouding voor alle patiënten was $89: 1.1$. Bij de patiënten mer cen aneurysma was $2 \%$ vrouw en bij de pariënten mer oblitererend vaatlijden was $25 \%$ vrouw.

De gemiddelde leeftrijd van de patiënten die geopereerd werden wegens een aneurysma komt goed overeen met die van de patiënten uit de Nederlandse studie van Bosman ${ }^{28}$ waarin de resultaten worden beschreven van de vervanging van aneurysmata van de abdominale aorta door een bifurcaticprothese bij 647 patiënten, geopereerd tussen 1958 en 1978. Daarbij was de man vrouw verhouding 9: 1 en de gemiddelde leefiijd was 64.7 jaar voor de electief geopereerden en 68.8 jaar voor de acuut geopereerden.

De Nederlandse scudie van Van den Akker uit 1992 bevat de resultaten van 747 pariënten die tussen 1958 en 1980 een centrale vaatreconstrucrie ondergingen wegens obstruerend vaarlijden. Bij 518 patiënten met een man vrouw verdeling van 91:9 en een gemiddelde leeftijd van 55.7 jaar werd een prothese in het aorto-iliacale traject geimplanteerd. ${ }^{34 !}$ De patiënten uit de in dit proefschrift beschreven populatie die wegens obstruerend vattijden werden geopereerd zijn met gemid- 
deld 58.1 jaar iets ouder dan in de serie van Van den Akker en de man-vrouw verdeling toont mee $75: 25$ een grotere vertegenwoordiging van vrouwen.

Het aantal zickenhuisopnamen onder de hoofddiagnose aneurysma van de abdominale aorta steeg in Nederland tussen 1972 en 1992 van 433 naar 4002 per jaar, terwijl het percenrage patienten dat acuut moest worden geopereerd wegens ruptuur daalde van $39 \%$ naat $22 \%,{ }^{269}$ In de studie van Bosman (1958-1978) werd $36.4 \%$ van de patiënten met een aneurysma acuut geopereerd terwijl in onze studie (1972-1994) een percentage van $48.4 \%$ een acute primaire operatie onderging.

De leeftijd en de geslachtsverdeling wan her totale pariëntenmateriaal in onze serie komen dus redelijk overeen mer de gegevens hierover in eerder gepubliceerde Nederlandse studies over implantatie van abdominale vaatprothesen.

Het aantal acuut geopereerde patiènten ligt in onze serie duidelijk hoger dan thet gepubliceerde Nederlandse gemiddelde uit een vergelijkbare periode. Dit kan duiden op een mogelijk verhoogd infectie risico voor acuut geimplanteerde abdominale vaatprothesen.

De behandeling van geïnfecteerde abdominale vaatprothesen in Nederland kan alleen worden vergeleken mer literatuurgegevens. In Nederland wordt in $60.4 \%$ van de gevallen primair de radicale behandeling toegepast (zie tabel 4.33). In de literatutur over de radicale behandeling is dit percentage $73.3 \%$ en in totaal bestaat de behandeling in de literatuur in ingeveer de helft van de gevallen uit radicale protheseverwijdering. (zie tabel 2.4) In Nederland word primair in 34.4\% met de nier radicale behandeling begonnen, warna in tweevijfde van de gevallen alsnog wordt overgegaan op radicale behandeling, waardoor het totale percentage radicale behandelingen op 74\% uirkomt. De mogelijkheid dat niet- radicale behandeling vaker succes heeft gehad dan uir onze studie blijkr is niet uit te sluiten. De autologe en de in situ behandeling worden buiten Nederland in $20 \%$ en in Nederland vripwel nier roegepast. Ten aanzien van de gekozen behandeling is deze seric patiënten der halve niet zonder meer vergelijkbaar met de literatuurgegevens.

\subsection{DE PRIMAIRE OPERATIE}

Het ontstaan van een prothese-infectie is multicausaal ${ }^{267}$ en algemeen bestaat de, overigens onbewezen, opvatting dat contaminatie tijdens de operatie de belangrijksre oorzaak is ${ }^{29,23,324,362}$ In de literatuur worden frequent verschillende factoren vermeld die het ontstan van een infectie zouden bevorderen, variërend van algemene factoren die verband houden met de conditie van de patiënt, zoals ten tijde van de operarie bestaande ziekten, vootal op cardiopulmonaal gebied en diabetes mellitus, tot specifieke chirurgisch technische en infectieuze oorzaken zoals contaminatie vanuit de valtwand of de inhoud wan een aneurysma en wondinfecties. Daarnaast kunnen acute aneurysmachirurgie en multiple voorafgaande 
(vaat)operaties belangrijke voorwaardenscheppende omstandigheden zijn voor het ontstaan van infecties. 265,267 In deze studie zijn een aantal perioperatieve factoren geanalyseerd die deels ook in de liceratuur worden vermeld en die cen rol zonden kunnen spelen bij het ontstaan van de prothese-infectie. Deze factoren zijn te verdelen in reeds pre-operatief bestaande risicofactoren, in gebeurtenissen tijdens de operatie zelf en in postoperatieve complicaries, op de korte en op de lange termijn. Bij tenminste driekwart van de patiënten was één of meerdere van deze factoren, waarvan de helft van infectieuze aard, aanwijsbaar. (zie 4.2.2) Het 'gewicht' van ieder van deze factoren apart is niet te bepalen, maar identificatie van (combinaties van) sommige van deze factoren zou van nut kunnen zijn bij de preventie van protheseinfecties.

Over de problemen die zijn samen te vatten onder de titel 'hostile abdomen' komen sporadisch mededelingen voor maar geen systematische studies. ${ }^{220,250} \mathrm{Bij}$ $27.9 \%$. van de patiënten was een vroege reìnterventie (binnen 30 dagen) noodzakelijk, waarvan bij $20.1 \%$ wegens thrombose, ischemie of bloeding. (zie 4.2.2) Dit is bijna 2 maal zoveel als bij reconstructieve chirurgie wegens centrale vaatobstructies in Nederland wordt gemeld ${ }^{342}$ en het totale aantal patiënten met vroege reînterventies is met $27.9 \%$ meer dan 2 keer zo hoog als bij een gedeeltelijk contemporaine, gedeeltelijk oudere patiëntenserie met aneurysma chirurgie. ${ }^{28}$

Het aantal patiënten met wondinfecties $(11.0 \%)$, warvoor een vroege rënterventie noodzakelijk werd, is veel hoger dan verwacht zou worden in de categorie 'clean. wounds. (1.3\%) ${ }^{68}$ In de serie patiënten van Bosman die wegens een aneurysma werden geopereerd was het percentage wondinfecties voor de acuur geopereerden $8.3 \%$ en voor de electief geopereerden $4.2 \%{ }^{28}$ Szzilagyi (1986) kwam voor de reconstructieve chirurgie over een periode van 30 jaar ook op $4,2 \%$ wondinfecties. ${ }^{326}$ Friedman (1995) kwam in een prospectieve studie over 60 pariënten met obstructief vaatlijden wel op een wondinfectiefrequentie van $11.6 \%$ uit. ${ }^{109}$

Bij 19.6\% van de patiënten werd een postoperatieve sepsis (koorts met koude rillingen of koorts met positieve bloedkweek) vastgesteld. Over her vóórkomen van sepsis na chirurgie aan de abdominale aorta zijn geen cijfers bekend. Over de rol van sepsis en bacteriemie zijn de literatuurgegevens tegenstrijdig. Turnipseed suggereert op basis van het hoge aantal postoperatieve complicaties na primaire chirurgie in zijn serie patiënten met geïnfecteerde abdominale prothesen $(45 \%)$, dat prothese-infecries vaak voorkomen bij patiënten met wondinfecties en episoden van bacteriëmie na de primaire protheseimplantatie. ${ }^{339}$

Hoe vaak latere bacteriemie een infectie van de prothese veroorzaalkt bliff controversieel en directe bewijzen zijn er maar weinig. ${ }^{337}$ De infectiekansen bij hematogene uitzaaiing wan bacteriën zijn alleen bij proefdieren onderzocht, waarbij blijkt dat de infectiekans na intraveneuze toediening van bacteriën afneemt naarmate de pseudointima beter ontwikkeld is. ${ }^{203,217}$ Een pseudoincima wordt bij de mens maar zeer gebrekkig aangelegd. ${ }^{60,279,281,315}$ Het feit dar het verwijderen van de 
geinfecteerde prothese het aantal infecties van een daarvóór aangelegde extra-anaromische bypass niet doet toenemen ${ }^{267}$ dat invasieve monitoring her infectierisico niet verhoog ${ }^{264}$ en dat andere (tandheellkundige, urologische en endoscopische) ingrepen die bacteriemie kunnen veroorzaken het infectierisico nauwelijks verhogen ${ }^{337}$ doet vermoeden dat bacteriëmie alléén, geen belangrijke oorzakelijke factor is voor het ontstaan van prothese-infecties.

Postoperatieve urineweginfecties komen na centrale vaatchirurgie voor in een frequentic van 14\% tot $17 \%, 28,20 \%$ Wij vonden deze complicarie bij $29.7 \%$ van de patiënten. Luchrweginfecties komen normaal voor in een frequentie van $16 \%$ tot $25.9 \%{ }^{28.209}$ In onze serie werden luchtweginfecties in $24.7 \%$ geregistreerd.

Er zijn geen gegevens die erop duiden dar luchrweg- en urineweginfecties bij de pathogenese van prothese-infecties een belangrijke rol spelen. ${ }^{337}$ Lorentzen vermeldde wel dat op de prorhese hetzelfde micro-organisme werd gevonden als in de urine. Voor de luchrweginfecties vond hij geen relatie. ${ }^{197}$ Van Baalen (1996) beschreef een prothese-infecrie die mogelijk een relatie had met een postoperatieve pneumonie, ${ }^{343}$

Er is dus geen relatie tussen urine- en luchrweginfecties enerzijds en prothese-infecties anderzijds bekend en ook onze studie geeft hiervoor geen indicatie. Wel is bekend dat meer dan $60 \%$ van de wondinfecries gepaard gaan met andere infecties en dat dit in $30 \%$ een urineweginfectie en in $25 \%$ een luchrweginfectie betreft. ${ }^{88}$ In $28.6 \%$ van de patiënten uir onze serie waarbij dit gegeven achterhaald kon worden waren er bij de primaire operatie bacteriën in het aneurysma aantoonbaar. In de literatuur varieert dit percentage tussen $5 \%{ }^{147}$ en $37 \% .{ }^{99}$ Een relatie van deze bevinding met het ontstaan van infecties is daarmee op grond van onze gegevens dus ook niet aantoonbaar.

\subsection{HET INTERVAL}

In het hier beschreven patiëntenmateriaal werden na de primaire operatie in een periode van gemiddeld 3.7 jaar bij 47 patiënten $(30.5 \%) 92$ arteriële reinterventies verricht (1.96 operaties per patiënt). Zowel de peri-operatieve vroege reüntervenvies (bij 17.5\% van de patiënten) als de late reinterventies (bij $20.1 \%$ van de pariënten cussen én en 128 maanden na de operatie) is veel hoger dan het aantal reoperaties voor oblitererend en dilaterend vaatijden in andere Nederlandse series $^{28,342}$ Deze bevinding steunt de hypothese dat re-operatie een risicofactor voor infectie vormt. (zie 2.4 .4 en 4.2.2)

Analyse van de lare septische reinnterventies die bij $42.2 \%$ van de patiënten noodzakelijk waren doet vermoeden dar de 65 'abcessen en fistels', gevolg zijn van de prothese-infecrie. Dir geldr zeker voor de liesabcessen en liesfistells, de aorto-enterale en de aorto-ureterale fistels en de embolische abcessen die in de interval periode werden behandeld. De patiënten met intra-abdominale- en retroperitoneale ab- 
cessen hadden die tweemaal (van de elf keer) op basis van een diverticulitis van het sigmoid. Bij deze twee patiënten kan de prothese secundair geìnfecteerd zijn. Bij de andere patiènten waren er geen aanwijzingen voor andere intra-of retroperitoneale parhologie dan de protheseinfecrie zelf.

Het interval tussen de eerste reinterventie wegens abces of open wond in de lies en de definitieve behandeling van de prothese-infectie was bij de betreffende 65 patiënten gemiddeld 7.6 maanden; 1.9 maanden voor de patiënten die radicaal werden behandeld en 34.5 maanden voor de patiënten die secundair radicaal werden behandeld. Dat betekent een gemiddeld uirstel van de definitieve behandeling van 2.7 jaar door mislukte niet-radicale behandeling bij het bestaan van een abces of open wond in de lies.

Naadaneurysma's, die zowel het gevolg kunnen zijn van prothese-infecrie alsook oorzak ten gevolge van re-operatie daarvoor, werden in deze serie patiënten die uiteindelijk een prothese-infecrie bleken te hebben, gevonden in $38.3 \%$. Dir percentage is meer dan het dubbele van het aantal dat werd gevonden door van den Akker en bijna 10\% meer dan door Sieswerda met meer geavanceerd onderzoek werd vastgesteld. ${ }^{300,341}$ In het interval werden bij 26 patiënten (16.9\%) 34 naadaneurysma's behandeld, waarvan 5 wegens ruptuur. Bij de geruptureerde naadaneurysma's in de lies werd vanaf het begin rekening gehouden mer her bestaan van een infecrie, bij 2 anderen werd resp. een veneus interponatat aangebracht en cen prothesebeen verwijderd. Bij 7 van de 26 patiënten $(26.9 \%)$ waren er dus kennelijk redenen om an een infectie te denken. Bij de patiënt met duodenumletsel bij de operatieve behandeling van het naadaneurysma werd de infecrie mogelijk daardoor veroorzaakt.

Littekenbreuken, die na de primaire operatie bij $5.2 \%$ ontstonden, worden voor een belangrijk deel door wondinfecrie veroorzaakt en komen voor na gemiddeld $10 \%$ van alle laparotomièn en na aneurysmachirurgie in $4-8 \%{ }^{28,92.172}$ Deze wondgenezingsstoomis is dus waarschijnlijk niet van belang geweest bij het ontstaan van infecties van de prothese.

Infecticuze ziekren van, en operaties aan de tractus digestivus (in onze serie patiënten in $12.3 \%$ ) en de tractus urogenitalis (bij onze patiënten $8.4 \%$ ) kunnen, naast het feit dat zij bacteriemie kunnen veroorzaken, een infectie van de prothese opleveren door hun anatomische positie ten opzichte van de prothese. Secundaire infectie per continuitatem kan de oorzaak zijn geweest bij de patiënten warbij tijdens de darmresectie de prothese a vue kwam (2), bij de patiënt mer een appendiculair abces en de pariënten mer diverticulitis. lschemische colitis na centrale arteriele reconstructies, waarvoor hetzelfde geldt, heeft een gerapporteerde incidentie van 1-2.8\%20,24,66 en komt in onze serie (1.3\%) dus niet meer voor dan normaal. $20,24,162$ Uretercomplicaties vonden wij in onze serie bij $7.8 \%$ van de patiënten. Postoperatieve uretercomplicaties na abdominale vaatchirurgie komen voor in $1.3 \%$ en gaan significant vaker ( $\cot 55 \%$ ) samen met vasculaire complica- 
ties van de prothese dan bij pariënten zonder uretercomplicaties. Re-operatie voor deze complicatie heeft een mortaliteit van $21 \%$ die vrijwel geheel is toe te schrijven aan de vasculaire verwikkelingen, waarvan tweederde bestaat uit infecties van de prothese. 36.3

De lange duur van het interval en het grote aantal operaties in deze periode leidt tot de vraag of gebeurrenissen in het interval gevolg of oorzaak zijn van protheseinfectie.

Het diverticulair en het appendiculair abces zijn waarschijnlijk niet te voorkomen oorzaken geweest voor het ontstaan van de infectie. Ischemische colitis (1), de uretercomplicaties (12) en darmletsels (2) waren mogelijk well te voorkomen oorzaken bij 15 pariënten $(9.7 \%$ ) Het aantal vasculaire reïnterventies (bij $30.5 \%$ van de patiënten) speelt waarschijnlijk een rol bij het ontstaan van de prothese-infecties. De lange periode tussen de eerste reïnterventie wegens abces of open wond in de lies en de definitieve behandeling van de prothese-infectie doet vermoeden dat nadat verdenking was gerezen niet alles in het werk werd gesteld om de diagnose te bevestigen.

\subsection{DE INFECTIE}

\subsubsection{HET TIJOSTUP VAN MANIFESTATIE VAN DE INFECTIE}

In de literatuur wordt, meestal zonder onderscheid te maken tussen abdominale of perifere prothesen, op basis van incidentie, klinische presentatie of het oorzakelijke micro-organisme onderscheid gemaakt tussen vroege en late infecties. (zie 2.5.1) In de meer recente literatuur wordt een grens gelegd bij 30 dagen ${ }^{10}$ of bij 3.5 manden. ${ }^{131}$ Als op basis van de incidentie een scheidslijn wordt aangebracht bij 4 maanden dan blijkt $37.7 \%$ van de infecries zich binnen deze periode voor te doen en $62.3 \%$ daarna.

Een infecrie van de abdominale prothese in de vorm van AEF bleek significant later op te treden dan een PGI $(p<0.01)$ en klinische presentatie mer aspecifieke symptomatologie bleek significant meer voor te komen bij vroege infecties. $(p<0.01)$ De hospitaalmortaliteit was bij de vroege infecties significant hoger dan bij de latar oprredende infecries. ( $p<0.001$ ) (zie 4.3.1 en 4.5.3.7)

Ten aan zien wan de resultaten van microbiologisch onderzoek bleken er geen sigthificante verschillen tussen de vroege en de late infecties. (zie 4.4.9)

\subsubsection{PRESENTATIE VAN DE INFECTIE}

Lorentzen vond uitsluitend infecties bij in de lies geanastomoseerde prothesen. ${ }^{197}$ Reilly vermeldr dat de 'vast majority' zich presenteert met tekenen van infectie in 
de lies. ${ }^{265}$ In onze studie presenteert $33.1 \%$ van de patuënten zich met liessymptomatologie. Klinische presentatie met aspecifieke symptomarologie blijkr in onze studie significant meer voor te komen, voornamelijk bij vroege infecties. Presentatie met liesproblemen of bloeding uit de tractus digesrivus blijkt significant meer bij de laar optredende infecties voor te komen en presentarie mer een naadaneurysma of een sinus blijkt uirsluitend bij de late infecties voor te komen.

Terwijl de verhouding tussen het aantal PGI's en AEF"s bij de patiènten uit her literatuuroverzicht ( $42 \% \mathrm{AEF})$ en onze studie ( $40 \% \mathrm{AEF}$ ) nauwelijks verschilt, presenteren zich in onze studie minder patiënten met liessymptomarologie. Dit verschil kan alleen worden verklaard als er aanzienlijke verschillen bestaan tussen de geopereerde Nederlandse patiënten en de in de lireratuur beschreven patiëntenseries.

Tabel 5.1. De locatie van de distale anastomose in 41 publicaties uir het literatuutoverticht (9.3) warbij dit gegeven werd verneld.

\begin{tabular}{lcccc}
\hline & literatur & $\%$ & deze studie & $\%$ \\
\hline buisprothese & 38 & 5.1 & 21 & 13.7 \\
aorto-bi-iliacaal & 136 & 18.4 & 67 & 43.8 \\
aorrofemoraal & 565 & 76.5 & 66 & 42.5 \\
totaal & 739 & 100.0 & 154 & 100.0 \\
\hline
\end{tabular}

Vergelijking met de literatuur leert dat er met name aanzienlijke verschillen bestaan in het aantal prothesen dat in de lies wordt geanastomoseerd (tabel 5.1). In de reeds genoemde Nederlandse studies werd bij patiënten met een aneurysma in $6 \%$ en bij patiënten die wegens oblitererend vaarlijden werden geopereerd in $14.1 \%$ één of beide anastomosen in de lies aangelegd. ${ }^{28,342}$ In twee andere, eveneens Nederlandse studies, één over valse aneurysma's na reconstructies wegens obstructief vaatlijden bleek $30.1 \%$ van de bifurcatieprothesen in een of beide liezen geanastomoseerd, en de andere over aorto-enterale fistels wordr $10 \%$ fernorale anastomosen bij 2550 abdominale reconstructies in 30 jaar opgegeven. ${ }^{3.4 .343}$ In onze studie was in $86.3 \%$ van de geïnfecteerde prothesen als bifurcarieprothese ingebracht en was de distale anastomose in $13.1 \%$ ann de ene kanr in de lies en aan de andere kant iliacaal gelokaliseerd en bij $29.4 \%$ beiderzijds in de lies. In $42.5 \%$ van de patiënten uit onze serie was er dus sprake van tenminste één anastomose in de lies. In Amerikaanse en andere Europese studies, opgesomd in het literatuuroverzicht, blijkt dat in $76.8 \%$ aorto-(bi)femorale prorhesen werden geimplanteerd.

Het aantal pariènten met een femorale anastomose is in onze studie dus hoger dan in andere Nederlandse series, maar aanzienlijk lager dan in Amerikaanse of andere Europese series. 
Het aantal prothesen dat distaal in de liezen eindigt is dus in de literatuur ruim 2.5 keer hoger dan in onze Nederlandse serie. De veel geciteerde stelling dar anastomosering in de lies het infecrierisico vergroot (zie 2.4.3), is met behulp wan onze gegevens echter nier te bewijzen omdat wij de ware incidentie in Nederland niet kennen.

\subsubsection{DHANOSTEK}

Van de gebruikte diagnostische methoden was zowel de toepassing als de opbrengst sterk wisselend (fig 2). Er bestaat geen Nederlandse richtlijn voor de diagnostiek en behandeling van infecties van een abdominale vaatprothese.

De toepassing van meerdere methoden per patiënt kan erop duiden dat bij de patiënten met aspecifieke symptomen of bloedingen eerst naar andere oorzaken worde gezocht en dat niet altijd even duidelijk is met welke diagnostische methode(n) zekerheid te krijgen is.

Hoewel wordt aangegeven dat de diagnostiek voor een groot deel op de klinische bevindingen berust, ${ }^{267}$ werden in totaal maar $20.8 \%$ van de patiënten in onze serie zonder aanvullende diagnostiek behandeld en werd bij $79.2 \%$ één of meer van de genoende diagnostische hulpmiddelen ingezet. Bij de patiënten die zich presenteerden met liessymptomatologie in de vorm van een abces of een sinus werd in $72.5 \%$ aanvullende diagnostiek gedaan, dic in $65 \%$ bevindingen bewijzend voor de diagnose opleverde. Hoewel in Nederland in vergelijking met de literatuur (zie 5.4.2), minder anastomosen in de lies worden geconstrueerd, en dus meer infecties zich volledig intra-abdominaal bevinden, en derhalve meer diagnostische hulpmiddelen moeten worden gebruikt, kan de vraag worden gesteld of bij evidente afwijkingen in de lies overbodige diagnostiek werd verricht en waarom.

Van de 43 patiênten met een bloeding uit de tractus digestivus werden er 30 $(69.8 \%)$ nog op dezelfde dag geopereerd, waarvan $5(18.6 \%)$ zonder een vorm van aanvullende diagnostick. Dat betekent dat minstens 5 van de 30 patiënten (16.6\%) mer AEF circulatoir zo instabiel waren dat operatie nier kon worden uitgesteld.

De beste diagnostische resultaten werden in ons pariëntenmateriaal verkregen met sinografie $(94.5 \%$ positief), gevolgd door isotopenscintigrafie (68\% positief) en computertomografie (bij $55 \%$ vochr, pus of gas rond de prothese). Daarnaast werd bij CT in 10\% bovendien een infiltraat rondom de prothese gevonden en in $13.8 \%$ een intra of retroperitoneaal abces. Inclusief de ureterlekkage en de naadaneurysma's leverde $\mathrm{CT}$ in $75.4 \%$ het bewijs of sterke aanwijzingen voor het bestaan van een infectie. Of met MRI in de toekomst nog betere resultaten kunnen worden bereikt dan mer CT, moer nog worden afgewacht.

Isotopenscintigrafie met Indium ${ }^{111}$, die bij slechts 22 patiënten werd verricht $(14.3 \%)$ was bij $68 \%$ posirief. In andere klinische studies werden percentages van 
79-90\% bereikt. ${ }^{16,365}$ Wellicht is de geringe ervaring deber an de lagere opbrengst in onze serie.

Naaldaspiratie en kweek wan de vloeistof rondom de prothese levert in de literatuur groei van micro-organismen op in 13\% van alle prothesen dic na verwijdering een positieve kweek opleveren. ${ }^{136.181}$ Echo- of CT-geleide naaldaspiratie van het vocht rondom de prothese werd in deze studie 26 keer werricht $(16.9 \%)$ en leverde bij kweek van het aspiraat 16 keer $(61.5 \%)$ groei wan micro-organismen op. Voor de hele serie betekent naaldaspiratie cen voor infecrie bewijzende methode in $10.4 \%$.

Mede op grond van de gegevens uit de literatuur kan bij her vermoeden van cen abdominale prothese-infectie, uitgaande van de 3 presentatievormen, een richtlijn voor de diagnostiek worden opgesteld: volgens her schema in figuur 7.

Nadere diagnostiek is overbodig indien de prothese in de lies in een abces ligt of in de wond zichtbaar ('local evidence of infection") is. Bij bestaan van een sinus in de lies kan sinografie leren of er een verbinding mer de prothese bestaat. Als de prothese dan met contrast wordt omspoeld betekent het dat de prorhese los ligt en er een infectie bestaat. Als geen verbinding zichtbaar wordt is infectie niet uitgesloren en moet de weg van de aspecifieke symptomatologie worden gevolgd. Een abces kan een probleem vormen in die zin dat de uitbreiding in de diepre niet bekend is en een te rigoreus débridement zelf een infectie van de prothese kan veroorzaken. Echografie of CT vóór drainage kan laten zien of de prothese door vloeistof omgeven is. Zo ja, dan is er sprake van een prothese-infectie, die adequatat moet worden behandeld, zo nee, dan kan alleen abcesdrainage volgen.

As er een naadaneurysma bestaat kunnen lokale of systemische verschijnselen wijzen op een infectie. In dat geval kan de lijn van de aspecifieke symptomatologie worden gevolgd. Indien pas bij operatie blijkt dat er mogelijk een infectie bestaat verandert de operatie in een exploratie mer afnemen van kweken en beoordeling van de ingroei. Indien pas na operatie tekenen van infectie ontstaan moer de lijn van de lokale verschijnselen worden gevolgd.

Bij aspecifieke symptomatologie ('systemic evidence of infection') is niet zelden al CT verricht om andere oorzaken voor een septisch ziektebeeld op te sporen. Als CT (of MRI) geen uitsluitsel geeft is Indium "1" leucocytenscintigrafie de volgende stap. Indien ook deze zonder afwijking is blijven er 2 mogelijkheden: Afhankelijk van de waarschijnlijkheid van een infectie (klinisch beeld) kan worden afgewacht en het onderzoek worden herhaald of kan bij sterke verdenking, een chirurgische exploratie worden verricht.

Bij een bloeding uit de tractus digestivus zijn er 2 mogelijkheden. Bij de circulatoir stabiele patient moet (ook om andere pathologie uir te sluiten) een gastro- en/of colonoscopie worden verricht. Als de prothese in het lumen van de darm zichubar is, is het bestaan van een aorto-enterale fistel met infectie bewezen. Indien de pro- 


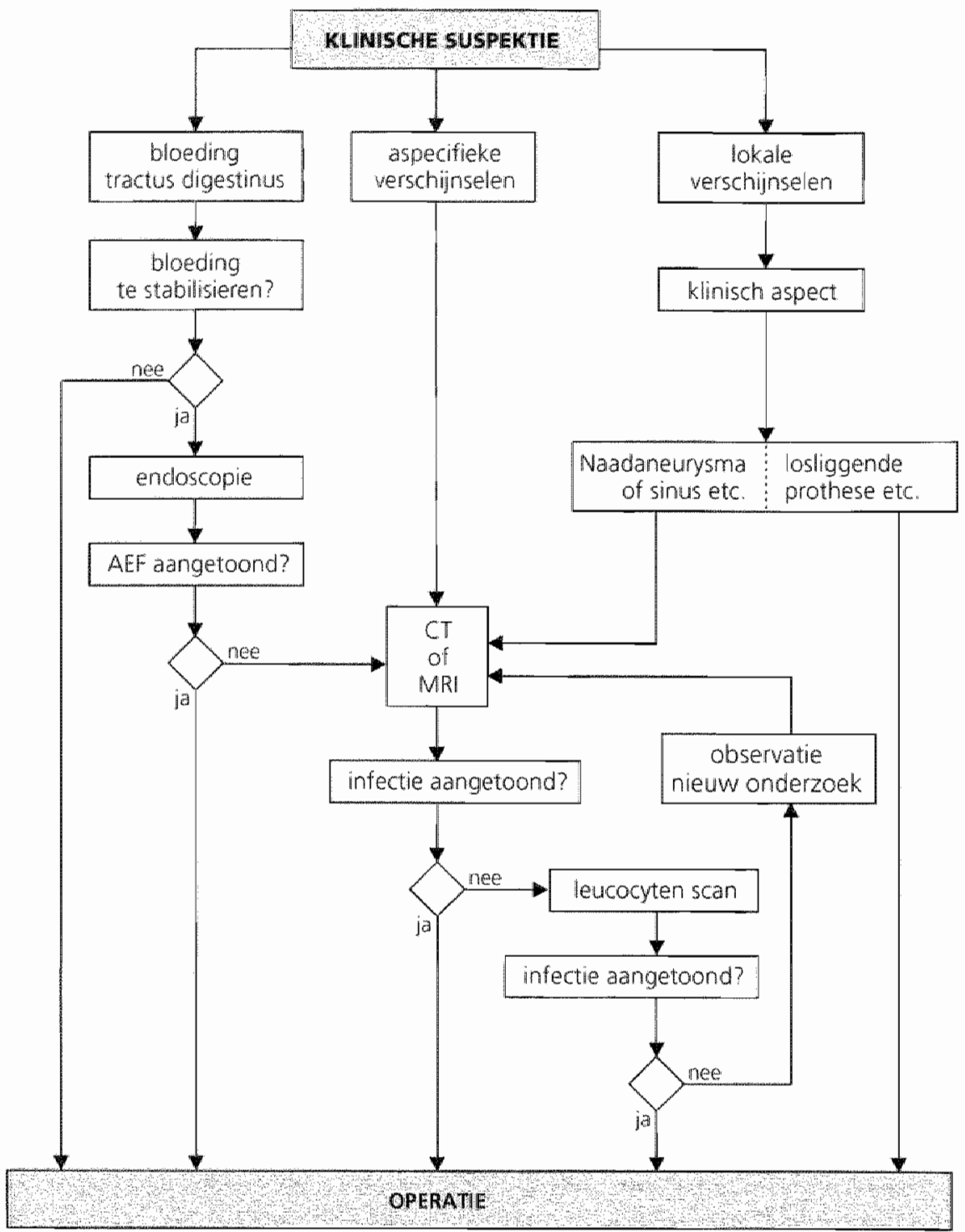

Fuguur 7. Schema diagnosrick

these niet zichtbaar is (de meerderheid) moet, eventueel in versneld tempo, het programma van de aspecifieke sympromatologie worden gevolgd. 
Bij de circulatoir instabiele patiënt zijn er eveneens 2 mogelijkheden. Als scabilisatrie lukt kan her bovenstaande programma worden gevolgd. Als stabilisatie niet lukt dient onmiddellijk operatie plaats te vinden door een team dar ook in staat is de prothese-infectie te behandelen. Indien mogelijk kan op de operatiekamer nog een scopie worden verricht.

Indien niet radicale behandeling wordt overwogen, is het van belang te weten hoever de infectie zich langs de prothese heeft uirgebreid. De mogelijkheden darvoor zijn: CT (of MRD) en leucocytenscintigrafie of operatieve exploratie. Vocht en/of gas rondom de prothese, of een positieve scan van de rest wan de prochese geeft zekerheid over het deel dat tenminste geinfecteerd is. Her geeft gén zekerheid dat cen ander deel van de prothese nier bij de infectie is betrokken

\subsubsection{BEHANDELING}

Bij het literatuuronderzoek werden vier vormen van behandeling onderscheiden (2.7) gebaseerd op het al dan nier radicaal verwijderen van de prothese en op de wijze van revascularisatie (geen revascularisatie, extra-anaromische revascularisatie, revascularisatie met autoloog materiaal of in situ revascularisatie). In het hier beschreven patiëntenmateriaal werden slechrs 3 patiënren 'in situ' behandeld. Autologe revascularisatie werd bij 4 patiënten toegepast na radicale protheseverwijdering. Daarom werd de in deze studie beschreven patiëntengroep onderverdeeld naar twee hoofdvormen van behandeling: de radicale behandeling (114 patiënten), en de niet-radicale behandeling ( 32 patiènten). Daarnaast werd bij 8 patiënren geabstineerd.

Ten aanzien van de keuze voor radicale of niet-radicale behandeling bleek er geen. sarnenhang te bestaan met het feit of het om een vroeg dan well lat optredende infectie ging. Bij 4 patiënten vond na radicale protheseverwijdering geen revascularisatie plaats (3.5\%) Van de 804 radicaal behandelde patiënten uit het literacuuroverzicht werden er 103 niet gerevasculariseerd. (12.8\%)

Tabel 5.2 toont een overzicht van de toepassing van de vier hoofdvormen van behandeling zoals dat naar voren komt uit het literatuuroverzicht en de eigen pariëntenserie. Hieruit blijkt dat in het Nederlands patiëntenmateriaal, in overeenstemming met de gegevens uit de literatuur, de radicale behandeling op de eerste plaats komt en ook dat relatief veel patiënten radicaal worden behandeld. De andere vormen van behandeling spelen bij de pariënten in deze studie een veel minde belangrijke rol.

Bij de hier gepresenteerde pariëntenserie werd bij $39.6 \%$ der patiênten aanvankelijk geen radicale behandeling verricht. Eenderde van hen (21 van de 61) moest later alsnog radicaal behandeld worden. Van de patiënten waarbij de infectie zich in de lies manifesteerde werd $51.0 \%$ in eerste instantie niet-radicaal behandeld en van de AEF patiënten $41.2 \%$. 
Tabel 5.2. Vergelijking van de behandeling in de eigen patentenserie mer die van her literaturovericht $(9.3)$

\begin{tabular}{|c|c|c|c|c|}
\hline & aantal & 0 & literatum & $\%$ \\
\hline radical & 108 & 70.1 & 804 & 49.7 \\
\hline antoloog & 4 & 2.6 & 106 & 6.5 \\
\hline nier-tadical & 32 & 20.8 & 283 & 17.5 \\
\hline in siuu & 2 & 1.3 & 220 & 13.6 \\
\hline onbekend" & . & - & 155 & 9.6 \\
\hline geen beh & 8 & 5.2 & 51 & 3.1 \\
\hline rotanl & 154 & 100.0 & 1619 & 100.0 \\
\hline
\end{tabular}

In alle publicaties blijkt zonder uitzondering, selectie van patiënten ten aanzien van de gekozen behandeling te hebben plaats gevonden. (zie 2.7.2)

Selecriecriteria waren in onze serie niet te achterhalen. Dat er echter sprake moet zijn geweest van een vorm van selectie blijkt uit het feit dat in dit materiaal uit verschillende ziekenhuizen her percentage aanvankelijk niet-radicaal behandelde patiënten per deelnemend centrum varieerde tussen $3.7 \%$ en $57.1 \%$. Zowel presentatie met een infecrie in de lies, als presentatie in de vorm van een aorro-enterale fistel blijken waak aanleiding te geven tor niet-radicale behandeling.

Algemeen wordt aangegeven dac de radicale methode de enige universeel toepasbare en ook de meest toegepaste methode is, die ook nog mogelijk is als andere methode(n) niet het beoogde resultaar hebben opgeleverd. ${ }^{88,126,136,197}$

\subsubsection{VROEGE RESULTATEN}

Operatiemortaliteit. De operatiemortaliteit van de in deze thesis beschreven pavënten, $45.8 \%$ voor de radicale behandeling van $A E F$ en $42.4 \%$ woor de radicale behandeling van PGI, wertoont een groot verschil met de beste Amerikaanse series madr minder verschil met gemiddelden uir de literatuur (appendix 9.3) Een verzameloverzicht uit 1992 mer voornamelijk Amerikaanse cijfers levert voor de behandeling van de AEF een operatiemortaliteit op van $46 \%$ en voor $\mathrm{PGI}$ van $21 \% .36 \%$ De beste gepubliceerde resultaten zijn een operatiemortaliteit van $16 \%$ voor een gemengde serie ${ }^{267}$ en $18.2 \%$ voor een serie mer uirsluitend AEF. ${ }^{178}$ In deze beide series werd echter een forse selectie toegepast, door onder meer uirsluirend de morvaliteit ren gevolge van techtstreeks aan de infectic gerelateerde doodsoorzaken tot de operatiemortaliteit te rekenen. Mer dezelfde definitie van operatiemortaliteit, zouden in de hier beschreven serie, alleen de patiënten met de de ceerste 3 doodsoorzaken uit tabel 4.53 met verbloeding en sepsis tot de perioperatieve mortaliteit worden gerekend, waardoor de operatiemortaliteit voor de radicale behandeling op $24.6 \%$ en woor de niet-radicale behandeling op $21.9 \%$ zou uitkomen, met een 
torale ziekenhuismortaliteit wan $23.9 \%$, hetgeen het gemiddelde in de liseratur benadert. Omdat de aantallen voor niet-radicale behandeling $(6$ mer slechrs 1 niet-radicaal behandelde PGI) ce klein worden kan geen zinvolle statiscische analyse op deze getallen worden tirgevoerd.

De mortaliteitscijfers van de radicale behandeling van de PGI bij de door ons be-studeerde serie pariènten liggen globaal $10 \%$ hoger dan het gemiddelde in de literatuur en voor de radicale behandeling van de AEF ongeveer even hoog. De nietradicale behandeling van de PGI levert een zelfde mortaliteit op als in de literatuur wordt aangegeven. De resultaren van de niet-radicale behandeling van de AEF zijn zelfs niet globaal te vergelijken. (zie tabel 5.3)

De autologe en de 'in situ' behandeling werden zo weinig gepraktiseerd, dat daarover geen uitspraken zijn te doen. De resultaten van deze zeer selecte groepen patiënten met een operatiemortaliteit in de literatuur van resp $11.6 \%$ en $8.0 \%$, kunnen niet worden vergeleken met de resultaten van de radicale behandeling warbij veel minder selectie voorkomt.

Tabel 5.3. Operatiemortaliteir per type infecrie en per type behand ing vergeleken mer gemiddelden uir de literatutur van het lireraturoverzicht. (appendix 9.3)

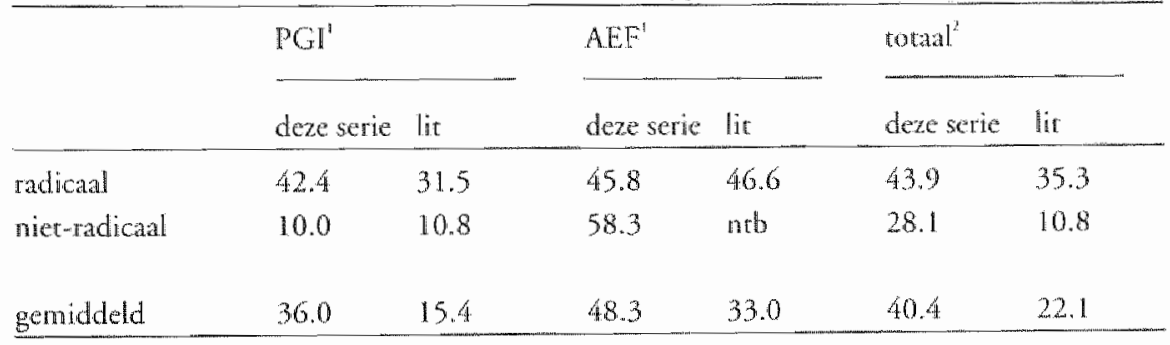

"De series in de literaturur met uitsluitend PGI of AEF;" Alle series bevatrende PGI en AEF nb: nier te berkenen

Doodsoorzaken. De belangrijkste doodsoorzaak in de postoperatieve periode in de hier geanalyseerde patièntenreeks, sepsis ten gevolge van persisteren van rerroperitoneale en abdominale infectie met multiple organ failure, is met $51.6 \%$ niet anders dan in de literatuur wordt vermeld. ${ }^{236.267}$

Bloeding komt met $13.5 \%$ op de rweede plaats en cardiale, renale, neurologische problematiek is verantwoordelijk voor her resterende deel. Dit kom overeen mer literatuurgegevens. (zie 2.8.2.1)

Operatiemorbiditeit. Zoals te verwachten bleek de behandeling van infecries van een abdominale varprothese een aanzienlijlke morbiditeit van de vitale organen met zich te brenger. Het optreden van zowel abdominale als systemische sepsis bleek significant meer voor te komen na radicale behandeling. Dit bevestigt de gedachte dat de voor de radicale behandeling benodigde grote operatie of de dun van de ischemie verantwoordelijk zijn voor de complicaties en daarmee voor een 
groor deel de uitkomst bepalen. De geringe aantallen patiënten die segentieel of gestadieerd werden behandeld maken ren aanzien van dit aspect geen statistisch onderbouwde conclusies mogelijk.

\subsection{LATE RESULTATEN}

Persisteren van de infectie en progressie van het perifeer oblitererend vaarlijden in onze patiëntenserie, vormen naast cardiopulmonale insufficiëntie en maligniteiten, belangrijke oorzaken voor de mortaliteit op lange termijn.

Lave moraliteit. $\mathrm{Na}$ implantatie van een abdominale vaatprorhese is de vijfjarsoverleving $59 \%$ tor $67 \%$ en de tienjaarsoverleving 30 tor $33 \%$ en is er een mediane overlevingsduur van omstreeks 8 jaar, warbij cardiale afwijkingen de belangrijkste uiteindelijke ( $>60 \%$ ) doodsoorzaak vormen. ${ }^{28.300 .326}$

De overleving na de primaire operatie van de hier bestudeerde patiënten waarbij zich na de implantatie van de abdominale vaatprothese een infectie van de prothese manifesteert is gemiddeld 5.3 jaar (standaard deviatie 5.2 jaar). De mediane overlevingscluur is 4.1 jaar. Dit betekent dat de resterende levensverwachting ten opzichte van de patiënten die géén infectie krijgen, met de helft wordt verkort als er een infectie van de abdominale vaatprothese optreedt.

De cumulatieve overleving voor het totaal van de hier beschreven 154 patienten na behandeling van de prothese-infecrie is $39.3 \%$ na 1 jaar, $32.0 \%$ na 3 jaar en $27.9 \%$ na 5 jaar. Voor de radicale behandeling bedraagr de overleving na één jaar 35.4\%, en de drie- en vijfjars owerleving resp $28.8 \%$ en $16.9 \%$. Nier behandelen of nietradicale behandeling levert cen overleving op van $43.9 \%$ na één jaar en $36.6 \%$ na drie jaar. Na 5 jaar resteert nog maar één patiënt. Na radicale behandeling is de mediane overlevingsduur 4.2 jaar en na niet-radicale behandeling is deze 1.8 jaar. Hoewell de overleving bij niet-radicale behandeling aanvankelijk dus beter lijkt is deze op termijn lager dan na radicale behandeling.

Deze tesultaten zijn aanzienlijk minder dan in de literaruur worde vermeld. Yeager (1992) komt op grond van geselecteerde, uitsluitend Amerikaanse, gegevens over de radicale behandeling tot een cumulatieve overleving van $60 \%$ na én jaar en $50 \%$ na 5 jaar. ${ }^{367}$

Dit kan betekenen dat er in onze serie meer patiënten niet van hun infectie genezen waren of dat hun conditie al vóór de behandeling, door welke oorzaak dan ook, al slechter was, of dat er minder selecrief to behandeling werd besloten ook in relatief desperate gevallen.

Late morbiditeit. Als de infectie nier gecureerd is kan zich dat manifesteren in de vorm van insufficiëntie van de aortastomp of als infectie van de (nieuwe) prothese, de autologe reconstructie of de exrria-anatomische bypass. (tabel 4.54)

Aontrstompinunficientie. Het optredlen van insufficièntie van de aortastomp hangt samen met persisteren van de infectie. ${ }^{265}$ Veelal is niet alleen de prothese geïfec- 
teerd maar ook de arteriële vaatwand en de omgevende retroperitoneale prochesemantel. ${ }^{200}$ De berekende frequentie in de literatuur van de overzichtstabel (appendix 9.3) werd zoveel mogelijk berekend naar her aantal patienten dat radical wet behandeld en bedraagt $13.7 \%$ (mediaan $12.3 \%$ ) mer een maximum van $30 \%$. In ons patiëntenmateriaal werden 114 patiënten radical behandeld mer in total 24 maal "blow out" van de aortastomp, de vaatnaad van de aorta of een recidief aorto-enterale fistel. (23.9\%) Insufficiëntic van de aortastomp lijki bij AEF meer voor te komen, ${ }^{178,267}$ doch de complicatie was in onze serie gelijkelijk over de beide vormen van infectie verdeeld. Het sluiten van de aorta ging bij 6 patiènten gepaard met technische problemen. Daaruit blijkt dat de aortastomp of de aortanaad cen probleem vormde bij 30 patiënten of $26.3 \%$ van de pariènten die radicial werden behandeld of waarbij de intentie daartoe bestond.

Complicaties van de extra-anatomische bypass. De belangrijkste problemen van de kant van de extra-anatomische bypass zijn infectie en thrombose.

Een infectie van de extra-anatomische bypass ontstond bij 19 van onze 1.22 pariënten $(15.6 \%)$ met een extra-anatomische bypass met een te analyseren follow up. In de liceratuur (appendix 9.3) is het infectiepercentage wan de extra-anatomische bypass bij de behandeling van prothese-infecties hiermee vergelijkbaar mer een gemiddelde van $12 \%$, een maximum van $22.0 \%$ en mediaanwaarde van $12.9 \%$. (zie 2.8.2.5) Vroege thrombose van de extra-anatomische bypass ontstond bij 20 patiënten (16.4\%) en na ontslag thromboseerde de bypass bij 15 pariënten $(12.3 \%$ ). Daarmee komt het thrombosepercentage op $28.7 \%$.

Gegevens over de doorgankelijkheid van de extra-anatomische bypass na radicalc verwijdering van de abdominale vaatprothese worden aangetroffen in 10 van de 40 publicaties van het literatuuroverzicht. De frequentie van afsluitingen van de extra-anatomische bypass varieert daarin tussen 9.5 en $53 \%$ en is gemiddeld $23.9 \%$ (mediáan $21.6 \%$ ).

In de reconstructieve vaatchirurgie is met behulp van de axillo-bifemorale bypass een 5 -jaars' patency rate' te behalen van omstreeks $70 \%$. Dit resultaat word alleen overtroffen door de femoro-femorale cross over bypass. Voor de unilarerale en de bilaterale axillofemorale bypass zijn de resultaten aanzienlijk slechter. ${ }^{14.195} \mathrm{Bij}$ de behandeling van de abdominale prothese-infecties is her niet altijd wenselijk of mogelijk om een axillo-bi-femorale bypass aan te leggen met als gevolg dar de 'patency' van de extra-anatomische reconstructies in die gevallen lager is. ${ }^{1 / 2} .265$ Technische factoren die de doorgankelijkheid verder negatief beïnvloeden zijn end-to-end anastomosen, die retrograde flow onmogelijk maken en distale lokalisatie van de anastomose op de arteria femoralis superficialis, de afteria profunda fémoris of de arteria poplitea in plats van de arteria femoralis communis. ${ }^{195,265}$ Alrernatieve reconstrucries met de autologe vena saphena magna of gedesoblicereerde arteria femoralis superficialis, alleen of als onderdeel van een axillo(bi) femorale bypass ofwel in de anatomische positie, blijken op de lange termijn nier te vol- 
doen. De vena femoralis superficialis is waarschijnlijk een goed altemarief, zowel woor de femoro-femorale cross-over bypass als woor een nieuw aorto-iliacaal systeem. (zie 2.7.5)

Amiputaties. In het literamuroverzicht (appendix 9.3) wordt in 47 artikelen een amputatiepercentage opgegeven. Voor een deel gaat het om de perioperarieve amputaties. Het probleem bij vergelijking is dat nu eens het aantal geamputeerde patiënten wordt opgegeven en dan weer het aantal exrremiteiten 'at risk' en dat de berekeningswijze soms niet vermeld wordt. Het totale amputatiepercentage na behandeling van een geïfecteerde abdominale vaatprothese bedraagt in het literatuuroverzicht, met alle restricties ten aanzien van definities, in- en exclusiecriteria en duur van de follow up, gemiddeld $15.7 \%$ en mediaan $13.3 \%$ met een maximum van $43 \%$. Het aantal perioperatief geamputeerde patiënten in onze serie bedraagt $4.8 \%$ en het totale aantal is $8.9 \%$. Dit lage percentage amputaties kan een gevolg zitn van her relarief lage aantal liesanastomosen, met dienovereenkomstig minder infecties in de lies, waardoor er betere (extra-anatomische) reconstructieve mogelijkheden behouden blijven. Een andere mogelijkheid is dar er bij de exrraanatomische reconstructie een hoger infectierisico wordt genomen. Dat zou ofwel een hoger infectiepercentage ofwel een hoger sterfecijfer van extra-anatomische reconstructie opleveren. Jiet infectiepercentage is vergelijkbaar met het gemiddelde in de literatuur, maar zowel het infectiepercentage als het sterftecijfer kunnen door andere, ernstigere of zich eerder manifesterende, doodsoorzaken gemaskeerd worden.

\subsubsection{MICROBIOLOGIE}

Voor oprimale behandeling van een prothese-infecrie is her noodzakelijk te weten welk micro-organisme eraan ten grondslag ligt. Bij twijfel omtrent het al dan nier bestaan wan een prothese-infectie, kan een grampreparaat behulpzaam zijn.

Grampreparaat. De waarde van een grampreparaat durante operarionem blijkt betrekkelijk en geeft alleen duidelijkheid als er pus wordt aangetoond. In meer dan drickwart $(79.4 \%)$ van de 34 patiënten waarvan durante operationem een grampreparaar werd gemaakr konden bacteriën enlof leucocyten worden aangetoond. In deze gevallen is de betekenis van her grampreparaat duidelijk. Als er macroscopisch duidelijk pus is, is er sprake wan infectie, zeker als dit in overeenstemming is met het klinisch beeld.

Bij de pariènten met een negatief grampreparaat kon de diagnose in vrijwel alle gevallen op andere gronden worden gesteld en bleek her grampreparaat overbodig. (zie 4.4.9) Dit betekent ook dat, een prothese, ondanks een grampreparaat zonder bacterièn, toch geinfecteerd kan zijn. ${ }^{27}$

Kweek. De resultaten van het microbiologisch onderzoek van de prothese zijn in overeenstemming met dargene wat ook in de literatuur beschreven wordt. (zie 
2.3.4) De operatiemortaliteit van de behandeling van de in deze thesis beschreven patiënten met een vroege manifestatie van de infectie, met name de vroeg (binnen 4 maanden) optredende PGI, is hoger dan die van de late infecries (zie 4.5.3.7). Dit fenomen wordt niet in de literatuur beschreven. Wel wordt beschreven dar de vroege infecties worden veroorzakt door de meer virulente soorten bacteriën als $S$ awreus en gram negatieven. De oorzakelijke micro-organismen bij de vroege infecries bleken in overeenstemming met de literatuur ${ }^{10.031}$ overwegend $S$ awrews en gram negatieve micro-organismen te zijn, maar er bleek geen statisisch aantoonbaar significant verschil russen micro-organismen bij vroege en late infecties

Opvallend in onze patiëntenserie is her relatief grote aantal onderzoeken van de prothese dat geen groei van bacterièn oplevert en het geringe aantal kweken met $S$. epidermidis. Bij de 30 pariënten waarbij geen groei van micro-organismen werd gevonden zijn van 23 patiënten $(76.7 \%)$ de peroperatieve bevindingen bekend. Bij 15 van hen (65.2\%) werd beschreven dat er "pus rondom de prothese" werd waargenomen.

Het percentage negarieve kweken bij PGI was significant hoger dan bij AEF. De hospitaalmortaliteit bij de patiënten waarbij de peroperatief afgenomen kweek van de prothese negarief bleef, was significant lager dan bij patiënten met een posinieve kweek. $(p=0.05)$ De frequentie van ontstaan van een infectie van de extra-anatomische bypass was bij negatieve kweek van de prothese eveneens significant lager dan bij patiënten met een positieve kweek. $(p=0.05)$

'Geen groei' kan betekenen dat er geen micro-organismen (meer) waren ten gevolge van de antibiotische behandeling, maar her kan ook betekenen dat er geen micro-organismen zijn gekweekt terwijl ze er wel waren ${ }^{11,16,352,355}$. Dit is bijvoorbeeld typerend voor $S$. epidermidis, een micro-organisme dat zich als verwekker ook kenmerkt door een relatief gunstig beloop van een infectie." Een negatieve kweek van de prothese is onderdeel van de definitie wan cen "low grade" prothese-infectie, waarbij in situ revascularisatie na abdominale protheseverwijdering eventueel gerechtvaardigd zou kunnen zijn. ${ }^{152}$ 



\section{Honnsth}

\section{Conclusie}

Prospecrief vergelijkend onderzoek naar de optimale diagnostiek en behandeling van geinfecteerde abdominale vaatprothesen is om begrijpelijke redenen niet beschikbaar. De incidentie van infecties van abdominale vaatprothesen in Nederland is nier bekend en er bestaat geen eenduidig beleid omtrent de diagnostiek en behandeling van deze infecties.

De pariëntenpopulatie die een infectie van de prothese ontwikkelt kennerkt zich door een groot aantal pre-, per- en direct postoperatieve complicaties bij de implantatie van de prothese, hergeen de gedachte ondersteunt dat de infectie in het merendeel van de gevallen bij de primaire operatie ontstaat. Vasculaire reinterventies in het interval hebben een negatief effect op het infectierisico. Seprische (buik) complicaties in her interval tussen prothese implantarie en manifestatie zijn maar zelden oorzak van de prothese-infectie. Het infecrierisico kan derhalve verminderd worden door de pre-operatieve conditic van de patiënt te optimaliseren door opsporing en behandeling van bestaande ziekten en infecties en een miniricuze pre-operatieve voorbereiding, door een strikte aseptische en atraumatische operatietechniek en het voorkomen van thrombose of nabloeding door een stringente indicatiestelling en toepassing van de juiste reconstructietechnieken.

Een infectie van een abdominale varprothese kan vrijwel zonder kinische verschijnselen bestaan maar zich ook manifesreren als een ernstige sepsis en vrijwel alle gradaties tussen deze beide uitersten. Een blootliggende prothese in een wond of een vanuit het darmlumen zichbare prothese is per definicic geinfecteerd.

Her uitgebreide scala verrichte diagnostiek, ook war dit niet meer strikt noodzakelijk was, doet vermoeden dat de klinische verschijnselen niet voldoende herkend worden of dat er geaarzeld wordt ten aanzien van het accepteren van de diagnose hetgeen een snelle en adekware behandeling in de weg staat. Voor de diagnostiek van de prothese-infectie komen computertomografie en isoropenscintigrafie als eerste in aanmerking. Met behulp van sinografie kan worden aangetoond dat de prochese los ligt maar nier over welk traject. Praktische richdijnen voor rarionele diagnostiek bij de verschillende presentatievormen van een mogelijk prothese-infect zijn samen te vatten in een algorithme. (figuur 7, sectie 5.4.3)

Door grote onderlinge verschillen in de samenstelling van de beschreven series buirenlandse patiènten en de door ons beschreven patiënren, woornamelijk ren ge- 
volge van selectie en verschillen in her niveau wan de distale anastomosen, is vergelijking maar ten dele mogelijk. De behandeling van de prothese-infecties in ons onderzoek, en waarschijnlijk in Nederland, evenals in de literarutur, lijkr voor een groot deel op selectie te berusten, waarvoor een werenschappelijke basis ontbreekr. Voor zover vergelijking mogelijk en verantwoord is, stemmen de bereikte resultaten van de behandeling in de onderzochte serie patiënten redelijk overeen mer de gemiddelde resultaten in de literatuur, terwijl uir elders bereikte resultaten blijkt dat verbetering mogelijk is. De operatiemortaliteit van de radicale behandeling was gemiddeld $43.9 \%$. De beste resultaten werden bereikr bij de behandeling van de lat optredende PGI. De berekende gemiddelde operatiemortalireit in de lireratuur is $21 \%$ voor de PGI en $46 \%$ woor de AEF. Het best gepubliceerde resultaat betreft een operatiemortaliteit van 16\%. De overleving van $16.9 \%$ na 5 jaar voor de radicale behandeling is aanzienlijk minder dan in de Americaanse literatuur wordt vermeld.

De radicale behandeling, of verwijderen van de prothese, is op theoretische gronden de enige juiste en de enige behandeling die technisch vrijwel altijd uitvoerbaar is. Zeker bij de PGI kent deze behandeling echter een (te) hoge mortaliteit, maar de mediane overlevingsduur is na die behandeling is bijna rwee keer zo lang dan na niet radicale behandeling.

Er zijn geen duidelijk bekende condities waaronder niet-radicale behandeling verantwoord is en de resultaten leidden in tweevijfde van de gevallen alsnog tor radicale behandeling. De resultaten van de niet-radicale behandeling zijn zelfs nier bij benadering te vergelijken met literatuurgegevens. Als de uitbreiding van de infectie met zekerheid vast te stellen zou zijn, zou bij een gesellecteerde patiëntenpopulatie, op grond van de levensverwachting en de conditie van de patient, het oorzakelijk micro-organisme en het klinisch beeld, niet-radicale of in 'situ' behandeling verantwoord kunnen zijn.

Selectie zou plaats kunnen vinden op basis van cen gestandariseerde analyse van de conditie van de patiënt, de uitkomsten van de diagnostiek, het oorzakelijk microorganisme en mogelijk een aantal nog te bepalen factoren.

Centrale registratie van infecties van alle operaries met vaatprothesen en hun complicaties, is de enige manier om meer kennis omtrent beloop, diagnostiek en behandeling te vergaren en richtlijnen op te stellen ten einde de resultaten van de behandeling te verbeteren. 


\section{HoOnDSTH? \\ Samenvatting}

De laarste vier decennia was de kunststof vaatprothese een hoeksteen woor de chirurgische behandeling van zowel dilaterende als oblitererende afwijkingen van de grote vaten. Het gebruik ervan creëerde echter tegelijkertijd een aantal nieuwe specifieke chirurgische complicaties waarvan infektie de meest geduchte is. Vooral bij infecties van abdominale vaatprothesen worden patiënten en varchirurgen geconfronteerd met een calamiteit die vaak leidt tot het verlies van extremiteiten of de dood van de patiënt.

Dit proefschriftbevat een analyse van 154 patiënten met cen infectie van cen abdominale vaarprothese die in een rwaalfjarige periode van 1982 tot 1994 werden behandeld in 5 Nederlandse universiteits- en 6 opleidingsziekenhuizen.

Hoofdstuk 1 bevat een korte inleiding en vraagstelling omtrent de problematick van de eriologie, klinische presentatie, diagnostiek en behandeling van deze infecties en de resultaten daarvan.

Hoofdstuk 2 bestaat uit een overzicht van de literaruur, de gebruikre definities van begrippen die worden gebruikt bij infectieuze complicaties in de vaatchirurgie waarbij de pathofysiologie van de prothese en risicofactoren bij het ontstaan van een infectie aan de orde komen. Er wordt een overzicht gegeven van de klinische presentatie, de diagnostische mogelijkheden en de behandelingsprinciepes. De moeilijkheden van vergelijking met gegevens uit de literatuur ten gevolge van selecrie en verschillen in definities worden geanalyseerd. Ondanks deze problemen is getracht mortaliteits- en complicatiegegevens uir de literatuur te verzamelen en in een tabel onder te brengen. (appendix 9.3)

Hoofdstuk 3 bevat de gegevens over material en methoden. Retrospectief werden gegevens verzameld over de primaire operatie, de complicaties en de chirurgische interventies in het interval tussen implantatie van de prothese en her stellen van de diagnose, de klinische presentatie, de diagnostiek van de infectie en de behandeling evenals de resultaten daarvan.

Hoofdstuk 4 bevat de resultaten wan her onderzoek. De primaire operatie werd in $40.1 \%$ wegens oblitererend en in $59.1 \%$ verricht wegens dilaterend vatijden. Binnen de eerste 30 dagen ondergingen 43 pariënten 76 réoperaties en in het interval hierna werden nog eens 243 operaties verricht bij 92 patienten. Symptomen in de lies waren de eerste klinische verschijnselen bij $33.1 \%$, terwijl $27.9 \%$ zich 
presenteerde met gastro-intestinal bloed verlies en $39.0 \%$ met systemische verschijnselen. Computertomografie en isotopen onderzoek leverden het hoogste percentage aan positieve bevindingen op. Bij operatie bleek bij $59.7 \%$ van de patiènten een perigraft infectie te bestaan en bij $40.3 \%$ een aorto-enterale fistel. De operatieve behandeling kon worden verdeeld in ingrepen met radicale $(60.4 \%)$ of met niet-radicale verwijdering van de prothese $(20.8 \%)$. Een derde groep bestond uit patiënten waarbij de prothese pas na mislukte lokale behandeling werd verwijderd. (13.6\%) Gegevens over ingroei van de prothese werden in $75 \%$ van de operatieverslagen gevonden en de resultaten van microbiologisch onderzoek konden worden gevonden in $67 \%$. Bij $3.5 \%$ van de patiënten werd geen revascularisatie verricht. Extra anatomische revascularisatie vond plaars bij $91.2 \%$ van de radicale operaties en bij $71.9 \%$ van de niet-radicale operaties. In situ revascularisatie werd slechrs bij 6 patiënten verricht, bij 2 met prothese en bij 4 met autoloog materiaal. De gemiddelde zickenhuissterfte bedroeg $40.4 \%$. Beschreven worden de morbiditeits- en mortaliteitscijfers evenals de lange termijn resultaten tot het einde van de studie in 1995.

De discussie volgt in hoofdstuk 5 waarin een vergelijking wordt gemaakt met de uit de literatuur bekende resultaten van diagnostiek en behandeling van abdominale prothese-inlecties.

Conclusies volgen in hoofdstuk 6. Prospectief onderzoek naar de optimale diagnosrick en behandeling van de geïnfecteerde abdominale vaatprothese is niet beschikbaar en preventie hangt samen met de kennis van de pathofysiologie van deze infecties. Het hoge percentage pre-, per-, en postoperatieve complicaties bij de primaire operatie en de daarbij behorende vroege reinterventies vormen waarschijnlijk een belangrijke oorzaak voor het ontstaan van de infektie. De late rënterventies spelen mogelijk nog een belangrijkere rol. Moeilijkheden bij bevestiging van de diagnose en het accepteren daarvan weerspiegelt zich in het het uitgebreide gebruik van de diagnostische mogelijkheden, zelfs als de diagnose al duidelijk was, terwijl langdurige diagnostick een snelle behandeling in de weg staat. Verschillen in de samenstelling van de series en niet wetenschappelijk gefundeerde selectie maakt vergelijking met in het buiterland bereikte resultaten moeilijk. Voor zover vergelijking mogelijk en verantwoord is benaderen onze resultaten ongeveer de uitkomsten zoals die in de literatuur worden weergegeven. De toekomsrvisie is een landelijke registratie om verdere studie mogelijk te maken. 


\section{Summary}

During the last four decennia the widespread use of prosthetic arterial substitures has been one of the mainstays of surgical treatment of arterial aneurysmatic and occlusive diseases. This has also created a range of new and specific surgical problems of wich prosthetic infection is one of the most dreaded ones. Especially in abdominal graft infection patients and vascular surgeons are faced with a carastophe often leading to limb loss or death of the patient.

This thesis is an analysis of aortic graft infections of 154 patients who were treated over a period of 12 years from 1982 to 1994 in the Netherlands in 5 university hospitals and 6 reaching hospitals.

Chapter 1 consist of a short introduction including the rationale for this thesis concerning questions of etiology, clinical presentation, diagnostics, trearment and results of treatment of abdominal graft infections.

Chapter 2 presents an overview of the literature about abdominal aortic graft infection including definitions and terminology of septic complications of vascular procedures. Atrention is payed to parhobiology of the graft surface and risk factors contributing to graft infection. In this chapter a review is presented of clinical presentation and the various modalities available for diagnosis. Principles of treatment and technical details are discussed. Difficulties in analysing literature data as a consecuence of differences in definitions and as a result of patient selecrion are discussed. In spite of all these difficulties, data concerning patients, diagnosis, trearment and results of treatment available are summarized and an artempt is made to analyse data concerning mortality and complications in literature.

Chaprer 3 describes methods and materials of our study. Retrospectively dara were collected about the primary implantation of the ultimately infected prosthesis, the complications and the surgical interventions in the interval period between the implantation of the prosthesis and the confirmation of its infection, the presenting symptoms of infection, the diagnostic methods and the details of surgical treatment of the infecrion and the results of short term and long term treatment.

Chapter 4 presents the results of this study. The primary operanion was performed for aortoiliac aneurysmatic disease in $59.1 \%$ and for occlusive disease in $40.1 \%$. Within the first 30 days 43 patients underwent 76 reoperations and in the interval after this period a total of another 243 operarions were performed in 92 patients. 
Local evidence of infection was the presenting dinical symptom in $33.1 \%$, gastro intestinal bleeding in $27.9 \%$ and systemic evidence of infection in $39.0 \%$. CT scanning and isorope scintigraphy were found to be the best diagnostic tools. According to operative findings $59.7 \%$ of the patients had a perigraft infection (PGI) and $40.3 \%$ a graft enteric fistula (AEF). The operations to treat the infection were divided in radical procedures in wich the abdominal prosthesis was removed complerely $(60.4 \%)$ and non-radical procedures in wich he abdominal prosthesis was removed only pardy or not at all. (20.8\%) When a non-radical procedure was followed by a radical procedure this was called a secondary radical procedure (13.6\%). Reliable data about surrounding fluid and ingrowth of the prothesis were available in $75 \%$ of the operation records, and the results of intraoperative microbiologic specimens in $67 \%$. No revascularisation was performed in $3.5 \%$, extra-anatomic revascularisation, in $91.2 \%$ of radical procedures and $71.9 \%$ of non-radical procedures. In situ revascularisation was performed in only $6 \mathrm{pa}-$ tients, 2 with prosthesis and 4 with autologous material. The mean hospital mortality was $40.4 \%$. Detailed morbidity and mortality figures of these procedures are presented including the longterm fate of of the survivors until closure of the study in 1995.

Chapter 5 provides a general discussion. A comparison of the results of our study is made with those known from the literature review.

Chapter 6 presents the conclusions. Controlled trials of the optimal diagnostics and treatment of infected aortic prosthesis are not available and prevention depends on knowledge of pathophysiology. The very high rates of pre- per- and postoperative complications of the primary implantation and the subsequent reoperations of the infected prosthesis probably play an important role in the development of prosthetic infection. The late reoperations in the interval are probably even more important. The use of a considerable number of diagnostic procedures, even when the diagnosis was obvious, is an indication of the difficulties in confirming and accepting the catastrofic diagnosis of abdominal prosthetic infection and prevents prompt treatment.

As a consequence of a non scientific selection and a higher number of bifemoral reconstructions in other series, literature data are hardly comparable with our data. As far as comparison is possible and justified, results in our series are approximateIy similar to those in literature and illustrate the dramatic narure of this complication. Further study in the future can only be accomplished after registration of all prosthetic vascular surgery and its complications. 


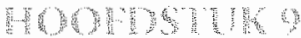

\section{Appendix}

\subsection{MICROBIOLOGIE}

De resultaten van her microbiologisch onderzoek van het lichaamsmateriaal dat peri-operatief bij de primaire operatie en bij de behandeling van de infectie werd verzameld, is achteraf onderverdeeld in monoculturen en menginfecries. De aldus ontstane categorieèn zijn als volgt samengesteld:

monoculturen

gram positieve coccen

1 staphylococcus aureus

2 staphylococcus epidermidis (albus)

3 andere gram positieve coccen en streptococcen

staphylococcus saprophyticus

str faecalis (enterococcus)

str beta-haemoliticus

str viridans

str milleri

pneumococcen

4 gram negarieve coccen

enterobacter

proteus

thaemophylus

klebsiella aerogenes, cloacae, pneumoniae

pseudomonas, xanthomonas,

enterobacteriaceae, E coli

neisseria, gonorrhoae, meningitides

salmonella

shigella

morganella

pasteurella, legionella shigella,brucella

gram negatieve staven

serratia

acinetobacrer

andere gram negatieven

5 gram positieve staven 


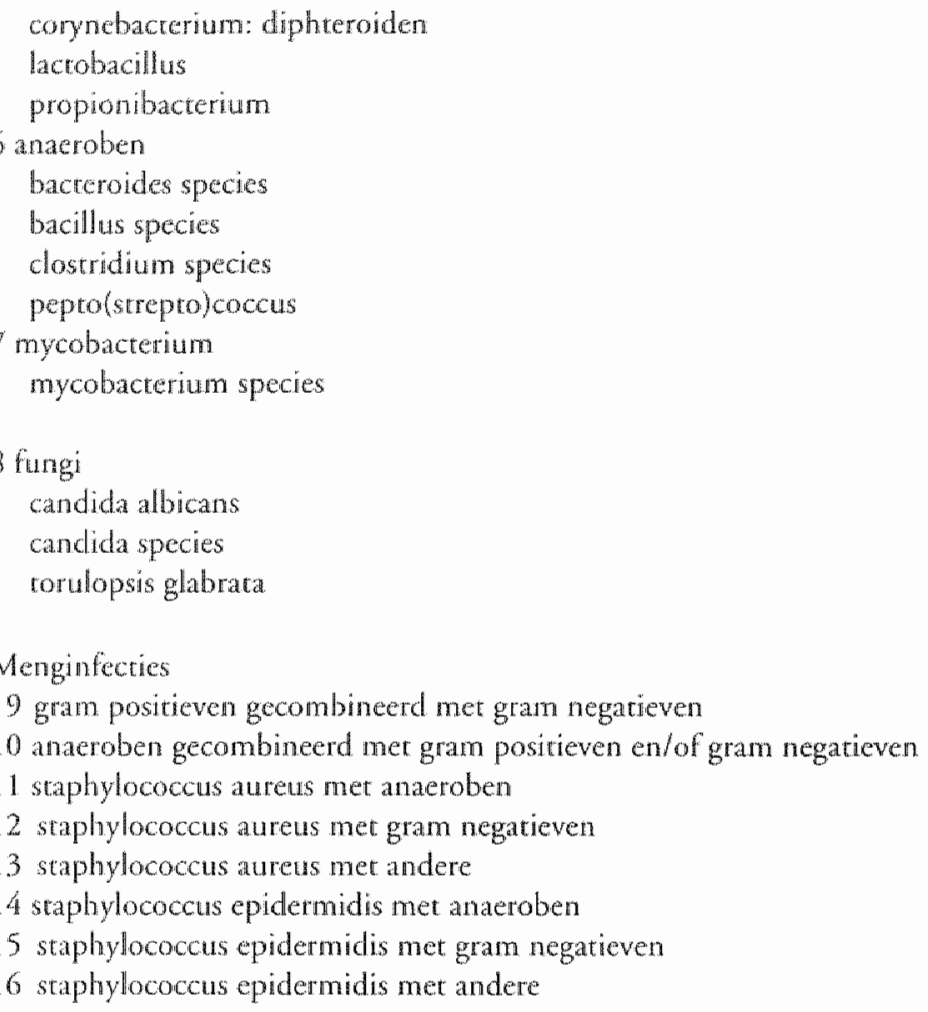

\subsection{ANTIBIOTICA}

De verschillende antibiotica werden, op basis van hun pharmacologische eigenschappen onderverdeeld in de volgende groepen:

Penicilinen:

ampicilline

amoxycilline

Moxapen

augmentin

Cethalosporinen:

ceporex

mandol

cephamandol

claforan

kefrol

forrum

keflin

keforal 
zinacef

Aminoglycosiden:

gentamycine

kanamycine

tobramycine

Quinolonen:

ciproxin

Glycoproteinen

varicomycine

Macroliden:

erythromycine

Metronidazol

Combinaties van twee of meer tegelijk gebruike antibiotica:

aminoglycoside met cephalosporine

aminoglycoside mer penicilline

penicilline met cephalosporine

aminoglycoside mer penicilline en metronidazol

cephalosporine mer metronidazol

overigen

\subsection{LITERATUUROVERZICHT}

Het literatuuroverzicht bevat een overzicht van de publicaties over diagnostiek en behandeling van geinfecteerde abdominale vaatprothesen vanaf 1980 . Bij het verzamelen van de resultaten zijn voor al deze begrippen zoveel mogelijk de definities gehanteerd zoals ze in Hoofdstuk 3, "Materiaal en methoden' zijn omschreven. Waar dar niet mogelijk was zijn de resultaten opgenomen zoals ze door de auteurs zijn gedefinieerd.

In de eerste kolommen staan de auteurs vermeld met her jaartal van verschijnen van het artikel en het refentienummer. Daarna volgt de duur van de periode waarop her verslag betrekking heeft, het aantal daarin opgenomen patienten met een abdominale vaatprothese volgens onze definitie, (zie 3.3.1) en de onderverdeling in aantallen buisprothesen, bi-iliacale prothesen en bifemorale prothesen.

Op grond van de door de auteur meest verrichte of aanbevolen behandeling. is van de geanalyseerde literatuur een indeling gemaakt in vier categorieën, op basis van het al dan niet radicaal verwijderen van de prothese of op basis van de wijze waarop de revascularisatie plaats vond: De radicale behandeling en de niet-radicale behandeling, en de autologe en de 'in situ' revascularisatie.

Er zijn auteurs (de meerderheid) die meerdere behandelingen toepassen, wardoor een zekere overlap ontstaat. In de kollom radicaal zijn de aantallen patiënten opgenomen die werden behandeld door de prothese volledig te verwijderen en de on- 
derste extremiteiten te revasculariseren door middel van een extra-anaromische bypass. De aantallen patiënten waarbij na verwijderen wan de geînfecteerde prothese autologe of 'in situ' behandeling plaars vond zijn apart vermeld in de betreffende kolommen. Alle vormen van behandeling waarbij de prothese niet of partieel werd verwijderd zijn ondergebracht in de groep "niet radicale behandeling. Onder geen behandeling zijn de patiënten ondergebracht die pré- of peroperatief overleden. In de daaropvolgende kolom staan de aantallen patiënten die niet werden gerevasculariseerd

De kolommen daarna bevatren de totale operatiemortaliteit in procenten en de onderverdeling naar mortaliteitspercenrages voor de verschillende behandellingen en revascularisatiemethoden apart. In de daaropvolgende kolom staar de totale door de auteur opgeven mortaliteit. Voor een aantal arrikelen is dit gelijk aan de operatiemortaliteit, en voor andere geldr dar dir de mortaliteir is vanaf de operatie tot an het einde van de follow-up periode. (laatste kolom). Voor de mortaliteir worden verschillende definities gebruikt. Het kan de totale mortaliteit zijn of de uitsluitend an de infectie gerelateerde mortaliteit, terwijl de duur van de observatieperiode sterk kan varieren. De daaropvolgende kollommen geven achrereenvolgens de percentages pariënten met persisterende infectie na niet-radicale behandeling, met naad- insufficiëntie van de aortastomp (blow out) en het amputatiepercentage. Bij beide laatste percentages kan het om peri-operatieve of de totale percentages gaan $V$ oor het amputatiepercentage is niet altijd duiclelijk of dit berekend is over het aantal patiënten of het aantal extremiteiten 'at risk'. De infecries en thrombosepercentages van de extra-anaromische bypass in de daaropvolgende kolommen zijn totale percentages (peri-operatief, al dan niet inclusief follow up). De duur van de follow-up, staat in de laatste kolom vermeld. 


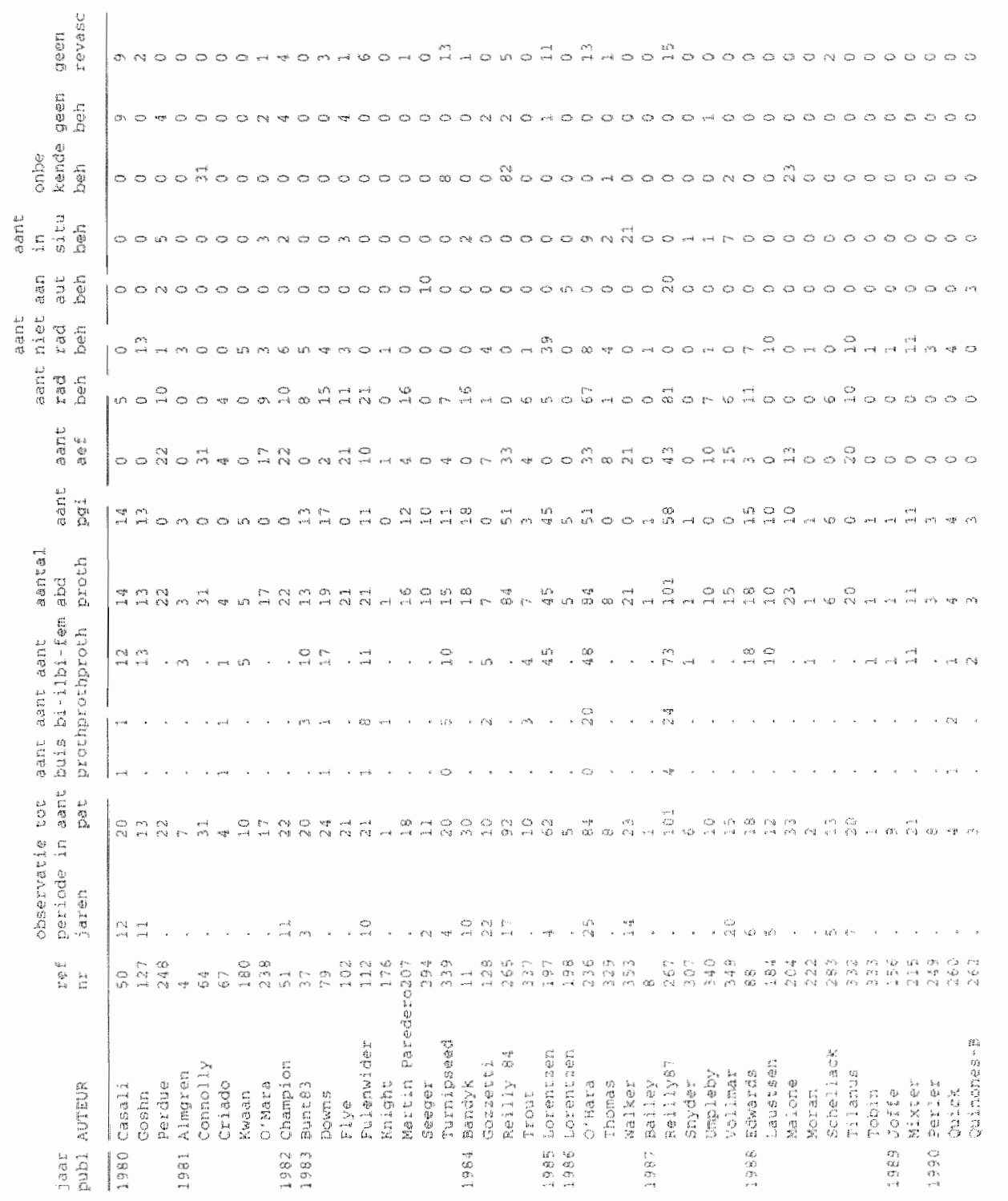




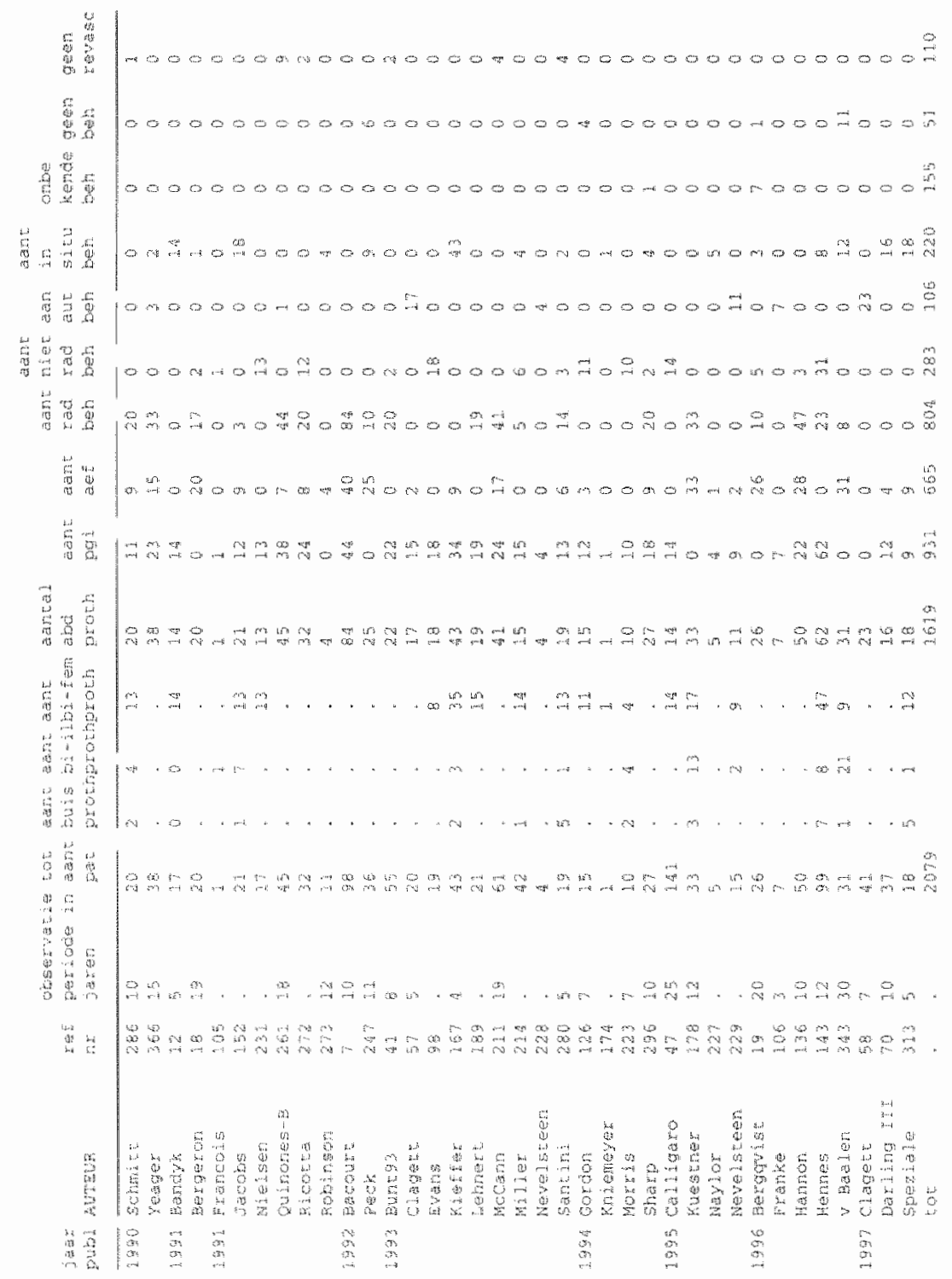




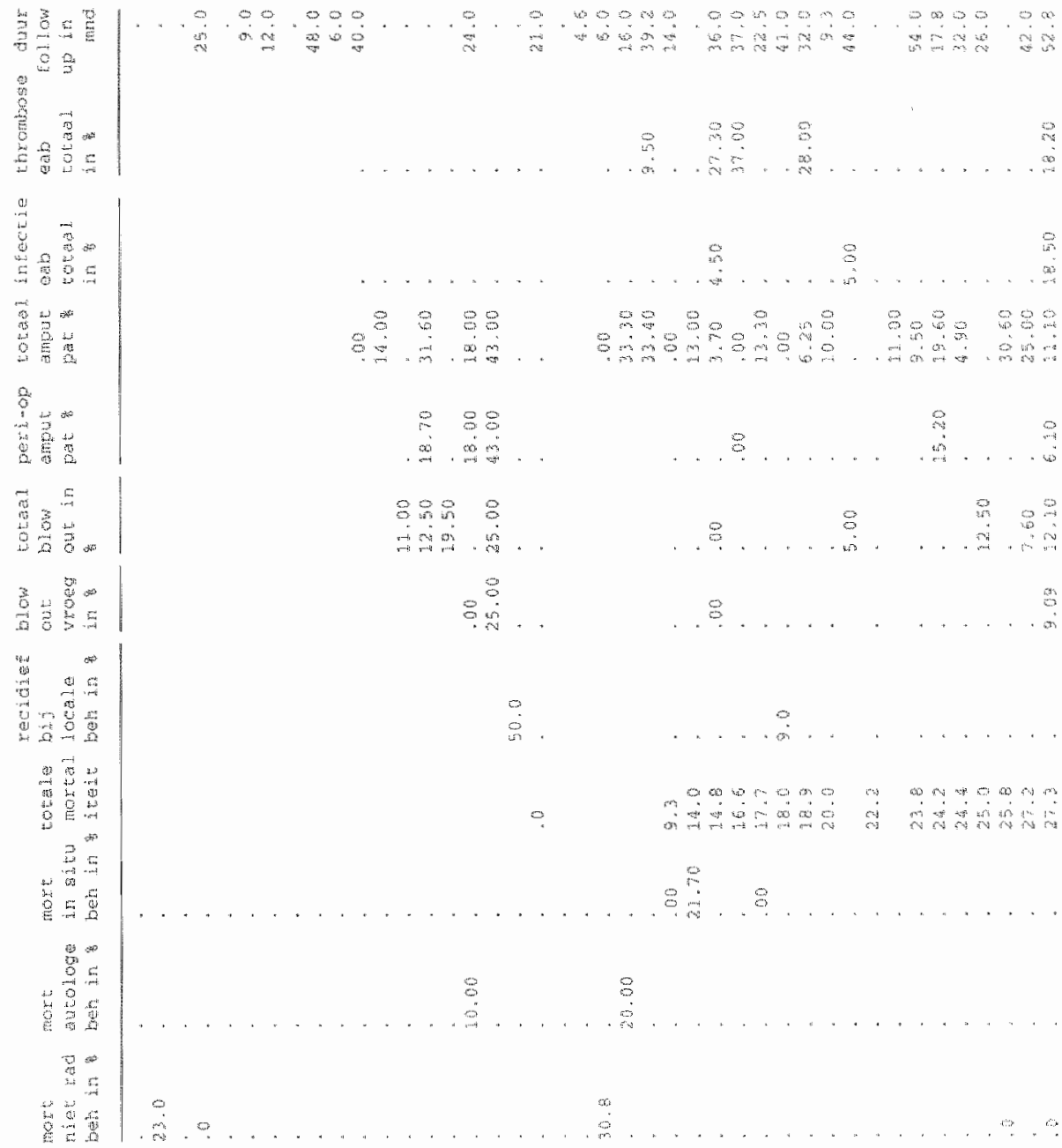

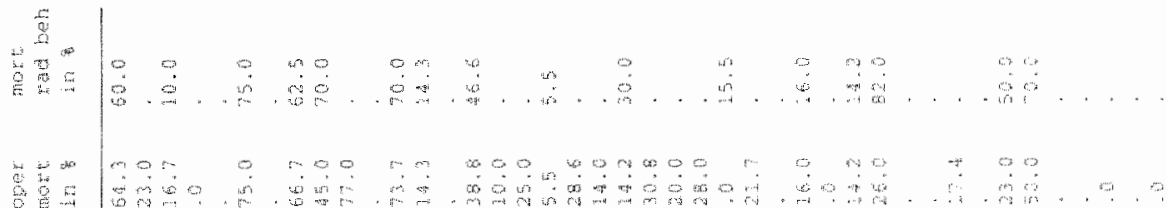

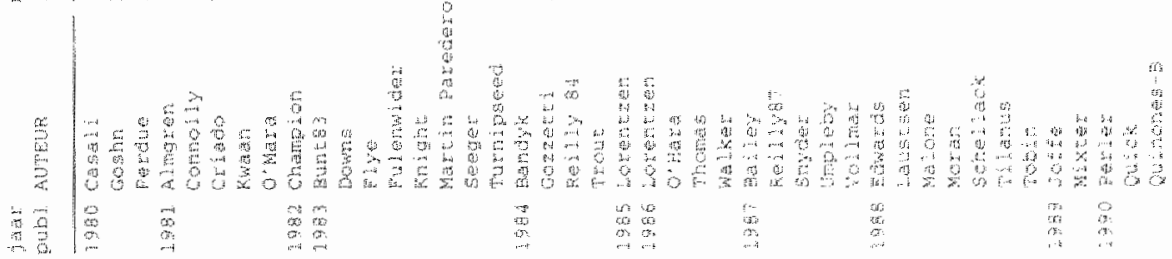




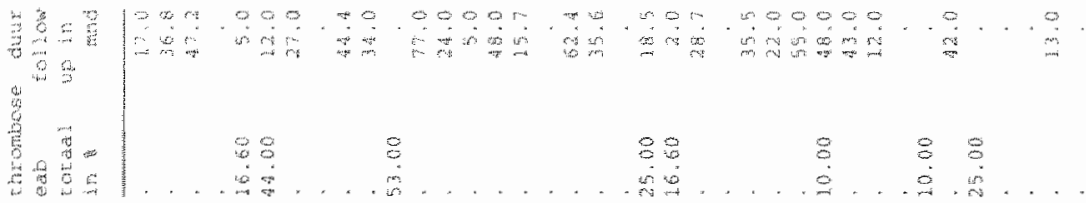

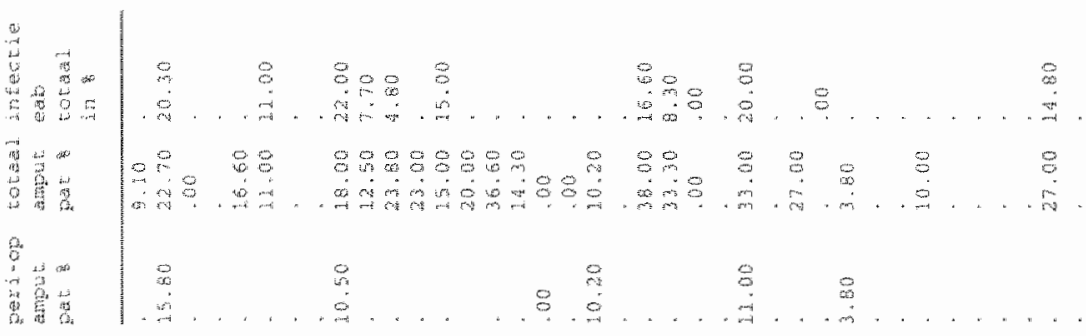

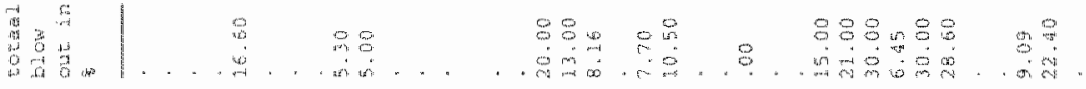

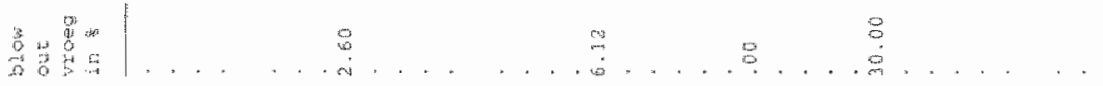

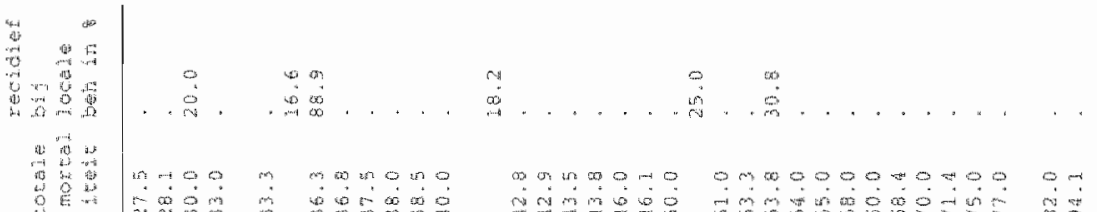

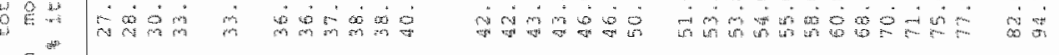
\begin{tabular}{l|l}
3 \\
0
\end{tabular}

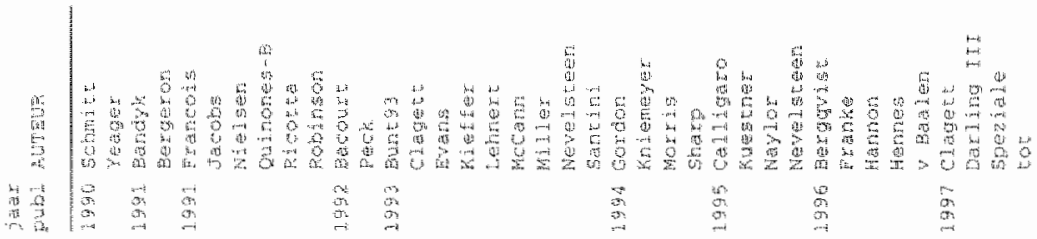




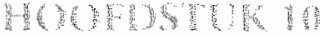 \\ Bibliografie}

1 Abet D, Pierri- False aneurysms in prostheses of the artic bifurcation. Apropos of 34 case reports. I Mal Vasc 11:270-4,1986.

2 Alazraki NP, Mishkin FS. Inflammatory and infectious processes. In Aazraki NP. ed Fundamentals of nuclear medicine. New York: The Society of Nuclear Medicine: 1984.

3 Alemany ). Montag $\mathrm{H}$, Görz $\mathrm{H}$, Wozniak $\mathrm{G}$. Die tiefen Beinvenen als Gefássersatz bei femorocruralen Rekonstruktionen: Indikation, Früh- und Spätergebnisse. Angio Archiv 21: 98,1991 .

4 Almgren B, Eriksson I. Local antibioric irrigation in the treatment of arterial graft infecrions. Acra Chir Scand 147:33-36,1981.

5 Ameli FM, Weiss M, Provan JL, Johnston KW. Safety of cholecystectomy with abdominal aorric surgery. Can-J-Surg. 30: 170-3,1987.

6 Aufferman W, Olofson PA, Rabahie GN. Incomporation versus infection of recroperitoneal aortic grafts: MR imaging fearures. Radiology 172: 359-362, 1989.

7 Batow F, Koskas $\mathbb{F}$, and the French University Association for Research in Surgery. Axillobifemoral bypass and aortic exclusion for vascular sepric lesions: A multicenter retrospecrive studyr of 98 cases. Ann vasc Surg: 6:119,1992.

8 Batly $1 S$, Bundred NJ, Pearson HJ, Bell PRF, Succesfull treament of an infected wascular graft with Gentamicine beads. Eur I Vasc Surg 1:143-144, 1987.

9 Baker MS, Fisher JH, Van Der Reis L, Baker BH. Endoscopic diagnosis of an aorto-duodenal fistula. Arch Surg 111: 304,1976.

10 Bandyk DF, Esses GE: Prostheric graft infection. Surg Clin N Amer 74:571-589, 1994.

11 Bandyk DF, Berni GA, Thicle BL. Towne JB. Aortofemoral grafe infection due to staphylococous epidermidis. Arch Surg 119:102-108,1984.

12 Bandyk DF, Bergamini TM, Kinney EV, Seabrook GR, Towne JB. In situ replacement of vascular prosthesis infected by bacterial biofims. J Vasc Surg 13:575-583.199!.

13 Becker RM. Blundell PE. Infecred aortic bifurcation grafts: Experience with fourreen parients. Surgery 80: $544 \times 1976$.

14 Bension RS, Williams RA, Wilson SE. Sugical management of unilateral groin infection after aortofemoral bypass. Surg. Gynccol, Obster. 156:724-728,1983.

15 Bennion RS, Williams RA, Wilson SE. Comparision of infecrability of vascular prosthetic marerials by quanritation of median infective dose. Surgery 95:22-26,1984.

16 Bergamini TM. Parlobiology of the graft surface, Bacterial biofilm. In: Vascular graft infections. T.J. Bunt, Futura publishing. New York 1994.

17 Bergamini $/ M$, Bandyk DF, Gowostis D, Vesch R, Towne JB. Identifation of staphylococcus epidermidis in vascular graft infections: a comparison of culture techniques I Vasc Surg:9: 665-670, 1989. 
18 Bergeran P, Espinoza H, Rudondy P. Ferdani M, Martin Jo Jausseran J, Courbier R. Secondary aorroduodenal fistulas: value of initial axillofemoral bypass. Ann Vasc Surg 5:4-78, 1991

19 Bergavit D, Björkman H, Bolin T, Dalman P, Elfström jer all. Secondary aortonteric Istulla: Changes from 1973-1993. Fur I Vase Endovasc Surg 11: 425-428, 1996.

20 Bergytust $D$, Biörk $M$. Bowel ischaemia after awroiliac surgery. $\mathrm{Br} J$ Surg $84: 593-594: 1997$.

21 Bermats $S S_{*}$ Bernard VM. Significance of posirve lntraoperarive arterial wall cultures. in: Mamagement of infected anterial grafts Calligaro KD, Veith $\mathbb{E l}$ eds. Quality Medical publishing, Ine St Louss, Missouri. 1994.

22 Bemard VM. Aonownto frstulas In Rwtherford RB, ed. Vascular surgery, 3rd ed. Philadelphia: WB Saunders. 1989.

23 Bickerstaff LK, Hollier LH, Var Peenan HS, Melton LJ, Pairolara PC, Cherry KK. Abdominal aortic aneurysm repair combined with a second procedure, morbidity and mortaliry. Surgery 95:487-491,1984.

24 Björck $M$. Troöng T, Bergquist D. Risk factors for intestinal ischaemia after aortoiliac surgery: a combined cohorr and case control study of 2824 operarions. Eur J Vasc Endovasc Surg 13:531-539,1997

25 Blaisdll FW, Hall AD. Axillary-femoral artery bypass for lower extremiry ischemia. Surg $54: 563,1963$.

26 Blakemore AH, Voorhees $A B$. The use of tubes constructed from vinyon ' $N$ ' cloth in bridging arterial defects: experimental and clinical. Ann Surg 140:324-334,1954.

27 Blongren $G$, Hambreus A Malmborg AS. The influence of the toral body exhaust suit on air and wound contamination in elecrive hip operarions. I Hosp Infect 4: 257-268, 1983.

28 Bosman CHR. Report on 20 years of experience with arherosclerotic aneurysms of the abotominal aorta. Thesis Leiden 1983. ISBN 9070062062.

29 Bonhorsos J. Chavatsas D, Martin P. Morris T. Infected sytheric arterial grafts. Br] Surg 61:108-111,1974.

30 Brandimate C, Santini C, Venditri M, Baiochi P, Serra P, Gallo P, d'Amari P, Rizzo L Speciale ${ }^{-}$, Figrani $P$. Clinical significance of intraoperative cultures of aneurysm walls and contents in elective abdominal aortic aneurymectony. Fur J Epidemiol 5:521-525,1989.

31 Briker DL, Beall AC. DeBakey ME. The differencial response to infection of autogenous vein versus Dacron arterial prosthesis. Chest 58: 566-570,1970.

32 Brock RC. Aortic Homografring. a report of six succesful cases. Guy's Horp Ref $102: 204,1953$.

33 Brok I. Role of anactobic bacteria in atrofemoral grafe infection. Surgery 104:843-845,1988.

34 Brwmer MC, Mitchell RS, Baddwin JC, et al, Prostheric graft infection: Limitations of indium white blood ell scanning. I Vase Surg 3:42-48,1986.

35 Buckels $/ A C$, Wilson $S E$. The prevention and management of prostheric graft infection. In Wilson SE, Veith FJ, Hobson RW, Williams RA, eds. Vascular Surgery: Principles and pracrice. New York: McGraw-Hill, 1987.

36 Buckels AC. Ficlding JWL. Black J. Ashton F and Slaney G. Significance of positive bacterial culures from aortic aneurysm contents. Br J Surg 72:440-442,1985.

37 Bunt Th. Synthetic vascular graft infeccions: part one: graft infections. surgery $93,733-746,1983$. 
38 Bunt Ty, Vascular graft infections: part rwo: graft emteric erosions and fistula. Surgery 94:1-9,1983.

39 Bunt Ty. Haynes JL. Symheric vascular grafuinfection, Th concinuing headache. The Americam Surgeon 50:43-48,1984.

40 Bunt Ty. Mohr JD. Incidence of positive inguinal lymf node culture during pripheral revascularisation. Am Surg 10: 522-523,1984.

41 Bunt TJ. Vascular gaft infecrions: a personal experience. Cardiovascular surgery 1 . $489-492,1993$.

42 Bunt TJ. Vascular grafr infecrions. Furura Iublishing Company, Inc. Armonk NY. 1994,

43 Busuttil RW, Rees WR, Baker JD, Wilson SE. Pathogenesis of aorro-duodenal fistula: Experimental and divical correlates. Surgery 85.1013 .1979$.

44 Calligaro KD, Veith FJ eds Managenent of infected arterial graft. Quality Medical Publishing, Inc. Sr Lohis, Missouri, 1994.

45 Calligaro KD, Veith FJ, Gupta $S K$ er all. A modifed method for managenent of prostheric graft infections involving an anastomosis to the common femoral artery " Vasc Surg $11: 485-492,1990$.

46 Calligaro KD, Veith $\mathbb{F}$, Schwartz MI et all. Are gram negative bacteria a contraindication to selecrive preservation of infected prostheric arterial grafts? I Vasc Surg $16: 337-346,1992$.

47 Calligaro KD, Veith FI, Schwartz MI. et all. Differences in early and late extracavitary arterial graft infecrions. J Vasc Surg 22:680-688,1995.

48 Carlson $A S$, Josefson $G$, Lindberg $L$. Rewision with gentamicin-impregnated cemen for deep infections in total hip arthroplasties. I Bone Joint Surg Am 60: 1059-1066, 1975.

49 Carter SC, Cohen A, Whelan T]. Clinical experience with managenent of the infected Dacron graft. Ann Surg 158:249-255,1963.

50 Casals RE, Tucker WE, Thompson BW, Read RC. Infected prostheric gratts. Arch Surg $115: 577-580,1980$.

51 Champion MC. Sullivan SN, Coles JC, Goldbach M, Watson WC. Aortoenteric fistula, Incidence, presentation, recognition, and management. Ann Surg 195:314-317, 1982,

52 Chan F, Crawford E, Coselli J et al. In situ prosthetic graft replacement for mycoric aneurysm of the aorta. Ann Thorac Surg 47:193-202,1989.

53 Chee RC, Cole FH, Smirh HF. Comparison of Dacion and aorric autografts in wounds concaminated with fecal mater. Am Surg 40: 439-462, 1974 .

54 Christerson GD, Simpson WAx Bisno AL. Adherence of slime-produciog strains of staphylococcus epidermidis to smooth surfaces. Infect Immun. 37:318-326,1982.

55 Christensen RD, Bematz PE. Anasromonic aneurysms involwing the femoral arrery. Mayo Clin Proc 47:313-317,1972.

56 Claget $G P$, Salander JM, Eddlemann WL, Dillatation of kmined dacron aoric prosthesis and anastomotic false aneurysms: eriologic considerations. Surgery 939-16,1983.

57 Cluget $G P$, Bowers BL, Lopez Viego MA, Rossi MB, Valentine RI, Myers SI Charwu A. Creation of a neo-aoric system from lower extremty decp and superficial veins. Anu Surg $218: 239-249,1993$

58 Clagert GP, Valentine RJ, Hagino RT. Aurogenous aorro-ilne/femoral reconstruction from superficial femoral popliteal weins: Feasibility and durabilicy. I Vasc Surg $25: 255-270,1997$.

59 Clayor H. Birch L, Cardwell ES, Zirnmerman SL. Suture-line rupture of a Nylon aontic bifurcarion grafe into the small bowd. Arch Surg 73:947.1956. 
60 Cowes AW, Kirkman TR, Reidy MA. The mechanisms of arterial graft healing. Am I Pathol $1232220-230_{n} 1986$

61 Cogbill TH. Secure aortic stump closure with autogenous vein pledgers. Surgery 96: $940-941.1984$.

62 Cohen $/ R_{0}$ Perry $M O$, Hariri $R$ ea Aortic collagenase activicy as affected by laparoromy, cecal resection, aortic mobilisation and atortotomy in rats.

63 Colbum MD. Moore WS, Chvapil M, Gelaber HA, Qunones-Baldrich WJ. Use of an antibiotic-bonded graft for in siru reconsmuction afrer prosthetic graft infections. I Vasc surg 16: 651-661.1992.

64 Connolly If, Kwan JHM, McCart $\mathbb{P}$, Brownell DA, Levine EF. Aortoenteric fistula. Ann Surg 94:402-412,1981.

65 Crauford ES. Evaluation of hte failures after reconstructive operations of the arora, femoral and popliteal arteries. Surgery $47779-104,1960$.

66 Crech O. Detering RA, Edwards S, Julian OK, Linton RR. Vascular prosthesis (Report of the commitree for study of vascular prothesis of the society for vascular surgery). Surgery 41:62, 1957 .

67 Criado Ff. Classen JN, Wilson TH. Secondary aortomenteric fistulas: prostheric and paraprosthetic, The American Surgeon 47:313-321,1981.

68 Crwe PJE. Foord R. A five-year prospective study of 23.649 surgical woonds. Arch Surg 107:206-210,1973.

69 Carl GR, Ricotca JJ. Total prosthetic graftexcision and extra-anatomic bypass. In Calligaro $\mathrm{KD}$, Veirh $\mathrm{FJ}$ eds. Management of infected arterial grafts. Qtality Medical Publishing. $\mathrm{Sr}$ Louis Missouri 1994, pp 82-94.

70 Darling III RC, Resnikoff M, Kreienberg PB, Chang BB, Paty PS, Leather RP, Shah DM. Alternarive approach for management of infected aortic grafts. J Vasc Surg 25:106-112,1997.

71. Davidson $A L G$, Clark $\mathrm{C}$, Smith $\mathrm{G}$. Postoperative woundinfection: a compuret analysis. $\mathrm{Br} J$ Surg $58: 333-337,1971$.

72 Dajani AS. Bisno AL Chung KJ et al. Prevention of bacterial endocarditis: Recommandations by the American Heart Association. JAMA 264:2919-2922,1990.

73 DeNatale-RW; Crawford-ES; Safi-H.J; Coselli-JS. Graft reconstruccion to treat disease of the abdominal aorta in patients with colostomies, ileostomies, and abdominal wall urinary stomata J-Vasc-Surg, 6:240-247,1987.

74 DelWese MS, Fry WJ. Small bowel erosion following aortic resection. IAMA $179: 882-886,1962$

75 DiMusio P\%. Relly LM, Stoney RJ. Redo aortic grafring after treament of aortic graft infection. Journ Vasc Surg 24:328-337, 1996.

76 Dimarza L. Feddhaus RJ, Schuln. RD. Surgical treatment of infected aortofemoral grafts: a 15 year expericnce, I Vasc Surg 21:229234, 1987.

77 Dowghery SH, Simnons RL. Infecrions in bionic man: The pathobiology of infecrion in prosthetic dewices: Part I and II. Curr Probl Surg 19:1-314,1984.

78 Doughery SH, Simmons RL Current problems in Surgery. Surgery 19:268-318, 1992.

79) Downs AR, Lye CK, Mackean G. Graft infections in aorroiliac arterial reconstructions. Can J Sutg 26:328-329,1983.

80 Doun AR; Guman R; Fornichi M; Courbier R; Jausseran JM; Branchereau A; Juhan $C$; Chakle $N$; king $M_{i}$ Guidoin R.Etiology of prosthetic anastomotic false aneurysms: pathologic and soructural exaluation in 26 cases. Can J 5urg 3453-8,1991. 
81 Dubost C. First succesfull resecrion of an aneurysm of an abdominal aorta with restotation of the continuiry by a human arterial graft. World I Surg 62256-257,1982.

82 Dubost $C$. Allary M, Oeconomos $\mathrm{N}$. Concerning the treament of aneurysm of the stota: ablation of the aneurysm - reestablishment of continuiry by gratt of the preserved human aorta. Arch Surg 64: 405, 1952 .

83 Dunlop $M G$, Fox JN, Stonebridge PA, Clason AERuckley CV. Vacum drainage of groin wounds afrer vascular surgery: a controlled trial. Br J Surg $77.5562,1990$.

84 Dunn DA, Downs AR, Lye CR. Aortoiliac reconstrucrion for occlusive disease: comparison of end to end and end to side proximal anastomosis. Can I Surg 25.382-384, 1982.

85 Durhatm $J R$, Malone JM. Bernard VM. The impace of multiple operations onthe imporance of arterial wall cultures. J Wasc Surg 5:160-169,1987.

86 Eamshaw /J. Stack RCB, Hopkinson B. Makin G. Risk factors in vascular surgical sepsis. Ann R Coll Surg Engl 70: 139-143,1988.

87 Earashaw J/, Berridge DC, Slack RBC, Makin GS, Hopkinson BR. Do pre-operative barths with chlorhexidine reduce the risk of infection following vasculat reconstruction? Eur I] Vase Surg 3:323-326, 1989 .

88 Edwards MJ Richardson JD, Klamer TW. Management of aorric protheric infecrions. Amer ] surg 155:327-330,1988.

89 Ehrenfeld WK Prosthetic vascular graft infection. In: Hamovici $H$ ed. Vascular emergencies. New York: Appleton, 1982, pp515-525

90 Ehrenfeld WK, Wilbur $B G$, Olcon CN, Stoney R. Aurogeous rissue reconstruction in the managemen of infected prosthetic grafrs. Surgery 85:82-92,1979.

91 Ebrenteranz NJ. Antimicrobial prophylasis in surgery: Mechanisms, Misconceptions, and mischief. Infect Control Hosp Epidemial. 14: 99-106, 1993.

92 Eiswer L, Harder F. Narbenhemien. Chirurg, 68:304-309,1997.

93 Elek SD, Conen PE. The virulence of Staphylococus pyogeres for man: a study of the problem of woundinfecion. Br J Exp Parhol. 38573,1957.

94 Ellow IP, Smirh RF. Sxilagyi DE. Aorro-enteric and paraprostheric enteric firulas. Arch Surg 108:479-490,1974.

95 Ellis $H$, Gajaj $H$, George CD. Incisional heraias: when do they vecur ? Br I Surg $70: 290-291,1983$.

96. England DW, Simms MH. Recurrent aortoduodenal fistulat a final solution? Eur ] Vatsc Surg 4:427-429, 1990 .

97 Erast $C B$, Camplell $C_{*}$ Dougherry M. Sachatllo $C R$, Grifin wO. Incidence and significance of intraoperative bacteriol cultures during abdominal aorcic anevirysmecomic. Ann Surg 185:626-630,1977.

98 Evans GR, Francel T], Manson PN. Vascular prosthetic complicarions: Suces of salvage with muscle-flap reconstruction. Plast. Reconstr. Surg, 91:1294-1302,1993.

99 Fankas /C, Fichelle JM, Laurian C, Jean-Babtiste A, Gigou F, Marzellc J, Goldstein FW, Cormier JM. Long-term follow-up of positive cultures in 500 abdominal aortic aneurysms. Arch Surg 128: 284-288,1993.

100 Fenuthdes.JF, Damiao A, Almeida CH. Aortic bifurcarion grafuing for stenosing disease. In Greenhaligh RM, Hollier LH, eds. The maintenance of arterial reconstruction. Philadelphia: W.B. Saunders Co., 1991, pp 317.350.

101 Fltcher $J P_{3}$. Dryden M, Sorrell TC. Infecion of vascular prostheses. Aust-N-Z-J-Surg; $61: 432-5,1991$. 
102 Flye MW, Thompson WM. Aortic grafe-enteric and paraprosthetic-enteric fistulas. Am I Surg $146: 183-187,1983$

103 Fokin AA, Zorov SP, Verbovetskil LP. Vazhenin AV. Replacement off infected vascular prosthesis by the femoral vein. Khinugita 657-59,1991.

104 Fonter JH Berzins T, Scou HW. An experimental study of arterial replacement in the presence of bacterial infection. Surg Gynecol Obster 108:141-148,1959.

105 Frangis $F$. Thevener $A$. Conservatwe rearment of prosthetic aortic graft infection with iurrigation. Ann Vasc Surg 5:199-201,1991.

106 Fraske $\$$. Voir R. Vena femonalis superficialis in arto-iliacaler position- als autogener Gefassersatz beim tiefen Proneseninfekr geeignet? Der Chirurg 67:843-849,1996.

107 Freinsanis VE. Kozak B. Taylor LM, ca. Failure of CT scanning to diagnose arric graft infection. J Wascsurg 6:531-532,1987.

108 Freischtag JA, Moore WS. Infection in prosthtic wascular grafts. In Rurherford RB, ed. Vascular surgery, 3rd ed. Philadelphia: WB Saunders. 1989.

109 Fredmos $S G$, Lazarro RS, Spier LN, Moccio C, Tortolani AJ. A prospective randomized. comparison of Dacron and Polytetrafluorethylene aortic bifurcarion grafts. Surgery $117: 7.10,1995$.

110 Fy, RE, Fry WJ. Cholelithiasis and aorcic reconstrucrion: The problem of simulanious surgical therapy. J Vasc Surg 4:345,1986.

111 Fy WJ. Lindenauer SM. Infecrion complicating the use of plastic arterial implants. Arch Surg 94:600-609,1967.

112 Fulenuider 17, Smith RB, Johnson RW, Johnson RC, Salaam AA, Perdue GD. Reoperative abdominal surgery: a l0 year experience. Surgery 93:20-25,1983.

113 Gamet HE, Beall AC, Jordan GL, DeBakey ME. Surgical considerations of massive gastrointestinal tract hemorhage caused by aorto-duodenal fistula. Arner I Surg $105: 6-12,1963$.

114 Gaylis H. Pathogenesis of anastomotic aneurysms. Surgery 90:509-515,1981.

115 Geary KJ, Zygmund M, Tomkiewiec M, et all. Differential effects of a gram-negarive and a gram-positive infection on aurogenous and prosthetic grafts. I Vasc Surg $11: 339-347,1990$.

116 Gelaber HA, Moore W. In management of infected arterial graft. Calligaro en Veith eds, Qualiry medical publishing, inc. St Louis Missouri, 1994.

117 Glinw he H. Hallstensson S, Ohlsen L, Westivan B. Avoiding blow out of the aortic stump by reinforcenent with fibring gue. A report of two cases. Eur IVasc Surg $7: 346-348,1993$.

118 Golda fF. Vascular graft infection. Infect Dis Clin North Am. 3247-258,1989.

119 Goldswtith $H S_{2}$ de los Santos R, Vanamee P. Beatrie EJ jr. Experimental protection of vascular prosthesis by omentum. Arch Surg 97:872-878,1968.

120 Goldsone /. Effency DJ. Prevention of arterial graft infecrions. In Bernard ea: Complicarions in vascular surgery. New York. Grume and Sratron 1980.

121. Goldone 1. Moore WS. Infection in vascular prosthesis. Clinical manafestations and surgial managenent, Amer I Surg $128: 225,1974$.

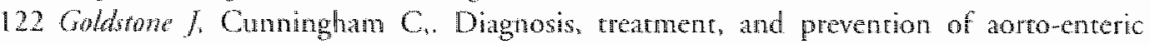
Risculas. Actal Chir Scand Suppl 555:165-172,1990.

123 Goldstone /. Moore WS. Infection in vascular prosthesis: clinical manitestations and surgical management. Amer J Surg 128: 225-233, 1974.

124 Goldtone f. Inlected prodhetic arteral grafts. In Haimovici $H$, ed. Vascular surgery 3 rd ed. Morwalk: Appleron-Lange: 1989, pp564-574. 
125 Gooding GAW, Effeney DJ, Goldsone J. The aorco-femoral Graft detection and identification of healing complicarions by ultrasonography. Surgery 89:94, 101.1981.

126 Gordon A, Conlon C, Collin J. Peto T, Gray D. Hands L. Morris P. An eight year experience of conserwative management for aorric graft sepsits. Eur J vasc Surg 8:611-616,1994.

127 Goshn PB, Rabbat $A G$, Trudel J. Why remove an infected artofemoral grafe? Can I Surg 26:330-331;1983.

128 Gozen $G$, Poggioli G. Spolaore R, Faenza A, Cunsolo A, Selleri S. Aorto enteric fisulae: spontancous and after aorto-iliac operations. I Cardiovase Surg 25:4201-426,1984.

129 Greco $K S$, Haney RA. The role of antibiotic bonding in the prevention of vasculan prostheric infections. Ann Surg 195:168-171,1982.

130 Gristina $A G$, Naylor PT,Myrvik QN. Bio-material-centered infections: microbial adhesion versus zissue integracion. In Wadstron T, Eliasson I, Holder I, Liungh A, eds. Pathogenesis of wound and biomaterial-associated infections. London: Springer Verlag. 1990 ,pp 193-216.

131 Grôschel DHM, Strain BA. Arrerial grafe infections from a microbiologist's view. In Management of infected arterial grafts. Calligaro KD, Veith FJ, eds. Qualiry Medical Publishing, Inc. St Louis Missouri. 1994, pp 3-15.

132 Hatga JR, Baldwin GN, Reich NE, ea . CT detection of infected synthetic grafts: preliminary report of a new sign. AJR 131:317 -320,1978.

133 Hallet JW, Marshall DM, Perterson TM, Gray DT, Bower TC, Cherry KJ, Glovicaki P. Pairilero PC. Grafe related complications after abdominal aortic ancurym repair: Reassurance from 36 year population based experience. J Vase Surg 25:277-284.199\%.

134 Hambracus A. A microbiologist's view on perioperative hygiene and prophylactic antibionic treatment. Acta Chir Scand Suppl 538:96-100,1987.

135. Hamory BH. Nosocomial bloodsuream and intravascular device-related infeccions. In Wenzel RP, ed. Prewencion and control of nosocomial infections. Baltimore: Willams \& Wilkins, 1987, pp 283-319.

136 Hamon R/, Wolfe JHN, Mansfield AO. Aortic prostheric infection: 50 patients reared by radical or local surgery. Br J Surg 83:654-658,1996.

137 Harnoss BM, Zullke $H$, Matura $G$, Rosenthal A. Anastomotic aneurysm. Zentralbl-Chir; $114: 169-74,1989$.

138 Harsmann S. Boquet P. Duflor E, Alouf JE, Montecucco, Papini E. Sraphylococal Alpha-toxin: A study of membrane penetration and pore formation. I Biol Chenn 264; $14978-14984,1989$.

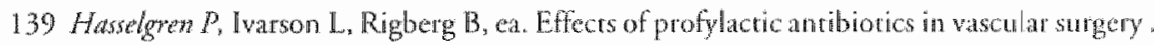
Ann Surg 200: 86-92, 1984 .

140 Hanerich A, Hirt S, Karck M, Siclati F, Wahlig H. Prevention of grafe infecrion by Bonding of Gentamycin to dacron prosthesis. J Vasc Surg 15:187-193,1992.

141 Healy DA; Keyser I 3d; Holcomb GW 3d; Dean RH; Smith BM. Prophylactic closed succion drainage of femoral wounds in patients undergoing vascular reconstruction. J-Vasc-Surg; Aug; 10(2);166-168.1989.

142 Henke PK, Bergamini TM, Garrison JR, Brituan KR, Peyton JC, Lam TM. Staphylococous epidemidis graft infection is associated with locally suppressed major histocompatibility complex class 11 and elevated MAC-I expression. Arch Surg 132:894-902,1997.

143 Hennes $N$, Sandmann W, Torsello H.W, Kniemeyer W. Grabitz K. Gefassprotheseninfekte- eine retrospektive Analyse von 99 Fällen. Dey Chirurg 67:37-43,1996. 
144 hepp W, de Jonge K, Pallua N. Late results following extramatomic bypass procedures for chronic aortoiliac occlusive disease. J Cardiovase Surg 29:181-185, 1988.

145 Herbst A, Kamme C, Norgren L, Quarfodt P, Ribbe E, Thome J. Tnfections and antibiotic prophylaxis in reconstructive vascular surgery Eur J Vasc Surg 3.303-307,1989.

146 Higgins SD, Steed DL, Julian TB, Makaroun MS, Peycanan AB, Webster MW. Management of aortoenteric praprosthetic fistulae. I Cardiovasc Surg 31:81-86, 1990.

1.47 Higgins RS, Sred DL Dummer JS, Webster MW. Culnure of inmaluminal thrombus during abdominal aortic resection: significant contamination is rare Procedings of the eastern vascular society 1990.

148 Hoffer PW, Genster \$, Haimowici $H$. Infection complicating arterial grafts. Arch Surg $90: 427,1965$

149 Holler LH, Batson RC, Cohn 1. Femoral anastomotic aneurisms. Ann Surg 191:715-720,1980.

150 /Lgenfritz FM, Jordan FT. Microbiological monitoring of aortic aneurysm wall and contents during aneurysmectomy. Arch Surg 123:506-508,1988.

151 thopoulas J7. Prerce GE. Thomas JH, Hermreck AS. Transmesocolic omentoplasty. Surg. Gynecol Obsted 157:283-4,1983

152 Jacobs M. Reul GJ, Gregoric I, Cooley DA. In-situ rephacement and extratanatiomic bypass for the treatment of infected abdominal aortic grafts. Eur J vasc Surg 5:8386, 1991 .

153 Jamieson GG, DeWeese IA, Rob CG: Infected arterial grafts. Ann Surg 181:850-852, 1975.

154 frud H, Julian OC, Dye WS, Hunter A. Complications of abdominal caortic grafts. Arch Surg 85:142-153,1962.

155 ficha DL, Reilly LM, Kucsmer LM Stoney RJ. Durability of cross-femoral grafts after aorric graft infecrion: The fate of autogenous conduits. Journ Vase Surg 22:393-407, 1995.

$156 \mathrm{Joffe} B_{3}$ Mordechay I. Conservative treatment of polytetrafluorethylene grafts infection. Vasc Surg 23:464-469, 1989 .

157 fohmon KK, Russ PD, Bair JH, Freifeld GD. Diagnosis of syntheric vascular grafr infection: comparison of CT and gallium scans. Am J Roentgenol 154:405-409,1990.

158 Jones AW. Kirk RS, Bloor $K$. The association berween aneurysms of the abdominal aorta and peptic ulceration. Gur 1 1:679-684, 1970.

159 Justich E. Amparo EG. Hricak H ea Infected aortoiliofemoral grafts: magnetic resonance imaging. Radiology. 154:133136,1985.

160 Kaebrick HW, Bandyk DF, Bergamin TW. The microbiology of explanted vasculat prosthesis. Surgery 102:756-762,1987.

161 Kuser AB, Clayson KR, Mulherin JL, ea. Antibiotic prophylaxis in wascular surgery. Ann Surg $188: 283-288,1977$

162 Karer MM. Wenk H, Sassen R. Müller G. Bruch HP. Ischärische Colitis nach gefä́sschirurgische Rekonstrucrion des Bachaortenaneurysmas. Chirurg 67:380-386, 1996.

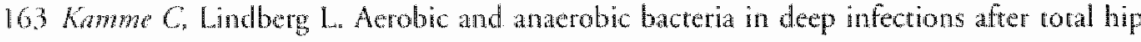
arth roplasty. Clin Othop 154:201-208.1981.

164 Kowlyme AW, Bisno AL Prostheric valve endocardiris and infections of vascular grafts. in: Bisno AL, Waldvogel FA, eds. Infections associated with indwelling medical devices. American society for microbiology. Washington D.C. pp 150-159

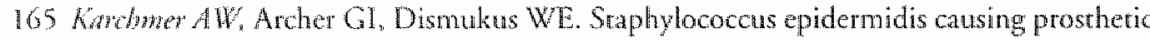
valve endocarditis: microbiologic and clinical observations as guides to therapy. Ann Intern Med 98:447-55,1983. 
166 Kasmir S, Schonfeld W, Alouf JE Konig W. Efect of staphylococous antens delra toxin on human granulocyte funcrions and platelet-accivacion-factor meabolisn. Infect lmmun 58:1653-1659,1990.

167 Kieffer E. Bahnini A, Koskas F. Ruotolo C, Le Blevec D, Plissonnier D. In sim allograft replacement of infected inframal aortic prostheric gafts. Results in foury-three patients. J Vase Surg 17:349-356,1993.

168 Koman PD, Pairolero PC, Huber JPMucha P, Wallace RB. Aortic graf-enteric fiscula. Mayo Clin Proc 55:731 -738,1980.

169 Km GE, Imperato AM, Nathan 1, Riles TS. Dilaration of symtheric grafes and juncrional anewrysms. Arch Surg 114:1296-1303,1979.

170 Kitsad PJEHM. Infectie rondom abdominale watprhesen. Ned "Tjdschr. Genesk. 134:1532-1535, 1990 .

171 Klemman KH, Towne JB, Bernard VM. A diagnostic and therapeutic approach to aorto-enteric Gistulas: dinical experience with 20 patients. Surgery $86: 868-880,1979$.

172 Klinge $U_{1}$ Prescher A, Klosterhalfen B. Schumpelick V. Entstehung und Pachophysiologie der Bauchwanddefekte. Chirurg 68:293-303,1997.

173 Kluftinger $/ L$, Lutz F, Hancock. Pseudomonas aeruginosa cytotoxin. Periplasnic localisation and inhibition of macrophages. In fect Immun 57:882-886,1989.

174 Knemeger HW, Torsello G, Hennes N, Sandmann W. Frisches homologes Arterientransplantat als aorto-iliako-femoraler Gefässersarz bei protheseninfekrion. Vasa 23:268-273,1994.

175 Kuge RM, Calia FM, McLaughlin JS, Hornick RB. Sources of contaminarion in open hart surgery. IIAMA 230:1415-8,1974.

176 Knght CD, Farnell MB, Hollier LH. Tyeatment of aortic graft infection with povidone iodine irrigation. Mayo Clin Proc 58:472-475, 1983.

177 Korz $H F$, Heyns AD, Nel CJ, Herbst CP, Badenhorst PN, Loter MG. The influence of platelet-graft interaction on plarelet survival in patients with aortobifemonal dacron grafrs. South Afr Med J 81:27-31,1992.

178 Kuestner LM, Reilly L M, Jicha DL, Ehrenfeld WK, Goldstone J, Stoney RJ. Secundary aortoenteric fistula: Contemporary outcome wirh use of excrannatomic bypass and infected graft excision. J Vasc Surg 21:185,1995.

179 Kuan JHM, Connolly JE. Succesfull management of prostheric graft infection wirh concious povidone iodine irrigation. Arch Surg $116716-720,1981$.

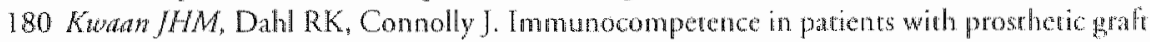
infection. I Vasc Surg 1:45 49,1984.

181 LaMmaglia GM. Fischman AJ. Strauss W, er al. Uriliry of "In-labelled human immunoglobulin $G$ scan for the derection of focal graft infection. I Vasc Surg 10:20-27,1989.

182 Landrenea MD. Rajus. Infections after elective bypass surgery for lower limb ischaemia: the influence of pre-operative transcutaneous arteriography. Surgery 90: 956-61,1981.

183 Lat JM, Mattox KL. Beall AC, DeBakey ME. Use of substinte conduits in taumaric: vascular surgery. J Trauma 17:541-6,1977.

184 Latussen J, Bille $S$, Christensen \. rransposition of the sartorius muscle in the treatment of infected vascular grafes in the groin. Eur J Vasc Surg 2:111-113.1988.

185 Lawence $P F$. Management of infected aortic grafts. Surg Clin North Am $75783-797,1995$. 
186 Lututhe Pf. Pitch RJ, Merrell Sw. Diagnosis of vascular grafe infecrions. In Bunt TJ ed. Vascular graft infections. Futura publisthing company inc. New York 1994 pp 153-171.

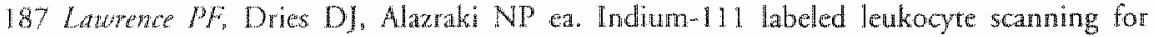
detection of prosthetic vascular graft infection. J Vasc Surg 2:165-17 1985,

18 Lautrace PF, Abo D ir. Fermorofemoral bypass with an infrascrotal perineal approach for the patient with an infected groin wound. I Vasc Surg 2:485-487,1985.

189 Lehsent T. Gruber HP Maeder N. Allenberg JR. Management of primary aortic graft infection by extra-anatomic bypass reconscruction. Eur J vasc Surg7:301-307.1993.

190 Lepantalo M. Salenius JP, Albäck A, Ylonen K, Luther $M$ and the Finmvasc studygroup. Frequency of repeated vascular surgery: A survey of 7616 surgical and endowscular Finmwasc procedures. Eur J Surg 162:279-285, 1996.

$191 \mathrm{Lew}$ MF, Schmitt DD, Edmistone CE. Sequential analysis of staphylococcal colonisation of body surfaces of patients undergoing vascular surgery. I Clin Microbial 28:664-669, 1990 .

192 Lewn BD. James EM, Welch T). Cuurent applications of duplex and color doppler ultrasound imaging: carotid and peripheral vascular system. Mayo Clin Proc. 64:1147-1157:1989.

193 Lwkwg $W G$, Greenfield LJ: Vascular prosthetic infections: Collected experience and results of treatment. Surgery 81:335-342,1977.

194 Lobbato V/. Rothenberg RE, LaRaja RD, ea Coexistence of abdominal artic aneurysm and carcinoma of the colon: A dilenma. J Vasc Surg 2:724,1985.

195 Logerfo FW, Johnson WC, Corson JD, et al. A comparison of the late patency rates of axillobilateral femoral and axillounilateral femoral grafts. Surgery 81:33-40,1977.

196 Lord JW Rossi G, Daliana M. Intra-operative antibiotic wound lavage: an attempt te climinate postoperative infection in arterial and clean general surgical procedures. Ann Surg. 185:634-641,1977.

197 Lowenzen JE, Nielson OM, Arendrup H, er al: Vascular graft infection: An analysis of sixty-wo graft infections in 2411 consecutively implanted syntheric vascular grafts. Surgery $98: 81-86,1985$.

198 Lorentzer JE, Nielson OM. Aortobifemoral bypass with autogenous saphenous vein in treatment of paninfected aortic bifurcation graft. J Vase Surg 3:666-668,1986.

199 Low RN, Wall SD, Jeffrey RB et al. Aorto-enteric fistula and perigraft infection: Evaluation with computed comografie. Radiology 175:157-162,1990.

200 Matbeth GA, Rubin JR, Mclntyre KE jr, Goldstone J, Malone JM. The relevance of arterial wall microbiology to the treament of prostheric graft infecrions J Vasc Surg $1: 750-756,1984$.

201 Mackengie R/. Buell AH, Pearson SC. Aneurysm of aortic homografe with ruprure into the duodenum. Arch Surg 77:965-969,1958.

202 Mar GT. Seow WK. Pier GB, McCXormack. JC. Thong YH. Suppression of lymphocyte and ncurrofil functions by Pseudomonas aenginosa mucoid exopolysacharide (alginate): Reversal by physicochemical, alginase, and specific monoclonal antibody treatments. Infect limmun 61:559-564,1993.

203 Malone $/ M$. Lalka $\mathrm{SG}$, Mclntyre KE, ea The necessity for long term antibioric therapy with positwe arterial wall cultures. J Vasc Surg 8:262-267,1988.

204 Malone MM, Moore WS, Campagna G, Bean B. Bacreremic infectabilicy of yascular grafts: the influence of pseudointimal incegrity and duration of graft function. Surgery $78: 211-216,1975$. 
205 Mak AS, McCarthy SM, Moss AA, Price D. Detection of abdominal worric grafic infection: comparison of CT and indum-labelled white blood cell scans. Am I Roengenol $144315-318,1985$.

206 Marin A, Copeman PWM. Aorro-jejunal fistula from rupture of Teflon graft, with sepric emboli in the skin. Br Med J 2:155-156,1967.

207 Martin-Paredero V, Busurtil RW, Dixon SM, Baker JD. Machleder H. Moore WS. Fare of aortic graft removal. Am I Surg 146:194-197, 1983 .

208 Masuda EM, Kistner RL, Ferris EB III. Long-term effecs of superficial femoral vein ligation: Thireen-year follow-up. IV Vase Surg 16:741-749,1992.

209 May AL, Darling RC. Brewster DC, Darling CS. A comparision of the use of cephalotin and oxacillin in vascular surgery. Arch Surg 115:59-59,1980.

210 McAuley $C E$, Steed DL, Websrer MW. Bacrerial presence in aortic thrombus at elecrive aneurysm resection: Is it clinically significan? An J Surg 147:322-324, 1984.

211 Mc Cann RL, Schwartz LB, Georgiade GS: Management of abdominal aortic graft complications. Ann Surg 6:729-734,1993.

$212 M c D o u g a l$ EG, Burnham S], Johnson G. Rifampicin protecrion against experimental graft sepsis. J Vasc Surg 4:5-7, 1986.

213 Mebta AI, McDowell DE, James EC. Treament of massiwe gastrointestinal hemorrage from aorto-enteric fistula. Surg Gynecol Obster 146:59-62, 1978.

214 Miller JH. Partal replacement of an infecred arterial graft by a new prosthenic polyterafluoroechylene segment: A new therapeutic option. I Vasc Surg $17,546-558,1993$.

215 Mixter RC. Tumipseed MD, Smith DJ et all. Rotational murde flaps: A new technique for covering infected vascular grafts. If Vasc Surg 9:472-478,1989.

216 Monsan JRT, Courney DG, Jones NAG, Kester R. Camabilization of a goretex aorto-heparic graft by the duodenum. $\mathbb{B r} J$ Surg 72:101,1985.

217 Moore WS, Prostheric arterial graft material. Influence on neointimal haeling and bacterial infectability. Arch Surg 115:1379-1383,1980.

218 Moore WS, Infection in prosthetic wascular graft. In Rutherford, ed. Vascular Surgery. W.B. Saunders Company, Philadelphia 1993.

219 Moore WS, Malone JM, Keown K. Prostheric arterial graft material: influence on neointmal healing and bacteremic infectibility. Arch Surg 1 15:1379-1383,1980.

220 Moore WS Infection of vascular grafts: Incidence, bacteriology and pathogenesis. In: Bermard VM, Towne JB, eds Complicarions in vascular surgery: Orlando. Grunc \& Stration, 1986, pp 483-490.

221 Moore WS, Mallone JM. Vascular infection. In Howard RJ, Simmons RL eds. Surgical infecrious diseases. 2nd ed. East Norwalk, Conn.: Applecon \& Lange, 1988, pp 591-600.

222 Moran KT, Jewell ER. Local antiseptic treatment of infected prosthetic vasctatar grifts in the groin. Br I Surg 75:1037-1038,1988.

223 Momis GE. Friend PJ. Vassallo DJ, et all. Antibiotic irrigation and conservative surgery for major aorric graft infection. I Vasc Surg 20:88-95, 1994.

224 Muray SP, Goldstone T. Dagnostic advances. In Calligaro KD, Veith Ho eds Management of infecred arterial gratt. Qualicy Medical Pubfishing, Inc. St Louis, Mussouri, 1994. pp $44-53$.

225 Muller-KM. Dasbach-G. The pathology of vasculat grafts. Curr-Top-Pathol. 86: $273-306,1994$ 
226 Najafi H, Javid H, Dye WS, Management of infected arterial implants, Surgery $65.539-550,1969$.

227 Naylor AR, Clark S, London NJM. Sayers RD, Macpherson DS, Barrie WW, Bell PRF, Treatment of major aortic graft infection: Preliminary experience with cotal graft excision and in siru replacement with rifampicin bonded prosthesis. Eur I Vasc Surg $9: 252-256,1995$.

228 Netelstery, Lacroix $H$, Suy $R$. The superficial femoral vein as aurogenous conduit in the treament of prostheric arterial infection. Ann Vasc Surg 7:556-560,1993.

229 Nevelster A. Lacroix H, Suy R. Autogenous reconstruction with lower extremity deep veins: An alternative treatment of prosthetic infection after reconstructive surgery for aortoiliac disease. J Vasc Surg 22:129-134,1995.

230 Nevelsten A, Wourers L. Suy $\mathbb{R}$. Aortofemoral reconstruction for aorto-iliac occlusive disease: A 25-year survey. Eur ] Vasc Surg 5:179-186,1991.

231 Nielsen OM, Noer HH, Jorgensen LG, Lorentzen JE. Gentamycin beads in the rreatment of localised vascular graft infection- Long rem resules in 17 cases. Eur $;$ Vasc Surg $5: 283-285,1991$.

232 Noyzz L, Newelsteen A, Suy R. Devos P. Mortelmans L. Value of indium-111-labeled leukocytes scintigraphy in parlents after arterial reconstructive surgery. Int Angiol $5: 79-82,1986$.

233 OBrim $T$; Collin J. prosthetic vascular graft infecrion: Br J Surg 79: 1262-1267,1992.

234 Ochsner JL, Cooley DA, DeBackey ME. Associated intra-abdominal lesions encountered during resection of aortic aneurysms: Surgical considerarions. Dis Colon Rectum $3: 485,1960$.

235 OHara PJ, Borkovski GP, Hertzer NR O'Donovan PB, Brigham SL, Beven EG. Natural history of periprosthetic air on computerized axial tomographic examination of the abdomen following abdominal aortic aneurysm repair. I Vasc Surg 1:429-433,1984.

236 OHara P. Herzer NR. Beven EG, Krajewski LP. Surgical management of infected abdominal aorric grafts: Review of a 25-year experience. J Vasc Surg 3:725-731,1986.

237 OMara CS. Embembo AL. Paraprosthetic-enteric fistula. Surgery 81:556-566,1977.

238 OMara CS, Williams GM. Ernst CB. Secondary aoroenteric fistulae: a 20 year experience. Am J Surg 142:203-207,1981.

239 Olafsom PA, Auffermann W, Higgins CB, Radahie GN, Tavares $N$, Sroney Rl. Diagnosis of periprosthetic graftinfection by MRI. J Vasc Surgery 8:99-105,1088.

240 Olofson PA, Rabahic GN, Marsumoto K, Ehrenfeld WK, Ferrell LD, Goldstone J, Reilly L.M, Stoncy RJ. Histopathological chanacteristics of explanted human prothetic arterial grafts: limplications lor the prevention and management of graft infection. Eur J Endovase Surg $9: 143 \times 151,1995$.

241 Ondor J. Beaconsfield P. Thrombosis of the aorcic bifurcation reated by resection and homograft replacement: report of five cases. Arch Surg 66:365 374, 1953.

242 Owiel $K$. Ricota J. Adams JT, wa. Management of cholelichiasis in patients with abdominal aortic aneurysm. Ann Surg 198:717,1983.

243 Pakke W. Hansen $H$. Graft-enteric fisculas and erosions. Surg Gynecol Obstet $161: 161-164,1985$.

244 labst TS, Bernhard VM. Mclntyme KE jr, Malone JM. Gascromrestinal bleeding after aortic surgery. The role of laparotomie to rule out aorto-enteric fistula. Eur J Vase Surg $8: 280-285.1988$. 
245 Padberg FT, Smith SM. Eng RHK. Optimal method for culturing vascular prosthetic grafts. I Surg Res 53:384-390,1992.

246 Pasmanelli $G$, Freyrie $A$, Preda P, Curt T. DAddato M, Laschi R. Healng of prostheric arrerial grafts. Scanning Microse 4:351-362,1990.

247 Peck J], Eiderniller LR. Aortoenteric fistulas Arch Surg 127:1191-1194,1992.

248 Perdue GD, Smith RB, Ansley JD, Constantino MR. Impending aortic haemorthage: the effect of early recognition on improved ourcome. Ann Surg $192: 237243,1980$.

249 Perler BA. Vander Kolk CA. Dufresne CR, Williams GM. Can infected prostheric grafrs be salvaged with fotational muscle flaps? Surgery 11030-34,1990.

250 Pery MO. Infection in vascular surgery. In Davis JM, Shires GT, eds. Priciples and management of surgical infecrions. Philadelphia: WB lippincort, 1991, pp 371-382.

251 Pier GM, Marchews WJ Jr, Eardley DD. Immunochemical characterizarion of the mucoid exopolysaccharide Pseudomonas aeruginosa. J Infect Dis 147:484-503,1983.

252 Piomows bi J/. Bernard VM. Management of wascular grafe infections. In: Bernard VM. Towne JB, eds Complications in vascular surgery. St Louis: Quality medical publishing Inc. 1991 pp: $235-258$.

253 Pinch R/, Lawrence PF. Natural history of graft infections In Bun TI) (ed) Vascular graft infections. Armonk, Futura publishing, 1994 pp $31-41$.

254 Pate $G$. Hollier LA, O'Brian $\mathbb{P}$, et al. Recurrent ancurysms and late vascular complications following repair of abdominal aorric aneurysms. Arch Surg 120,590,1985.

255 Polak/F, Donaldsen MC, Whirremore AD, et al. Pulsarive masses surrounding wascular prosthesis: Real time US color How inaging Radiology 170:363-366,1989.

256 Polak JF, Donaldson MC, Whittemore AD, ea Pulsarive masses strounding vascular prosthesis: real time US color flow imaging. Radiology. 170:363-366, 1989

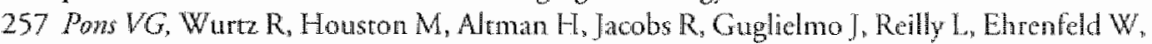
Stoney R. Vascular graft infecrions: A 25-year experience of 170 cases. J Vasc Surg $13: 751-752,1991$.

258 Popows $y$ f. Singer S. Infected prosthetic grafts. Local therapy with graft preservation. Arch Surg 115:203-5, 1980.

259 Pricolo VE, Potenn F, Soderberg CH. Etfect of perigraft seroma fluid on fibroblasts in vitro. Ann yasc Surg 5:462-466, 1991 .

260 Quick CRG, Vassallo DJ, Colin JF, Heddle RM. Coserwative trotment of major aonic graft infection. Eur J Vase Surg 4:63-67,1990.

261. Qumone-Baldrich WJ, Hernander J], Moore WS. Long tem resulis following surgical management of aorric graft infection. Arch Surg 126,507-511,1991.

262 Qunones-Baldrich WJ. Gelabert HA. Aurogenous tissue reconstruction in the management of aortoliofemoral graft infection. Ann Vasc Surg.4223-228, 1990.

263 Quarford PC. Reilly LM, Mark AS, et al. Computerized romographic assesment of graft incorporation after aortic reconstruction. Amer ] Surg 150:227-321,1985.

264 Raphad $p$, Cogbill-TH: Dunn-EL; Strutr-PJ; Fraga-MJ. Rourine invasive hemodymanic monitoring does nor increase risk of aortic graft infection. Heart-lung. 22:12]-4, 1993 .

265 Reilly LM, Alman H, Lusby R, Kersh RA, Ehrenfeld WK, Stoncy $\mathbb{1}$ ]. Late results Following surgical managenent of vascular graft infecion. J Vasc Surg 1:36-44,1984.

266 Reilly LM, Ehrenfeld W, Goldstone I, Stoney R. Gastrointestinal tract involvement by prosthetic grafo infection. Ann Surg 202:342-348,1985.

267 Reilly LM, Stoney RJ. Goldstone I, Ehrenfeld W/K. Improved management of aortic graft infecrion: The influence of operarion sequence and saging. J Vase Surg 5:421-431,1987. 
268 Reilly DT, Grigg MJ, Cunningham DA, et al. Vascular graft infection: the role of indium scanning. Cur J Vasc Surg 3:393-397, 1989.

269 Reirma $J B^{2}$ de Groot RRM. Aantal opnamen voor aneurysma abdominale aorta scijgt: Sarnenwerking tussen de Nederlandse Hartstiching en de SIG, een epidemiologische verkening. Signet 4:5-7, 1993 .

270 Ricei MA. Mehran R, Christou NV, Mohamed F, Graham AM, Symes JF. Species differences in the dearance of Staphylococcus aureus bacteremia. J-Invest-Surg 4(1), 1991 , Pp $53 \% 8$.

271 Ricci MA, Mehran RJ, Persikas D, Mohamed F, Guidoin R; Marois Y, Christou NV, Graham A. Symes JP. Species differences in the infectability of vascular grafis. J-Invest-Surg: $4(1) 1991$, pp $45-52$

272 Ricota y, Faggioli $G$, Stella $A$ et all. Total excision and extra-anatomic bypass for aortic graff infecrion. Amer J Surg 162: 145-149,1991.

273 Robinson $/ A$, Johansen K. Aortic sepsis: is tehere a role for 'in situ' graft reconstruction? ] Vasc Surg 13:677-684,1991.

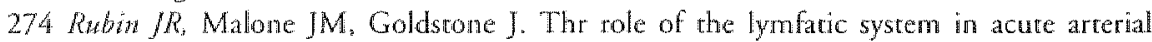
prostheric gralt infections. I Vasc Surg 2:92-98,1985.

275 Rutherford RB. ed, Vasculat surgery 2nd edicion 1984. Saunders company, London.

276 Salswan G. Perioperative infeccion prophylaxis in vascular surgery: a randomized prospectiwe study. I Thorac Cardiowasc Surg. 31:239-242, 1983.

277 Samzsoy RH, Gupta SK, Scher LA, Veirh FI. Fallibility of intraoperative Gram stain in the diagnosis of wascular infecrion. Angiology 680-684,1982.

278 Sanson RH, Veth $1 \mathrm{~J}$, Janko GS. A modified classififcation and approach to the management of infections involwing peripheral arterial prosthetic grafts. I Vasc Surg 8:147-153,1988.

279 Santin $C$, Speziale $\mathrm{F}_{\mathrm{r}}$ Massimi GJ. Preliminary of a complete study prococol on synthetic vascular graft healing and its complications. Int Angiol 11:21 1-217,1992.

280 Santina C, Baiochi P, Venditri M, Brandimarte C, Tarasi A, Rizzo L, Speciale F, Fiorani P, Serrat P. Aorto-femoral grafr infections: a clinical and microbiological analysis. Journal of infection $27: 17-26,1993$.

281 Sanuge LR, Berger KE, Wood SJ. Interspecies healing of porous arteriall prosthesis. Arch Surg 109:698-705, 1974.

282 Sibanzy. $H$. Chiang K, Mabrouk M. Peirce EC. Use of lower extremicy deep veins as arteriall substitures: Functional status of the donor leg. J Vase Surg 14:624-627,1991.

283 Schellack /. Steward MT, Smith III RB, Perduc G, Salam A. Infected aortobifemoral prosthesis-at dreaded complication. The american surgeon 54:137-141.1988.

28.4 Sobrilack J. Salam A. Abouzeid MA, Smith RB 3d; Stewart MT; Perdue GD. Femoral anrstomoricaneurysms: a continuing challenge. J Vasc Surg 6:308-17,1987

285 Sownit DD, Bandyk DF, Pequec AJ, Towne JB. Bacterial adherence to vascular prosthesis: a decerminan of graft infecrivity. Vasc Surg 3:732-740,1986

286 S. Wmit DD, Seabrook GR, Bandyk DF, Towne JB. Graft excision and extranatomical revascularisation: The reatment of choice for the septic aorric prosthesis. J Cardiovasc Surg $31: 327-330,1990$.

287 Shwentawn SC, Gardner p. Shillito J. Infection of cerebrospinal fluid shunts: Epideniology, dinical manifestations, and therapy. J Infect Dis 131:543-551,1975. 
288 Schulnan ML, Badhey MR, Yatco R, Supeficial femoral-popligeal vens and reversed saphenous veins as primary femoropopliteal bypass grafrs: $A$ randomized companative study. I Vasc Surg 6: 1-10,1987.

289 Sobwant $J A$, Powell TW, Burmham S1. Johnson jr G. Culture of abdominal nortic aneurysm contenss. Arch Surg 122:777-780,1987.

290 Scobie $K_{n}$ McPhail N, Barber G. Bacteriologic monitoring in abdominal aortic surgery. Can ISurg 22:368-374,1979.

291 Seabrook GR, Schmit DD; Bandyk DF; Edmisron CE; Krepel C]; Towne JB. Anastomotic femoral pseudoaneurysm: an invesrigation of occult infecrion as an eriologic factor. J Vasc Surg 11:629-34,1990

292 Sedwitz MM, Davis R], Precorius HT. Indium 11 -labeled whice blood cell scans after vascular prostheric reconstruction. I Vasc Surg 6:476-481.1987.

293 Sedwitw MM, Hye-RI. StabileBB. The changing epidemiology of psetdoaneurysm. Therapeutic implications. Arch-Surg 123:473*6,1988.

294 Seger J $M$, Wheeler JR Gregory RT, Snyder SO, Gayle RG. Autogeous grafieplacement of infected prothetic grafts in the femoral position. Surgery $93: 3942,1983$.

295 Shah DM, Buchbinder D, Leather RP, Corson J, Karmody AM. Clinical use of the seromuscular jejunal patch for protection of the infected aortic stump. Am I Surg $146: 198-202,1983$.

296 Sharp Wy, Hoballah J, Mohan CR, Kresowik TF, Martinasevic M. The management of the infecred aortic prosthesis: A current decade of experience. J Vasc Surg $19.844-850,1994$.

297 Shaw RS, Bane AE. Management of sepsis complicating atterial reconstructive surgery. Surgery 53:75-86, 1963.

298 Sherris $/ C$, Plorde JJ. Staphylococci. In Sherris JC. Champoux J] Neidhardt CC, eds. Medical microbiology: An intraducrion to infectious diseases. New York: Eisevier Science, 1990, pp 275-289.

299 Shoevfeld NA, Connolly R, Ramberg K, Valeri CR, Eldrup-Jorgensen I, Callow AD. The systemic acrivation of platelers by Dacron grafts. Surg Gynecol Obster 166:454-457,1988.

300 Sienweyda C, Skotnicki SH, Barentsz JO, Heystraten FMJ. Anastomotic aneurysms- an underdiagnosed complication after aortomiliac reconstructions. Eur I Vasc Surg $3: 233-238,1989$.

301 Silwa $f$. Harvey W. Detection of infections with gallium-67 and scintigraphic imaging. I Infect Dis 130:125-131,1974.

302 Simpson $A$, Astin J. Peck M. Diagnosis of an abdominal aorric graft abces by combined ultrasonography and scintigraphy. Clin Nucl Med 4:338-340,1979.

303 Slaughter L, Morris JE, Starr A. Prostheric valwular endocarditis: A 12-year revicw. Circulation 47: $1319-1325,1973$.

304 Smead W. Vaccaro P. Infrarenal aortic aneurysmecomy, Surg Clin North Am 63:1269-1292,1983.

305 Smith RB IIT. Arthur B.Voorhes, jr: Pioneer vascular surgecon. I Vasc Surg 18: $341-348,1993$.

306 Smith KR, Beals PD. Kingsbury KR, Hasendever NE: Observations on Sraphylococcus albus septicenia in mice and men. Arch intern med $102.375-88,1958$.

307 Snyde SO, Wheeler JR, Gregory RT, Gayle RG, Zirkle I'K. Freskly harwested wenous homografts as arterial conduirs in infected fields. Surgery 101:283-29 1, 1987. 
308 Sompl IM, Schreiber H; Byramjee AM. The rarionale for incidental cholecystecromy during major abdominal vascular surgery. Am I Surg; 57: 579-81, 1991 .

309 Sormen $S$. Lorentaen JE. Aseptic prosthesisinfection caused by Dacron allergy or foreign bodyreaction?" Treatment of 2 cases by replacement with PTFE prosthesis. Ugeskr-Laeger 29:152:P3260-1,1990.

310 Somwrai VS, Lim Sue S, Mann WK. Batson RC. Pseudointima formation in woven and Knitred dacron grafts. ICardiovase Surg 30:808-816,1990.

311 Sattimdi VS, Yao JS, Flinn WR, Batson RC. Incimal hyperplasia and neointima: An ultrastructural analysis of thrombosed grafts in humans. Surgery 93:809-817,1983.

312 Spartera $C$. Morertini $G$, Perrassi $C$, er al. The role of MRI in the evaluation of aorric grafe healing, perigraft huid collection and graft infection. Eur ] Vasc Surg 4:69-73,1990.

313 Speziate F, Rizzo L, Sbarigia E, Giannoni MF, Massucci M, Maraglino C, Santoro E, Fionan 1 . Bacterial and clinical criteria relating to the outcome of patients undergoing in sicu replacement of infected abdominal aortic grafts. Eur I Vasc Endovasc Surg $13: 127-133,1997$.

314 Statgras REM, Harvey DP, Ferrante A, Nandoskar M, Allison AC, Introducrion of tumor necrosis factor (TNF) and interlleukin-1 (IL-1) by Psudomonas aeruginosa and exotoxin a-induced suppression of lymphoproliferation and TNF, lymphotoxin, gamma interferon, and IL-1 production in human leucocytes. Infect Immun 60:3162-3168,1992.

315 Sterperti $A V$, Hunter W], Schultz RD, Farina $C$. Healing of high-porosiry polytetrafluoroethylene arterial grafts is influenced by the nature of the surrounding tissue. Surgery 111:677-682,1992.

316 Stoll WM. Surgery for intra-abdominal lesions associated with resection of aortic ancurysms. Wis Med J 65:89,1966.

317 Staney RJ Reilly LM. How should we treat Infected grafts? In: Greenhalgh RM, Jamieson CW, Nocolaides AN, eds. Vascular Surgery: Issues in current practice. London: Grume\& Stratton, 1986, pp 309-314.

318 Stoney RJ, Albo RJ, Wylie E). False aneurysms occurring after arterial grafring operations. A.m I Surg 110:153-161,1965.

319 Sining ST. Cholelithiasis and aortic reconstruction. J Vasc Surg 1:664,1984.

320 Stgetman $B$, In witro adherence of bacteria to prosthetic vascular grafts. Infection. $10: 9,1982$

321. Sudtron R/, Litrooy FN, Hunt TK ca Laparotomy as a precipitating factor in the ruprure of intratabdominal aneurysms. Arch Surg $115: 299,1980$.

322 Sweeney MS, Gadace TR. Primary aorto-duodenal fistula: manifestation, diagnosis and teatuent. Surgery $96: 492-497,1984$.

323 Szidgeg ED, Smirh RF, Elliow IP, et al. Anastomotic aneurysms after vascular reconstruction: Problems of incidence, etiology and treatment. Surgery 78:800-816,1975.

324 Sidtugy ED. Smith RF, Elliott JP, Vandecic MP. Infection in arterial reconsmuction with syntheric grafts. Ann Surg 176:321-333,1972.

325 Szildagy $E D$, Elliotr $J P$, Berguer R, Coincidental malignancy and abdominal aortic aneurysm. Arch Surg 95:402,1967.

326 Sxilagy ED, Elliout JP. Smith RF, Reddy DJ, McPharlin M. A thiry year survey of the reconstructive surgical treament of aortoilac ocdusive disease. I Vasc Surg $3: 421-436,1986$

327 Thom a JH, McCroskey BL, lliopoulos JI, Hardin ca, Hemreck AS, Pierce GE. Aorto-iliac reconstruction combined with non-vascular operanions. Am J Surg 146:784-787, 1983. 
328 Thomas JH. Abdominal aoric aneurysmormaphy combined with biliary or gastrointestinal surgery. Surg-Clin-North-Am: 69:807-15, 1989.

329 Thomas WEG, Baird RN. Secundary aorto-nteric fistulasi towards a mone conservarive approach, Br J Surg 73:875-8,1986.

330 Thompknis $W \mathrm{C}$, Chavez $\mathrm{CM}$, Conn $\mathrm{JH}$, ea Combining intra -abdominal aratial grafring with gastrointestinal or biliary tract procedures. Am I Surg 126:598,1973.

331 Thompson BW, Read RC, Campbell GS. Unintected false aneurysms after arrerial reconstruction with prosthetic grafts. An j Surg 138:920-923, 1979).

332. Tizhnus HW, Terpstra OT, de Snir P, wan Urk H, Veen HF. Diagnosis and mantagement of grafe enteric fistulae. Br] Surg $75.915-916,1988$.

333 Tobin $K D$. Aortobifemoral perignaft absces: treament by percutaneous carherer drainage.] Vasc Surg 8:339-343, 1988.

334 Tolkefson-ED: Bandyk-DF; Kabnick-HW; Seabrook-GR; Towne-JB. Surfilee biofilm disruprion. Enhanced recovery of microorganisms from wasculat prostheses. Arch-Surg. 122: $38-43,1987$.

335 Torsello $G_{*}$ Sandmann W. Gehrt $A$, Jungblut RM. In sicu replacement of infected vascular prosthesis with rifampicin-soaked vascular grafts: early results. I Vasc Surg 17:168, 1993.

336 Towne JB, Seubrook GR, Bandyk D. Freischlag JA, Edniston CE. In situ relacement of arterial prosthesis infected by bacterial biofilms: Long-term follow-up. J Vasc Surg 19. $226-235,1994$.

337 Trout II HH, Kozloff L, Giordano JM. Prionicy of revascularisation in patients with graft enteric fistulas, infected arteries, or infected arterial prosthesis. Ann. Surg. 199:669, 1984.

338 Tseng LNL, Haverlag R, Marguer RL, Jeekel I. Intra abdominale adhesies: parhogenese an preventie. Ned Tijdschr Heelk 4:107-110,1996.

339 Thrnipsed WD, Berkoff HA, Detmer DE, Acher CW, Belzer FO. Arterial graft infections: Delayed $v$ immediare vascular reconstruction. Arch Surg: 118:410-414,1983.

340 Umpleby HC, Briton DC, Turnbull AR. Secondery arterio-enteric fituba a surgical challenge. Br J Surg 74:256-259,1987.

341 Wan dea Akker $P$, Brand $\mathrm{R}$, Van Schilfgarde $\mathrm{R}$, van Bockel JH, Terpscra JL. False aneurysms afrer prosthetic reconstructions for aortoliac obstructive disease. Ann Surg $210: 658-666,1989$.

342 Van des Akkex P, wan Schilfgande $R$, Brand $R$, wan Bockel JH. Terpstra lL. Long-tom results of prosthetic and non prosthetic reconstruction for obstructive aor towiliac discense. Eur J Vasc Surg 6.53-61, 1.992.

343 Van Baden JM, Kluir AB], Maas J, Terpstra th, van Bodkel H. Diagnosis and therapy of artic prothetic fistulas: a trend over a 30-year experience. Br I Surg 83:1729-1734, 1996.

344 Vandenbronde-Grands, CMJE Meticilline-resistente Staphylococcus epidernidis NTvG $140,138,1996$.

345 Van Homberck FI van Knippenberg LA, Niessen MC, wan Grictuysen AI. Wound infection aferer antrial surgical procedures. Eur J Vasc-Surg; 6; 494-8, 1992.

346 Vaned WW. Combining abdominal arric aneurysmecromy with gastrointestinal or biliary surgery. An Surg 54:290,1988.

347 Verbragh HA, Corpora aliena. Ned Tijdsch Heelk 2:81-84,1993.

348 Vogelasng RL, Limper JD, Yao JS. Detection of prosthetio vasclar complifations: Comparision of CT and Angiografie. AJR 148:819-823,1987.

349 Vollmat JF, Kogel H. Aorto-nteric fistulas as postoperative complicauion. J Cardiovase Surg 28:479-484, 1987 . 
350 Volmar fF. Reoperations of the abdominal aorta and pelvic arreries. Langenbecks-Arch-Chir-Suppl-Kongressbd; 1991; P $514-518$.

351 Voomowe $R$, Moll FL, Bast T]. The Primary aortoenteric fistula in The Netherlends - the unpublished cases. Eur J Vasc Endovase Surg 11:429-431,1996.

352 Watkefield TW, Pierson CL, Schaberg DR, ea Artery, periarterial adipose tissue, and blood microbiology during vascular reconstructive surgery: P'erioperative and early postoperative observations. J Vasc Surg 11:624-628, 1990.

353 Watker Wh, Cooley, DA, Duncan JM, Hallman GL, Otr SA, Reul GJ. The management of aortoduodenal fistula by in situ replacement of the infected abdominal aortic graft. Ann Surg 205:727-732,1987.

354 Weber $7 R$, et all. Focal infection of aorto-femoral prosthesis. Surgery 79.310-312,1976.

355. Wengrowitz M, Spangler S; Martin LF. Sonication provides maximal recovery of staphylococcus epidermidis from slime-coared vascular prostherics. Am J Surg 57:161-4,1991.

356 White JV, Freda BA, Kozar R. Does bacteremiac pose a direct threat to synthetic vascular graft? Surgery 102:402-408,1987.

357 White $J V$, Nessel CC, Whang K. In Calligaro KD, Veith $\mathrm{FJ}$. eds, Management of infected arterial grafts. Qualty Medical publishing, Inc. St Louis, Missouri, 1994. pp 25-41.

358 Williams RD, Fisher FW. Aneurysm contents as a source of graft infection. Arch Surg $112: 415-416,1977$.

359 Willians $L R$, Flinn WR, Yao JS, et al. Extended use of computed tomografie in the management of complex aortic problems: a learning experience. J Vasc Surg 4:264-271,1986.

360 Willamson MR, Body CM, Read RC, et al." In-labelled leucocytes in the detection of rosthetic vascular graft infections. Am J Roentgenol 147:173-176, 1986.

361 Wohron $A H$, Katup HA, Mc Donald K. Ultrasound of arterial graft surgery complications. AJR 133:869-875,1979.

362 Wooster $D L$, Louch $R E$, Krajden 5 . Intraoperative bacrerial contamination of vascular grafts: a prospecrive study. Can J Surg 28:407-409, 1985.

363 Wright D/, Ernst CB; Evans JR; Smith RF; Reddy DI; Shepand AD; Elliott JP Jr. Ureteral complicarions and aortoiliac reconstruction. I Vasc Surg; 11:29-35, 1990.

364 Yoshar $\not J$, Baxter JC. Burnard RJ ea. Ulrrasonic investigation of infected vascular prosthesis. Int Surg. 64:51-53,1979.

365 Yexger R MoConnell D, Sasui T Verto R. Aortic and peripheral prosthetic graft infection: Differential management and causes of mortality. Am J Surg 150:36-43, 1985.

366 Veager RA, Moneta GL, Taylor LM. Harris EJ, McConnel DB, Porter JM. Improwing survival and limb salvage in patients with aortic graft infection. Amer I Surg $159: 466-469,1990$.

367 Yeager $R A$, Porter $\int \mathrm{M}$. Basic daca underlying clinical decisionmaking in vascular surgery. Ann Vasc Surg 6:485-491,1992.

$368 \mathrm{Yeager} R$, Porter JM. The case against the conservatiwe nonresectional management of infected prostheric grafts. Advances in Surgery 29:33-39, 1996.

3692 moneli W. Widner AF. In vitro-tests to predict afficacy of antibiorics in a foreign body infection animal model. In: Waldström T, Eliasson I, Holder I, Ljung A, eds. Pathogenesis of wound and biomaterial-associated infections. London: Springer Verlag 1990. pp $519-523$ 


\section{Curriculum vitae}

Marcel Gerardus Maria Hubertus Barwegen werd geboren in Heerlen op 17 maart 1945. Het middelbaar onderwijs volgde hij aan het St Bernardinus college te Heerlen. Het doctoraal examen werd in april 1969 aan de Rijksuniversteit te Utrecht behaald, waana hij in 1971 tot arts werd bevorderd. Hiema werd de militaire dienstplicht vervuld. In deze periode was hij tevens huisarts in Utrecht. De chirurgische opleiding vond plaars in het toenmalige Wilhelmina Gasthuis verbonden aan de Universiteit van Amsterdam van 1973 tot 1979. (opleider Prof dr R.J.A.M. van Dongen) Vanaf 1979 tor 1985 was hij als wetenschappelijk hoofdmedewerker verbonden aan de afdeling Heelkunde sectie Vaatchirurgie van het Academisch ziekenhuis van de Universteir van Amsterdam, waarna hij zich op 1 januari 1985 als chirurg vestigde in het St Maartens Gasthuis te Venlo. 


\section{Dankwoord}

Het tot stand komen van dit proefschrift was alleen mogelijk dankzij de hulp van vele anderen.

In de eerste plaats komt veel dank toe aan mijn overleden ouders die mij voldoende vrijheid lieten om mijn eigen weg te volgen maar mij daarbij wel in de juiste richting wisten te leiden.

Dank ben ik verschuldigd aan de vele leermeesters tijdens mijn opleiding tor arts aan de Rijksuniversiteit te Utrecht en in de periode daarna als militair arts en als huisarts. De herinnering aan de bezielende begeleiding van Frits ten Care, helaas te vroeg overleden, is onuitwisbaar.

Tijdens mijn opleiding tor chirurg aan de Universiteit van Amsterdam mocht ik genieten van weel uitstekende leermeesters.

Prof dr R.J.A.M van Dongen introduceerde mij niet alleen in de vaatchirurgie, maar hij leerde mij ook de kneepjes van het vak en hij gaf mij de gelegenheid en her vertrouwen om dir vak vele jaren op hoog niveau re beoefenen als waarnemend hoofd van zijn afdeling, aanvankelijk in het Willhelmina Gasthuis en later in het AMC. Tijdens deze periode ontstonden mijn eerste inzichten in de ernst van de problematiek van de diagnostiek en behandeling van geïnfecteerde vaatprothesen.

Veel dank ben ik verschuldigd aan alle andere mede-opleiders, zoals de toenmalige mede-stafleden, assistenten en collegae die ik evenals de patiënten, waarvan men immers het meeste leert, niet alle bij name kan noemen.

De overgang naar Venlo was niet gemakkelijk maar bracht weer vele nieuwe uitdagingen die ik niet licht zal vergeten. De chirurgische opleiding was uiteindelijk de directe anleiding voor her tor stand komen van dexe studie. Deze plaats biedt mij de gelegenheid om allen te bedanken die in welke worm dan ook aan deze opleiding bijdrocgen: staff, assistenten, directie en personeel en zeker niet op de laatste plats de leden van de maatschap chirurgie. Een laarste zer in de goede richting kreeg ik wan de collegae Koopal en Kootstra, die ik daarvoor oprecht will danken. Dit proefschrift kwam tot stand onder de bezielende leiding van Prof dr P.J.E.H.M. Kitslaar: Beste Peter, zonder jouw kritische en stimulerende invloed had ik het niet voor elkaar gekregen. Je was altijd voor mij bereikbaar en jouw optimisme, werklust, doorzerringsvermogen en steun gaven mij op moeilijke momenren weer de impuls die ik nodig had.

Een belangrijke bijdrage werd geleverd door F.Th.P.M. van der Linden. Besre Fred, jij hebt de eerste basale gegevens verzameld, waardoor een belangrijk deel van het geestelijk eigendom aan jou toekomt. 
Tenslorte will ik mijn gezin danken. Door de aard van mijn beroep was ik (te) vaak niet thuis. In mijn taak als vader ben ik regelmarig te kort geschoten. $\mathbb{k}$ dank jullie voor alle begrip daarvoor en voor de steun die ik alcijd van jullie kreeg.

Lieve Marianne, zonder jouw uithoudingsvermogen, begrip en steun was het nooir gelukt.

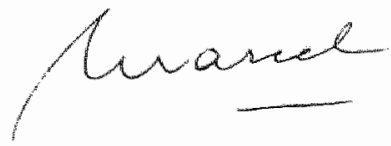

